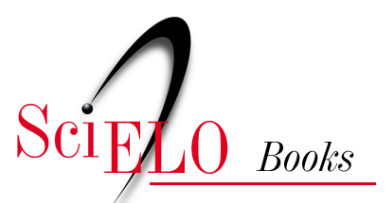

\title{
Injustiça ambiental e saúde no Brasil o Mapa de Conflitos
}

\author{
Marcelo Firpo Porto \\ Tania Pacheco \\ Jean Pierre Leroy \\ (orgs.)
}

PORTO, M.F., PACHECO, T., and LEROY, J.P., comps. Injustiça ambiental e saúde no Brasil: o Mapa de Conflitos [online]. Rio de Janeiro: Editora FIOCRUZ, 2013, 306 p. ISBN 978-85-7541-576-4. https://doi.org/10.7476/9788575415764.

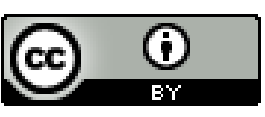

All the contents of this work, except where otherwise noted, is licensed under a Creative Commons Attribution 4.0 International license.

Todo o conteúdo deste trabalho, exceto quando houver ressalva, é publicado sob a licença Creative Commons Atribição 4.0. 


\section{Injustiça Ambiental e Saúde no Brasil \\ O MAPA DE CONFLITOS}




\section{FUNDAÇÃO OSWALDO CRUZ}

\section{Presidente}

Paulo Gadelha

Vice-Presidente de Ensino, Informação e Comunicação

Nísia Trindade Lima

\section{EDITORA FIOCRUZ}

Diretora

Nísia Trindade Lima

Editor Executivo

João Carlos Canossa Mendes

Editores Científicos

Carlos Machado de Freitas

Gilberto Hochman

Conselho Editorial

Claudia Nunes Duarte dos Santos

Jane Russo

Ligia Maria Vieira da Silva

Maria Cecília de Souza Minayo

Marilia Santini de Oliveira

Moisés Goldbaum

Pedro Paulo Chieffi

Ricardo Lourenço de Oliveira

Ricardo Ventura Santos

Soraya Vargas Côrtes 


\section{Injustiça Ambiental e Saúde no Brasil O MAPA DE CONFLITOS}

Marcelo Firpo Porto

Tania Pacheco

Jean Pierre Leroy

Organizadores

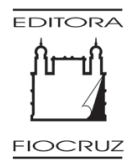


Copyright (C) 2013 dos autores

Todos os direitos desta edição reservados à

Fundação Oswaldo Cruz/Editora

Capa, projeto gráfico e editoração eletrônica

Fernando Vasconcelos

Revisão

M. Cecilia G. B. Moreira e Myllena Paiva

Normalização de referências

Clarissa Bravo

Catalogação na fonte

Instituto de Comunicação e Informação Científica e Tecnológica

Biblioteca de Saúde Pública

P853i Porto, Marcelo Firpo (Org.)

Injustiça ambiental e saúde no Brasil: o Mapa de

Conflitos. / organizado por Marcelo Firpo Porto, Tania

Pacheco e Jean Pierre Leroy. Rio de Janeiro: Editora

FIOCRUZ, 2013.

306 p. : il. ; tab. ; graf.

ISBN: 978-85-7541-434-7

1. Impacto Ambiental. 2. Vulnerabilidade Social.

3. Fatores Socioeconômicos. 4. Exploração de Recursos

Naturais. 5. Iniquidade Social. 6. Riscos Ambientais.

7. Brasil. I. Pacheco, Tania (Org). II. Leroy, Jean Pierre

(Org.). III. Título.

CDD - 22.ed. - 363.70981

2013

EDITORA FIOCRUZ

Av. Brasil, 4.036 - Térreo - sala 112 - Manguinhos

21040-361 - Rio de Janeiro, RJ

Tels.: (21) 3882-9039/3882-9041

Fax: (21) 3882-9006

editora@fiocruz.br

www.fiocruz.br/editora 


\section{Autores}

\section{Arsênio Oswaldo Sevá Filho}

Engenheiro, doutor em geografia humana e organização do espaço pela Universidade de Paris I; livre-docente do Instituto de Geociência da Universidade Estadual de Campinas (Unicamp)

\section{Bruno Milanez}

Engenheiro, doutor em política ambiental pela Lincoln University (Nova Zelândia); professor do Departamento de Engenharia de Produção e Mecânica e do Programa de Pós-Graduação em Geografia da Universidade Federal de Juiz de Fora (UFJF)

\section{Cristiane Faustino}

Assistente social; membro da Rede Brasileira de Justiça Ambiental, do Grupo de Trabalho Combate ao Racismo Ambiental, da Articulação de Mulheres Brasileira, do Fórum Cearense de Mulheres e do Instituto Negra do Ceará; relatora nacional para o Direito Humano ao Meio Ambiente - Plataforma Direitos Humanos Econômicos, Sociais, Culturais e Ambientais (Dhesca)

\section{Dário Bossi}

Missionário Comboniano, membro da Rede Justiça nos Trilhos

\section{Diogo Rocha}

Sociólogo, mestre em saúde pública pela Escola Nacional de Saúde Pública Sergio Arouca da FundaçãoOswaldoCruz(Ensp/ Fiocruz), aluno do doutorado internacional Direitos Humanos, Saúde Global e Políticas da Vida - Fiocruz/Universidade de Coimbra; pesquisador do Mapa de Conflitos Envolvendo Injustiça Ambiental e Saúde no Brasil da Fiocruz

\section{Gabriela Scotto}

Antropóloga, doutora em antropologia social; professora do Departamento de Ciências Sociais do Instituto de Ciências da Sociedade e Desenvolvimento Regional da Universidade Federal Fluminense (UFF); pesquisadora do Núcleo de Estudos Socioambientais (Nesa)/UFF

\section{Horácio Antunes de Sant'Ana Júnior}

Sociólogo, doutor em ciências humanas (sociologia) pela Universidade Federal do Rio de Janeiro (UFRJ); professor assistente do Departamento de Sociologia e Antropologia e dos Programas de PósGraduação em Ciências Sociais e Políticas Públicas da Universidade Federal do Maranhão (UFMA), coordenador do Grupo de Estudos Desenvolvimento, Modernidade e Meio Ambiente (GEDMMA)/ UFMA

\section{Jean Pierre Leroy (organizador)}

Filósofo, mestre em educação pelo Instituto de Estudos Avançados em Educação da Fundação Getulio Vargas (FGV); assessor da Federação de Órgãos para Assistência Social e Educacional (Fase) Solidariedade e Educação

\section{Jeovah Meireles}

Geólogo, doutor em geografia pela Universidade de Barcelona; professor associado do Departamento de Geografia e dos Programas de Pós-Graduação em Geografia e Desenvolvimento e Meio Ambiente da Universidade Federal do Ceará (UFC) 


\section{Julianna Malerba}

Historiadora, mestre em planejamento urbano e regional pela Universidade Federal do Rio de Janeiro (UFRJ); coordenadora do Núcleo Justiça Ambiental e Direitos da Federação de Órgãos para a Assistência Social e Educacional (Fase)

\section{Karina Kato}

Economista, doutora em ciências sociais pelo Programa de Pós-Graduação de Ciências Sociais em Desenvolvimento, Agricultura e Sociedade da Universidade Federal Rural do Rio de Janeiro (UFRRJ); pesquisadora e assessora técnica do Instituto Políticas Alternativas para o Cone Sul (Pacs)
Marcelo Firpo Porto (organizador)

Engenheiro de produção e psicólogo, doutor em engenharia de produção pela Coppe/Universidade Federal do Rio de Janeiro (UFRJ); pesquisador do Centro de Estudos da Saúde do Trabalhador e Ecologia Humana da Escola Nacional de Saúde Pública Sergio Arouca da Fundação Oswaldo Cruz (Cesteh/Ensp/Fiocruz)

\section{Tania Pacheco (organizadora)}

Jornalista, doutora em história pela UniversidadeFederal Fluminense(UFF); coordenadora executiva do Mapa de Conflitos Envolvendo Injustiça Ambiental e Saúde no Brasil da Fundação Oswaldo Cruz (Fiocruz) 


\section{Sumário}

$\begin{array}{ll}\text { Prefácio } & 9\end{array}$

Apresentação 13

1 - Metodologia e Resultados do Mapa: uma síntese dos casos de injustiça ambiental e saúde no Brasil

Tania Pacheco, Marcelo Firpo Porto e Diogo Rocha

2 - A Iniludível e Desumana Prevalência do Racismo Ambiental nos

Conflitos do Mapa

Tania Pacheco e Cristiane Faustino

3 - Povos Indígenas e Comunidades Tradicionais: os visados territórios

dos invisíveis

Jean Pierre Leroy e Jeovah Meireles

4 - Injustiça Ambiental no Campo e nas Cidades: do agronegócio

químico-dependente às zonas de sacrifício urbanas

Marcelo Firpo Porto

5 - Injustiça Ambiental, Mineração e Siderurgia

Bruno Milanez, Gabriela Scotto, Horácio Antunes de Sant'Ana Júnior,

Dário Bossi e Karina Kato

6 - Capitalismo e Energia: alguns mecanismos básicos dos conflitos e das injustiças sofridas pelo povo brasileiro

Arsênio Oswaldo Sevá Filho

7 - O Mapa como Espaço de Cidadania: reflexões e continuidades

Cristiane Faustino, Tania Pacheco, Marcelo Firpo Porto e Julianna Malerba

Jean Pierre Leroy, Tania Pacheco, Marcelo Firpo Porto e Diogo Rocha 


\section{Prefácio}

Os mapas sempre guiaram os seres humanos ao longo de sua história. No curso do desenvolvimento da humanidade, a representação gráfica de atributos biofísicos teve crescente valorização à medida que as sociedades e os Estados se estruturavam. Era preciso contar as pessoas, a produção, as riquezas... Entre os mapas mais difundidos no imaginário popular, estão certamente os 'mapas dos tesouros' que inspiraram aventureiros e escritores em todos os cantos do planeta.

Atualmente, o desenvolvimento tecnológico da informação e das comunicações possibilita cada vez mais a produção de mapas extremamente complexos e o acesso a eles: há os que são de interesses do Estado para fins de planejamento e de defesa; os voltados para interesses das grandes corporações internacionais em ampliar suas margens de lucro; aqueles vinculados ao desenvolvimento da ciência e tecnologia; e existem aqueles destinados a facilitar a mobilidade cotidiana, produzidos com equipamentos simplificados de Sistemas de Posicionamento Global (GPS), hoje amplamente disponíveis na sociedade.

No campo da sociedade civil organizada, algumas indagações se apresentam sobre os mapas. Para que servem, como devem ser construídos e quais os seus objetivos? Na perspectiva dos movimentos sociais, as pessoas e a possibilidade de seu bem viver são o elemento mais importante em qualquer mapa. Os mapas criados com base na vivência dos movimentos sociais e populares, das populações tradicionais, das comunidades impactadas pelos grandes projetos do desenvolvimento trazem em si um conhecimento emancipatório na medida em que nascem da luta pela vida e são capazes de evidenciar a diversidade dos povos do campo, das florestas, das águas e das cidades como sujeitos e atores centrais de seus territórios, integrantes das principais riquezas da nação brasileira.

O desenvolvimento de questões de saúde e ambiente no âmbito da saúde coletiva e no sistema de vigilância do Sistema Único de Saúde (SUS) tem possibilitado trazer à tona, além dos tradicionais riscos e danos à saúde, um conjunto significativo de vulnerabilidades socioambientais que estão relacionadas aos processos de produção e consumo que ocorrem nos territórios em escala global, nacional, regional e local. 
Como categoria de análise, as vulnerabilidades socioambientais apresentam à saúde coletiva um importante desafio teórico e conceitual: o de construir modelos complexos que possibilitem novas interpretações da realidade, de forma a evidenciar os cenários dos múltiplos processos socioambientais que, quando considerados na perspectiva dos marcos tradicionais de análise, não são plenamente explicitados. Ao serem integradas aos modelos de análise, tais vulnerabilidades revelam alguns elementos da complexa cadeia da determinação da saúde, especialmente entre os grupos populacionais localizados à margem ou nas bordas da inclusão cidadã.

As vulnerabilidades socioambientais representam um novo plano ou camada de informação complementar e suplementar aos indicadores de saúde já consagrados na saúde pública, os quais, de maneira geral, informam sobre padrões de mortalidade, morbidade, riscos à saúde e dados socioeconômicos reconhecidos.

As informações sobre o mapa detalhadas neste livro não constam das bases de dados do Instituto Brasileiro de Geografia e Estatística (IBGE) ou do Banco de Dados do Sistema Único de Saúde (Datasus). O material georreferenciado sobre as vulnerabilidades é construído com base nas informações existentes sobre situações de conflito vividas pelos grupos populacionais que têm sido atingidos por processos econômicos e intervenções para geração de infraestrutura e energia que, na perspectiva desses grupos, evidenciam as rupturas e impactos nos sistemas sociais, econômicos e ambientais dos territórios em que vivem.

As centenas de cenários de conflito apresentadas no mapa podem e devem ser utilizadas como elementos norteadores por todos os setores do SUS. Essas informações são úteis aos profissionais da saúde para que estes compreendam a natureza e algumas das explicações sobre as consequências da injustiça ambiental na saúde das pessoas que se encontram sob seus cuidados; aos gestores, para que sejam levadas em consideração no processo de planejamento, implantação e avaliação de suas ações; e aos agentes de controle social, para que integrem os grupos afetados às redes de organização da sociedade em defesa da saúde.

As vulnerabilidades socioambientais descortinadas pelo mapa trazem à tona complexos processos, o que possibilita compreender os cenários sanitários e planejar ações de saúde levando em consideração as percepções e os interesses desses grupos sociais profundamente vulnerabilizados. Tais percepções e interesses são um manifesto das vidas que pulsam nos territórios e dizem não a um modelo predatório de desenvolvimento. Auxiliam aqueles 
que buscam novos elementos para compreender os conflitos ambientais e sanitários e configuram, assim, uma fonte de informação de conteúdo estratégico para a busca de transformações socioambientais voltadas para a construção de outro modelo de sociedade, mais justa e ecológica.

OMapa de Conflitos Envolvendo Injustiça Ambiental e Saúde no Brasil (ou Mapa de Conflitos) deve ser entendido como ferramenta para o planejamento das ações de saúde no contexto da estruturação das regiões de saúde do SUS. Em julho de 2012, pudemos avaliar na Cúpula dos Povos, durante a Rio+20, outras experiências internacionais envolvendo mapas da mesma natureza, tanto na América do Norte como na Europa, e constatar o vanguardismo da experiência brasileira. A experiência do Mapa de Conflitos ainda não tem paralelo em outras partes do mundo, com relação à escala, objeto e método. Este trabalho expressa uma forma de operacionalização da chamada 'ecologia de saberes' - termo criado pelo professor Boaventura de Sousa Santos, da Universidade de Coimbra - mediante a qual os saberes científico e popular dialogam em igualdade de condições para construir um novo conhecimento de caráter emancipatório e transformador.

Que lutemos para vigiar e cuidar de nosso maior tesouro, o tesouro da vida! O livro apresenta mais uma ferramenta para enfrentar esse desafio desejamos-lhes uma boa luta.

Fernando Ferreira Carneiro

Doutor em epidemiologia, professor da Universidade de Brasília, chefe do Departamento de Saúde Coletiva e coordenador do Grupo de Trabalho de Saúde e Ambiente da Associação Brasileira de Saúde Coletiva (Abrasco)

Guilherme Franco Netto

Diretor do Departamento de Vigilância em Saúde Ambiental e Saúde do Trabalhador Ministério da Saúde e membro do Grupo de Trabalho Saúde e Ambiente da Associação Brasileira de Saúde Coletiva (Abrasco) 


\section{Apresentação}

\section{Introduzindo o Mapa de Conflitos}

Com o Mapa de Conflitos Envolvendo Injustiça Ambiental e Saúde no Brasil (ou Mapa de Conflitos), ${ }^{1}$ busca-se, essencialmente, identificar, sistematizar e tornar públicos os conflitos ambientais provenientes das lutas contra as injustiças e o racismo ambiental nos territórios onde foram, estão ou serão realizados diferentes projetos econômicos e políticas governamentais. Tais projetos e políticas, muitas vezes, acabam por discriminar, impactar e vulnerabilizar as populações que vivem e trabalham nesses territórios mediante a distribuição desigual dos benefícios e cargas.

Não se assumiu aqui uma visão romântica acerca dos atingidos e das injustiças ambientais. Para um caso ser pesquisado e fazer parte do mapa é necessário, antes de tudo, que ele configure um conflito claramente deflagrado. Muitas vezes não se incorporaram denúncias, mesmo cruéis, que envolvam casos de injustiça ambiental que não tenham provocado uma reação por parte da comunidade, ou ainda de organizações e movimentos sociais solidários. Nesses casos, sempre que possível, buscou-se encaminhar a denúncia a quem de direito, porém sem incluí-la no mapa. Por isso, considera-se o Mapa de Conflitos a ponta do iceberg de um número muito maior de situações de injustiça ambiental que marcam o Brasil e seu modelo de desenvolvimento.

O modelo de desenvolvimento subjacente que gera injustiças é marcado pela concentração de riquezas, por processos decisórios pouco democráticos, pela exploração insustentável dos recursos naturais e pelo desrespeito aos direitos humanos fundamentais das populações - à saúde, à moradia, ao ambiente saudável, à participação ou à preservação da cultura e da integridade comunitárias. Portanto, tornar públicos e debater os conflitos ambientais representa, mais que uma estratégia de democratização das informações, a busca por sociedades mais justas e sustentáveis num momento em que as crises socioambientais se tornam cada vez mais planetárias e emblemáticas de uma crise civilizatória mais ampla.

\footnotetext{
${ }^{1}$ Disponível em: <www.conflitoambiental.icict.fiocruz.br>.
} 
O projeto do mapa está em contínua reconstrução, aperfeiçoamento e divulgação. Começou a ser montado em 2008, sob a responsabilidade da Fundação Oswaldo Cruz (Fiocruz) e da Federação dos Órgãos para Assistência Social e Educacional (Fase) e apoio do Departamento de Vigilância em Saúde Ambiental e Saúde do Trabalhador, do Ministério da Saúde. É um dos resultados da cooperação entre a Fiocruz e a Fase iniciada em 2004 cujo objetivo principal é apoiar os movimentos em favor da justiça ambiental no país, especialmente as demandas e ações da Rede Brasileira de Justiça Ambiental (RBJA).

É fundamental entender o mapa como um processo, na medida em que foi lançado oficialmente em março de 2010, com um total de 297 conflitos, abrangendo todos os estados brasileiros, exceto o Distrito Federal e, desde então, cerca de uma centena de casos a ele foram agregados, ao mesmo tempo que muitos outros, já inclusos no mapa, tinham seus dados complementados com fatos novos. Até seu lançamento, foram 18 meses de trabalho, coletando e verificando informações, editando as fichas preenchidas pelos pesquisadores e, finalmente, disponibilizando-as na Internet. A história do mapa não se inicia, entretanto, em meados de 2008.

Portanto, aqui serão brevemente relatados o percurso histórico com as principais iniciativas que culminaram no presente mapa, que incluem a criação da RBJA, a construção do Mapa dos Conflitos Ambientais no Estado do Rio de Janeiro e a do Mapa de Conflitos Causados por Racismo Ambiental no Brasil, e o desenvolvimento do Banco Temático no âmbito da RBJA. Antes, porém, será feita uma sucinta introdução conceitual sobre o tema central do livro: os conflitos ambientais, os movimentos por justiça ambiental e sua relevância para o campo da saúde pública.

\section{Justiça Ambiental e Saúde: articulando produção de conhecimentos e ação política}

A noção de justiça ambiental, em particular sua vertente ligada à saúde pública, emerge da articulação entre áreas como o meio ambiente, a educação, os direitos humanos e a saúde pública no processo de compreensão da forma como os problemas ambientais afetam diversificadamente diferentes grupos sociais e territórios (Porto \& Pacheco, 2009).

O tema da saúde sempre esteve presente nos movimentos por justiça ambiental nos Estados Unidos desde seu início, nos anos 1980 (Wing \& Wolf, 2000). Ainda que o tema das desigualdades sociais e dos determinantes sociais da saúde seja central na história do campo da saúde coletiva e do 
movimento sanitarista brasileiro, apenas recentemente tais assuntos vêm sendo relacionados com os problemas ambientais (Freitas, 2005).

Nos Estados Unidos, o ponto inicial dos movimentos de justiça ambiental remonta à luta contra o racismo ambiental que começou no final dos anos 1970, a partir da realização de estudos que evidenciavam a presença de populações negras em regiões que seriam escolhidas para o estabelecimento de indústrias químicas altamente poluentes ou para a implantação de depósitos de rejeitos e de lixo contaminado. Mas, desde o final dos anos 1980, o movimento se ampliou e se internacionalizou, passando a abranger, além das questões ligadas aos rejeitos químicos, ações em prol de justiça ambiental que buscavam articular a questão ambiental com a defesa dos direitos humanos universais e passaram a incorporar outras formas de discriminação além da racial, como classe social, etnia e gênero (Bullard, 1990; Bullard \& Wrigty, 1993; Porto, 2007; Pacheco, 2007). Portanto, a justiça ambiental deve ser vista menos do ponto de vista da judicialização dos conflitos e relações sociais e mais do ponto de vista ético, político, da democracia e dos direitos humanos (Porto \& Pacheco, 2009).

Mais especificamente, a noção de justiça ambiental surge no cenário acadêmico brasileiro principalmente a partir dos anos 2000, inicialmente no campo da sociologia ambiental (Acselrad, 2004; Acselrad, Herculano \& Pádua, 2004) e posteriormente no campo da saúde pública (Porto, 2007; Freitas, Barcellos \& Porto, 2004). Porém, relacionados a este campo devem ser mencionados trabalhos desenvolvidos nos anos anteriores nos quais, sem se mencionar o termo 'justiça ambiental', relacionavam-se as desigualdades sociais com o tema ambiental nas áreas da saúde dos trabalhadores e da saúde ambiental por meio da discussão de questões como qualidade de vida, riscos tecnológicos, processos produtivos, vulnerabilidade social e amplificação sociopolítica dos riscos (Porto \& Freitas, 1996; Porto \& Freitas, 1997; Herculano, Porto \& Freitas, 2000; Freitas, Porto \& Machado, 2000; Tambellini \& Câmara, 2002; Rigotto, 2001; Augusto \& Freitas, 1998).

Com a noção de justiça ambiental, resgata-se e se reatualiza, em articulação com a problemática ambiental, uma longa tradição do campo das ciências sociais e da própria medicina social, por meio do desenvolvimento de trabalhos acadêmicos imbricados com demandas de movimentos sociais no enfrentamento das desigualdades sociais e na luta pela democracia. A ação engajada dos pesquisadores envolvidos com tal problemática - muitos deles ativistas oriundos de movimentos de luta por direitos humanos ou pertencentes às comunidades afetadas por problemas ambientais e práticas 
racistas - traz à tona as propostas de uma ciência ativista (Martinez-Alier et al., 2011) ou de uma ciência cidadã (Irwin, 1998).

No contexto norte-americano, têm se desenvolvido metodologias intensivas que envolvem a participação comunitária similares à da pesquisaação, tais como a pesquisa baseada na comunidade-community-based research (Israel et al., 1998) ou a ciência de rua - street science (Corburn, 2005). Nessas abordagens, consideram-se centrais na compreensão e no enfrentamento das injustiças a voz e as experiências dos sujeitos das comunidades afetadas por discriminação e conflito.

Além disso, o aumento da participação das comunidades, populações e movimentos sociais no conjunto das investigações tem outra justificativa importante, de caráter epistemológico e metodológico: contextualizar o trabalho científico, método frequentemente negado pelos adeptos da prática da 'ciência normal', ainda que se proclamem cientistas críticos ou não positivistas. Segundo Thomas Kuhn (1987), tal prática, na busca por objetividade e neutralidade, afasta a investigação científica dos valores e incertezas envolvidos, ou ainda do necessário trabalho inter/transdisciplinar. Contudo, na verdade, são justamente os conflitos, valores e incertezas que caracterizam os problemas socioambientais mais graves e urgentes da época (Funtowicz \& Ravetz, 1994).

Uma alternativa é justamente incorporar os valores em jogo e construir coletivamente estratégias de ação por meio da formação de comunidades ampliadas de debates ou de pesquisa. Para tanto, com as metodologias propostas, possibilita-se, entre outros objetivos, combinar descobertas e vivências locais com procedimentos e conceitos acadêmicos; incorporar distintas formas de conhecimentos situados e tradicionais, presentes na vivência cotidiana e nas culturas das populações; delinear situaçõesproblema que preocupam cidadãos e populações frequentemente ausentes das prioridades institucionais e grupos de pesquisa; e gerar outras formas coletivas de construção de agendas de investigação (Porto \& Milanez, 2009).

Não é suficiente, na perspectiva da justiça ambiental, apenas reconhecer as dificuldades e injustiças. É necessário transformá-las em questões concretas, motivos de ação e transformação conscientes e organizados por parte tanto das populações afetadas quanto da sociedade em geral. Portanto, é preciso disposição política para enfrentar os problemas, e isso ocorre à medida que estes são explicitados e reconhecidos como embates ou conflitos que refletem os diferentes interesses, visões de mundo e projetos de desenvolvimento em disputa. 
A emergência e intensificação dos conflitos ambientais, principalmente nas últimas décadas de globalização econômica do capitalismo, resultam de uma visão de desenvolvimento economicista, restrita e pautada por critérios produtivistas e consumistas que desrespeitam a vida humana e os ecossistemas, bem como a cultura e os valores dos povos nos territórios onde os investimentos e as cadeias produtivas se realizam (Porto \& Milanez, 2009). Os conflitos ambientais têm sido objeto de investigação de pesquisadores no campo das ciências sociais e ambientais, incluindo-se a geografia política e a ecologia política (Acselrad, 2004; Acselrad, Herculano \& Pádua, 2004; Little, 2004; Martinez-Alier, 2007; Herculano \& Pacheco, 2006; Porto, 2007).

Os conflitos ambientais decorrentes da disputa entre os diferentes modelos de desenvolvimento abarcam não apenas movimentos sociais organizados, empresas agroexportadoras e indústrias transnacionais, mas também instituições regulatórias e políticas públicas (Acserald, 2004). As situações de injustiça ambiental são compreendidas, nessa perspectiva, como consequência de disputas políticas e simbólicas envolvendo os distintos projetos e aplicações dos recursos nos territórios, assim como o uso do poder para impor esses projetos. As injustiças se transformam em conflitos à medida que resistências e mobilizações vão se instaurando, e, por isso, muitas situações de injustiças permanecem invisíveis para a sociedade diante do déficit democrático e das assimetrias de poder. Além da utilização da força direta, o poder se exerce por meios econômicos, políticos e simbólicos em diferentes instâncias. Por exemplo, nas políticas públicas, nas instituições e no acesso aos seus processos decisórios, na mídia, no campo da justiça, da academia e do desenvolvimento científico-tecnológico.

Na América Latina, as lutas por justiça ambiental se difundem principalmente a partir dos anos 2000. Nessa região, geralmente, além da elevada desigualdade social e discriminação étnica, as situações de injustiça ambiental emergem em virtude da inserção dos países latino-americanos na economia internacional por intermédio da exploração intensiva e simultânea de recursos naturais e força de trabalho, ou seja, pelo seu papel na exportação de commodities rurais e metálicas. O Brasil, apesar de seu relativo desenvolvimento econômico, industrial e institucional em comparação a outros países latino-americanos, é também marcado por forte concentração de renda e poder e, portanto, por inúmeras situações de injustiça ambiental (Porto \& Milanez, 2009).

Entender os processos de adoecimento e o próprio sentido de saúde no contexto de tais conflitos permite, em nossa concepção, compreender a 
função da saúde coletiva no campo da saúde ambiental no enfrentamento das desigualdades sociais e o papel histórico da saúde pública na construção de sociedades justas e democráticas (Porto \& Pacheco, 2009). A partir da incorporação do tema justiça ambiental na área da saúde coletiva, não apenas se repensam novas práticas de promoção, comunicação e educação em saúde próximas e articuladas aos interesses das populações mais vulnerabilizadas, como também se enfrenta o desafio de aproximar epistemologia e política na construção de uma ciência a serviço da justiça social e da sustentabilidade ambiental.

\section{A Criação da Rede Brasileira de Justiça Ambiental}

Em setembro de 2001, realizou-se na Universidade Federal Fluminense (UFF), em Niterói, o Colóquio Internacional sobre Justiça Ambiental, Trabalho e Cidadania, reunindo movimentos sociais, sindicatos, organizações não governamentais (ONGs), entidades ambientalistas, ecologistas, organizações dos movimentos negros, lideranças indígenas e representantes da academia do Brasil e do exterior. Até então, praticamente não se discutia o conceito justiça ambiental no país, e a produção acadêmica acerca do assunto estava relacionada basicamente aos movimentos de luta por direitos civis nos Estados Unidos, onde se passou a incorporar o tema racismo ambiental no final dos anos 1970 e, posteriormente, o tema justiça ambiental no final dos anos 1980 .

Um dos mais importantes resultados desse colóquio foi a criação da RBJA, lançada oficialmente no Fórum Social de Porto Alegre em 2002 com a leitura da sua Declaração de Princípios (www.justicaambiental.org. br/_justicaambiental/pagina.php?id=229). A declaração foi inicialmente assinada por 46 entidades de todo o Brasil, representando movimentos sociais, entidades ambientalistas, ONGs, associações de moradores e populações atingidas, sindicatos e centrais sindicais, pesquisadores universitários e núcleos de instituições de pesquisa/ensino. Decidiu-se que a secretaria executiva da RBJA funcionaria inicialmente na Fase/RJ, já que nesta entidade, em conjunto com outras instituições, desenvolvia-se o Projeto Brasil Sustentável e Democrático (BSD), que já existia desde janeiro de 1998 e foi estratégico para a promoção do debate sobre a temática justiça ambiental no país.

A RBJA se consolidou desde 2002 como um espaço de identificação, solidarização e fortalecimento dos princípios de justiça ambiental - marco conceitual que aproxima as lutas populares pelos direitos sociais e humanos, 
a qualidade coletiva de vida e a sustentabilidade ambiental. Constituiuse, desde então, em um fórum de discussões, denúncias, mobilizações estratégicas e articulação política que tem como objetivo formular alternativas e potencializar ações de resistência desenvolvidas por seus membros.

No portal da RBJA na Internet (www.justicaambiental.org.br), é possível encontrar maiores informações sobre sua origem, seus princípios, principais movimentos e até mesmo os documentos que circularam entre 2002 e 2009 por meio do chamado Banco Temático. Também estão lá as principais definições conceituais e os princípios que norteiam as ações de seus membros. Por exemplo, o conceito justiça ambiental se refere ao tratamento justo e ao envolvimento pleno de todos os grupos sociais, independente de sua origem ou renda, nas decisões sobre o acesso, ocupação e uso dos recursos naturais em seus territórios. Nas lutas por justiça ambiental, defendem-se:

1) os recursos ambientais como bens coletivos para o presente e para o futuro, cujos modos de apropriação e gestão devem ser objeto de debate público e de controle social;

2) os direitos das populações do campo e da cidade a uma proteção ambiental equânime como forma de combater a discriminação socioterritorial e a desigualdade ambiental;

3) os acessos à saúde coletiva por meio do uso sustentável dos recursos ambientais, de sua preservação e do combate à poluição, à degradação ambiental, à contaminação e à intoxicação química que atingem especialmente as populações que vivem e trabalham nas áreas sob influência dos empreendimentos industriais e agrícolas;

4) os direitos dos atingidos por mudanças climáticas, exigindo que as políticas de mitigação e adaptação priorizem a assistência aos grupos diretamente afetados;

5) a valorização das diferentes formas de viver e produzir nos territórios, reconhecendo a contribuição que grupos indígenas, quilombolas e outras comunidades tradicionais, agroextrativistas e agricultores familiares dão à conservação dos ecossistemas;

6) o direito a ambientes culturalmente específicos das comunidades tradicionais;

7) a alteração radical do atual padrão de produção e de consumo. 


\section{O Mapa dos Conflitos Ambientais no Estado do Rio de Janeiro}

O debate sobre problemas ambientais sob a ótica das desigualdades sociais, políticas, econômicas e culturais e, portanto, das injustiças presentes no modelo hegemônico de sociedade já era fundamental e estruturante em entidades como a Fase, mais especificamente no projeto BSD. Com a criação da rede, pode-se dizer que o projeto acumulou mais força política, aglutinando diferentes sujeitos e impondo novos desafios à sua prática. Antes da criação da RBJA, o debate sobre os conflitos ambientais no país já tinha sido realizado por iniciativas de várias entidades e grupos universitários, como o Instituto Brasileiro de Análises Sociais e Econômicas (Ibase), a Central Única dos Trabalhadores do Rio de Janeiro (CUT-RJ), pesquisadores do Instituto de Pesquisa e Planejamento Urbano e Regional (Ippur) e do Museu Nacional da Universidade Federal do Rio de Janeiro (UFRJ), da UFF, além de outros grupos acadêmicos ligados às ciências sociais e à saúde coletiva, como a Fiocruz (Herculano, Porto \& Freitas, 2000; Ibase/CUT-RJ/Ippur/UFRJ, 2000). Os problemas ambientais já eram tema obrigatório das discussões inseridas no projeto BDS/Fase, e, com a criação da rede, novos parceiros fomentaram a ideia de se construir um Mapa de Conflitos Ambientais do Rio de Janeiro (Acselrad, Herculano \& Pádua, 2004).

Com o vigor da recém-criada RBJA, em novembro de 2002 o BSD/Fase promoveu uma oficina para se pensar numa forma de viabilizar essa estratégia de luta em torno dos conflitos e movimentos por justiça ambiental, partindo do levantamento do "perfil do conhecimento disponível, das pesquisas em andamento e dos esforços dos pesquisadores" que se dedicavam, "no âmbito das mais diversas instituições universitárias e de pesquisa, ao estudo de conflitos ambientais no Estado do Rio de Janeiro", conforme consta da apresentação do CD-ROM "Mapa dos Conflitos Ambientais no Estado do Rio de Janeiro 2002-2005". Como consequência da oficina, em janeiro de 2004 o projeto BSD/Fase e o laboratório Estado, Trabalho, Território e Natureza (Ettern/Ippur/UFJR) lançavam o Mapa dos Conflitos Ambientais do Estado do Rio de Janeiro 1992-2002.

Com o apoio da Secretaria de Estado de Meio Ambientee Desenvolvimento Urbano do Rio de Janeiro e com recursos provenientes de um Termo de Ajuste de Conduta da Petrobras, após o desastre ambiental ocorrido na baía de Guanabara em 2000, o mapa foi produzido em CD-ROM no qual se compilaram 251 casos cujos registros foram colhidos de documentos da Fundação Estadual de Engenharia do Meio Ambiente (Feema) e dos ministérios públicos estadual e federal. Deles, 183 diziam respeito a atividades 
industriais; 48, à ausência de saneamento; dez conjugavam essas duas questões; e outros dez envolviam temas diversos.

Dois anos mais tarde, em 2006, os mesmos parceiros lançaram um novo Mapa dos Conflitos Ambientais no Estado do Rio de Janeiro, também em CD-ROM, totalizando, assim, 480 conflitos ocorridos entre 2002 e 2005, aos quais foram ainda acrescentados estudos analíticos dos casos. Às fontes iniciais - Feema e os ministérios públicos estadual e federal - se somariam também casos registrados pelo Departamento de Recursos Minerais do Estado do Rio de Janeiro, pela Secretaria Municipal de Meio Ambiente do Rio de Janeiro e pela Secretaria de Urbanismo e Meio Ambiente de Mesquita. ${ }^{2}$

Os conflitos, selecionados ao longo de trinta meses, relativos ao período de 2002 a 2005, foram georreferenciados em 68 municípios e sistematizados em 18 classificações específicas: mineração; disposição não licenciada de resíduos industriais; depósito licenciado de resíduos industriais; armazenamento temporário de resíduos industriais; poluição atmosférica; poluição de corpo hídrico; poluição do solo; poluição sonora; gasodutos, oleodutos, estações rádio-base e linhas de transmissão; vazadouros de lixo; lançamento de esgoto em corpo hídrico; acesso à água potável; apropriação de corpo hídrico; deslocamento compulsório de assentamento humano; ocupações irregulares; moradia de risco; comprometimento da pesca; e futuros empreendimentos (Acselrad, 2004).

Ainda de acordo com as informações apresentadas no CD-ROM,

Os casos foram organizados por município de ocorrência do evento denunciado e classificados em grandes categorias, segundo o tipo de problema ambiental a que estiveram associados, a saber: conflitos associados a atividades industriais - poluição industrial da água, do ar e do solo, mineração irregular e disposição irregular de resíduos industriais; conflitos associados à falta de saneamento, localização e operação de lixões e aterros sanitários; conflitos associados simultaneamente a atividades industriais e à falta de saneamento; e outros.

\section{O Mapa de Conflitos Causados por Racismo Ambiental no Brasil}

Enquanto se produzia o segundo CD-ROM sobre os conflitos do estado do Rio de Janeiro, o debate acerca da necessidade de criação de instrumentos de registros e publicização dos casos de injustiça ambiental no país começaram a se intensificar dentro da própria RBJA, presente nas discussões coletivas nos

\footnotetext{
${ }^{2}$ O Mapa dos Conflitos Ambientais no Estado do Rio de Janeiro 2002-2005 continua disponível na
} sede da Fase - Rua das Palmeiras, 90, Rio de Janeiro. 
encontros nacionais e oficinas que reuniam membros da rede. Paralelamente, em um dos seus grupos de trabalho - o GT Combate ao Racismo Ambiental, instituído em 2005 -, buscavam-se recursos para outro mapa, que teria como foco a identificação, em todo o país, dos conflitos ambientais que tinham como um de seus principais determinantes o racismo. Essa proposta, que constituía um forte desafio à ação do GT, foi aprovada pela plenária de encerramento do I Seminário Brasileiro contra o Racismo Ambiental, em novembro de 2005, por ele organizado. Trabalhando com base em sua lista eletrônica de contatos e nos depoimentos colhidos durante o seminário (Herculano \& Pacheco, 2006) ${ }^{3}$ e contando com o auxílio de uma pesquisadora em tempo parcial nos quatro meses finais, a então coordenadora do GT Combate ao Racismo Ambiental, Tania Pacheco, conseguiu fazer um levantamento inicial do que foi chamado de Mapa de Conflitos Causados por Racismo Ambiental no Brasil. ${ }^{4}$

Lançado em poucas cópias xerocadas durante o II Encontro da RBJA, em 2007, e reunindo 120 casos, distribuídos por todos os estados exceto o Distrito Federal, o piloto do que deveria ser o Mapa do Racismo Ambiental trazia duas inovações. A primeira era que os dados tinham por base as denúncias das populações atingidas e de seus parceiros. A segunda estava no fato de que em raríssimos casos os conflitos eram informados por algum tipo de fonte institucional; quando isso acontecia, novamente era por intermédio das comunidades, de seus parceiros ou com base em notícias veiculadas na Internet que informações como a ação do Ministério Público, da Defensoria Pública ou de algum órgão estatal eram coletadas. Em muitos casos, essa ação era criticada, e os órgãos públicos eram acusados de corresponsáveis, por omissão ou conivência, quando não eram denunciados como os próprios causadores do conflito.

A produção de conhecimento compartilhada e o protagonismo das populações atingidas são elementos marcantes nos movimentos por justiça ambiental e influenciaram tanto o Mapa do Racismo quanto, posteriormente, o da Injustiça Ambiental. Isso não se reduz apenas à opção política e metodológica de se valerem das vozes e das denúncias dos povos e comunidades. Está presente também no trabalho de busca de possibilidades de solidariedade e de alianças entre os diferentes sujeitos envolvidos. Além disso, o Mapa

\footnotetext{
${ }^{3}$ Os depoimentos estão também disponíveis em vídeo no endereço eletrônico: <www.racismoambiental.net.br/i-seminario $>$.

${ }^{4}$ Disponível em: <www.fase.org.br/projetos/clientes/noar/noar/UserFiles/17/File/Microsoft\%20 Word\%20-\%20MAPA_DO_RACISMO_AMBIENTAL_NO_BRASIL.pdf>.
} 
de Conflitos Envolvendo Injustiça Ambiental e Saúde no Brasil desvela uma realidade que se configura como um importante instrumento de identificação e debate sobre o racismo presente nas injustiças ambientais (Pacheco, 2008).

Embora abandonado já em 2007, o Mapa de Conflitos Causados por Racismo Ambiental no Brasil serviu de referência na estruturação do Mapa de Conflitos Envolvendo Injustiça Ambiental e Saúde no Brasil de várias formas. Por exemplo, a ficha inicial, o formato e as informações básicas daquele foram incorporados a este. No primeiro mapa, apresentaram-se os conflitos em um quadro no qual figuravam os seguintes dados: localização; tipo de conflito; grupo atingido; agressores (responsáveis pelo conflito); apoios, articulações e parcerias. Além disso, havia um título, seguido de uma síntese e de um histórico mais elaborado, o qual se encerrava com a explicitação das fontes utilizadas e de outras que eram sugeridas para aprofundamento. Podemos, pois, dizer que nesse primeiro mapa já estavam presentes as diretrizes e a estrutura básicas do mapa atual. ${ }^{5}$

Essa convergência não acontece por acaso. Embora influenciado diretamente pelos três mapas mencionados - Mapa de Conflitos Causados por Racismo Ambiental no Brasil, Mapa dos Conflitos Ambientais no Estado do Rio de Janeiro 1992-2002 e Mapa dos Conflitos Ambientais no Estado do Rio de Janeiro 2002-2005-, é inegável que foi a concepção política e metodológica do primeiro que influenciou a construção do Mapa de Conflitos Envolvendo Injustiça Ambiental e Saúde no Brasil, aqui apresentado. Mesmo considerando os limites e as dificuldades que são partes desse tipo de processo, pelo viés da democratização da informação e do conhecimento, e das estratégias coletivas de enfrentamento aos conflitos ambientais, as duas propostas apresentam importantes alternativas de inclusão das populações atingidas.

A falta de recursos fez com que o Mapa de Conflitos Causados por Racismo Ambiental no Brasil ficasse restrito aos 120 conflitos iniciais, registrados de forma precária, mas, até 2010, disponíveis no portal da RBJA. ${ }^{6}$ As informações do mapa foram retiradas do portal da rede por três motivos: os dados nele contidos estavam desatualizados, não correspondiam mais à realidade; apesar disso, ele continuava a ser consultado e citado por pessoas que ainda o pensavam válido; e os mesmos casos se tornaram disponíveis,

\footnotetext{
${ }^{5}$ Seguindo essa mesma lógica, o formulário construído no FormSUS e utilizado para a coleta dos dados registrados no Mapa de Conflitos consta do Anexo deste livro.

${ }^{6}$ Atualmente, ele ainda pode ainda ser acessado no endereço já mencionado, juntamente com muitos outros documentos produzidos pelo projeto Brasil Sustentável e Democrático e ao longo dos anos iniciais da RBJA, como parte de sua memória.
} 
muito mais detalhadamente pesquisados e atualizados, no Mapa de Conflitos Envolvendo Injustiça Ambiental e Saúde no Brasil. Na verdade, não só por já estarem registrados como, acima de tudo, por sua importância e contundência, esses 120 conflitos foram os primeiros a ter seus dados integrados ao novo mapa.

\section{O Banco Temático da RBJA}

Em 2004, como já se mencionou, foi assinado um convênio de cooperação técnico-científico entre a Fiocruz e a Fase, que sediava a secretaria executiva da RBJA, visando a incentivar estudos, assessorias e ações voltados para a promoção da saúde e da justiça ambiental. No âmbito da Fiocruz, o grupo de pesquisa intitulado "Eco-Social: abordagens integradas para a promoção da saúde e justiça ambiental envolvendo populações vulneráveis" assumiu a coordenação do convênio.

Uma de suas primeiras iniciativas, em resposta à demanda colocada no I Encontro da RBJA, realizado no Rio de Janeiro em outubro de 2004, foi o desenvolvimento de um projeto de pesquisa para a criação de um banco temático, com o apoio do Conselho Nacional de Desenvolvimento Científico e Tecnológico (CNPq), da própria Fiocruz e do Mount Sinai Hospital de Nova York. Dentre os objetivos centrais da proposta, destacavam-se: dar visibilidade aos conflitos ambientais, aos riscos e problemas de saúde das populações envolvidas em situações de injustiça ambiental; potencializar os processos políticos de resistência às situações de injustiça ambiental em curso na sociedade por meio do intercâmbio de informações e experiências; disponibilizar textos relacionados com a temática da justiça ambiental, assim como propiciar estudos sobre a atuação da RBJA e de movimentos por justiça ambiental no país.

O Banco Temático consiste em um conjunto de aproximadamente 3.500 documentos postos em circulação entre 2002 e 2009 pelos membros da RBJA, e se encontra disponível para consulta pública na página da RBJA (www. justicaambiental.org.br). Na lista de tais documentos se incluem notícias, campanhas, relatórios, denúncias, artigos, documentos jurídicos e laudos técnicos que circularam na rede, indexados por pesquisadores do projeto e bolsistas do Programa de Iniciação Científica (Pibic/Fiocruz) formados nesse período (Porto \& Pacheco, 2009).

Além de ferramenta para o intercâmbio de experiências e realização de pesquisas sobre justiça ambiental, o Banco Temático serviu de base para a produção de relatórios apresentados nos encontros presenciais 
da rede, os quais analisam a evolução da própria RBJA por meio dos documentos que nela circularam. Produziram-se relatórios para os anos 20022006 e outro para 2007-2008. Em termos de contribuições específicas para o Mapa de Conflitos Envolvendo Injustiça Ambiental e Saúde, o Banco Temático se destaca de três formas: como fonte de informação para o levantamento de casos; como base para a definição de duas categorias ('atividades geradoras de injustiça ambiental' e 'população'); como elemento de apoio na formação de quadros de pesquisadores no campo das ciências sociais engajados nos movimentos por justiça ambiental, pois três ex-bolsistas do Banco Temático acabaram se inserindo como pesquisadores no projeto do Mapa de Conflitos. Em 2010, o projeto deixou de indexar novos documentos, após fechar o ano 2009, e sua continuidade está atualmente associada a uma proposta de resgate da história das lutas e discussões temáticas no âmbito da RBJA, por intermédio dos boletins que serão produzidos.

\section{O Mapa de Conflitos e sua Importância para a Luta pela Justiça Ambiental}

Identificar, sistematizar e publicizar os conflitos ambientais por meio das lutas contra as injustiças e o racismo ambiental representam, sobretudo, uma estratégia de democratização das informações, explicitando não só impactos sociais e ambientais como outras faces perversas do modelo de desenvolvimento econômico, político e cultural dominante no Brasil e no mundo. Combater o ocultamento de tais conflitos é, portanto, estratégico para reduzir os processos de vulnerabilização das populações atingidas, promovendo simultaneamente a cidadania, a justiça ambiental e a saúde numa perspectiva mais ampla (Acselrad, Herculano \& Pádua, 2004; Porto, 2007; Porto \& Pacheco, 2009).

Não por acaso, pode-se ler ainda na página inicial do portal:

Seu objetivo [do mapa] maior é, a partir de um mapeamento inicial, apoiar a luta de inúmeras populações e grupos atingidos/as em seus territórios por projetos e políticas baseadas numa visão de desenvolvimento considerada insustentável e prejudicial à saúde por tais populações, bem como movimentos sociais e ambientalistas parceiros.

Já nesse trecho se percebe o principal elemento que torna o mapa um importante instrumento na luta contra a injustiça e o racismo ambientais: ao registrar os conflitos nos quais povos e comunidades estão envolvidos, principalmente os da zona rural, das florestas e de parte da zona costeira, ele tira da invisibilidade grupos que têm suas vidas ameaçadas nos territórios 
em que vivem e trabalham, que lutam pelo direito de neles permanecerem e para terem acesso justo aos recursos deles provenientes. Nesse sentido, funciona como uma espécie de tribuna, de escudo para povos indígenas, quilombolas, camponeses sem-terra, ribeirinhos, pescadores artesanais e tantas outras comunidades tradicionais, que dificilmente encontram espaço nos meios de comunicação. Num contexto em que os conflitos ambientais são marcados por ameaças e violências contra os povos e comunidades, a visibilidade é também um importante instrumento de proteção - pelo menos até onde isso é possível, considerando a impunidade que envolve jagunços, pistoleiros e mandantes de assassinatos no Brasil.

Além disso, o mapa é também um instrumento importante de democratização das políticas e das instituições, não só por contribuir para denunciar e tornar públicos os responsáveis pelos conflitos como também por permitir a cobrança e o monitoramento da ação dos governos e da Justiça incluindo-se os ministérios e as defensorias públicas, federais e estaduais. O mapa foi pensado também como um instrumento a ser usado pelo Ministério da Saúde na detecção de lugares onde sua atuação é urgente e necessária e de locais onde sua cobertura já aconteça, mas precisa ser melhorada ou corrigida, incluindo-se a implementação e aprimoramento de políticas de saúde específicas, como as de saúde ambiental, da população negra e da população indígena.

O uso potencial do mapa para o setor saúde tornou-se ainda mais relevante após a realização da I Conferência Nacional de Saúde Ambiental, realizada entre 9 e 12 de dezembro de 2009 em Brasília. A diretriz mais votada ao final da conferência se refere à

mudança no modelo de desenvolvimento econômico de modo a promover a qualidade de vida e a preservação do ambiente, e a saúde desta e das futuras gerações com a proteção da agrobiodiversidade e da biodiversidade urbana e rural, visando à sustentabilidade socioambiental responsável. (Brasil, 2010)

Outra diretriz refere-se a

implantação, fortalecimento e implementação da sustentabilidade socioambiental nas políticas públicas considerando os espaços urbano e rural, bem como a vulnerabilidade ambiental para a definição dos Programas de Territórios de Cidadania considerando as necessidades sociais das populações da cidade, do campo, da floresta e do litoral, promovendo justiça ambiental e inclusão social, com primazia da participação popular. (Brasil, 2010)

Portanto, para a efetivação de um SUS democrático que esteja voltado para a vigilância e promoção da saúde, cuja base seja territorial e que incorpore 
efetivamente os determinantes socioambientais, é preciso também incluir o tema justiça ambiental e seus movimentos nas intervenções em casos concretos de populações atingidas.

A esse respeito, não é desimportante o fato de o Mapa de Conflitos ter o apoio de um ministério do governo federal. Ao abrigá-lo, este cumpre uma das missões de qualquer governo democrático: reforçar o Estado republicano, permitindo que setores sociais marginalizados e ignorados tenham voz pública.

Com um projeto como o do mapa, o Estado - no caso, por meio do Ministério da Saúde e da Fiocruz - cumpre seu papel de fiador e mantenedor da democracia ao garantir o direito da população a explicitar suas demandas e é também fiel da balança democrática, contrapeso que permite a expressão dos injustiçados e vítimas do desenvolvimento. Isso é particularmente importante num momento em que, com um determinado ideário do desenvolvimento, busca-se subordinar Estado e governos à "política do crescimento a qualquer custo", que confunde progresso com crescimento econômico e desigual, fomentando a injustiça e o racismo ambientais, silenciando e tornando invisíveis importantes setores da sociedade.

Pode-se falar o mesmo do papel a ser desempenhado pela academia e da importância de sua presença neste projeto. Para que os movimentos por justiça ambiental tenham chance de serem ouvidos e respeitados, é fundamental dar densidade e consistência às denúncias e ações. Nestes tempos em que a ciência, não poucas vezes, subordina-se ao mercado e se restringe a uma visão especializada, fragmentada e tecnicista de produção de conhecimento, não é indiferente ter, nas estratégias de luta que com o mapa se propiciam, a parceria de intelectuais engajados, de acadêmicos que, sem abrir mão do rigor científico, colocam-se do lado das vítimas do desenvolvimento e do poder econômico dominante, na defesa dos seus direitos e da justiça social e ambiental.

Paralelamente, com o mapa se revela a presença de um leque variado de outras entidades da sociedade civil que apoiam os grupos sociais atingidos. E, embora se entenda que sua ação não pode nem deve substituir o poder público ou os sujeitos sociais dos conflitos, sua importância mediadora é inegável.

Outro ponto importante a ser realçado é sua interatividade. O mapa na versão digital possibilita que mesmo pessoas com pouca intimidade com a Internet tenham facilidade em consultá-lo e, se for o caso, em se comuni- 
car por meio desta ferramenta, fazendo novas denúncias, corrigindo ou complementando dados. E isso vem ocorrendo de fato desde que ele foi lançado. Entidades, organizações, lideranças representativas de grupos e comunidades, assim como pessoas físicas com evidente dificuldade de se manifestar por escrito, utilizam o Fale Conosco como importante espaço de exercício da cidadania. Todas as mensagens são lidas, avaliadas e, quando necessário, trabalhadas pela equipe.

É fundamental, entretanto, que cada vez mais o mapa seja apropriado por todos os sujeitos e entidades envolvidos nas lutas sociais e ambientais, fazendo dele um instrumento para o aprimoramento da democracia e para a garantia dos direitos humanos e da cidadania plena. Nesse sentido, desde o final de 2010 se está trabalhando na construção de núcleos estaduais ou regionais, vinculados à RBJA, que possam acompanhar de perto os conflitos registrados no mapa, envolvendo como parceiras entidades que assumam o compromisso de indicar novos casos a serem acrescentados e monitorar o andamento daqueles já existentes, complementando dados à medida que o conflito apresentar novos desdobramentos. Essa é também uma estraté gia para articular e reunir, em torno de uma ação coletiva, diversos sujeitos que atuam contra as injustiças ambientais em todo o Brasil.

Como já mencionado na apresentação do Mapa de Conflitos Envolvendo Injustiça Ambiental e Saúde no Brasil,

O foco do mapeamento (...) é a visão das populações atingidas, suas demandas, estratégias de resistência e propostas de encaminhamento. As fontes de informação privilegiadas e sistematizadas nos casos apresentados seguiram essa orientação. (...) Os casos selecionados não esgotam as inúmeras situações existentes no país, mas refletem uma parcela importante nos quais populações atingidas, movimentos sociais e entidades ambientalistas vêm se posicionando. (grifo nosso)

Tanto não se esgotam tais situações que quase cem casos já foram agregados aos 297 iniciais desde o segundo semestre de 2010, e muitos outros estão sendo trabalhados para no mapa serem inseridos. Esse desdobramento revela que o mapa está cumprindo um dos seus objetivos centrais como instrumento de democratização da sociedade brasileira.

\section{A Estrutura do Livro}

Como este livro tem como tema o Mapa de Conflitos, mas não trata apenas dele, houve uma preocupação inicial em se explicar a forma como se chegou ao mapa. Essa explicação está no capítulo 1, em que se apresenta a metodologia utilizada e se resumem os casos presentes no mapa. Já a 
partir do capítulo seguinte, o livro toma outro caminho: os resultados e as conclusões que podemos colher do mapa passam a ser objeto de diferentes análises específicas, servindo de base para questionamentos, observações críticas e sugestões sobre alternativas de enfrentamento das causas geradoras dos conflitos em pauta. Em última instância, o que se encontra em jogo é a crítica do modelo hegemônico de desenvolvimento que impõe interesses de curto prazo dos grupos mais poderosos às populações atingidas.

No capítulo 2, adentra-se num um terreno pouco discutido nos meios acadêmicos, mas que o Mapa de Conflitos nos desafia a encarar, dado o caráter de insofismável prevalência que assume no conjunto da pesquisa: o racismo ambiental. Nele se analisa a forma como o capital utiliza o racismo e o preconceito para expulsar povos indígenas, quilombolas e comunidade tradicionais de seus espaços originários, de suas culturas e tradições, no campo, ao passo que, nas cidades, pobreza e negritude predominam nos embates com a especulação imobiliária e as indústrias poluentes.

Grande parte dessas personagens é retomada no capítulo 3, em que os conflitos são objeto de análise sob um enfoque complementar especializado: o da territorialidade. Trabalhadores rurais também são mencionados, mas o protagonismo do estudo recai novamente sobre os povos originários e as comunidades tradicionais, com seus embates pelo direito a um território que, para eles, tem um significado que até mesmo os operadores do sistema de Justiça enfrentam dificuldade de compreender.

No capítulo 4, discutem-se as injustiças ambientais nos espaços das cidades, campos e florestas. Trata-se de uma questão de grande complexidade, já que tais espaços são influenciados por inúmeras dinâmicas que tanto os diferenciam como os interconectam. Por exemplo, no campo destacamos a expansão do agronegócio, dos monocultivos e o uso intensivo dos agrotóxicos, mas isso também influencia a migração campo-cidade e o conjunto da população que consome alimentos contaminados. Nas cidades, a perversa combinação das desigualdades socioespaciais com empreendimentos, como complexos portuários e indústrias perigosas, intensifica a formação das zonas de sacrifício. Porém, tais empreendimentos também avançam sobre os espaços onde vivem populações indígenas, quilombolas e camponesas.

Abordam-se, nos capítulos 5 e 6, duas forças motrizes de grande relevância para a geração de conflitos ambientais no contexto brasileiro: a primeira trata da mineração e da siderurgia, e a segunda da produção de energia. A mineração é uma atividade intensiva em recursos naturais, especialmente o solo e a água. Isso coloca em risco os ecossistemas e a existência de outras 
formas de produção que dependem diretamente do meio ambiente, como a agricultura, a pesca e o turismo, além de envolver também questões culturais e simbólicas. A importância do minério de ferro no Brasil, o poder das grandes corporações e a transferência da fase quente da siderurgia - mais perigosa, poluente e eletrointensiva - por parte dos países centrais para outros da Ásia e América Latina justificam uma análise integrada desses setores.

No capítulo 6, discutem-se os riscos e consequências socioambientais das principais atividades de produção e uso de combustíveis e de eletricidade, em especial os combustíveis fósseis (carvão, petróleo e gás) e as usinas termelétricas e hidrelétricas. O ponto de partida é uma discussão conceitual sobre o sistema capitalista e energia que fundamenta a compreensão sobre as lutas políticas em torno dos conflitos, tornando evidente por que alternativas energéticas ditas 'verdes' ou 'sustentáveis' podem se tornar o oposto quando o combustível mais relevante é a acumulação do capital.

Finalmente, os dois últimos capítulos trazem reflexões sobre as potencialidades e desafios do Mapa de Conflitos como espaço de cidadania, além de seus possíveis desdobramentos e alternativas no futuro. No capítulo 7 , apresenta-se a iniciativa do mapa como produção e democratização de conhecimentos estratégicos no enfrentamento das injustiças ambientais por meio de sua articulação com a mobilização social e as políticas públicas. Obviamente, trata-se de uma iniciativa que se soma a muitas outras, levadas a cabo por cidadãos organizados que buscam recolocar na cena pública problemas comuns e diferentes formas de abordá-los.

No capítulo 8, discutem-se os desafios de mudança em um cenário mais amplo do capitalismo globalizado, com as ameaças do crescimento a qualquer custo e uma conjuntura política que reforça os interesses econômicos dos mais poderosos sobre a ação pública usando sua influência nas esferas do Executivo, do Judiciário e do Legislativo. As contradições atuais da economia capitalista refletem um dilema ético-filosófico sobre o próprio Estado de Direito: de um lado, busca-se assegurar que os interesses diferentes e até contraditórios das classes e dos grupos e setores sociais possam coexistir; de outro, que a cidadania dos setores marginalizados e fragilizados seja garantida.

Mas de que forma garantir essa cidadania, e qual espaço de questionamento sobra à sociedade? De que sociedade se está falando, e que futuro está sendo construído neste momento? Outro futuro não será por uma sociedade de consumidores egocêntricos que viram as costas para a política. As transformações virão por movimentos populares solidários, respaldados por políticas públicas e mecanismos de produção compartilhada de 
conhecimentos que respondam aos clamores éticos e políticos por novas práticas científicas e institucionais.

Construir esse mosaico de discussões e reflexões não foi uma tarefa simples. Por isso, gostaríamos de agradecer aos demais autores que aceitaram o desafio de escrever conosco este livro. Fernando Carneiro e Guilherme Franco Neto, que acreditaram no nosso sonho, nos apoiaram em diferentes e decisivos momentos, e assinam o Prefácio, merecem um obrigado especial. Finalmente, não seria sequer justo deixarmos de mencionar a participação de Diogo Rocha, que, em paralelo à elaboração do mapa e deste livro, soube construir seu caminho e, além de ser hoje o principal pesquisador da equipe e um dos autores aqui presentes, participou ativamente da própria organização desta coletânea.

Nesse espírito de construção de solidariedades políticas, o Mapa de Conflitos Envolvendo Injustiça Ambiental e Saúde no Brasil não pertence à Fiocruz, à Fase, à Rede Brasileira de Justiça Ambiental ou ao Ministério da Saúde, que o apoiou financeiramente até o momento. Ele pertence a cada brasileiro, aos povos indígenas, aos quilombolas, às comunidades tradicionais, aos trabalhadores urbanos, a todas as entidades e organismos comprometidos com a luta por um Brasil mais justo. Ele é de cada um de nós, e cabe a nós seguir construindo-o e utilizando-o, da melhor forma possível.

Os organizadores 


\section{Referências}

ACSELRAD, H. (Org.). Conflito Social e Meio Ambiente no Estado do Rio de Janeiro. Rio de Janeiro: Relume Dumará, 2004.

ACSELRAD, H.; HERCULANO, S. \& PÁDUA, J. A. Justiça Ambiental e Cidadania. Rio de Janeiro: Relume Dumará, 2004.

AUGUSTO, L. \& FREITAS, C. M. O princípio da precaução no uso de indicadores de riscos químicos ambientais em saúde do trabalhador. Ciência \& Saúde Coletiva, 3(2): 85-95, 1998.

BRASIL. Ministério da Saúde. Relatório final da 1ํㅡㄹ Conferência Nacional de Saúde Ambiental (CNSA). Brasília, 2010. Disponível em: <www.conselho.saude.gov.br/biblioteca/Relatorios/ CNSA_Relatorio_Final.pdf $>$. Acesso em: 23 maio 2011.

BULLARD, R. Dumping in Dixie: race, class, and environmental quality. Oxford: Westview Press, 1990.

BULLARD, R. D. \& WRIGTHY, B. H. Environmental justice for all: community perspectives on health and research needs. Toxicology and Industrial Health, 9(5): 821-841, 1993.

CORBURN, J. Street Science: community knowledge and environmental health justice. Cambridge: The MIT Press, 2005.

FREITAS, C. M. A produção científica sobre o tema ambiente na saúde coletiva. Cadernos de Saúde Pública, 21(3): 679-701, 2005.

FREITAS, C. M.; BARCELLOS, C. \& PORTO, M. F. S. Justiça ambiental e saúde coletiva. In: ACSELRAD, H. (Org.). Conflitos Ambientais no Brasil. Rio de Janeiro: Relume Dumará, 2004.

FREITAS, C. M.; PORTO, M. F. S. \& MACHADO, J. M. H. Acidentes Industriais Ampliados: desafios e perspectivas para a prevenção e o controle. Rio de Janeiro: Editora Fiocruz, 2000.

FUNTOWICZ, S. \& RAVETZ, J. Emerging complex systems. Futures, 26(6): 568-582, 1994.

HERCULANO, S. \& PACHECO, T. (Orgs.). Racismo ambiental. In: SEMINÁRIO BRASILEIRO CONTRA O RACISMO AMBIENTAL, I, Rio de Janeiro. Anais... Rio de Janeiro: Fase, 2006.

HERCULANO, S.; PORTO, M. F. S. \& FREITAS, C. M. (Orgs.). Qualidade de Vida \& Riscos Ambientais. Niterói: EdUFF, 2000.

IBASE; CUT-RJ \& IPPUR/UFRJ. Sindicalismo e Justiça Ambiental. Rio de Janeiro: Ibase, $2000.3 \mathrm{v}$.

IRWIN, A. Ciência Cidadã: um estudo das pessoas, especialização e desenvolvimento sustentável. Lisboa: Instituto Piaget, 1998.

ISRAEL, B. A. et al. Review of community-based research: assessing partnership approaches to improve public health. Annual Review of Public Health, 19: 173-202, 1998.

KUHN, T. A Estrutura das Revoluções Científicas. São Paulo: Perspectiva, 1987.

LITTLE, P. E. A Etnografia dos Conflitos Socioambientais: bases metodológicas e empíricas. In: II ENCONTRO DA ANPPAS, Indaiatuba. Anais... Indaiatuba, 2004.

MARTINEZ-ALIER, J. O Ecologismo dos Pobres: conflitos ambientais e linguagens de valoração. São Paulo: Contexto, 2007

MARTINEZ-ALIER, J. et al. Between science and activism: learning and teaching ecological economics with environmental justice organisations. Local Environment, 16(1): 17-36, 2011.

PACHECO, T. Desigualdade, injustiça ambiental e racismo: uma luta que transcende a cor, 2007. Disponível em: <www.racismoambiental.net.br/textos-e-artigos/tania-pacheco/desigualdadeinjustica-ambiental-racismo>. Acesso em: 15 jul. 2012. 
PACHECO, T. Racismo ambiental: expropriação do território e negação da cidadania. In: SUPERINTENDÊNCIA DE RECURSOS HÍDRICOS - SRH - (Org.). Justiça pelas Águas: enfrentamento ao racismo ambiental. Salvador: Superintendência de Recursos Hídricos, 2008.

PORTO, M. F. Uma Ecologia Política dos Riscos. Rio de Janeiro: Editora Fiocruz, 2007.

PORTO, M. F. S. \& FREITAS, C. M. Major chemical accidents in industrializing countries: the socio-political amplification of risk. Risk Analysis, 16: 19-29, 1996.

PORTO, M. F. S. \& FREITAS, C. M. Análise de riscos tecnológicos ambientais: perspectivas para o campo da saúde do trabalhador. Cadernos de Saúde Pública, 13(1): 59-72, 1997.

PORTO, M. F. S. \& MILANEZ, B. Eixos de desenvolvimento econômico e geração de conflitos socioambientais no Brasil: desafios para a sustentabilidade e a justiça ambiental. Ciência \& Saúde Coletiva, 14: 1.983-1.994, 2009.

PORTO, M. F. S. \& PACHECO, T. Conflitos e injustiça ambiental em saúde no Brasil. Tempus Actas em Saúde Coletiva, 4(4): 26-37, 2009.

RIGOTTO, R. M. (Org.). As Tramas da (In)Sustentabilidade: trabalho, meio ambiente e saúde no Ceará. Fortaleza: Inesp, 2001.

TAMBELLINI, A. \& CÂMARA, V. Vigilância ambiental em saúde: conceitos, caminhos e interfaces com outros tipos de vigilância. Cadernos de Saúde Coletiva, X(1): 77-93, 2002.

WING, S. \& WOLF, S. Intensive livestock operations, health, and quality of life among eastern North Carolina residents. Environ Health Perspect, 108(3): 233-238, 2000. 


\section{1}

\section{Metodologia e Resultados do Mapa: uma síntese dos casos de injustiça ambiental e saúde no Brasil}

Tania Pacheco

Marcelo Firpo Porto

Diogo Rocha

Considerações Metodológicas: ciência engajada e saúde como expressão de direitos e conflitos nos territórios

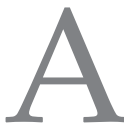

ntes de apresentarmos os resultados do Mapa de Conflitos Envolvendo Injustiça Ambiental e Saúde no Brasil (ou Mapa de Conflitos), ${ }^{1}$ é importante identificar os principais elementos da metodologia que orientaram sua construção. Um primeiro aspecto, de natureza conceitual e política, diz respeito à sua finalidade principal: o objetivo não se reduz a listar territórios onde riscos e impactos ambientais afetam diferentes populações, mas sim reconhecer tais populações como portadoras de direitos, tornando públicas vozes, frequentemente discriminadas e invisibilizadas pelas instituições e pela mídia, que clamam por justiça. A prática de uma ciência engajada ou cidadã (Irwin, 1995; Martinez-Alier, 2009) adotada neste projeto demanda uma posição ética solidária com essas populações.

Tal postura não é contrária às visões científicas da realidade, pois o posicionamento solidário deve se apoiar em argumentações legítimas acerca dos impactos, riscos e efeitos presentes nos territórios. Reconhecemos que os conflitos apresentados são complexos, envolvem múltiplos problemas e valores e exigem soluções de curto, médio e longo prazo, que incluam mudanças estruturais nos sistemas de produção e consumo das sociedades

\footnotetext{
${ }^{1}$ Disponível em: <www.conflitoambiental.icict.fiocruz.br>.
} 
capitalistas modernas, bem como nas políticas públicas e nas práticas das instituições. Porém, o reconhecimento da complexidade, das incertezas e da falta de conhecimento mais consistente acerca da dinâmica dos impactos socioambientais levantados não deveria gerar imobilismos, ou ainda considerar como ilegítimas as preocupações, denúncias e demandas das populações atingidas nos territórios. E, muitas vezes, é justamente isto que se dá em certa prática da 'ciência normal', no sentido atribuído por Thomas Kuhn (1987): quando se analisam problemas socioambientais complexos de forma especializada, desconsideram-se, em nome da neutralidade e pretensa objetividade (Funtowicz \& Ravetz, 1994), os valores e posições das populações mais vulneráveis e discriminadas nos conflitos.

Quando se adota uma visão engajada no âmbito de uma ciência voltada para a justiça ambiental, busca-se a primazia da ética na defesa das populações discriminadas e vulneráveis frente aos problemas ambientais nos territórios, reconhecendo-se a importância das evidências científicas (Wing, 2005). Mas, além disso, é importante adotar uma visão epistemológica crítica e precaucional diante de certos problemas ambientais causados por determinados empreendimentos, pois, em alguns casos, deveria ser central e emergencial, na defesa da vida das comunidades afetadas, a atenção à simples possibilidade de impactos atuais ou futuros à saúde e ao meio ambiente estarem associados aos danos, principalmente quando há denúncias das populações afetadas (Porto, 2007). Ou seja, é necessária uma crítica epistemológica e política que possibilite enfrentar posições imobilistas ou desqualificadoras das denúncias quando inexistem provas científicas irrefutáveis dos efeitos e danos, e as incertezas são utilizadas ou manipuladas com a intenção de impedir a responsabilização dos geradores dos riscos ou mesmo ações preventivas ou remediadoras (Michaels, 2006; Freundenberg, Gramling \& Davidson, 2008). E isso é mais relevante numa época em que a defesa do crescimento econômico e dos negócios, até mesmo de tecnologias e produtos perigosos, torna-se crescentemente influente no conjunto da sociedade, dos governos e das instituições.

O conceito de promoção da saúde que assumimos implica incorporar a defesa dos direitos humanos fundamentais, a redução das desigualdades e o fortalecimento da democracia na defesa da vida e da saúde. Isso engloba, igualmente, o direito à terra, aos alimentos saudáveis, à democracia, à cultura e às tradições, em especial das populações atingidas e frequentemente vulnerabilizadas e discriminadas. Ou seja, nossa concepção de saúde e ambiente vai além das variáveis do saneamento básico, da contaminação ambiental por poluentes e das doenças e mortes decorrentes desses fatores 
(Porto, 2007; Porto \& Pacheco, 2009) e está intimamente associada à noção de justiça ambiental.

Portanto, defender e promover a saúde significa não somente a construção de ambientes mais saudáveis, mas de uma sociedade mais fraterna, mais igualitária, em que a dignidade humana esteja no centro das prioridades. Tais objetivos são abalados quando investimentos econômicos, políticas e decisões governamentais acabam por ferir os direitos fundamentais tanto de povos indígenas, quilombolas, agricultores familiares, pescadores artesanais e comunidades tradicionais diversas como de trabalhadores e moradores das cidades que vivem nas chamadas 'zonas de sacrifício'.

\section{Os Casos Selecionados, Fontes de Informação e Conteúdos}

Os casos selecionados para o Mapa de Conflitos revelam situações emblemáticas de transformações nos territórios brasileiros decorrentes de um modelo de desenvolvimento cujos empreendimentos desprezam a vida de inúmeras populações que habitam, trabalham e com frequência têm suas vidas imbricadas com os recursos e paisagens em disputa nos seus territórios. Tais empreendimentos podem ser os mais variados, tais como indústrias petroquímicas, hidrelétricas, hidro e agronegócios para exportação, hotéis 'ecológicos' de luxo ou, ainda, aterros sanitários ou de rejeitos tóxicos.

O número de casos inicialmente levantado (quase trezentos) ilustra apenas uma parcela dos inúmeros conflitos ambientais em curso no país. Dada a escala nacional do Mapa de Conflitos, os casos selecionados representam conflitos emblemáticos que têm sido discutidos por redes e movimentos sociais engajados em lutas por justiça ambiental no Brasil. Além disso, diversos casos representam, na realidade, inúmeros subcasos de conflitos em seu interior, na medida em que o tema que recorta a área de influência do conflito pode ser um investimento, obra ou mesmo acidente ambiental cujos impactos se dão em muitos municípios e até mesmo em mais de um estado, como nos casos de minerodutos, construção de rodovias, transposição do rio São Francisco, construção de grandes hidrelétricas ou acidentes em rios que cruzam várias cidades ampliando as fronteiras da contaminação.

Como o mapeamento dos conflitos ambientais tem por objetivo tornar visíveis as populações atingidas, suas demandas, estratégias de resistência e propostas de encaminhamento, seu escopo não incluiu o desenvolvimento de trabalhos e avaliações de campo que aprofundassem, em termos técnicocientíficos, os detalhes dos impactos sobre o meio ambiente e a saúde. 
As informações destacadas sobre os casos revelam os posicionamentos das populações atingidas, manifestados diretamente por meio do relato de suas experiências e sua divulgação em encontros e documentos da Rede Brasileira de Justiça Ambiental (RBJA) e de outras redes ou movimentos sociais e indiretamente por meio de relatórios e artigos produzidos por entidades, organizações não governamentais (ONGs) e instituições parceiras, inclusive grupos acadêmicos, instituições governamentais, ministérios públicos ou órgãos do Judiciário.

As fontes de informação privilegiadas e sistematizadas nos casos apresentados seguiram essa orientação e provêm, em grande parte, do acúmulo da RBJA, incluindo-se a experiência de suas entidades, suas discussões e seus Grupos de Trabalho (GTs). Dentre eles, destacaram-se o GT Químicos e o GT Combate ao Racismo Ambiental, sendo que com informações circuladas nesse último foi feito o levantamento inicial para um Mapa de Conflitos causados pelo Racismo Ambiental no Brasil (Pacheco, 2007), que serviu de base para o mapa atual. Parte dos documentos que circulam na RBJA e em seus GTs se encontra disponibilizada no Banco Temático, ferramenta construída pela Fundação Oswaldo Cruz (Fiocruz) e pela Federação de Órgãos para Assistência Social e Educacional (Fase), acessível na Internet, que permite a consulta a documentos.

Além disso, no tratamento das informações que caracterizam os casos, incorporou-se a experiência de vários parceiros, como grupos acadêmicos e entidades que atuam nos movimentos por justiça ambiental no Brasil. Como exemplos, destacamos o Mapa dos Conflitos Socioambientais da Amazônia Legal, organizado pela Fase Belém; os dados constantes da Nova Cartografia Social, organizada pelo pesquisador Alfredo Wagner; trabalhos realizados por universidades e centros de pesquisa como o Grupo de Estudos em Temáticas Ambientais da Universidade Federal de Minas Gerais (Gesta/UFMG), o Núcleo de Investigações em Justiça Ambiental do Departamento de Ciências Sociais da Universidade Federal de São João del-Rei (Ninja/UFSJR), o núcleo de Trabalho, Meio Ambiente e Saúde para sustentabilidade da Universidade Federal do Ceará (Tramas/UFC), a Universidade Federal da Bahia (UFBA), a Universidade Federal do Mato Grosso (UFMT) e a Universidade Federal do Mato Grosso do Sul (UFMS), entre outros; os relatórios da Plataforma Brasileira de Direitos Humanos Econômicos, Sociais, Culturais e Ambientais (Descha Brasil), em especial a Relatoria do Direito Humano ao Meio Ambiente; e outras contribuições de ONGs e fóruns atuantes na Justiça Ambiental e na própria RBJA. Os dados obtidos em tais fontes foram complementados com informações da mídia ou 
de instituições, inclusive ministérios públicos e a Justiça, quando envolviam ações ou processos em andamento.

$\mathrm{O}$ fato de as posições e informações veiculadas pelas fontes utilizadas na construção dos casos muitas vezes contradizerem as versões de outras instituições ou empresas envolvidas expressa, além do grau de incertezas e falta de informações existentes, o nível de conflito e de dificuldades no encaminhamento de soluções que atendam aos interesses legítimos das populações atingidas. Privilegiando-se a visão das referidas populações e organizações parceiras, evitam-se reducionismos ou denúncias inconsequentes. A avaliação da consistência e qualidade das informações usadas na construção dos casos selecionados foi realizada mediante a leitura conjunta por parte do grupo interdisciplinar que compôs a equipe de pesquisa do mapa e a coordenação conjunta Fiocruz-Fase; o mesmo se deu na revisão dos casos, realizada por avaliadores regionais por estado, como será explicado mais adiante.

A proposta inicial foi levantar os principais conflitos em todos os estados brasileiros, com uma média de 15 por estado, o que resultou em números que vão desde cinco até trinta casos, dependendo da intensidade dos conflitos e das mobilizações. Por exemplo, estados como Roraima e Sergipe apresentam um número de casos bem menor que os levantados em Minas Gerais, Bahia, Rio de Janeiro e São Paulo. Em contrapartida, atingem áreas bem maiores, envolvendo por vezes diversos municípios num único conflito, ao passo que os do Sudeste tendem a ser mais restritamente localizados.

O levantamento teve como recorte denúncias existentes desde janeiro de 2006, mesmo que suas origens fossem anteriores a essa data. Para o fichamento dos casos, foram considerados, entre outros, os seguintes itens:

1) o tipo de população atingida e o local do conflito, como: povos indígenas, operários, quilombolas, agricultores familiares, moradores em encostas, ribeirinhos, pescadores e outros tantos, urbanos ou rurais;

2) o tipo de dano à saúde (contaminação por chumbo, desnutrição, violência física, entre outros) e de agravo ambiental (desmatamento, queimada, contaminação do solo e das águas por agrotóxicos, por exemplo);

3) a síntese do conflito e o contexto ampliado, apresentando os principais responsáveis pelo conflito, as entidades e populações envolvidas na luta por justiça ambiental, os apoios recebidos ou não (como participação de órgãos governamentais, do Ministério 
Público e de parceiros da sociedade civil), as soluções buscadas e/ou encontradas;

4) os principais documentos e fontes usadas na pesquisa sobre o caso.

As informações a serem sistematizadas na construção dos conflitos foram apresentadas e discutidas em oficina com a participação de alguns pesquisadores e militantes de ONGs que atuavam na RBJA pertencentes a campos distintos de conhecimentos e práticas, como a saúde coletiva/saúde ambiental, as ciências sociais e ambientais e o ambientalismo. Os resultados dessas discussões constituíram o principal instrumento de sistematização de informações trabalhadas para a construção de cada conflito. Tais informações foram inseridas pelos pesquisadores em um banco de dados criado com um programa do departamento de informática do Sistema Único de Saúde (Datasus), o FormSUS (ver Anexo - Instrumento FormSUS). Esse instrumento sistematiza informações em cinco grupos principais, totalizando trinta itens. São eles:

1) Localização - esse grupo informa dados como os municípios atingidos, latitude e longitude para o georrefereciamento, área rural ou urbana, entre outros. É importante destacar que o mapa, na atual versão, apresenta apenas um ponto principal como o centro do conflito, mas, em diversos casos, conforme é possível ver no próprio mapa, inúmeros municípios podem fazer parte do mesmo conflito, muitas vezes atingindo áreas rural e urbana.

2) População atingida - três variáveis caracterizam as populações atingidas: a identidade cultural, territorial e/ou social (agricultores familiares, caiçaras, marisqueiras, moradores de aterros e/ou terrenos contaminados, moradores de bairros atingidos por acidentes ambientais, moradores do entorno de lixões, moradores em encostas e favelas, operários, pescadores artesanais, povos indígenas, quebradeiras de coco, quilombolas, ribeirinhos, seringueiros e outros); a cor de pele; a estimativa do número de pessoas atingidas pelo conflito.

3) Tipologia do conflito - neste grupo são sistematizados os vários tipos de impactos ambientais, os problemas ou riscos e/ou danos à saúde, os processos produtivos e os principais responsáveis pelo conflito, e é construída uma tipologia para cada uma dessas variáveis. No caso específico da saúde, no item riscos e/ou danos à saúde, riscos se referem às suspeitas ou possibilidades de problemas de saúde relacionadas ao conflito, ao passo que danos 
dizem respeito aos problemas de saúde já existentes e, segundo populações atingidas e organizações parceiras, têm relação clara com o conflito, não se restringindo apenas a enfermidades, mas também a aspectos mais amplos e/ou subjetivos, como qualidade de vida, insegurança alimentar e desnutrição, ou ainda falta de atendimento médico. Optamos por construir uma tipologia simplificada (como doenças crônicas e doenças infecciosas), com espaço para identificar alguma patologia específica relacionada ao conflito em questão, como problemas respiratórios ou câncer. Essa opção foi definida na oficina para facilitar a compreensão inicial do conflito, mas também para destacar um conceito ampliado de saúde, no qual questões centrais, em diversas situações de injustiça ambiental, pudessem ser destacadas como problemas de saúde. Além disso, na tipologia, incluem-se os principais parceiros das populações ou comunidades atingidas, além dos responsáveis pelo conflito sob a ótica dessas populações.

4) Descrição do conflito - parte central na metodologia do mapa, contém uma síntese do conjunto de informações levantadas numa narrativa para que, com base em uma visão histórica das dimensões territoriais, políticas, econômicas e socioambientais, sejam expostos os principais valores em disputa, característicos do caso em questão e sob a lógica das populações atingidas. São quatro os itens dessa fase: a síntese do conflito, um sumário executivo com um título autoexplicativo e um breve texto introdutório; o contexto ampliado, em que se contextualiza o conflito de forma mais detalhada com base na sua história e nas disputas presentes; uma cronologia com a linha do tempo dos fatos mais relevantes que marcam o conflito; e as fontes de informação usadas.

5) Responsável pela informação - marcador interno que, junto com a data de finalização, permite identificar o pesquisador da equipe responsável pelo fichamento do caso.

À medida que as informações de cada unidade da federação eram consideradas suficientemente sistematizadas, o material era enviado para validação de um pesquisador do mesmo estado - da academia ou de movimentos sociais e ONGs - com histórico de prática engajada nos conflitos ambientais de sua região, incumbido de criticar a pesquisa realizada, complementando-a ou corrigindo dados, se necessário. Ao término dessa etapa, as fichas aprovadas eram encaminhadas para editoração e padronização e, em seguida, submetidas a uma crítica final por parte da coordenação do 
mapa, para, então, serem inseridas no banco de dados que o alimenta em sua disposição final na Internet. Essa ferramenta foi criada por uma equipe técnica do Instituto de Comunicação e Informação Científica da Fiocruz (Icict/ Fiocruz), especializada no georreferenciamento de informações sobre saúde, que utilizou Google Earth como plataforma auxiliar de localização espacial dos territórios onde os casos estavam inseridos.

Figura 1 - A página do mapa na Internet

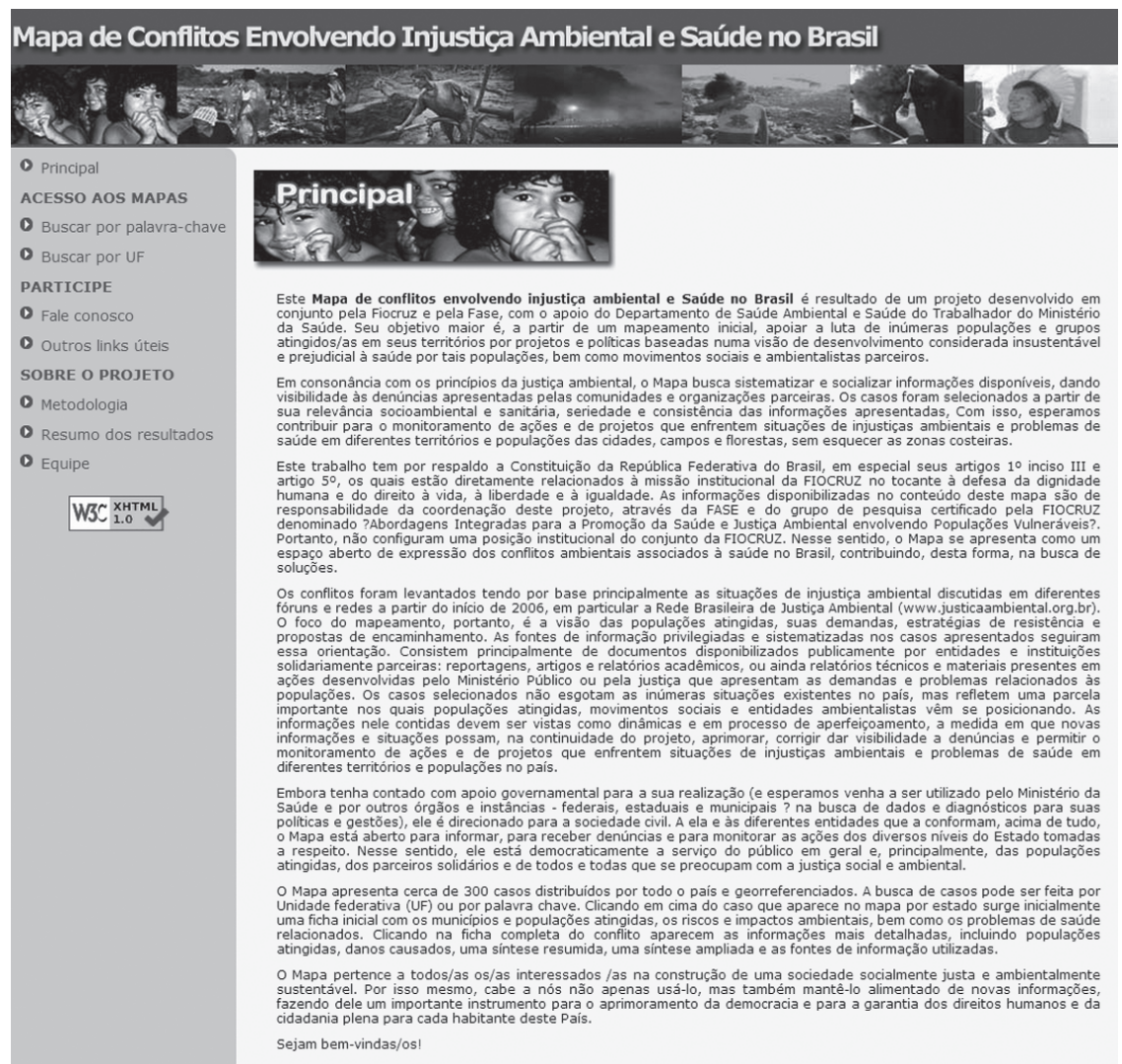

Todos os direitos reservados ao LIS/Icict/Fiocruz

Fonte: Mapa de Conflitos Envolvendo Injustiça Ambiental e Saúde no Brasil.

O resultado final encontra-se disponível na Internet desde março de 2010, quando houve um lançamento oficial com grande repercussão na mídia nacional e regional em várias partes do país. No projeto de página web desenvolvido, buscou-se o máximo de simplicidade, navegabilidade 
e atrativo visual, facilitando os instrumentos de busca a cidadãos, mesmo aqueles com pouca experiência no uso de computadores e Internet. A página inicial do mapa é mostrada na Figura 1, na qual é possível encontrar na lateral esquerda as três principais entradas do site: o Acesso ao Mapa, que contém o sistema de busca dos casos por estado ou palavra-chave; o Participe, por onde é possível se comunicar com a equipe do mapa através do envio de mensagem ou encontrar links úteis aos interessados; e o Sobre o Projeto, que dá acesso a informações gerais sobre a metodologia do mapa, um resumo dos principais resultados à época do lançamento e a equipe do projeto.

Os quase trezentos casos inicialmente disponibilizados na Internet, assim como os quase quatrocentos incluídos no mapa até 2012, não abrangem a totalidade dos inúmeros conflitos existentes no país, mas refletem uma parcela importante desses casos, sobre os quais populações atingidas, movimentos sociais e entidades ambientalistas vêm se posicionando. As informações contidas devem ser vistas como dinâmicas e em processo de aperfeiçoamento, na medida em que novos desdobramentos e situações podem, na continuidade do projeto, aprimorar, corrigir e complementar o presente resultado. Portanto, é importante ressaltar que não consideramos o mapa concluído. Pelo contrário, ele é o momento inicial de um novo espaço para denúncias, para o monitoramento de políticas públicas e, ainda, de desafio para que o Estado, em seus diversos níveis, responda às necessidades da cidadania, respeitando e implementando a Constituição Federal. É, pois, fundamental que se entenda que ele pertence a todos.

\section{Os Resultados do Mapa}

Trabalhamos não com os dados atuais do mapa, mas com os 297 conflitos iniciais disponibilizados quando de seu lançamento, em março de 2010. $\mathrm{Na}$ ocasião, tais casos consistiam nos maiores agravos às diferentes populações, diagnóstico confirmado por pesquisadores dos 26 estados. Desde então, cerca de cem novos conflitos foram agregados, dos quais uma pequena parte não existia no momento do início da pesquisa. A maioria dos casos inseridos posteriormente apresenta problemas de impacto menor do que $\mathrm{o}$ dos conflitos da primeira seleção. A gravidade dos casos da versão inicial do mapa justifica, pois, o fato de termos optado por utilizá-los como referencial para as análises empreendidas neste volume.

Nesta síntese, nosso objetivo é compartilhar uma visão de conjunto que está presente potencialmente no mapa, mas que só se torna efetivamente clara por meio de um diálogo com diversos campos, relacionados aos 
principais temas passíveis de análise. Para isso, utilizaremos alguns gráficos, comentando os principais problemas que eles revelam e que constituem uma amostra contundente do cenário que uma noção equivocada de desenvolvimento e progresso tem ajudado a construir em nosso país.

Utilizamos os dados consolidados do Mapa de Conflitos, incluindo todas as comunidades afetadas, todos os danos à saúde e assim sucessivamente, e não apenas os que constam dos formulários como os principais atingidos, responsáveis etc. Isso quer dizer que algumas informações aparecerão aqui diferentes das contidas em textos e artigos anteriores. Ao considerarmos a totalidade das comunidades, dos agravos e dos seus responsáveis, buscamos ampliar ainda mais a visibilidade dos conflitos e aprofundar a possibilidade de análise.

Apesar disso, os resultados mantiveram as mesmas conclusões principais anteriores. Considerando, por exemplo, as populações, veremos que, agora como antes, os povos indígenas continuam a ser os mais atingidos nos conflitos, seguidos de agricultores familiares e quilombolas. Há uma variação em relação aos moradores de aterros e/ou terrenos contaminados, que suplantam por pouco os ribeirinhos. Explica-se provavelmente essa diferença pelo fato de as variações que se referem aos moradores de terrenos urbanos contaminados, inóspitos, de entornos de usinas de incineração ou de lixões poderem ser, geralmente, classificadas em mais de uma categoria; com isso, tende-se a se somar um número maior de atingidos, ao passo que a comunidade dos ribeirinhos representa um grupo mais específico, e, nesse sentido, mais limitado.

Esperamos, ao socializar esses resultados, não só contribuir para revelar as principais injustiças ambientais registradas no mapa e seus impactos sobre as comunidades, sua saúde e território, como também estimular os leitores a continuarem com novas análises e colaborações.

\section{Distribuição dos Conflitos por Estado e Região: uma equação enganosa}

Analisando-se a Tabela 1, percebe-se que São Paulo, Minas Gerais, Rio de Janeiro e Bahia são os recordistas em conflitos ambientais do mapa, cada um com respectivamente $9,9 \%, 7,9 \%, 6,1 \%$ e 5,9\% do total de casos. A soma dos conflitos nos três primeiros estados acrescida daqueles ocorridos no Espírito Santo, com 3,8\%, coloca o Sudeste primeiro lugar absoluto, se considerarmos a relação entre os $27,7 \%$ dos casos que a Região totaliza e o reduzido número de estados que a constituem. Porém, devemos levar em consideração aspectos não somente quantitativos, mas também qualitativos. 
Tabela 1 - Distribuição dos conflitos por estado

\begin{tabular}{|c|c|c|c|c|c|c|}
\hline Região & Estado & $\begin{array}{l}\text { Conflitos } \\
\text { principais }\end{array}$ & $\begin{array}{l}\text { Conflitos } \\
\text { relacionados* }\end{array}$ & Total & $\begin{array}{l}\% \\
\text { por } \\
\text { estado }\end{array}$ & $\begin{array}{l}\% \\
\text { por } \\
\text { região }\end{array}$ \\
\hline \multirow{3}{*}{ Centro-Oeste } & Goiás & 8 & 1 & 9 & 2,62 & \multirow{3}{*}{9,62} \\
\hline & Mato Grosso & 13 & 3 & 16 & 4,66 & \\
\hline & Mato Grosso Sul & 6 & 2 & 8 & 2,33 & \\
\hline \multirow{9}{*}{ Nordeste } & Alagoas & 9 & 0 & 9 & 2,62 & \multirow{9}{*}{29,45} \\
\hline & Bahia & 16 & 4 & 20 & 5,9 & \\
\hline & Ceará & 9 & 3 & 12 & 3,50 & \\
\hline & Maranhão & 8 & 3 & 11 & 3,21 & \\
\hline & Paraíba & 6 & 4 & 10 & 2,92 & \\
\hline & Pernambuco & 13 & 3 & 16 & 4,66 & \\
\hline & Piauí & 4 & 1 & 5 & 1,46 & \\
\hline & $\begin{array}{l}\text { Rio Grande } \\
\text { do Norte }\end{array}$ & 9 & 0 & 9 & 2,62 & \\
\hline & Sergipe & 8 & 1 & 9 & 2,62 & \\
\hline \multirow{7}{*}{ Norte } & Acre & 8 & 0 & 8 & 2,33 & \multirow{7}{*}{21,28} \\
\hline & Amapá & 8 & 0 & 8 & 2,33 & \\
\hline & Amazonas & 15 & 2 & 17 & 4,96 & \\
\hline & Pará & 10 & 3 & 13 & 3,79 & \\
\hline & Rondônia & 9 & 0 & 9 & 2,62 & \\
\hline & Roraima & 8 & 0 & 8 & 2,33 & \\
\hline & Tocantins & 9 & 1 & 10 & 2,92 & \\
\hline \multirow{4}{*}{ Sudeste } & Espírito Santo & 13 & 0 & 13 & 3,79 & \multirow{4}{*}{27,70} \\
\hline & Minas Gerais & 23 & 4 & 27 & 7,9 & \\
\hline & Rio de Janeiro & 20 & 1 & 21 & 6,1 & \\
\hline & São Paulo & 30 & 4 & 34 & 9,9 & \\
\hline \multirow{4}{*}{ Sul } & Paraná & 15 & 2 & 17 & 4,96 & \multirow{3}{*}{11,95} \\
\hline & $\begin{array}{l}\text { Rio Grande } \\
\text { do Sul }\end{array}$ & 10 & 3 & 13 & 3,79 & \\
\hline & Santa Catarina & 10 & 1 & 11 & 3,21 & \\
\hline & Total & 297 & 46 & 343 & & \\
\hline
\end{tabular}

* Conflitos que envolvem mais de um estado. No formulário FormSUS (Anexo), há um campo chamado "O conflito abrange outros estados? Qual/is?".

Fonte: Elaborado pelos autores com base nos dados do Mapa de Conflitos Envolvendo Injustiça Ambiental e Saúde no Brasil.

O elevado número de conflitos nos estados do Sudeste está relacionado ao histórico de intensa ocupação territorial e de industrialização, com inúmeros passivos e impactos socioambientais decorrentes. Além disso, as comunidades neles envolvidas, suas ações de resistência e, ainda, movimentos sociais organizados e entidades parceiras na Região tendem a ser mais visíveis. Oestado de São Paulo, por exemplo, o que maior número de conflitos registra 
no mapa, apresenta certas peculiaridades que merecem ser mencionadas e, igualmente, transformadas em tema para algumas reflexões.

Por exemplo, tomando-se o estado do Amapá como base de comparação, verificam-se apenas oito conflitos registrados, contra os trinta de São Paulo. No entanto, esses oito conflitos do Norte atingem 100\% dos 16 municípios do estado, ao passo que os trinta casos de São Paulo afetam apenas 38 municípios, correspondendo a 5,9\% do total de 645 existentes.

Isso não acontece por acaso. Enquanto os conflitos paulistas são, na maioria, urbanos e localizados, geralmente envolvendo alguns milhares de metros quadrados, os do Amapá são contados em milhares de hectares de território, muitas vezes se estendendo de um município para outros, vizinhos. A causa é a luta pela terra, pela água e pelo lucro, tanto no Sudeste quanto no Norte. Mas, neste, os conflitos acontecem de forma mais extensa, brutal e agressiva tanto no que se refere à intensidade dos desrespeitos aos direitos fundamentais quanto no que diz respeito à atividade das instituições incumbidas de fiscalizar e proteger as populações e o meio ambiente. Isso não significa, em absoluto, que estejamos minimizando a importância e a violência dos conflitos urbanos, mas é fundamental não esquecermos que grande parte das injustiças ambientais que acontecem nas cidades tem sua origem bem longe delas, pois o metabolismo social das cidades depende, em boa parte, de recursos naturais extraídos de forma a gerar os conflitos de que nos ocupamos (Martinez-Alier, 2009; Pacheco, 2009, 2010).

A especificidade do cenário de São Paulo e sua inegável importância na realidade brasileira fazem com que seus conflitos mereçam uma rápida análise. A Figura 2 apresenta a forma como tais conflitos se distribuem no estado.

Dos trinta casos, sete dizem respeito à área rural e poderiam estar situados em diversos outros estados brasileiros, revelando que mesmo o estado mais industrializado e populoso do país também apresenta algumas características que o aproximam de outros menos industrializados. ${ }^{2}$ Dois casos envolvem povos indígenas, comunidades tradicionais e pequenos agricultores: o das usinas hidrelétricas projetadas para o Vale do Ribeira e o megaprojeto da empresa LLX, o Complexo Industrial e Portuário de Peruíbe. Outros dois afetam populações quilombolas: o Quilombo de Caçandoca, em Ubatuba, e

\footnotetext{
${ }^{2}$ Os dados referentes a São Paulo foram levantados e analisados para o texto "O mapa da injustiça ambiental e saúde e o direito à cidade, ao campo, à vida", apresentado por Tania Pacheco na mesa "Direitos Humanos: pobreza e ambiente", em 1/7/2010, no quarto simpósio"O Rio e a cidade - cidade sustentável: um direito", realizado pela Prefeitura de Mauá, São Paulo.
} 
Figura 2 - Conflitos do mapa no estado de São Paulo

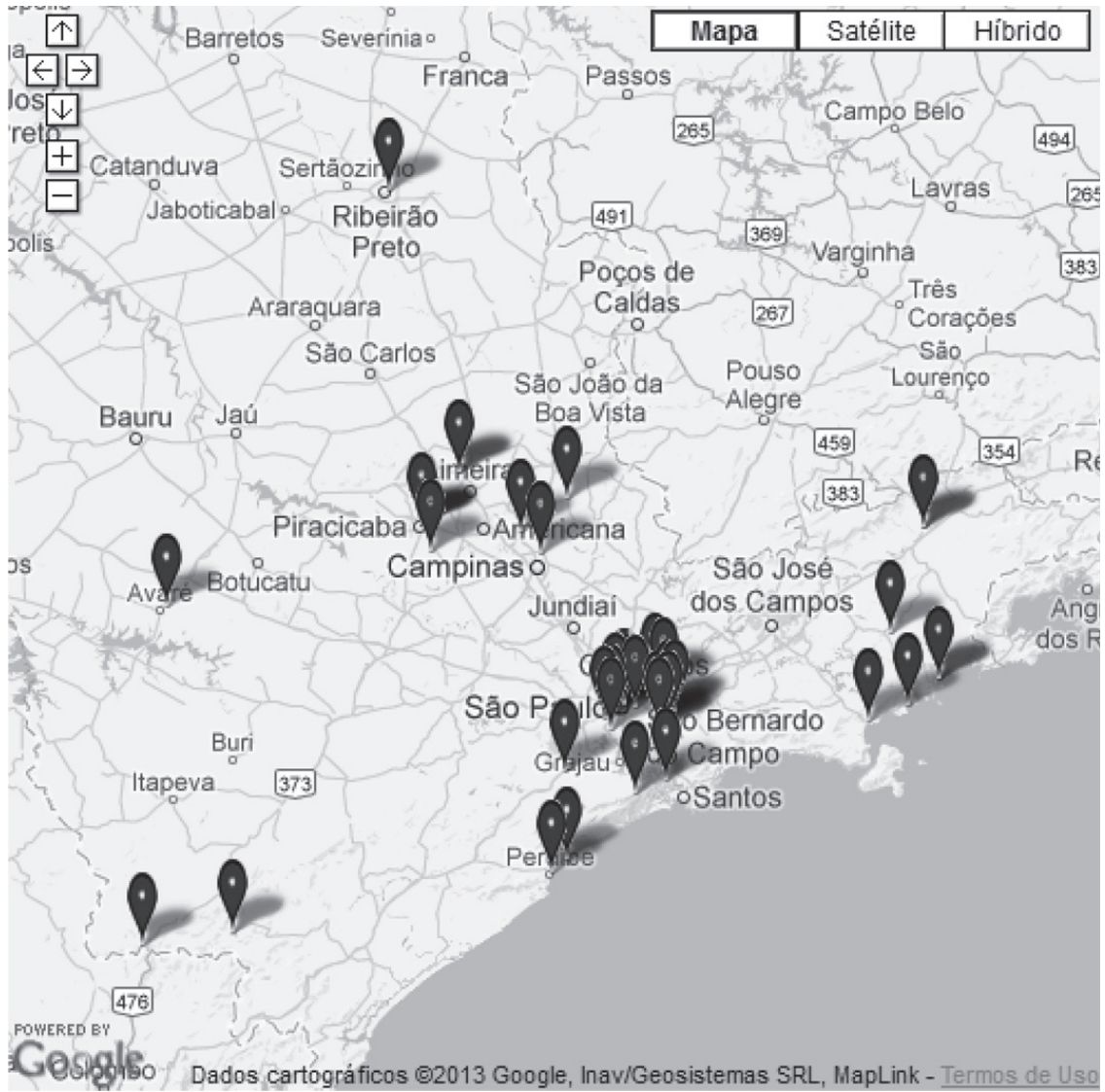

Fonte: Mapa de Conflitos Envolvendo Injustiça Ambiental e Saúde no Brasil.

o de Porto Velho, em Iporanga, também no Vale do Ribeira. Nos dois casos, há expropriação das terras e ameaças de fazendeiros. Num quinto conflito, também em Peruíbe, trezentas famílias caiçaras lutam contra a situação de ilegalidade em que foram colocadas depois da criação da Estação Ecológica Jureia-Itatins: por ser uma unidade de conservação (UC), nela não pode haver moradores, devendo o Estado proceder à expulsão das comunidades incluídas nos seus limites.

No sexto caso, verificamos o trabalho escravo na produção de cana-deaçúcar e na citricultura em Rio das Pedras, Ribeirão Preto, Mogi-Guaçu e Paranapanema. Um sétimo conflito rural foi registrado no Vale do Paraíba, onde a monocultura do eucalipto está causando o êxodo dos pequenos 
agricultores, graves danos ao meio ambiente e à saúde das pessoas em virtude da contaminação por agrotóxicos. Destaca-se esse caso dos demais porque ele abre um novo tópico: dos trinta conflitos de São Paulo, ele é o primeiro de uma lista de 23 que envolvem, de uma forma ou de outra, a contaminação química.

Vale ressaltar, antes de nos determos nesse caso de contaminação química, um oitavo conflito que é o primeiro relacionado à realidade urbana propriamente dita, na medida em que nele se registra a expulsão da população das favelas da periferia da Grande São Paulo para abrir caminho para a especulação imobiliária.

Sem esquecermos os tristemente famosos casos de Cubatão e Paulínia, onde as graves consequências das ações das empresas Rhodia e Shell não foram ainda sanadas, pois continuam sendo alvo de disputas judiciais, destacamos os registros de novas ameaças, como a instalação da Unidade de Processamento de Gás que a Petrobras está construindo em Caraguatatuba. E os casos se sucedem: Jurubatuba, considerada a área com o maior passivo ambiental da cidade de São Paulo; Favela Paraguai, onde uma comunidade de 1.700 pessoas está exposta a substâncias tóxicas carcinogênicas, contaminantes orgânicos e metais pesados; Cidade Tiradentes, cujos problemas são ainda agravados por um depósito de desmonte de carros que deixa resíduos tóxicos no terreno irregularmente ocupado; Santo Antônio de Posse, onde o aterro Mantovani recebeu 320 mil toneladas de resíduos industriais entre 1974 e 1987.

Em Campinas, no bairro Mansões de Santo Antônio, a recuperação de solventes contamina a população com poluentes nocivos à saúde. No perímetro urbano de Avaré, lixo tóxico com amianto e fenol está depositado irregularmente. Em São Mateus, o aterro São João mantém 122 toneladas de solo contaminado por hexaclorociclohexano $(\mathrm{HCH})$. Adrianópolis, Ribeira e São Lourenço da Serra sofrem ainda de alguma forma os efeitos da contaminação pelos rejeitos de uma indústria de mineração de chumbo, fechada em 1993. Em São Miguel Paulista, a Companhia Nitro Química Brasileira provoca acidentes do trabalho e ambientais desde 1935. E o chamado Polo Cerâmico do Estado, que integra Cordeirópolis, Santa Gertrudes e Rio Claro, é associado à contaminação ambiental por fluoreto gasoso e metais pesados.

Na cidade de São Paulo, a empresa Shell é apontada como responsável pela contaminação do subsolo e das águas subterrâneas da Vila Carioca, enquanto a Esso deixou enorme passivo ambiental no bairro da Mooca. 
Em Pinheiros, uma cooperativa está operando em terreno contaminado. Também na Zona Sul da cidade, num terreno de $59 \mathrm{mil} \mathrm{m}^{2}$, na esquina das avenidas Nações Unidas e Interlagos (duas das mais importantes artérias de uma região densamente povoada), está armazenada quase uma tonelada de material radioativo produzido pela Usina Santo Amaro, da extinta Nuclemon. Na Zona Leste, empresas irregulares reciclavam borra de alumínio na região da estrada do Palanque. E, como se tudo isso não bastasse, uma pesquisa comprova que a contaminação do solo no estado de São Paulo é em grande parte provocada pelos tanques dos postos de combustíveis, que há muito tiveram seu prazo de validade vencido.

O polo petroquímico, que 'democraticamente' atinge as cidades de São Paulo, Santo André e Mauá, emite gases que podem provocar alterações no funcionamento da tireoide, afetando particularmente as crianças. Em Mauá, no Condomínio Barão de Mauá, construído sobre o lixão industrial da empresa Magneti Marelli Cofap Autopeças, um operário morreu e um homem sofreu queimaduras que o levaram ao hospital; além disso, segundo avaliações, a qualquer momento pode se repetir a tragédia do Morro do Bumba, em Niterói, cuja encosta, após fortes chuvas, deslizou em abril de 2010, soterrando pelo menos sessenta casas de uma comunidade construída sobre um aterro sanitário desativado na década de 1960. Oficialmente, mais de duzentas pessoas morreram e dezenas ficaram desabrigadas.

A capital paulista aparece, pois, como o município com maior número de conflitos em todo o mapa, com pelo menos 15 casos claramente localizados e, geralmente, restritos a uma área bem reduzida, se comparada às extensões impactadas no Amapá, mantendo o exemplo utilizado no início desta discussão. Pelo mesmo motivo, são operários e trabalhadores da indústria e moradores do entorno de aterros/ou terrenos contaminados as duas categorias que aparecem como população impactada predominante, com uma frequência superior à de qualquer outro estado (44\% e $47 \%$ dos casos do estado, respectivamente). Na verdade, os casos apontados no mapa refletem apenas a ponta do iceberg dos casos de passivos e contaminação ambiental existentes tanto na capital como no estado como um todo. Segundo a Companhia de Tecnologia e Saneamento Ambiental (Cetesb), órgão ambiental estadual, existem no momento 3.675 áreas contaminadas e reabilitadas registradas pelo órgão, e a grande maioria - 2.922 delas - por postos de gasolina (Cetesb, 2010).

Ainda sobre o Sudeste, vale ressaltar outra situação específica, a do Rio de Janeiro. Apesar de compartilhar com São Paulo muitas das dinâmicas socioeconômicas no que diz respeito à urbanização e industrialização, o 
estado do Rio de Janeiro é o terceiro maior em percentual de municípios cobertos pelo mapeamento, atingindo $63 \%$. Isso se explica pela existência de casos relacionados a grandes complexos industriais e portuários, além de desastres químicos ou acidentes ampliados no rio Paraíba do Sul que, como ele, atravessam inúmeros municípios e aumentam radicalmente os territórios afetados onde há indústrias com o potencial de gerar esse tipo de acidente (Freitas, Porto \& Machado, 2000). Além disso, a dinâmica política faz com que muitos conflitos solucionados na capital do estado, como o relacionado à gestão dos resíduos sólidos da Região Metropolitana do Rio de Janeiro e da Baixada Fluminense, igualmente sejam transpostos para outros municípios.

Exemplo disso é o esgotamento do Aterro Controlado de Jardim Gramacho, em Duque de Caxias, e suas graves consequências sobre todo o ecossistema no entorno da baía de Guanabara, como motivador de uma série de outros conflitos. O projeto de instalação de um aterro sanitário em Paciência, na Zona Oeste do município do Rio de Janeiro, foi rejeitado pela população local (já gravemente impactada pela poluição causada por empreendimentos industriais instalados na região), que resistiu durante anos à sua instalação. Dada a urgência do problema e a impossibilidade de contornar a mobilização da população local contra o projeto, este foi transferido para a zona rural de Seropédica, gerando novos conflitos e caracterizando uma tendência de deslocamento dos investimentos ligados a processos ou tecnologias mais perigosas/insalubres para regiões com menor capacidade de mobilização e resistência, tendência essa responsável por inúmeros outros casos de injustiça ambiental (Acselrad, 2004).

A exploração petrolífera na bacia de Campos e empreendimentos correlatos, como a instalação do polo petroquímico de Itaboraí e do Arco Metropolitano, concomitantemente à instalação de um grande projeto logístico-siderúrgico no Norte Fluminense - o Complexo Portuário de Açu -, contribuem ainda mais para a expansão territorial dos conflitos em todo o estado. São casos que caracterizam o atual modelo de desenvolvimento industrial do Rio de Janeiro e atingem dezenas de municípios simultaneamente, quando não se estendem ainda por outro estado, como é caso do porto do Açu, que atinge 32 municípios, grande parte dos quais são pertencentes a Minas Gerais.

Mas é nas Regiões Nordeste, Norte e Centro-Oeste que atualmente se encontra a fronteira de expansão capitalista no Brasil, o que explica o fato de, em média, 30\% dos municípios dos estados dessas regiões terem algum conflito mapeado ou sofrerem impactos indiretos, chegando a índices extremamente elevados no Amapá (100\%), Acre (64\%) e Mato Grosso (61\%). 
Essa diferença se deve a fatores sociais, geopolíticos e à dinâmica econômico-produtiva da expansão capitalista nesses estados. Na Região Amazônica, no Cerrado Nordestino e do Centro-Oeste, e mesmo na zona litorânea de grande parte do Nordeste, o agravamento dos conflitos está relacionado à expansão das fronteiras pecuária e agrícola, da carcinicultura e de empreendimentos relacionados à produção de energia, especialmente por meio de hidrelétricas e pequenas centrais hidrelétricas (PCHs). A mineração, as inúmeras obras de infraestrutura (como rodovias, ferrovias, hidrovias) e grandes projetos de agricultura irrigada, como a transposição do rio São Francisco, completam o quadro.

Com frequência, tais casos envolvem vastos territórios e diversos municípios. Empreendimentos estruturantes, como o asfaltamento da rodovia BR-163, a instalação do gasoduto Coari-Manaus ou a ferrovia LesteOeste, têm potencial para impactar direta ou indiretamente vários estados simultaneamente, de modo a potencializar a área coberta pelo mapeamento.

\section{As Populações Atingidas pelos Conflitos}

Os comentários anteriores explicam em boa parte por que, embora $84 \%$ da população brasileira viva em áreas urbanas (IBGE, 2010), a maioria dos casos levantados neste mapeamento atinge justamente populações e trabalhadores que vivem nos campos, florestas e zonas costeiras (mais de 60\%), ou seja, nas áreas em que as disputas por recursos naturais ligadas à inserção do Brasil no comércio internacional afetam comunidades tradicionais e agrárias. As populações urbanas representam apenas $31 \%$, enquanto pouco mais de $8 \%$ envolvem populações inseridas em territórios não claramente urbanos ou rurais, conforme podemos ver no Gráfico 1.

Gráfico 1 - Distribuição dos conflitos segundo a localização das populações (\%)

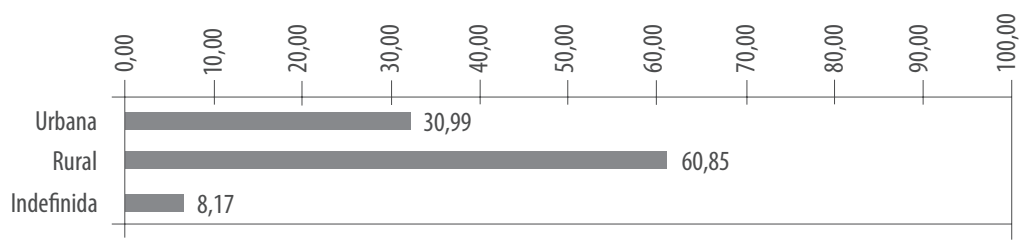

Fonte: Elaborado pelos autores com base nos dados do Mapa de Conflitos Envolvendo Injustiça Ambiental e Saúde no Brasil.

A distribuição preponderante de conflitos na região rural no Mapa de Conflitos tem duas explicações principais: a primeira, relacionada ao item anterior, decorre do fato de a expansão capitalista brasileira estar 
fortemente relacionada à busca por recursos naturais e terra, caso do agronegócio, da monocultura de árvores, da mineração nos ciclos ferro-aço e bauxita-alumínio, e de grandes empreendimentos de infraestrutura, como hidrelétricas, ferrovias, hidrovias, portos e rodovias. Tais casos de injustiça ambiental atingem vastos territórios e inúmeros grupos populacionais, desde indígenas, quilombolas, extrativistas e pescadores, até pequenos agricultores e assentamentos da reforma agrária; o segundo fator importante se refere à atuação dos movimentos por justiça e contra o racismo ambiental no país por parte de populações e entidades ligadas aos povos e comunidades tradicionais, como indígenas, quilombolas, extrativistas e pescadores artesanais, além de movimentos ligados à reforma agrária e à agroecologia.

Apesar de ainda em menor quantidade, aparecem nas cidades vários conflitos típicos de situações de injustiça e de racismo ambiental nos territórios urbanos, como aqueles nas chamadas 'zonas de sacrifício', onde vivem populações pobres e discriminadas em áreas sem saneamento básico e próximas a fábricas poluentes, aterros, ou próximas às encostas ou sob risco de enchentes. A quantidade de denúncias de casos tende a crescer à medida que os movimentos por qualidade de vida, saúde, sustentabilidade e direitos humanos nas cidades se integrem e incorporem em suas lutas os conceitos de direito à cidade e justiça ambiental.

O Gráfico 2 mostra a forma como se dá a distribuição das populações nos conflitos.

À medida que se desenvolve, a luta pelo território determina aqueles que serão por ela atingidos. Entre as populações que vivem nas regiões rurais, ou seja, campos, florestas e zonas costeiras fora dos espaços urbanos, 33,7\% dos conflitos envolvem os povos indígenas. Esses conflitos se tornam mais expressivos se considerarmos que, segundo o Censo Demográfico de 2010, há apenas cerca de 818 mil autodeclarados indígenas no país, ou seja, 0,4\% da população brasileira. Ainda no campo e logo depois dos povos indígenas, temos os agricultores familiares, com quase $32 \%$; os quilombolas, com 21,6\%; os pescadores artesanais, com 14,8\%; os ribeirinhos, com 13,5\%; e os caiçaras, com 3,0\%. Na faixa dos 2\%, estão as marisqueiras e os seringueiros. Entre $2 \%$ e $1 \%$, extrativistas, geraizeiros e quebradeiras de coco babaçu. Abaixo do $1 \%$, encontramos catadores de caranguejos e faxinalenses, entre outros.

Ao correlacionarmos esses dados com a distribuição espacial dos conflitos, verificamos que os agricultores familiares e os povos indígenas são os grupos mais atingidos pelos efeitos do atual modelo de desenvolvimento sobre o equilíbrio ambiental e a saúde coletiva de territórios e populações. Ambos os 
Gráfico 2 - Distribuição dos grupos populacionais nos conflitos apresentados no mapa (\%)

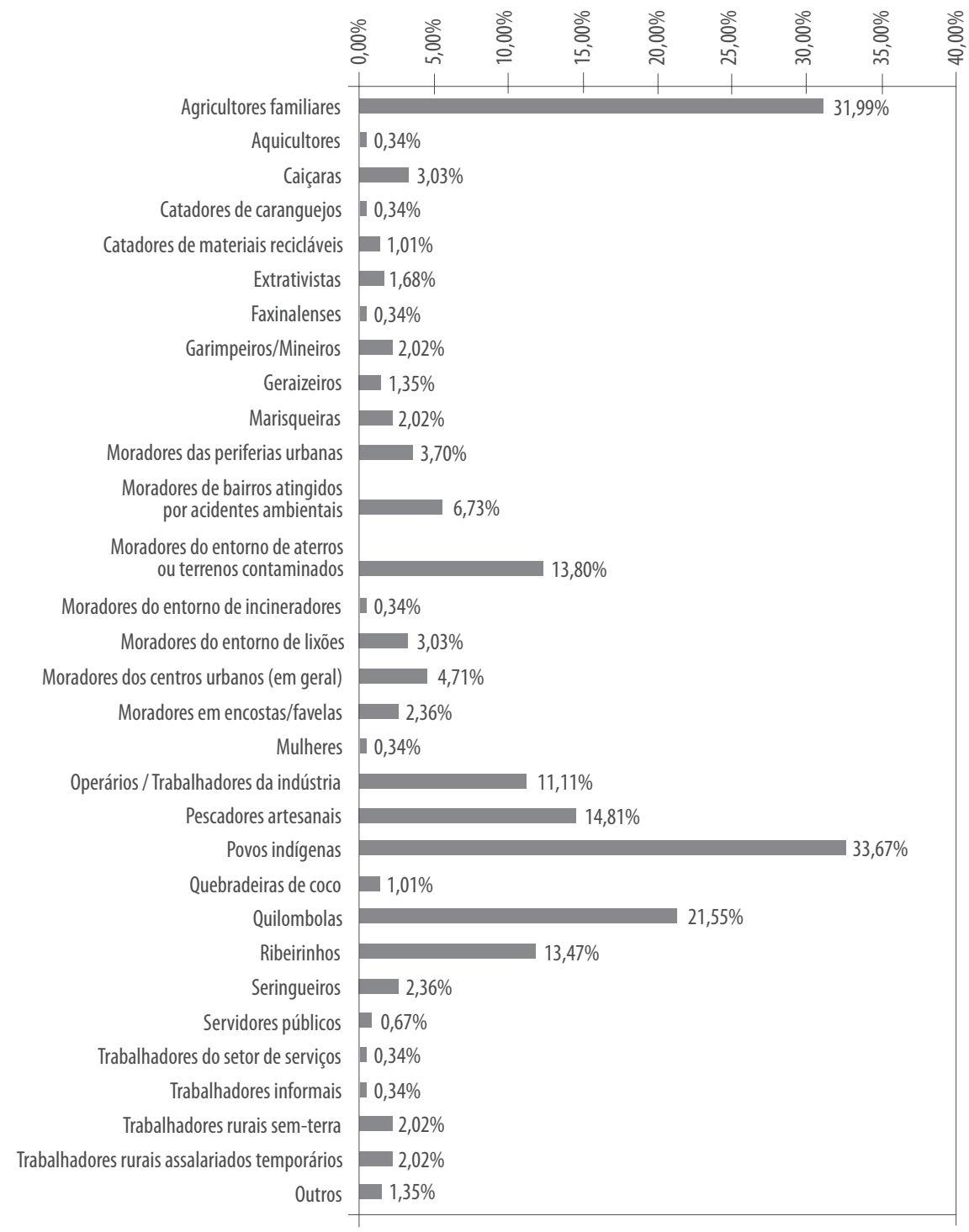

Obs.: Há muitas comunidades que se autoidentificam como pertencentes a mais de um grupo, como, por exemplo, quilombolas que atuam como vazanteiros; agricultores familiares sem-terra; ribeirinhos que sobrevivem também como pescadores artesanais e extrativistas. Da mesma forma, muitas vezes há mais de um dano ambiental, mais de um agravo à saúde e mais de um responsável pelo conflito. Essa sobreposição faz com que os percentuais dos gráficos, se somados, cheguem a mais de $100 \%$.

Fonte: Elaborado pelos autores com base nos dados do Mapa de Conflitos Envolvendo Injustiça Ambiental e Saúde no Brasil. 
grupos são especialmente atingidos nas regiões de expansão do agronegócio na Amazônia, Centro-Oeste e algumas regiões de Minas Gerais, São Paulo, Paraná e Rio Grande do Sul. Nessas regiões, a expansão da fronteira agrícola tem ocorrido de forma sistemática e violenta, não raramente resultando na expulsão das comunidades de seus territórios tradicionais e no assassinato de líderes locais.

Destacam-se em Minas Gerais os conflitos relacionados à construção de barragens e hidrelétricas, ao avanço da monocultura do eucalipto sobre os territórios e aos efeitos danosos da mineração e da transposição do rio São Francisco. Em muitos casos, agricultores e índios são atingidos simultaneamente ou compartilham os efeitos com outras populações, como trabalhadores rurais assalariados, geraizeiros, vazanteiros, quilombolas e outros. Nos demais estados em destaque, especialmente no Mato Grosso, Mato Grosso do Sul e Pará, os mesmos tipos de processos desencadeiam os conflitos, com o diferencial de, nesses estados, o avanço da monocultura da soja e da pecuária ser mais significativo. O Gráfico 2 explicita a forma como na incorporação de vastos territórios à economia globalizada, sob a égide da exploração mecanizada e do monocultivo latifundiário, não se respeitam territórios e fronteiras identitárias. Tais conflitos atingem tambémmesmo que em menor proporção em relação aos dois grupos destacados quilombolas, ribeirinhos, pescadores artesanais, caiçaras, seringueiros, extrativistas, quebradeiras de coco, trabalhadores rurais assalariados e semterra, faxinalenses, entre outras populações.

Mas a luta pelo território não está presente apenas no campo. As informações referentes ao universo urbano são também importantes dentro do mapa. Se deixamos de lado os $11,1 \%$ de operários envolvidos nos conflitos e focalizamos as informações referentes a moradores, veremos que, mesmo nas áreas urbanas, 34,7\% dos casos envolvem diretamente o território, como perceberemos mais detalhadamente no próximo capítulo. Ou envolvem o direito de todos à cidade e à moradia, como expressam bandeiras de parte dos movimentos sociais das metrópoles brasileiras. É interessante mencionar que movimentos por justiça ambiental nas cidades tendem a crescer à medida que mobilizações como as lutas contra a discriminação das favelas e das periferias inóspitas em favor da moradia digna, do saneamento ou do transporte público de qualidade nas periferias, entre outras, são reconhecidas e incorporadas como movimentos por justiça ambiental no país, tal como já ocorre em países como os Estados Unidos (Bullard, 2005). Essa problemática foi assumida como uma das grandes bandeiras de luta pelo GT Combate ao Racismo Ambiental, vinculado à RBJA, desde a sua criação em 2005. 


\section{Principais Atividades Geradoras de Injustiças Ambientais}

Dois grandes grupos de causas de injustiças ambientais aparecem reunidos nesta seção. $\mathrm{O}$ primeiro se refere às atividades econômicas e seus agentes, que, ao interferirem nos territórios e modos de vida das populações, geram inúmeros impactos e conflitos. Tais atividades expressam os principais eixos econômicos que orientam o atual modelo de desenvolvimento brasileiro em sua inserção na economia capitalista globalizada. Dentre eles, destacamse, nesta ordem, o agronegócio, a mineração e siderurgia, a construção de barragens e hidrelétricas, as madeireiras, as indústrias químicas e petroquímicas, as atividades pesqueiras e a carcinicultura, a pecuária e a construção de rodovias, hidrovias e gasodutos.

Também fazem parte desse grupo os 28,7\% inseridos na categoria 'outros', como veremos a seguir. Em tal categoria, aparecem de forma destacada os setores turístico e imobiliário, na disputa territorial em que, sistematicamente, ou se busca expulsar comunidades tradicionais dos locais onde vivem para transformá-los nos 'paraísos ecológicos' dos eco resorts ou, nas áreas urbanas, igualmente se alijam os moradores pobres para favelas, periferias degradadas ou áreas de risco, como encostas de morros ou margens de rios, e acabam por ser acusados de responsáveis pela destruição ambiental e/ou pela violência nas cidades.

Um segundo grupo responsável por injustiças ambientais, entretanto, é de certa forma inesperado e, mais que isso, majoritário. Está associado à atuação, ou melhor, à omissão, à deficiência ou, até, à conivência do poder público e entidades governamentais, inclusive, em muitos casos, o Judiciário e/ou os ministérios e defensorias públicos. Do ponto de vista metodológico, poder-se-ia questionar a presença de dois grupos de atividades distintas de um lado o setor econômico-produtivo e, do outro, setores ou instituições de governo - dentro da mesma categoria de classificação.

Assumimos essa posição respeitando a definição de injustiça ambiental presente na Declaração de Lançamento da RBJA em 2002, quando se define que uma injustiça ambiental pode ser produzida tanto por atividades econômicas quanto pela forma como o Estado deixa de proteger as populações, sejam as atuais ou as gerações futuras, diante de políticas públicas e práticas institucionais que favorecem a geração de injustiças. Assim, embora pareça estranho, a atuação do Estado e das instituições públicas pode desempenhar um importante papel na produção de injustiças e conflitos (Porto \& Pacheco, 2009), e sua agregação às atividades econômicas possibilita refletir, sob o viés político-pedagógico, acerca do papel do Estado e das instituições no atual momento do país. 
Destacamos aqui problemas relacionados à forma como os licenciamentos ambientais são realizados, bem como à morosidade ou deficiência das instituições da justiça em defender os interesses coletivos das populações atingidas. Tais problemas ocorrem em diferentes situações, como os procedimentos para a regulação fundiária, a defesa da saúde indígena ou a atenção básica e estudos que avaliem os impactos dos problemas ambientais sobre ela.

Gráfico 3 - Distribuição das atividades geradoras de injustiças ambientais (\%)

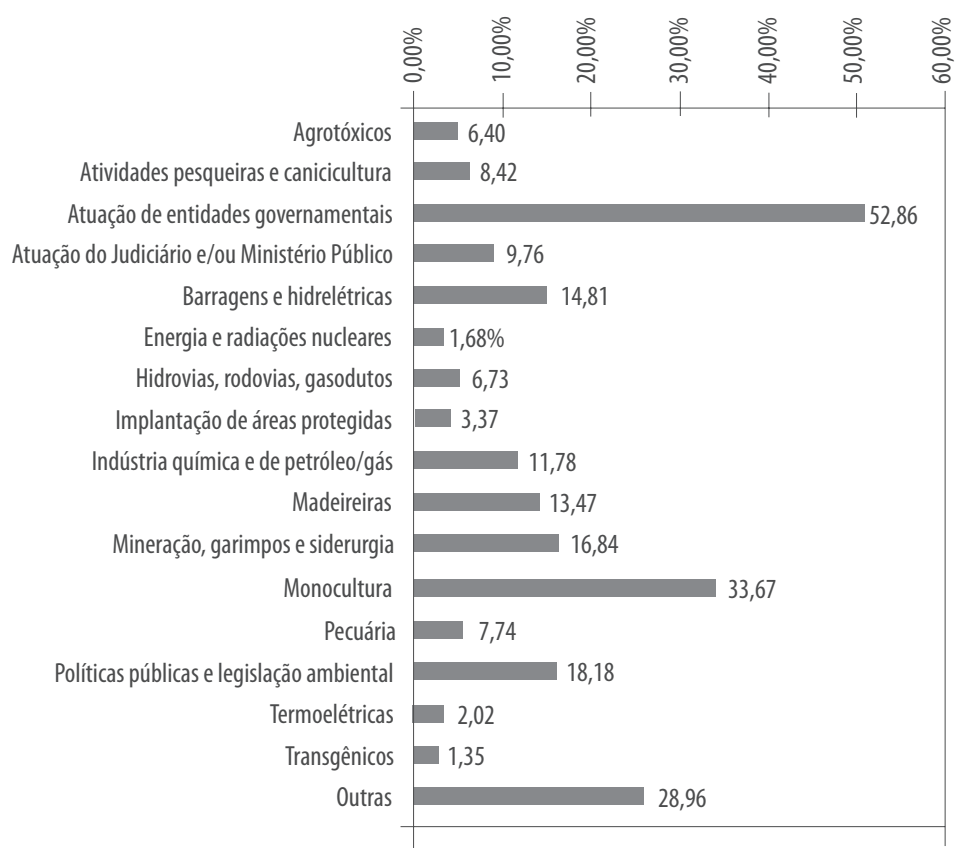

Obs.: Há muitas comunidades que se autoidentificam como pertencentes a mais de um grupo, como, por exemplo, quilombolas que atuam como vazanteiros; agricultores familiares sem-terra; ribeirinhos que sobrevivem também como pescadores artesanais e extrativistas. Da mesma forma, muitas vezes há mais de um dano ambiental, mais de um agravo à saúde e mais de um responsável pelo conflito. Essa sobreposição faz com que os percentuais dos gráficos, se somados, cheguem a mais de $100 \%$.

Fonte: Elaborado pelos autores com base nos dados do Mapa de Conflitos Envolvendo Injustiça Ambiental e Saúde no Brasil.

O conjunto dos dados do Gráfico 3 permite observar que a principal atividade produtiva geradora de injustiça ambiental no Brasil é a monocultura, seja a de árvores (para a produção de papel, celulose ou para a indústria moveleira), seja a de insumos para a produção de agrocombustíveis ou alimentação animal (em especial a soja), passando por alimentos de uso do cotidiano, como feijão, arroz ou laranja, com destaque para as monoculturas de exportação. 
Expandindo-se de norte a sul do país e incentivado pelo crédito rural, o agronegócio é responsável pelos impactos negativos elencados em pelo menos 33\% dos conflitos mapeados. ${ }^{3}$ Entre as principais áreas atingidas, destacam-se: o interior dos estados do Rio Grande do Sul, Santa Catarina, Paraná e São Paulo até o norte do Mato Grosso; o oeste de Rondônia e o Sul do Amazonas; a região conhecida como Bico do Papagaio, na fronteira entre os estados do Pará, Tocantins e Maranhão; o sul da Bahia e o norte do Espírito Santo; e o Cerrado nordestino, especialmente no estado do Piauí. Outras atividades correlatas, como o uso de agrotóxicos, transgênicos, a atividade madeireira e a pecuária somam juntas pelo menos $28 \%$ dos conflitos. Como já citado anteriormente, com esses dados se justifica, em parte, a predominância de casos em áreas rurais verificada em item anterior.

Por sua grande relevância no mapa, destacamos alguns exemplos de conflitos relacionados à luta de povos indígenas, quilombolas, comunidades tradicionais e camponeses contra os monocultivos:

1) Aracruz, Conceição da Barra e São Mateus (ES) - os índios Tupiniquim e os quilombolas da região de São Mateus travam uma luta secular pela preservação de seu território. Desde meados de 1960, enfrentam o poder econômico e político local para garantir a demarcação de suas terras. Parte significativa dessa área esteve sob a ocupação da empresa Aracruz Celulose S.A. (atual Fíbria) até 2007, quando o governo federal finalmente reconheceu que os direitos de indígenas e quilombolas estavam sendo ameaçados pela continuidade da exploração por parte da empresa da área em disputa, a qual passou de fato e de direito à posse das comunidades indígenas da região, corrigindo uma injustiça que perdurava por décadas. Os quilombolas, entretanto, continuam a ter dificuldades para ter seus direitos garantidos.

2) Eunápolis (BA) - desde o início da década de 1990, povos indígenas e pequenos agricultores do sul da Bahia lutam contra o avanço da monocultura do eucalipto sobre suas terras e contra os impactos da supressão da Mata Atlântica nativa e do uso intensivo de agrotóxicos nesse tipo de cultura na qualidade ambiental da região. O processo de retomada das terras indígenas tem gerado atos de violência, represália e assassinatos.

\footnotetext{
${ }^{3}$ Segundo dados do Ministério da Agricultura, Pecuária e Abastecimento, o governo brasileiro, por meio de diversas fontes de financiamento, concedeu mais de $\mathrm{R} \$ 108$ bilhões em crédito rural para a safra 2009/2010. Desse total, pelo menos R\$ 93 bilhões foram concedidos ao agronegócio. Para a safra de 2010/2011, a perspectiva é de que esse montante aumente em pelo menos 7,5\% (Brasil, 2010).
} 
3) Tasso Fragoso, Balsas, Loreto e Alto Parnaíba (MA) - na região de Vão da Salina, Município de Balsas, famílias de pequenos agricultores estão sendo confinadas pelas grandes fazendas de soja e atingidas pelo uso de agrotóxicos e de outras tecnologias empregadas na monocultura da soja. Soma-se a isso o registro de utilização da força de trabalho em condições análogas à escravidão. O Grupo Móvel de Fiscalização de Combate ao Trabalho Escravo da Superintendência Regional do Trabalho e Emprego do Maranhão (SRTE/MA) resgatou em uma fazenda de soja no município de Balsas, em outubro de 2008, nove trabalhadores nessas condições.

4) Vale do Paraíba (SP) - o plantio extensivo de eucalipto no Vale do Paraíba, região leste do estado de São Paulo, está causando graves danos ambientais e êxodo rural. Recursos hídricos, animais e pessoas foram contaminados por agrotóxicos e diversos trabalhadores rurais ficaram desempregados. Organizações sociais, trabalhadores rurais e pequenos produtores rurais estão se mobilizando para deter a expansão do deserto verde. Paradoxalmente, os oligopólios poderosos da indústria de celulose têm obtido financiamentos do Banco de Desenvolvimento Econômico e Social (BNDES).

5) Santarém (PA) - os pequenos produtores rurais da região de Santarém estão sendo expulsos de suas terras com o avanço da soja, além de sofrerem com os danos à saúde causados pelos agrotóxicos usados pela monocultura. Expulsos de suas terras, ribeirinhos e quilombolas migram para as cidades, sem que a infraestrutura local comporte o crescimento populacional. Falta de saneamento básico e atendimento médico, aliada à inflação dos preços dos gêneros alimentícios, são alguns dos efeitos danosos da ocupação do espaço rural pela monocultura, refletidos no meio urbano como uma piora geral da qualidade de vida.

Variando entre 3,3 e 52\%, os conflitos derivados da atuação das diversas instâncias do Estado brasileiro são responsáveis por uma ampla gama de consequências negativas sobre a qualidade de vida, segurança jurídica e alimentar, condições de subsistências e até equilíbrio ambiental dos territórios ocupados por populações vulneráveis no campo, florestas, zonas costeiras e nas áreas urbanas.

Obras públicas ou privadas de infraestrutura, especialmente nos setores de energia e logística, financiadas ou não com recursos públicos, são responsáveis pelo reassentamento forçado e pela destruição dos laços 
comunitários e dinâmicas territoriais de centenas de comunidades no Brasil, principalmente as tradicionais. $\mathrm{O}$ financiamento de atividades poluentes ou degradantes, ou ainda a falta de fiscalização dessas atividades, também geram conflitos e agravos à saúde humana que, geralmente, são justificados em nome do 'desenvolvimento' e da 'geração de empregos'.

De forma aparentemente contraditória, a criação de unidades de conservação de proteção integral é outro foco de conflito, já que impede o acesso de diversas comunidades tradicionais a recursos naturais essenciais à sua subsistência, tornando impossível sua permanência no local onde nasceram e sempre viveram. Essa política preservacionista é fonte de conflitos justamente por desprezar as comunidades tradicionais, tornando-se assim forte fonte de injustiças e de racismo ambiental, como vimos em relação à expulsão dos caiçaras da Estação Ecológica Jureia-Itatins.

Em alguns casos, a criação de unidades de conservação, assim como certas obras de infraestrutura, resulta em reassentamentos forçados e êxodo, contribuindo para a intensificação dos problemas ambientais verificados nas periferias urbanas e para a degradação das condições de vida dessas populações expulsas, que vão se integrar precariamente ao mercado de trabalho informal, geralmente em condições degradantes e de pobreza extrema. O Judiciário e os ministérios públicos desempenham papel significativo nesses conflitos, pois em alguns casos, ao serem acionados por uma das partes envolvidas, omitem-se ou privilegiam direitos privados de certos atores sociais, em detrimento dos direitos coletivos das populações vulneráveis atingidas.

Apresentamos, pois, alguns exemplos de conflitos marcados pelas consequências negativas de determinadas políticas públicas ou práticas institucionais.

1) Serra do Navio (AP) - no Brasil, a torianita é encontrada de forma abundante na região central do Amapá, na bacia do rio Araguari, dentro do Parque Nacional de Tumucumaque. Embora a Constituição Federal de 1988 reserve a exploração de minérios radioativos ao monopólio estatal (mediante a criação das Indústrias Nucleares do Brasil - INB), no Amapá a torianita tem sido explorada, principalmente, por particulares e contrabandistas, que chegam a ganhar mais de U\$300,00 por quilo. O contrabando é facilitado por algumas características físicas do próprio minério e pela omissão de setores do Estado brasileiro em relação à fiscalização, exploração e segurança relacionadas à mineração da 
torianita. Segundo a legislação vigente, a Comissão Nacional de Energia Nuclear (CNEN) é a autarquia federal responsável pela supervisão e fiscalização da atividade nuclear no Brasil, porém sua inércia tem propiciado uma situação de risco ambiental e à saúde dos habitantes locais.

2) Salvador (BA) - localizada na parte central da baía de Todos os Santos, próxima à baía de Aratu, a Ilha de Maré, no município de Salvador, é o lar de diversas colônias de pescadores e marisqueiras e de cinco comunidades quilombolas reconhecidas pela Fundação Cultural Palmares (FCP). Apesar da proximidade com a capital baiana, a ilha ainda sofre com a falta de infraestrutura básica e com o precário atendimento à saúde. Além disso, é vítima dos problemas comuns às comunidades limítrofes à baía de Todos os Santos, ou seja, a contaminação da baía por resíduos industriais e esgoto residencial. A proximidade com o porto de Aratu também sujeita essas comunidades a impactos gerados por acidentes ocorridos com embarcações de transporte de produtos das indústrias químicas e petrolíferas localizadas no centro industrial de Aratu (município de Candeias/BA).

3) Niterói (RJ) - fundada por pescadores em 1886, a aldeia Imbuhy, em Niterói, na Região Metropolitana do Rio de Janeiro, é atualmente palco de uma grave situação de racismo ambiental e injustiça social que tem como principal responsável o Exército Brasileiro, por meio da ação do comando do $8^{\circ}$ Grupo de Artilharia de Costa Motorizado (GACosM), responsável pela manutenção e conservação dos fortes existentes no entorno da aldeia. Toda a área da praia de Imbuhy e as imediações do forte são até os dias atuais consideradas áreas de segurança nacional, e os moradores da aldeia Imbuhy são tratados pelo alto comando da guarnição como invasores tolerados por liberalidade do Exército. Não se reconhecem os direitos civis e humanos mais básicos dessa população, e todas as famílias ali residentes estão sujeitas a um rígido regulamento militar, que cerceia até mesmo seu direito de ir e vir ou de receber visitas de amigos e parentes (todos os moradores devem se identificar e ser revistados ao entrar ou sair, e qualquer visitante só pode ter acesso à aldeia mediante autorização prévia do comando do forte e nome inscrito numa lista elaborada pelo próprio exército). Além disso, utilizam como punição, por desrespeitos à regulamentação vigente, a perda do direito a receber visitas ou de receber assistência médica 
em caso de emergência. A situação é bem semelhante, aliás, à que os quilombolas da Restinga da Marambaia enfrentam em relação à Marinha, como pode ser visto no mapa.

4) Curitiba (PR) - inaugurado em 1989 para receber os resíduos orgânicos domésticos e comerciais do município de Curitiba, o Aterro Sanitário da Caximba chegou a 2008 recebendo 2,4 toneladas de resíduos de 16 municípios da Região Metropolitana de Curitiba e de grandes geradores da região (como hospitais, supermercados, aeroportos e restaurantes). Durante os últimos vinte anos, a Prefeitura Municipal de Curitiba foi processada diversas vezes por má gestão dos resíduos depositados no aterro, o que estaria ocasionando a poluição da bacia do rio Iguaçu pelo chorume não tratado. Localizado em um bairro densamente povoado, o aterro da Caximba tem sido fonte de preocupações para os moradores do seu entorno, que suspeitam que a contaminação seja proveniente do lixo não tratado, e os constantes vazamentos de resíduos do local seja a fonte de diversas doenças que acometem a população do bairro. Há relatos de doenças de pele, doenças renais, abortos espontâneos, casos de câncer, hidrocefalia, doenças respiratórias, além de doenças decorrentes da proliferação de vetores de doenças infecciosas como ratos, mosquitos, moscas e baratas. Por esse motivo, a proposta de construção de um novo aterro, em área contígua ao atual, tem recebido forte oposição dos moradores, que têm tentado impedir a implantação do chamado Sistema Integrado de Processamento e Aproveitamento de Resíduos de Curitiba (Sipar), projetado para substituir o atual aterro sanitário.

\section{Principais Impactos e Danos Ambientais}

Os principais impactos socioambientais se referem à alteração no regime tradicional do uso de solo, bem como a problemas na demarcação de terras indígenas, quilombolas, de comunidades tradicionais ou para a reforma agrária. Tais impactos estão relacionados à disputa por territórios por parte de setores econômicos como o agronegócio, a mineração ou obras de infraestrutura.

Outros impactos de grande importância são a poluição (hídrica, do solo e atmosférica), o desmatamento, problemas no licenciamento ambiental, alteração no ciclo reprodutivo da fauna, invasão ou danos a áreas de proteção ambiental, assoreamento de rios e erosão do solo. A questão do 
licenciamento ambiental é de particular importância, pois se encontra presente em praticamente todos os casos nos quais o que está em jogo é um novo empreendimento econômico, sejam hidrelétricas, siderúrgicas, aterros sanitários, indústrias petroquímicas ou eco resorts turísticos. Geralmente, com as denúncias, evidencia-se a falta de participação e de critérios técnicos vinculados à legislação ambiental e sanitária existente. Embora de menor incidência no mapeamento, o impacto nos territórios urbanos se evidencia em questões como poluição, enchentes, formação de lixões e aterros, acidentes ambientais e regulação fundiária.

Presente em $65,7 \%$ dos conflitos mapeados na primeira fase, o impacto intitulado "alteração no regime tradicional de uso e ocupação do território" é majoritário, seguido pelos diversos tipos de poluição e pela "falta/ irregularidade na demarcação de território tradicional" (40,1\%). Também são relevantes "desmatamento e/ou queimada" (35,3\%), "falta/irregularidade na autorização ou licenciamento ambiental" (24,6\%), "alteração no ciclo reprodutivo da fauna" (23\%) e "invasão/dano à área protegida ou unidade de conservação" (21,6\%) (Gráfico 4).

Esses dados confirmam as tendências verificadas nos itens anteriores, de concentração dos impactos negativos das principais atividades geradoras de injustiça ambiental no Brasil nas comunidades e populações tradicionais, localizadas basicamente no meio rural, e em especial nos estados onde a fronteira agrícola e novas atividades capitalistas avançam sobre áreas até então precariamente inseridas no mercado global de commodities agrícolas ou minerais, petróleo, de energia ou do circuito turístico.

No Amazonas, por exemplo, cerca de 170 famílias de extrativistas e ribeirinhos da Gleba Floresta, no município de Boca do Acre, encontram-se ameaçadas por madeireiros e pecuaristas que estão invadindo as estradas de seringueiras e castanheiras da região - principalmente os seringais Pirapora e Novo Andirá. Sem a regularização do acesso à área tradicionalmente ocupada pelas famílias, elas ficam sujeitas à ação violenta desses invasores. O Estado tem sido acionado, e as comunidades reivindicam ao Instituto Brasileiro do Meio Ambiente e dos Recursos Naturais Renováveis (Ibama) a transformação da área em uma reserva extrativista. Contudo, a omissão do órgão ambiental impede que ocorra efetivamente uma solução, mesmo em se tratando de terras públicas. Isso contribui para o aumento do desmatamento na região e para a deterioração do equilíbrio ambiental.

No Nordeste, o avanço da carcinicultura contribui para a destruição de manguezais, ecossistemas essenciais para a reprodução física e cultural 
Gráfico 4 - Principais impactos e danos ambientais (\%)

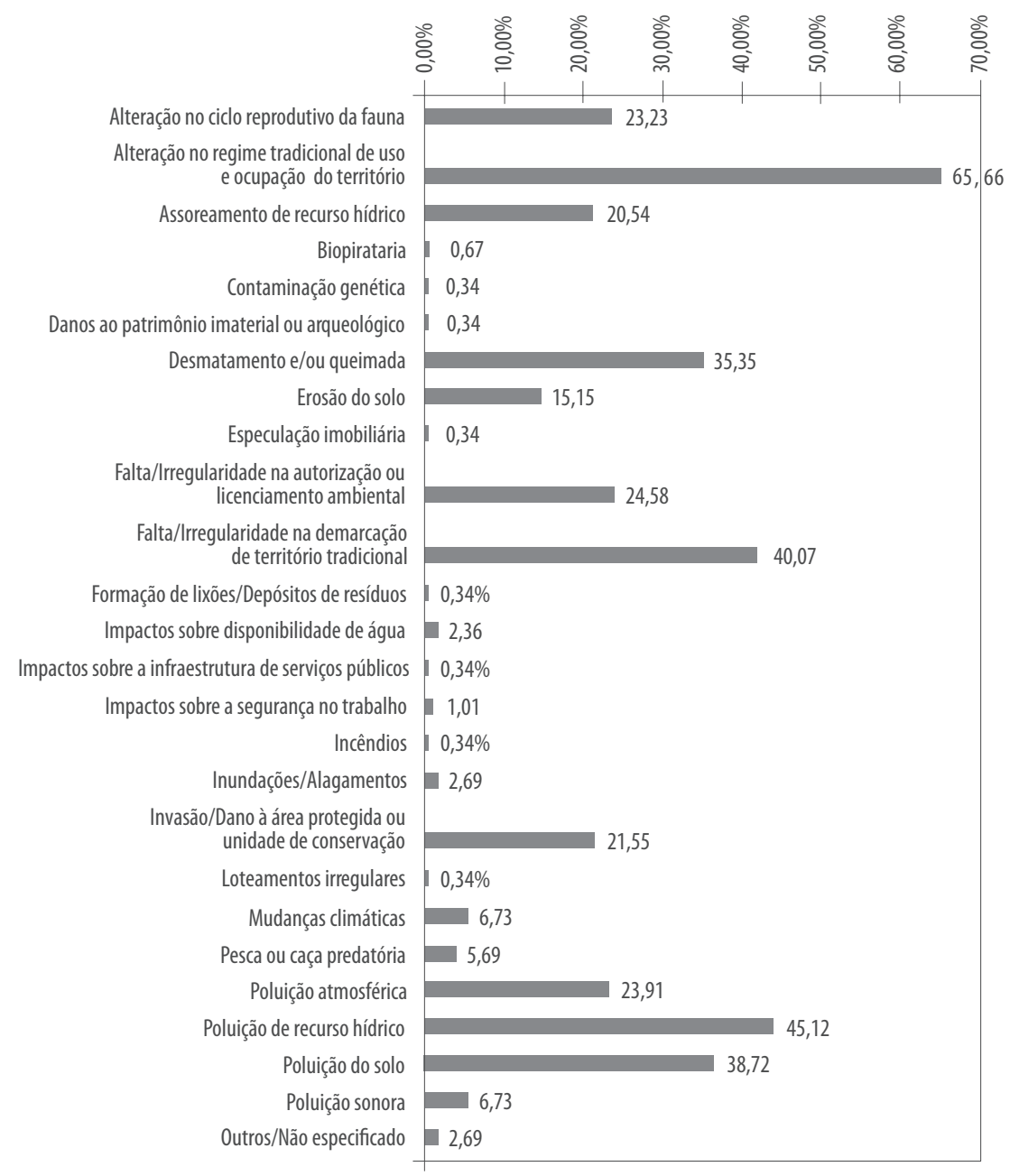

Obs.: Há muitas comunidades que se autoidentificam como pertencentes a mais de um grupo, como, por exemplo, quilombolas que atuam como vazanteiros; agricultores familiares sem-terra; ribeirinhos que sobrevivem também como pescadores artesanais e extrativistas. Da mesma forma, muitas vezes há mais de um dano ambiental, mais de um agravo à saúde e mais de um responsável pelo conflito. Essa sobreposição faz com que os percentuais dos gráficos, se somados, cheguem a mais de $100 \%$.

Fonte: Elaborado pelos autores com base nos dados do Mapa de Conflitos Envolvendo Injustiça Ambiental e Saúde no Brasil.

das comunidades tradicionais costeiras, já que são criadouros de peixes e crustáceos. Na região de Cascavel, no Ceará, por exemplo, os moradores da comunidade de Barra Velha estão sendo atingidos pelos danos da 
carcinicultura. Existem relatos de que o proprietário do empreendimento estaria, com essa atividade, inviabilizando o transporte público que atende à comunidade e, especialmente, bloqueando o indispensável acesso aos recursos do mar, para sustento e reprodução das atividades tradicionais de sobrevivência dos moradores. Técnicos do Ibama e de órgãos ambientais locais observaram uma série de impactos ambientais graves na região, relacionados à criação de camarão em cativeiro.

Em São Félix do Xingu, no Pará, é a exploração de jazidas de níquel pela Companhia Vale do Rio Doce (atual Vale) que expulsa milhares de famílias de pequenos produtores rurais de suas terras. Cerca de 7.400 hectares foram transferidos para a mineradora por intermédio da atuação da superintendência local do Instituto de Nacional de Colonização e Reforma Agrária (Incra). Como consequência, muitas famílias vão engrossar o contingente de miseráveis da periferia do município. Além disso, a instalação da nova planta de extração e beneficiamento de níquel está causando poluição das grotas e igarapés que vêm sendo assoreados e contaminados com os resíduos que descem das serras e das barragens de contenção de rejeitos, onde a empresa desenvolve suas atividades.

Além dos impactos já analisados, exemplificados por esses casos, outro dado que chama a atenção neste levantamento é a presença de denúncias de mudanças climáticas relacionadas aos impactos negativos das atividades geradoras em pelo menos $6,73 \%$ dos casos mapeados. A se considerar que este ainda é um debate relativamente recente, e cuja pesquisa ainda é incipiente na maioria dos casos, pode-se sugerir que este índice seja, na realidade, maior. Isso significa que as consequências negativas do modelo de desenvolvimento estimulado no Brasil sobre o clima não são um assunto para o futuro, como geralmente aparece nos discursos de políticos, técnicos e empreendedores, mas um problema que deve ser encarado de imediato.

\section{Principais Danos e Riscos à Saúde}

O conceito de risco e/ou danos à saúde se refere, como já dito, a uma concepção ampliada de saúde, que reflete não somente a dimensão biomédica dos impactos ambientais, mas questões relacionadas à qualidade de vida, à cultura e tradições, aos direitos humanos e à capacidade de organização e mobilização coletivas. Em relação à tipologia construída em oficina de elaboração do instrumento com membros da RBJA e especialistas em saúde coletiva, optou-se pelo uso de categorias simplificadas com espaço para identificar eventuais patologias específicas possíveis ou potencialmente 
relacionadas ao conflito de acordo com suspeitas ou denúncias das comunidades atingidas ou organizações parceiras.

Definiu-se essa opção na oficina visando a facilitar a compreensão inicial do conflito, mas também para destacar um conceito ampliado de saúde que permitisse entender os problemas centrais em diversas situações de injustiça ambiental como assuntos da saúde. Portanto, não se trata de uma classificação de tipos de patologias específicas, mas sim de problemas de saúde compreendidos sob a lógica da justiça ambiental e dos movimentos sociais.

Além de problemas de saúde clássicos, como doenças crônicas e transmissíveis, existem alguns relacionados a causas externas, como acidentes e suicídios; destacamos três problemas de saúde: as várias formas de violência que conectam a saúde ao campo dos direitos humanos e da democracia; o da soberania alimentar, já que muitos conflitos nos campos e florestas resultam na insegurança alimentar; e o tema da qualidade de vida, pois inúmeros conflitos resultam de discursos que apresentam o progresso e o crescimento econômico como principal benefício, desrespeitando visões dos povos indígenas, quilombolas, comunidades tradicionais e campesinos em sua relação com a natureza, o território e o sentido do que seja bem viver.

$\mathrm{O}$ resultado permite perceber a piora na qualidade de vida como o principal problema de saúde levantado pelas populações atingidas em suas lutas. Trata-se de um sentimento subjetivo, que tem em sua raiz a percepção de que elementos fundamentais para a vida das comunidades em seus territórios foram, estão ou serão impactados negativamente. Tais elementos expressam inúmeras dimensões da vida, como a saúde, a relação com a natureza e o uso de recursos naturais, a identidade e a cultura, o exercício democrático na defesa dos direitos fundamentais e no uso do território em que vivem.

O que está em jogo nesse caso não é apenas a evitação dos prejuízos decorrentes de certos impactos ambientais, como a poluição, mas a manutenção de valores, tradições, práticas sociais e relações com a natureza que foram ou serão perdidos diante do 'progresso' econômico no aproveitamento de recursos naturais e da disputa por território. Portanto, o conceito de qualidade de vida representa uma visão complexa que rejeita a ideia de crescimento, riqueza e consumismo à custa da perda dos próprios valores e sentidos de vida comunitários, em especial nos povos das florestas, cuja subsistência depende da vitalidade de campos e regiões onde os ecossistemas se encontram mais preservados. 
Outra questão de grande importância é a violência como problema de saúde em suas várias formas: desde a coação e ameaça até os assassinatos. Ponto fundamental da pauta dos direitos humanos no Brasil, ela reflete a forma como as populações atingidas e vulnerabilizadas sofrem com a falta de cidadania, principalmente pela impossibilidade de exercerem o direito à organização coletiva para reivindicar e protestar contra as injustiças que contra elas são cometidas. Os casos de assassinatos ou ameaças ocorrem não somente nas regiões mais afastadas dos centros urbanos e, principalmente, no Norte e Nordeste, mas também próximo às grandes metrópoles do Sudeste, como o Rio de Janeiro.

Outras questões básicas de saúde se referem aos problemas da insegurança alimentar, de doenças não transmissíveis (como o câncer e as doenças respiratórias decorrentes da poluição química), dos acidentes e, atrelados a todos esses, da falta de assistência médica adequada e de estudos que os associem aos problemas ambientais na região. As doenças crônicas apontadas estão relacionadas às múltiplas formas de exposição aos poluentes, como agrotóxicos e substâncias químicas de indústrias ou depósitos de resíduos.

O tema da soberania alimentar (istoé, do direito dos povos e comunidades a produzir, comercializar e consumir seus alimentos de acordo com sua cultura e modo de vida, garantindo tanto o seu sustento como sua reprodução social e a preservação da natureza e da sua saúde) e da desnutrição surge como relevante em vários territórios rurais, indígenas e quilombolas, muitas vezes afetados por atividades voltadas para a produção de alimentos para exportação, as chamadas commodities agrícolas. Também o agravamento das doenças transmissíveis pela degradação ambiental e falta de saneamento básico aparecem de forma relevante nos conflitos. Outro aspecto importante, diretamente relacionado à qualidade de vida, é o sentimento de desamparo, expresso pela falta de atenção médica por parte do sistema de saúde, seja para com os povos originários e comunidades tradicionais vulnerabilizados, seja para com as comunidades expostas a diversos perigos (Gráfico 5).

Alguns exemplos de impactos negativos sobre a saúde das populações verificados no mapeamento:

1) Macapá (AP) - Como em muitas outras cidades brasileiras, a população mais pobre de Macapá sofre com um grave problema: a falta de saneamento básico. Problema comum a cerca de $60 \%$ da população amapaense, a falta de água tratada em grande parcela da capital do estado tem contribuído para a permanência da proliferação de doenças relacionadas à ingestão de água 
Gráfico 5 - Danos e riscos à saúde registrados no mapa (\%)

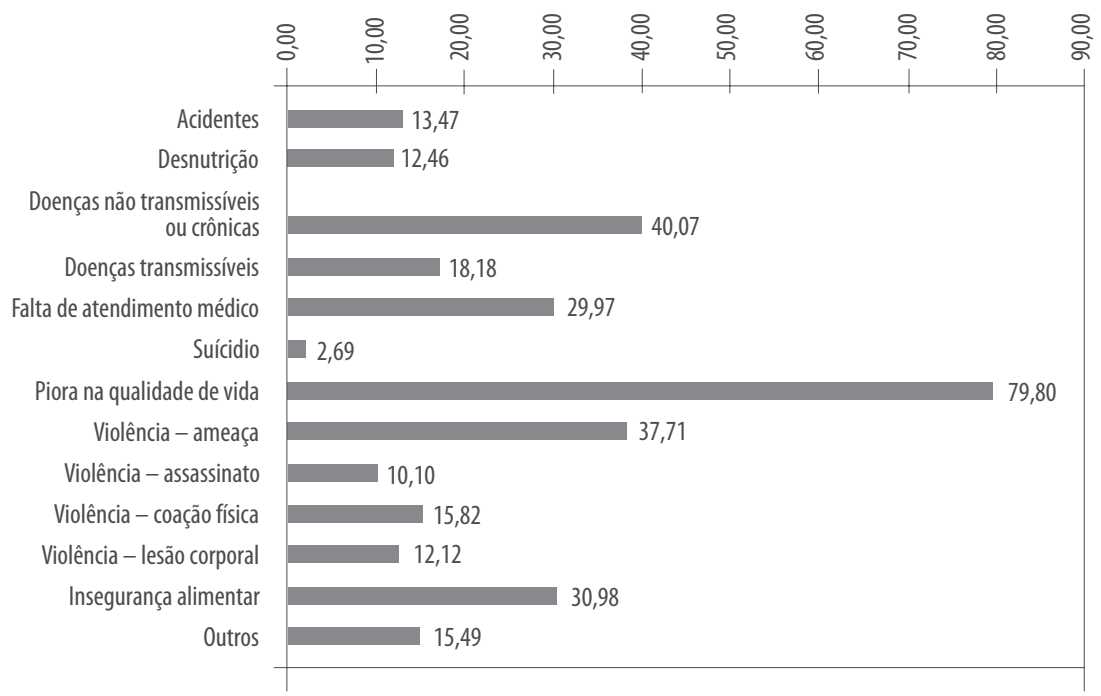

Obs.: Há muitas comunidades que se autoidentificam como pertencentes a mais de um grupo, como, por exemplo, quilombolas que atuam como vazanteiros; agricultores familiares sem-terra; ribeirinhos que sobrevivem também como pescadores artesanais e extrativistas. Da mesma forma, muitas vezes há mais de um dano ambiental, mais de um agravo à saúde e mais de um responsável pelo conflito. Essa sobreposição faz com que os percentuais dos gráficos, se somados, cheguem a mais de $100 \%$.

Fonte: Elaborado pelos autores com base nos dados do Mapa de Conflitos Envolvendo Injustiça Ambiental e Saúde no Brasil.

contaminada, a exemplo da hepatite, cólera, diarreia e dengue. Além da falta de água potável em muitos bairros, a falta de saneamento básico se alia a soluções improvisadas para captação de água e despejo de esgoto, geralmente no próprio rio (de onde parte da população local retira a água que consome) e na orla de Macapá. Para piorar, os macapaenses sofrem as precárias condições dos serviços públicos de atendimento médico-hospitalar, e na capital apenas um pronto-socorro funciona 24 horas/dia para atender à população de 344 mil pessoas. E os postos de saúde nem sempre funcionam. Segundo levantamento da Companhia de Água e Esgoto do Amapá (Caesa), quatro de cada dez pessoas não têm acesso à água potável e apenas quatro de cada cem pessoas têm acesso à rede de esgoto. Essa situação é ainda mais grave nos bairros da periferia, onde a infraestrutura é mais precária.

2) Vale do Javari (AM) - Espalhados por imensas áreas de florestas, rios e igarapés, os povos indígenas dessa região estão sujeitos não apenas às doenças infecciosas e parasitárias, mas também às 
trazidas pelo contato forçado com as populações não indígenas. Depois de décadas de lutas pela demarcação de suas terras, esses povos agora se veem ameaçados de extinção por doenças como hepatite A, B, C e Delta e malária. Também relevante é o câncer de fígado, consequência da hepatite medicamentosa decorrente da contínua ingestão do quinino usado para combater os frequentes episódios de malária, meningite e tuberculose. Apesar das recorrentes denúncias e campanhas promovidas por entidades indígenas locais, e das também frequentes promessas governamentais, a Fundação Nacional de Saúde (Funasa) e o Ministério da Saúde (MS) ainda não conseguiram implementar uma política de saúde indígena eficiente para o atendimento a estes povos. Enquanto isso, as mortes por doenças passíveis de prevenção se sucedem nas aldeias, e proliferam estatísticas alarmantes, como a que informa que cerca de $90 \%$ da população indígena do vale do Javari já contraíram a malária.

3) São Mateus do Sul (PR) - a Unidade de Negócio da Industrialização do Xisto (UN-SIX) da Petrobras em São Mateus do Sul tem sido alvo de críticas e ações de entidades ambientalistas da região por estar ocasionando a contaminação dos rios da bacia do rio Iguaçu com resíduos altamente tóxicos e colocando em risco a saúde da população local. Desde 2004, a empresa já foi alvo de pelo menos duas ações civis públicas promovidas pela Associação de Defesa do Meio Ambiente Araucária (Amar) e pela Defensoria da Água, ligada à Conferência Nacional dos Bispos do Brasil (CNBB). Além disso, em 2006, a empresa já foi multada em R 200 mil pelo Instituto Ambiental do Paraná (IAP) em consequência do derramamento de cerca de 30 mil litros de água contaminada por resíduos tóxicos no rio Canoas. Contudo, a falta de informações sobre os problemas de saúde e de ações concretas continuam a preocupar as populações atingidas e várias organizações parceiras.

\section{Principais Parceiros e Apoiadores dos Atingidos}

Dentre as entidades que atuam como parceiros das populações atingidas na defesa de seus direitos, destacam-se as ONGs (56,6\%) que militam no campo da justiça ambiental, integrando as dimensões sociais, políticas e ambientais, em oposição às estritamente ambientalistas, que dissociam a proteção ambiental da luta pela democracia e os direitos humanos (Gráfico 6). 
Gráfico 6 - Parceiros e apoiadores dos atingidos (\%)

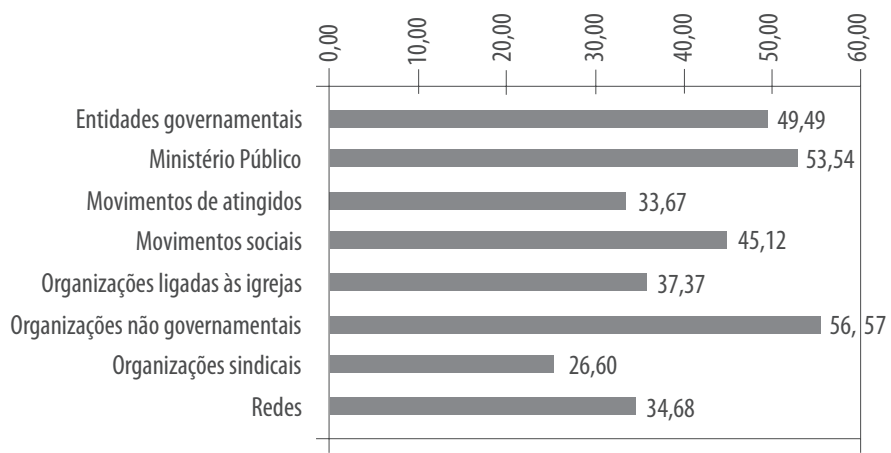

Obs.: Há muitas comunidades que se autoidentificam como pertencentes a mais de um grupo, como, por exemplo, quilombolas que atuam como vazanteiros; agricultores familiares sem-terra; ribeirinhos que sobrevivem também como pescadores artesanais e extrativistas. Da mesma forma, muitas vezes há mais de um dano ambiental, mais de um agravo à saúde e mais de um responsável pelo conflito. Essa sobreposição faz com que os percentuais dos gráficos, se somados, cheguem a mais de $100 \%$.

Fonte: Elaborado pelos autores com base nos dados do Mapa de Conflitos Envolvendo Injustiça Ambiental e Saúde no Brasil.

Também se destacam entidades governamentais (49,5\%) e ministérios públicos (53,5\%), principalmente aqueles que valorizam a articulação com populações atingidas e a participação democrática em seus recursos humanos e políticas de atuação.

A existência de movimentos sociais organizados (45,1\%) e as organizações de populações atingidas (33,7\%) também contribuíram expressivamente para o desenrolar do conflito. Cabe ainda destacar o papel das redes (36,7\%), das organizações ligadas às igrejas (37,4\%) e das organizações sindicais $(26,6 \%)$ como apoiadores dos atingidos.

A pequena participação das organizações sindicais nesses conflitos - se comparada a outras classes de parceiros e apoiadores - denota uma dificuldade da estrutura sindical em incorporar as lutas por melhores condições no ambiente de trabalho em sua agenda de reivindicações. Nesse sentido, os sindicatos de trabalhadores rurais estão presentes nos conflitos socioambientais com muito mais frequência do que seus congêneres da indústria ou do setor de serviços. Em alguns casos, como o conflito em torno das doenças ocupacionais que sofrem ex-funcionários da Aracruz Celulose, em São Mateus (ES), acusam-se lideranças sindicais de articular atos de violência contra lideranças locais em apoio às empresas, muitas vezes sob a justificativa de manutenção dos postos de trabalho.

Nesse mesmo contexto, entidades nacionais representativas das populações rurais, como a Via Campesina, o Movimento das Mulheres Camponesas 
(MMC) e o Movimento dos Pequenos Agricultores (MPA) se articulam com os trabalhadores e populações locais na luta pela promoção da justiça social e reforma agrária no campo.

Casos como esse demonstram como os chamados 'novos movimentos sociais' vêm fortalecendo suas articulações e redefinindo suas bandeiras desde meados dos anos 1980, criando fatos novos num cenário de enfraquecimento dos movimentos sociais tradicionais, como o movimento sindical. Apesar da incorporação do discurso ambiental, da sustentabilidade e da promoção do equilíbrio socioambiental no discurso de muitas entidades de classe, no cotidiano dos conflitos socioambientais mapeados por este projeto, são as entidades ambientalistas, os movimentos de defesa dos direitos humanos, os movimentos pela reforma agrária, as associações de moradores, setores progressistas das igrejas e de entidades governamentais que fortalecem a luta de comunidades e povos atingidos pelas externalidades do atual modelo de desenvolvimento e apropriação dos recursos naturais.

Salvo raras exceções, como se observou no Gráfico 6, representadas por alguns sindicatos rurais e de setores industriais, a temática da justiça ambiental e da equidade em saúde ainda foi pouco incorporada pelas entidades representativas das classes trabalhadoras, representadas principalmente por entidades ligadas às instâncias territoriais (como um bairro, um bioma ou um quilombo) ou à afirmação de identidades e direitos coletivos. 


\section{Referências}

ACSELRAD, H. Justiça ambiental: ação coletiva e estratégias argumentativas. In: ACSELRAD, H., HERCULANO, S. \& PÁDUA, J. A. (Orgs.). Justiça Ambiental e Cidadania. 2. ed. Rio de Janeiro: Relume Dumará, Fundação Ford, 2004.

BRASIL. Ministério da Agricultura, Pecuária e Abastecimento. Crédito rural total: programação e aplicação de recursos nas safras 2009/2010 e 2010/2011, 2010. Disponível em: <www.agricultura. gov.br/portal/page/portal/Internet-MAPA/pagina-inicial/vegetal/estatisticas $>$. Acesso em: 30 maio 2011.

BULLARD, R. The Quest for Environmental Justice: human rights and the politics of pollution. San Francisco: Sierra Club Books, 2005.

COMPANHIA AMBIENTAL DO ESTADO DE SÃO PAULO (CETESB). Relação de áreas contaminadas e reabilitadas no estado de São Paulo. Texto explicativo. São Paulo, 2010.

FREITAS, C. M.; PORTO, M. F. S. \& MACHADO, J. M. H. Acidentes Industriais Ampliados: desafios e perspectivas para o controle e prevenção. Rio de Janeiro: Editora Fiocruz, 2000.

FREUNDENBERG, W. R.; GRAMLING, R. \& DAVIDSON, D. J. Scientific certainty argumentation methods (SCAMs): science and the politics of doubt. Sociological Inquiry, 78(1): 2-38, 2008.

FUNTOWICZ, S. \& RAVETZ, J. Emerging complex systems. Futures, 26(6): 568-582, 1994.

INSTITUTO BRASILEIRO DE GEOGRAFIA E ESTATÍSTICA (IBGE). Censo 2010: população do Brasil é de 190.732.694 pessoas. Resultados do Censo 2010. Disponível em: <www.ibge.gov. br/home/presidencia/noticias/noticia_visualiza.php?id_no ticia=1766\&id_pagina=1>. Acesso em: 30 maio 2011.

IRWIN, A. Citizen Science. London: Routledge, 1995.

KUHN, T. A Estrutura das Revoluções Científicas. São Paulo: Perspectiva, 1987.

MARTINEZ-ALIER, J. Social metabolism, ecological distribution conflicts, and languages of valuation. Capitalism Nature Socialism, 20(1): 58-87, 2009.

MICHAELS, D. Manufactured uncertainty: protecting public health in the age of contested science and product defense. Annals of the New York Academy of Sciences, 1.076: 149-162, 2006.

PACHECO, T. Mapa de Conflitos Causados pelo Racismo Ambiental no Brasil, 2007. Disponível em: <www.fase.org.br/projetos/clientes/noar/noar/UserFiles/17/File/Microsoft $\% 20 W$ ord $\% 20$ -\%20MAPA_DO_RACISMO_AMBIENTAL_NO_BRASIL.pdf $>$. Acesso em: 30 maio 2012.

PACHECO, T. Racismo ambiental urbano: a violência da desigualdade e do preconceito. Rio de Janeiro: Fase, 2009.

PACHECO, T. Terra e território à luz do Mapa da Injustiça Ambiental e Saúde no Brasil. Tempo e Presença Digital, 21(5), 2010. Disponível em: <www.koinonia.org.br/tpdigital/detalhes. asp?cod_artigo=396\&cod_boletim=22\&tipo=Artigo $>$. Acesso em: 30 maio 2011.

PORTO, M. F. Uma Ecologia Política dos Riscos: princípios para integrarmos o local e o global na promoção da saúde e da justiça ambiental. Rio de Janeiro: Editora Fiocruz, 2007.

PORTO, M. F. \& PACHECO, T. Conflitos e injustiça ambiental em saúde no Brasil. Tempus Actas em Saúde Coletiva, 4(4): 26-37, 2009.

WING, S. Environmental justice, science and public health. Environmental Health Perspectives, 113(8-1): 54-63, 2005. 


\title{
2
}

\section{A Iniludível e Desumana Prevalência do Racismo Ambiental nos Conflitos do Mapa}

\author{
Tania Pacheco
}

Cristiane Faustino

Se algumas pessoas são consolidadas no imaginário social como portadoras de humanidade incompleta, torna-se natural que não participem, igualitariamente, do gozo pleno dos direitos humanos.

Sueli Carneiro

P retendemos analisar aqui as formas como, nas disputas pelo território e em torno dos direitos socioambientais, as desigualdades e as nificativamente quem são os injustiçados e quem são os privilegiados. Tomamos como base os dados do mapa em debate neste livro - Mapa de Conflitos Envolvendo Injustiça Ambiental e Saúde no Brasil (ou Mapa de Conflitos) ${ }^{1}$ e, como referência, o conceito de racismo ambiental, inicialmente estabelecido pelo movimento negro dos Estados Unidos, na década de 1980, para explicitar a dimensão racista dos problemas ambientais naquele país. Trabalharemos com o conceito, entretanto, tal como ele tem sido acionado desde sua ampliação nas décadas subsequentes e da forma como foi apropriado e reformulado entre nós, ao relê-lo à luz da realidade brasileira e das lutas por justiça social e ambiental. ${ }^{2}$

\footnotetext{
${ }^{1}$ Disponível em: <www.conflitoambiental.icict.fiocruz.br>.
}

${ }^{2}$ Ver a esse respeito, entre outros, os artigos "Desigualdade, injustiça ambiental e racismo: uma luta que transcende a cor" (Pacheco, 2007) e "Combate ao racismo ambiental: uma luta justa por justiça ambiental" (Faustino, 2012). 


\section{Racismo e Etnocentrismo no Brasil: algumas notas}

Como ponto de partida desta releitura, entendemos que, para falar de racismo ambiental no Brasil, é preciso reconhecer a questão racial e o etnocentrismo como problemas centrais do cenário brasileiro no qual se inserem os grupos sociais envolvidos nos conflitos. Tal reconhecimento permite caracterizar a problemática racial e étnica tanto como fator de produção das injustiças que tais grupos enfrentam quanto como elemento da constituição dos poderes políticos, econômicos e culturais dominantes, que controlam a implementação e o funcionamento das atividades econômicas geradoras desses conflitos.

Assumir essa visão não é, entretanto, algo fácil na nossa cultura. Como ressaltam Felipe González Morales e Jorge Contesse Singh (Ceja/OEA, 2004), ao contrário dos Estados Unidos, onde, após o término da escravidão, mantiveram-se políticas oficiais de segregação até a metade do século XX, no Brasil prevaleceram a omissão do Estado e a 'mistura racial' - detalhada mais adiante -, o que conduziu à falsa ideia da inexistência do racismo, ou, no máximo, como pretendem alguns, como manifestação da influência estrangeira, trazida pela introdução de uma economia capitalista de influência norte-americana.

Esta visión predominante ha sido denominada como 'democracia racial'. Conforme a esta teoría, la brasileña es una sociedad integrada racialmente, en la que, si bien existen prácticas discriminatorias, estas tienen su origen en diferencias sociales o de clase y no en consideraciones de carácter racial. Siguiendo este argumento, las personas negras pobres resultarían discriminadas por el hecho de ser pobres pero no propiamente por el hecho de ser negras.

Esta perspectiva también ha conducido a que aquellos que denuncian prácticas racistas sean a menudo, a su vez, calificados como racistas ellos mismos, por llamar la atención sobre una cuestión sobre la que nadie más lo hace (y que, se supone, no hacen por no ser racistas). (Ceja/OEA, 2004: 6)

Contudo, é necessário reconhecer, como o fazem diferentes autores e autoras das ciências sociais e humanas, especialmente a partir dos anos 1970, e como contraponto às produções que defendiam a ideia de democracia racial (Guimarães, 2004), que, na formação da sociedade brasileira, povos indígenas, negros e suas ascendências sempre estiveram e continuam situados de forma desprivilegiada. Como atesta o relatório "Além do racismo", elaborado por estudiosos da questão racial no Brasil, África do Sul e Estados Unidos:

O Brasil, primeira colônia a escravizar os africanos (em 1538) e última a abolir a escravidão (em 1888), não tomou nenhuma medida para cuidar de sua 
vasta população de ex-escravos e seus descendentes, miseráveis e analfabetos. Buscando uma identidade nacional alinhada com Portugal, seu senhorio dos tempos coloniais, e também com o restante da Europa, o governo e as elites dirigentes do Brasil cultivavam uma sociedade marcada pelos signos da cor e fundamentada em distinções de classe, em que os brancos monopolizavam as posições de poder. Tanto africanos como indígenas eram uniformemente pobres e sem voz. (The Southern Education Foundation, 1999)

Em que pese o determinismo biológico que marcou as teorias europeias racistas dos séculos XVIII-XIX que serviram ao imperialismo e ao colonialismo (Bauman, 1993), atualmente é consenso nos estudos sobre a problemática racial que as diferenças relativas à cor, fenótipo e outros aspectos físicos atribuídos à noção de raça não têm qualquer relação com a capacidade, caráter ou 'defeitos' dos indivíduos ou grupos sociais. No entanto, incutir e manter no senso comum ideias e práticas racistas continua a ser de extrema utilidade para o sistema capitalista.

Negar a existência da raça biológica não pode significar desconsiderar as diferenças inerentes aos indivíduos e grupos sociais que levaram à construção equivocada ou deliberada das teorias racistas. Além do determinismo biológico, pelo qual se justificou a inferioridade dos brasileiros 'não brancos' (Pacheco, 2007) ou a sua inclusão subordinada na democracia racial (Seyferth, 2003), a 'raça social', mediada pelas características físicas e práticas culturais, está presente e faz parte do cotidiano brasileiro. Kebengele Munanga, reconhecendo o caráter etnossemântico, político-ideológico e não biológico da noção de 'raça social', afirma que:

Se na cabeça de um geneticista contemporâneo ou de um biólogo molecular a raça não existe, no imaginário e na representação coletivos de diversas populações contemporâneas existem ainda raças fictícias e outras construídas a partir das diferenças fenotípicas como a cor da pele e outros critérios morfológicos. É a partir dessas raças fictícias ou 'raças sociais' que se reproduzem e se mantêm os racismos populares. (Munanga, 2003)

Embora perfilhemos com autores que identificam as origens do racismo como anteriores à modernidade (Bobbio, Matteucci \& Pasquino, 1986; Seyferth, 2003), Bauman nos ajuda a estabelecer que, na modernidade, o racismo é uma 'demanda':

como concepção de mundo e, mais importante, como instrumento efetivo de prática política, o racismo é impensável sem o avanço da ciência moderna, da tecnologia moderna e das formas modernas de poder estatal. Como tal, o racismo é estritamente um produto moderno. A modernidade tornou possível o racismo. Também criou uma demanda de racismo; uma era que declarava o ganho a única medida do valor humano precisava de uma teoria da imputação para redimir as preocupações com o traçado e a guarda de fronteiras nas novas condições em 
que cruzar fronteiras era mais fácil do que jamais fora. O racismo, em suma, é uma arma inteiramente nova usada na condução de batalhas pré-modernas ou pelo menos não exclusivamente modernas. (Bauman, 1993: 83)

Assim, embora discordemos do autor em termos históricos, ousamos afirmar que não é o fato de pertencerem às 'classes subalternas' que faz com que os seres humanos se transformem em indígenas, negros etc. Na verdade, $\mathrm{o}$ que acontece na maioria dos casos é o reverso dessa equação. No entanto, a negação da discriminação faz com que, muitas vezes, as desigualdades raciais sejam tratadas apenas como consequência das desigualdades de classe, sonegando do debate público as diferentes formas de interdição cotidiana, às pessoas negras, indígenas ou não brancas, da participação política, econômica e cultural, autônoma e em iguais condições. E esse 'sonegar' não é somente mérito das elites ou do senso comum instituído. Está igualmente presente em boa parte dos sujeitos inscritos nas lutas políticas pela transformação social, os quais, muitas vezes com base em uma leitura ortodoxa e míope da realidade, dizem-se parte de uma esquerda marxista.

No caso brasileiro, não se pode perder de vista o processo histórico da colonização. No cotidiano brasileiro, a composição das elites e a distribuição do poder e da riqueza (e, portanto, das classes sociais) sempre estiveram permeadas por desigualdades étnicas e raciais. Nesse percurso, as noções pseudocientíficas sobre raças, exportadas da Europa e incorporadas pelas elites colonizadas, serviram de base para se atestar a superioridade de seus elaboradores, e seus conteúdos saíram "dos círculos intelectuais e acadêmicos para se difundir no tecido social das populações ocidentais dominantes" (Munanga, 2003). A difusão dessas teorias se concretizou na vida real em diferentes formas de violência e exploração sobre as populações inferiorizadas na relação com o modelo europeu, ganhando institucionalidade explícita mais consistente no período posterior à abolição da escravatura, já que na fase escravagista a relação hierárquica senhor-escravo era uma 'circunstância dada', quer de forma naturalizada, quer por meio da força bruta (Jaccoud, 2008). Nos termos dessas teorias e práticas,

os indivíduos de raça 'branca' foram decretados coletivamente superiores aos de raça 'negra' e 'amarela' em função de suas características físicas hereditárias, tais como a cor clara da pele, o formato do crânio (dolicocefalia), a forma dos lábios, do nariz, do queixo etc., que, segundo pensavam, os tornam mais bonitos, mais inteligentes, mais honestos, mais inventivos etc., e consequentemente mais aptos para dirigir e dominar as outras raças, principalmente a negra, mais escura de todas e consequentemente considerada como a mais estúpida, mais emocional, menos honesta, menos inteligente e portanto a mais sujeita à escravidão e a todas as formas de dominação. (Munanga, 2003) 
Se a 'ciência' racista embasou a não inclusão de negros e índios na constituição da 'cidadania brasileira', justificada pela "incapacidade", "malevolência" ou "animalidade" desses grupos e indivíduos, os esforços intelectuais e institucionais da Primeira República se concentraram em produzir o embranquecimento da população até mesmo por meio das políticas de imigração de mão de obra europeia para o exercício do trabalho livre no pós-abolição. Posteriormente, a decantada democracia racial da primeira metade do século $X X$ se baseou numa perspectiva culturalista e de positivização da miscigenação como um 'bem' da nação brasileira.

"Assentada em uma interpretação benevolente do passado escravagista e em uma visão de boa convivência e paz social que caracterizava o Brasil" (Jaccoud, 2008: 55), a falácia da democracia racial logrou escamotear até os dias atuais as desigualdades e discriminações que resultam e estruturam as interdições que a população 'não branca' enfrenta no cotidiano, no exercício do poder político e no acesso à riqueza. Mais que isso, como nos esclarece especialmente o feminismo negro, que tem em Sueli Carneiro um de seus expoentes, no Brasil o mito da democracia racial subestima ou desconsidera o estupro colonial - ou a violação sexual contínua das mulheres negras e indígenas como uma das raízes invisibilizadas da miscigenação da nossa população.

Além do racismo ou da concepção de que as características físicas de um indivíduo ou grupo social estão vinculadas a 'raças' desiguais, com predomínio da branca, a formação da realidade brasileira também está fortemente assentada na ideia de superioridade cultural do elemento branco europeu e pelo etnocentrismo que atribui valores diferenciados e desiguais às diferentes sociedades e culturas (Gomes, 2005). Isso decerto interferiu não só na exploração dos corpos das mulheres e homens 'de cor' para o trabalho braçal (ao qual se somava, no caso das mulheres, a exploração sexual) como também na dizimação, perseguição, endemonização, subordinação e criminalização de suas culturas e tradições. Ainda que esse processo se tenha dado por uma simultânea assimilação mútua no cotidiano, tanto pelo autoritarismo dos grupos dominantes e naturalização de sua superioridade quanto pela resistência dos dominados, essa assimilação nunca significou igualdade de condições políticas, econômicas ou mesmo culturais.

O caráter etnocentrista da formação da nação brasileira também ajuda a entender por que, nos dias atuais, os povos indígenas e as comunidades tradicionais são considerados e tratados como atrasados e estão fadados à transição para a cultura e os modelos desenvolvimentistas que marcam o capitalismo no seu estágio atual. A invisibilização, desvalorização, exotização ou folclorização das diversidades culturais presentes nos diferentes territórios 
têm sido práticas recorrentes na implementação de políticas públicas e atividades econômicas de altos impactos sociais e ambientais. A negação das identidades étnicas ou da capacidade das populações envolvidas nos conflitos de decidirem sobre o destino, gestão e usufruto dos bens ambientais, fortemente atrelados aos seus modos de vida, trabalho, tradições e práticas religiosas ancestrais, verifica-se, por exemplo, no frequente ataque às legislações nacional e internacional que versam ou incidem sobre a autodeterminação dos povos.

Embora nos instrumentais da pesquisa para o mapa em debate não se faça menção à cor, raça ou etnia dos atingidos, supomos que os conflitos urbanos - fartamente explicitados no capítulo 1 - tenham as populações pobres e negras como as principais atingidas. A literatura sobre as injustiças ambientais é particularmente enfática (como se pode notar ao longo deste livro) na constatação de que tais injustiças são marcadas por um forte enlace com as desigualdades sociais, políticas, econômicas e culturais. E, a nosso ver, o tema das desigualdades étnicas e raciais não pode ser subconsiderado, uma vez que

os negros e também os índios são aceitos apenas na condição de marcos da brasilidade, mas não como pessoas (...). A recuperação moral dos negros e índios fica, portanto, reservada ao espaço mitológico. Note-se que apenas enquanto marco, o branco ocupa a posição limiar ao negro e ao índio: em termos substantivos e culturais, o branco continua referido e pensado como superior, ou seja, capaz de maior civilização e detentor de poder e riqueza. O Brasil continua, certamente, se vendo a partir dos olhos dos brancos estrangeiros: europeu e americanos. Tal ideologia leva, ao limite, a que se pergunte: há negros e índios no Brasil, ao menos no seu espaço civilizado? Por mais ingênua e cretina que esta pergunta seja, ela orientou durante muitos anos (durante os primeiros setenta anos do século XX) a política e cultura nacionais. (Guimarães, 2004)

Especialmente para o tema em debate, é forçoso reconhecer, pois, que o modelo de desenvolvimento hegemônico, gerador dos conflitos ambientais, se dá à margem e em detrimento dos grupos discriminados na história do Brasil. Portanto, não se pode perder de vista o processo de colonização europeia, que conjugava expansão mercantil, racismo e dominação étnica. Não porque se mantém intocado nas novas determinantes de expansão capitalista, mas porque se reinstitui na forma das grandes corporações nacionais e transnacionais, dos organismos multilaterais dominados pelos países do Norte que pressionam os territórios, suas populações e ecossistemas, e na forma de um estado de direito que, a despeito das conquistas populares e/ou dos chamados 'grupos específicos', tem origens na modernidade burguesa e dela guarda muitos de seus aspectos estruturantes. 


\section{Como bem analisa o indiano Baxi (2007),}

o EDD [estado democrático de direito] na metrópole foi durante muito tempo rubrica da dominação dos homens sobre as mulheres, dos donos dos meios de produção sobre os possuidores da força de trabalho, e da perseguição de minorias religiosas, culturais e civilizacionais (...). Até mesmo as histórias insurgentes que geraram um reconhecimento universal dos direitos humanos contemporâneos são reconhecidas erroneamente como uma imitação histórico-mundial do EDD euroamericano! O fato histórico que comunidades de resistência e povos em luta não ocidentais tenham enriquecido as concepções do EDD 'abrangente' é simplesmente encoberto pelos mitos persistentes das origens 'ocidentais'; a promoção do EDD como exportação cultural valiosa mantém a velha contaminação em formas ainda mais agressivas nessa era da globalização contemporânea.

No estado de direito brasileiro, os contraditórios e conturbados processos de conquistas e retrocessos no trato legal das questões indígena e quilombola são um exemplo perfeito da maneira como as necessidades e interesses desses povos são institucionalmente subordinados aos interesses do capital neocolonialista e suas dimensões étnicas e raciais.

O Estatuto do Índio, assinado por Garrastazu Médici em plena ditadura militar (1973), considerava os indígenas seres "relativamente capazes", a serem "tutelados" pelo Estado. Se isso foi modificado em sua essência na Constituição de 1988, que reconheceu sua identidade cultural, própria e diferenciada, assim como o "direito originário ao usufruto de suas terras", o novo Estatuto que regulamentaria esse direito está desde 1994 paralisado na Câmara Federal.

Em razão das demandas 'produtivistas' pelos territórios ancestrais, procura-se, por meio de projetos de lei diversos, rever as conquistas indígenas. Se a pressão da sociedade leva à retirada de uma Proposta de Emenda Constitucional já aprovada na Comissão de Constituição e Justiça e de Cidadania, em menos de 24 horas um Projeto de Lei Complementar ainda pior o substitui, como foi o caso da Proposta de Emenda Constitucional (PEC) 215/2000, trocada pelo Projeto de Lei Complementar (PLP) 227/2012. A PEC transforma a aprovação da demarcação das terras indígenas, a ratificação das demarcações já homologadas e o estabelecimento dos critérios e procedimentos a serem adotados nas diversas etapas em prerrogativa de um Congresso Nacional no qual os ruralistas somam 25\% dos parlamentares. O projeto vai bem mais longe ao propor alterações no próprio parágrafo $6^{\circ}$ do artigo 231 da Constituição Federal, onde estão definidos os direitos dos povos indígenas.

Se essa é a situação no Legislativo, no que concerne ao Executivo, a Convenção 169, aprovada pela Organização Internacional do Trabalho (OIT) 
em 1989 para regulamentar os Direitos dos Povos Indígenas e Tribais, só foi ratificada no Brasil em julho de 2002. Mais importante ainda é o fato de ela não ter sido até hoje regulamentada pelo governo, o que permite ao Estado desconsiderar, quando lhe apraz, as garantias por ela estabelecidas, como aconteceu com o artigo $6^{\circ}$, que trata do denominado direito à consulta livre, prévia e informada, e com o artigo $7^{\circ}$, que, com base no artigo anterior, trata do "direito de definir suas próprias prioridades" - direito de decidir.

Assim, ao contrário de outros países latino-americanos, como a Colômbia, onde a regulamentação da convenção promoveu até mesmo mudanças constitucionais (Botero, 2012), no Brasil prevalece o desrespeito à sua aplicação. Embora o próprio Ministério Público Federal mova ação após ação contra o governo, o processo de informação, consulta e aprovação (oitivas) dos povos indígenas não se deu no Xingu de Belo Monte, como ameaça não acontecer igualmente nos rios Tapajós e Teles Pires, apesar dos protestos e da resistência intransigente do Povo Munduruku. Convém lembrar que, ao ser ratificada, a Convenção 169 foi incorporada pelo sistema jurídico brasileiro, em posição hierárquica intermediária entre a Constituição e as leis ordinárias comuns (supralegal), de acordo com decisões do Supremo Tribunal Federal (STF). ${ }^{3}$

Não é difícil, pois, entender por que a antropóloga Lucia Helena Rangel, em seu artigo "Vulnerabilidade, racismo e genocídio", ${ }^{4}$ afirma:

Assassinatos, ameaças, morte de crianças, racismo, vulnerabilidade em saúde e nutrição, agressões ao meio ambiente, precariedades de toda sorte: são estes, entre outros, os fatores que compõem a violência e a violação de direitos que atingem boa parte da população indígena que vive em terras brasileiras, registrados em 2011. (Cimi, 2012: 12)

Em sua análise, Rangel cita mais de vinte povos indígenas que se encontram em situação de violação e violência institucional nas diferentes Regiões do país.

Da omissão da assistência à saúde, ausência de políticas de educação contextualizada, poluição socioambiental e destruição dos territórios ancestrais

\footnotetext{
${ }^{3}$ Conforme pareceres dos ministros relatores do STF, Sepúlveda Pertence (Ação Direta de Inconstitucionalidade - ADI - 1.675, julgada em 24/9/97 e publicada no Diário da Justiça de 19/9/2003), Celso de Mello (ADI 1.480, julgada em 4/9/1997 e publicada no Diário da Justiça em 18/5/2001); e Ricardo Lewandowski (Habeas Corpus HC-88.420, julgado em 17/4/2007 e publicado no Diário da Justiça em 8/6/2007).

${ }^{4}$ Publicado no relatório "Violência contra os povos indígenas no Brasil: 2011", do Conselho Indigenista Missionário (Cimi, 2012), esse documento é uma referência consistente para se compreender a situação atual dos povos indígenas e suas relações com os projetos de desenvolvimento e suas inter-relações com o Estado.
} 
ao assassinato. A realidade dos povos indígenas reflete, tal como afirma Cléber Buzzato (Cimi, 2012: 8), "nitidamente a existência de um pacto silencioso entre os poderes do Estado brasileiro em torno dos interesses do capital e de seus privilegiados beneficiários com o objetivo de desconstruir as bases do direito fundiário dos povos indígenas no Brasil".

Essa realidade, entretanto, não se restringe aos povos indígenas. Voltando à Convenção 169 da OIT, vale esclarecer um ponto que já suscitou questionamentos e justificativas totalmente infundadas: o significado da expressão 'tribais'. O texto da própria convenção torna o termo inequívoco já nos dois primeiros itens de seu artigo $1^{\circ}$.

1. A presente Convenção aplica-se a:

a. povos tribais em países independentes cujas condições sociais, culturais e econômicas os distingam de outros segmentos da comunidade nacional e cuja situação seja regida, total ou parcialmente, por seus próprios costumes ou tradições ou por uma legislação ou regulações especiais;

b. povos em países independentes considerados indígenas pelo fato de descenderem de populações que viviam no país ou região geográfica na qual o país estava inserido no momento da sua conquista ou colonização ou do estabelecimento de suas fronteiras atuais e que, independente de sua condição jurídica, mantêm algumas de suas próprias instituições sociais, econômicas, culturais e políticas ou todas elas.

2. A autoidentificação como indígena ou tribal deverá ser considerada um critério fundamental para a definição dos grupos aos quais se aplicam as disposições da presente Convenção. (OIT, 2011)

No caso brasileiro, portanto, a convenção, sem dúvida, se aplica igualmente às comunidades quilombolas e a todos os povos tradicionais, inclusive os 'nômades ou itinerantes', como os ciganos, por exemplo. A todos cabem o direito à consulta livre, prévia e informada e o direito à decisão, assim como as demais garantias que constam da Convenção 169. E também nesses casos eles são desrespeitados, como bem sabemos.

Às várias conquistas formais mencionadas aqui, poderíamos acrescentar o decreto 6.040 (Brasil, 2007), que institui a Política Nacional de Desenvolvimento Sustentável dos Povos e Comunidades Tradicionais; o Estatuto da Igualdade Racial (Brasil, 2010a); o Estatuto das Cidades (Brasil, 2001); e o Programa Nacional de Direitos Humanos, decreto-lei n. 7.177, reformulado em maio de 2010 (Brasil, 2010b). A despeito de refletirem avanços no reconhecimento das diversidades étnicas e raciais e das desigualdades históricas, tais conquistas não têm sido suficientes para garantir os direitos das populações aos territórios diante dos interesses desenvolvimentistas. 
Como se afirma no documento da Ceja/OEA (2004: 20), após listar diversas leis nacionais e tratados internacionais dos quais o Brasil é signatário, inclusive a Convenção Internacional para a Eliminação de todas as Formas de Discriminação Racial, "sin enbargo, la operatividad de estos instrumentos es mínima a nivel de jurisprudencia".

\section{Uma Leitura Antirracista sobre as Injustiças Ambientais no Brasil}

Considerando-se os conflitos e injustiças ambientais e seus impactos diferenciados sobre as populações desprivilegiadas, especialmente por suas características étnicas e raciais, propomos que, para o debate das questões socioambientais no Brasil, o racismo seja referido como ideologia e prática social baseada na hierarquização dos indivíduos e grupos sociais mediante sua racialização, que resulta em discriminação das raças consideradas inferiores. No processo histórico, especialmente de dominação dos povos pelos europeus desde o século $\mathrm{XV}$, os indivíduos e os grupos ditos de raça branca foram considerados e tratados como superiores. E os modelos de desenvolvimento geradores dos conflitos e das injustiças não se eximem desses processos históricos.

Compreender o problema étnico-racial nas injustiças ambientais nessa perspectiva não significa necessariamente entendê-lo como uma questão binária, pois se sabe que existem inúmeras variações e tensões no debate conceitual e, obviamente, nos sistemas de classificação racial, assim como na própria pluralidade dos contextos e das culturas, que impedem de afirmar de forma simplista que vivemos em um país de pretos e brancos. Tratase de considerar que, desde as teorias racistas, organizadas nos entremeios da abolição da escravatura até as modernas pesquisas e estatísticas que enquadram os quesitos cor e raça, as ideias, as práticas e os efeitos do racismo e do etnocentrismo não dizem respeito apenas aos 'múltiplos inferiorizados', mas também estão vinculados aos privilégios dos que assim não são considerados, abordando a 'branquitude' como problema.

Em outras palavras, trata-se de encarar o racismo como questão que afeta não somente as minorias, mas também quem, mesmo sem querer ou sem concordar com as premissas racistas, está situado em lugares de poder e goza de maior possibilidade de acesso ao mundo, ao poder político e à riqueza, seguindo o entendimento de Maria Aparecida Bento (2003). Ao analisar a 'racialidade' na produção do conhecimento e as dificuldades que enfrenta a produção intelectual antirracista, a autora afirma que 
quando pessoas brancas se voltam para o racismo, tendem a vê-lo como problema de negros e não como um problema que envolve a todos. Assim, brancos podem ver os trabalhos antirracistas como um ato de compaixão pelo outro, um projeto esporádico, externo, opcional, pouco ligado às suas próprias vidas, e não como um sistema que modela suas experiências diárias e seu sentido de identidade. (...) Tornou-se usual no Brasil justificar a situação das desigualdades raciais como um 'problema do negro', como se não fosse decorrente de uma relação entre negros e brancos, estando os brancos frequentemente ausentes dos levantamentos e análises que buscam explicar o fenômeno. (Bento, 2003)

Essa abordagem se deve também a uma compreensão ético-política de que, do mesmo modo que o enfrentamento da pobreza e das desigualdades de classes exige questionar a riqueza e sua distribuição, o enfrentamento do racismo implica questionar a branquitude e seus privilégios, debate que tem sido construído especialmente pela produção feminista, que articula os problemas das desigualdades considerando as imbricações entre as dimensões de classe, raça e gênero.

Por fim, a escolha dessa abordagem também é importante porque, embora possamos considerar as diversidades de populações atingidas ora identificadas pela raça, pela cor, pela etnia ora por modos de vida, as estruturas de poder dominante são majoritariamente brancas, quer no que se refere ao Estado, quer no que se refere às empresas e empresários, identifiquem-se ou não seus agentes como tais. Reconhecer a existência dos privilégios é ainda mais difícil quando, na tradição de pensamentos e práticas racistas, a população branca aparece como destituída de cor e raça (Piza, 2000). Ademais, mesmo o reconhecimento das diversidades de cores e culturas no Brasil não anula o fato de que,

chamado ou não de 'racismo', um crescente conjunto de dados testemunha o fato de que, no Brasil, tanto os 'pretos' quanto os 'pardos' (pessoas que parecem ter ascendência africana) estão em desvantagem considerável com relação aos brancos em termos de condições de saúde, mortalidade, educação, emprego, renda e riqueza. Os pretos e pardos também estão amplamente sub-representados entre aqueles que têm cargos públicos, nos níveis mais altos do meio empresarial, nas imagens da mídia e no establishment acadêmico do ensino superior. Eles constituem uma proporção exagerada, em relação à sua participação na população em geral, no conjunto dos pobres brasileiros. $\mathrm{E}$ as pesquisas de opinião pública também demonstram que a aparência africana é menos valorizada do que a estética europeia e constitui uma fonte de estigma em muitos contextos. (The Southern Education Foundation, 1999: 29)

Outros importantes elementos incidem na produção das injustiças ambientais e, decerto, nem todas essas injustiças estão atreladas automaticamente ao racismo. Porém, entendemos que, para bem debater as relações 
entre conflitos ambientais, raça e etnia, é importante considerar a incidência de outros fatores de discriminação frequentemente vinculados a tais injustiças, como a origem regional - que faz com que no Sul/Sudeste, principalmente (mas também no Centro-Oeste), nordestinos e nortistas sejam vistos e tratados como 'não brancos'-; modos de trabalho e relação com a natureza; bem como outras categorizações difusas, internas ou externas aos grupos.

Essa ampliação do leque de fatores de discriminação nos ajuda a atentar para mais duas questões sobre injustiças ambientais e suas interfaces com as discriminações étnico-raciais, de forma a lhes dar visibilidade e a incluí-las no debate que precisamos aprofundar ainda mais. A primeira diz respeito aos diversos grupos que, por seus traços físicos, culturais, políticos e econômicos, se diferenciam e/ou se distanciam do 'modelo ideal branco-ocidental-burguês' historicamente imposto e que, embora não se autoidentifiquem publicamente como povos indígenas, comunidades negras ou quilombolas, são considerados atrasados em relação ao modelo desenvolvimentista herdado da tradição branca. Isso acontece, por exemplo, em algumas comunidades que se autoidentificam como agricultoras familiares tradicionais (ou camponesas), ribeirinhas, pescadoras, quebradeiras, faxinalenses, geraizeiras, de fecho ou fundo de pasto, vazanteiras, extrativistas, entre outros povos tradicionais.

A segunda questão envolve as populações urbanas que não são identificadas como brancas em seus traços físicos e culturais, tampouco apresentam autoidentificação coletiva principal como negras ou índias, mas sobre elas recaem mais direta e imediatamente as injustiças ambientais nas cidades, como é o caso, por exemplo, dos moradores das periferias, do entorno dos aterros sanitários e das demais áreas de risco.

\section{As Origens do Racismo Ambiental como Conceito e como Elemento Articulador da Luta Política}

Antes de nos referirmos especificamente ao Mapa de Conflitos, cabe melhor contextualizar o tema 'racismo ambiental', a partir de suas origens, mostrando a forma como ele se transforma numa categoria importante para o debate e o enfrentamento das injustiças e conflitos ambientais. Os dados apresentados no mapa, vistos sob essa ótica, ajudarão a identificar e revelar o racismo ambiental no contexto brasileiro.

O reverendo Benjamim Chavis foi quem empregou pela primeira vez a expressão 'racismo ambiental', durante sua participação na luta em Warren County, nos Estados Unidos. Era início dos anos 1980, e a população negra dessa cidade da Carolina do Norte lutava desde o final da década anterior 
para que rejeitos tóxicos não fossem depositados naquele local, visto que, entre outros efeitos, tais rejeitos contaminavam o lençol freático superficial da região. Em 1982, a situação atingiu seu clímax quando os habitantes tentaram impedir com os próprios corpos a passagem dos caminhões. Mais de quinhentas pessoas foram presas durante o protesto que não conseguiu evitar que o carregamento fosse despejado. Porém, a população negra de Warren não perdeu completamente a batalha: o protesto tornou-se notícia, e o governador se comprometeu com o fechamento imediato e a limpeza do depósito (que só terminaria no início do século XXI). Mais importante ainda, um novo momento para a luta pelos direitos civis havia começado.

Chavis, que era formado em química e, portanto, conhecia os perigos da contaminação, afirmou:

Racismo ambiental é a discriminação racial nas políticas ambientais. É discriminação racial no cumprimento dos regulamentos e leis. É discriminação racial no escolher deliberadamente comunidades de cor para depositar rejeitos tóxicos e instalar indústrias poluidoras. É discriminação racial no sancionar oficialmente a presença de venenos e poluentes que ameaçam as vidas nas comunidades de cor. E discriminação racial é excluir as pessoas de cor, historicamente, dos principais grupos ambientalistas, dos comitês de decisão, das comissões e das instâncias regulamentadoras. (Chavis, 1993: 3)

O fato de a situação de Warren County ter conquistado, em 1982, o direito de chegar aos meios de comunicação levou a que outras denúncias fossem feitas, de estados variados, mas sempre com uma constatação que se repetia: 0 ônus de receber rejeitos contaminados e indústrias agressivamente poluentes cabia invariavelmente a bairros habitados pela população negra. E isso acontecia principalmente nos oito estados do sul, onde 3/4 dos depósitos de rejeitos estavam concentrados em bairros negros, embora eles representassem apenas $20 \%$ da população da região. ${ }^{5}$

A luta contra esse estado de coisas foi assumida pela Comissão pela Justiça Racial da Igreja Unida de Cristo (United Church of Christ Commission for Racial Justice), dirigida, na ocasião, por Chavis, ativista que ainda moço havia conquistado os jovens da Carolina do Norte para militarem sob a liderança de Luther King. ${ }^{6}$ Com base em um estudo que coordenou com

\footnotetext{
${ }^{5}$ Dados tornados públicos pela Agência de Proteção Ambiental (Environmental Protection Agency - EPA) em 1983, em um primeiro levantamento realizado logo após o episódio de Warren County ganhar as manchetes.

${ }^{6}$ Em fevereiro de 1971, Chavis (com 25 anos) e outros nove jovens companheiros, entre os quais uma moça, foram presos em Wilmington, Carolina do Norte, acusados de terem incendiado uma mercearia cujo proprietário era branco. O grupo ficou conhecido como "Os dez de Wilmington" e, em 1976,
} 
o apoio da Igreja, Chavis (1987) publicou Toxic Waste and Race in the United States of America, mostrando a amplitude da questão dos rejeitos tóxicos nas comunidades negras do país. ${ }^{7}$

Em outubro de 1991, a Comissão pela Justiça Racial promoveu a primeira Conferência Nacional das Lideranças Ambientalistas de Cor, em Washington, reunindo mais de 650 ativistas dos cinquenta estados americanos e, ainda, de Porto Rico, México, Havaí, Chile e das Ilhas Marshall. Ao longo dos três dias, os participantes ampliaram sua visão acerca da injustiça e do racismo ambiental, perceberam o que havia além do problema de contaminação química, e reconheceram que seus efeitos ultrapassavam os limites das comunidades negras e atingiam não só os povos indígenas, os nativos do Alasca e os fazendeiros mexicanos como também latinos em geral, asiáticos e outros discriminados, da cidade e do campo.

Ao final da conferência, os delegados firmaram um documento com o título "Princípios da justiça ambiental". São exatamente 17 itens, que englobam desde o direito à educação até o protesto contra o uso da energia nuclear, por exemplo. Encabeçando-os, um curto preâmbulo:

Nós, PESSOAS DE COR, reunidas nesta Primeira Cúpula Nacional de Lideranças Ambientalistas de Cor para iniciar a construção de um movimento nacional e internacional de todos os povos de cor para combater a degradação e proteger nossas terras e comunidades, restabelecendo assim nossa interdependência espiritual com a sacralidade da Mãe Terra; em respeito e celebração a cada uma de nossas culturas, linguagens e crenças sobre o mundo natural, e os nossos papéis em curar a nós mesmos/as; para assegurar a justiça ambiental; para promover alternativas econômicas que possam contribuir para o desenvolvimento de meios ambientalmente seguros de subsistência; e para garantir a liberdade política, econômica e cultural que foi nos negada ao longo de mais de 500 anos de colonização e opressão, resultando no envenenamento de nossas comunidades e da terra e no genocídio de nossos povos, afirma e adota estes Princípios de Justiça Ambiental: (seguem-se os 17 princípios). ${ }^{8}$

\footnotetext{
foram condenados a um total de 282 anos de prisão. A maior pena coube a Chavis, condenado a 34 anos. Considerados prisioneiros políticos, os jovens foram defendidos com protestos e campanhas, até mesmo da Anistia Internacional, enquanto erros eram sucessivamente apontados nos processos. Finalmente, três das testemunhas de acusação confessaram ter mentido sob juramento, pressionadas pelas autoridades locais. Os dez de Wilmington foram libertados após alguns anos de prisão, mas somente em 1980 uma investigação do Departamento de Justiça cancelou as condenações.

${ }^{7}$ Roberto Bullard (1990) publicou um segundo livro sobre o assunto enfocando a parte sul do país: Dumping in Dixie: race, class and environmental quality. No segundo capítulo do livro, "Race, class, and the politics of place", o caso de Warren County é detalhadamente narrado e analisado, mas Chavis tem seu nome apenas lembrado, em meio ao de outros religiosos e ativistas que participaram da luta.

${ }^{8}$ Disponível em: <www.justicaambiental.org.br/projetos/clientes/noar/noar/UserFiles/17/File/17_ principios.pdf $>$.
} 
Em 1993, Robert Bullard organiza um livro - Confronting Environmental Racism: voices from the grassroots - cujo prefácio foi escrito por Chavis. No curto texto, Chavis defende a importância do combate ao racismo e à injustiça ambiental, não só nos Estados Unidos, mas em todo o planeta. E explicita sua justa preocupação com relação ao Terceiro Mundo. Para o reverendo, a tendência seria de que, à medida que a luta nos Estados Unidos fosse bem sucedida, os países pobres se tornariam depositários das grandes cargas de rejeitos tóxicos oriundos de indústrias e de outras atividades poluentes como consequência da debilidade de sua legislação. Como sabemos, isso de fato aconteceu.

Bullard denuncia as intercessões e cruzamentos entre racismo e capitalismo (ou luta de classe, se preferirmos) nos problemas ambientais dos Estados Unidos, afirmando, por exemplo, que

as iniquidades ambientais não podem ser reduzidas somente à questão de classe ou à habilidade de algumas pessoas de migrar para escapar de meio ambientes poluídos. Raça e classe estão intrinsecamente ligadas na nossa sociedade. Todavia, a raça continua a ser um potente determinante de onde a pessoa mora, de qual comunidade é atingida, e qual é poupada. O preconceito racial cria e perpetua qualidades ambientais desiguais em comunidades de cor ou brancas. (Bullard, 1993: 11) ${ }^{9}$

Embora o termo racismo ambiental esteja no título do livro e no do capítulo que escreve - "Anatomy of environmental racism and the environmental justice movement"-, Bullard só utiliza a expressão nessas duas ocasiões. Entretanto, ao longo do texto o autor disseca seus efeitos, denunciando as injustiças ambientais contra negros principalmente, mas também contra povos indígenas, mexicanos e outros migrantes. Para o sociólogo, a grande importância da luta mantida pelos 'ativistas de base' estava no fato de ela própria reunir as reivindicações sociais e a questão ambiental. Assim, explicita a necessidade de esses ativistas influenciarem o 'grande ambientalismo', de forma a viabilizar a construção do conceito 'justiça ambiental', afirma que "o movimento ambientalista já mostrou que pode melhorar a qualidade de vida no país, mas não se envolve em conflitos ambientais que afetam comunidades de cor" (Bullard, 1993: 39, grifo nosso) e encerra:

Todavia, a cooperação entre as duas principais vertentes do movimento ambiental é tanto possível quanto benéfica. (...) Os ativistas de base têm sido os que mais influenciam a inserção dos problemas da equidade e da justiça social na agenda ambientalista maior e a democratização e a diversificação do movimento

\footnotetext{
${ }^{9}$ Os trechos originalmente em inglês deste capítulo tiveram tradução livre de Tania Pacheco.
} 
como um todo. Essas mudanças são necessárias se o movimento ambientalista de fato quiser ser bem-sucedido na disseminação de um movimento verdadeiramente global por uma sociedade justa, sustentável e saudável e efetivamente se resolver a encarar as disputas ambientais. Ativistas ambientalistas e pelos direitos civis de todos os matizes deveriam dar as boas-vindas ao movimento crescente dos afro-americanos, latinos, asiáticos, das ilhas do Pacífico e índios americanos, que estão dando força à luta pela justiça ambiental. (Bullard, 1993: 39)

É importante considerar - e as afirmações de Bullard indicam isto - que, na efervescência da construção do movimento pela justiça ambiental nos Estados Unidos, os participantes dos movimentos negros também lutavam, paralelamente, para que a questão racial ganhasse espaço dentro das lutas ambientalistas, até então predominantemente constituídas por brancos.

Martinez-Alier (2007) cita a luta dos movimentos das 'pessoas de cor' dos Estados Unidos em prol da participação nas instâncias diretivas do movimento ambientalista e suas organizações. Seus apontamentos indicam também a importância da luta racial 'declarada', própria do racismo segregacionista estadunidense, para evidenciar o racismo no interior das grandes organizações ambientalistas, assim como para movimentar nestas o debate das questões ambientais sob a ótica das desigualdades sociais e dos efeitos e causas raciais. Nesse contexto, as denúncias das 'lideranças de cor' deixavam bastante evidente que não era (e ainda não é) fortuito, mas intencional, o fato de o Estado e as empresas poluírem prioritariamente seus locais de moradia ou de negarem às populações 'não brancas' as políticas necessárias para uma qualidade de vida realmente digna.

\section{Racismo Ambiental: um conceito necessário para enfrentar as injustiças ambientais no Brasil}

Considerando, ainda que de forma rápida e sucinta, as experiências dos Estados Unidos e as análises de Chavis (1993), Bullard (1993) e MartinezAlier (2007), podemos estabelecer um paralelo com a realidade brasileira. Obviamente, há de se considerar importantes limites ao se comparar os dois países nos termos da situação racial e dos fatos e desdobramentos históricos experimentados. Dos processos de colonização, violência e segregação racial às diferentes formas de lutas e resistências antirracistas, muitas questões podem ser contraponteadas, relativizadas ou 'traduzidas', e uma das mais importantes é o fato de que, nos Estados Unidos, o racismo foi historicamente autodeclarado e juridicamente ordenado.

Aqui, o debate apresenta alguns aspectos complexos que não podem ser esquecidos ou reduzidos, entre os quais o fato de ser paradigmática a 
constituição sociocultural, política e econômica do colonialismo no Brasil, assim como a ideologia fortemente impregnada do mito da democracia racial. No caso das populações negras, por exemplo, diferentemente dos Estados Unidos e a despeito das conquistas do movimento negro,

no Brasil, ninguém aparece como racista declarado, e todos parecem reprovar o racismo e o racista. Todos se declaram simpatizantes, amigos ou parentes de pessoas negras, ou, até mesmo, assumem-se como pessoas negras, porém isso não parece impedir a exclusão cultural, política e econômica dos afrodescendentes. (Sales Jr., 2009: 29).

Se, nos Estados Unidos, as leis da segregação deixavam totalmente evidentes os espaços a serem ocupados por negros e brancos, no Brasil ocorreu tamanha invisibilização do racismo que, em muitos casos, este acaba por se manifestar, às vezes, de forma totalmente inconsciente por parte de quem o pratica. O relatório da Ceja/OEA cita uma sentença de um caso de racismo em São Paulo que ilustra tal invisibilização. Ao justificar a improcedência da denúncia, o juiz afirma:

[En Brasil] los de piel más oscura incluso son ídolos de los más claros en el deporte y en la música y las mujeres popularmente llamadas 'mulatas' parecieran sentirse orgullosas de ello y se exhiben con gran suceso en muchos locales de la moda y de la fama. En Brasil las personas 'blancas' se casan con personas 'negras' $y$ tienen hijos normalmente (...). Aquí no tenemos el racismo riguroso y cruel de otras naciones, donde los no 'blancos' son segregados, separados y no tienen los mismos derechos. Eso sí es racismo. (Ceja/OEA, 2004: 24)

Os afrodescendentes constituem apenas 13\% da população estadunidense, ao passo que os últimos dados do Instituto Brasileiro de Geografia e Estatística (IBGE) mostram que em 2010, pela primeira vez na história do Brasil, o total de autodeclarados negros (brancos mais pardos) superou o de autodeclarados brancos, atingindo 50,7\% da população, ao contrário dos revelados em 2000, quando 53,7\% se autodeclaravam brancos (IBGE, 2010). Jefferson Mariano, analista socioeconômico do IBGE, explicou à jornalista Débora Melo que essa inversão fazia parte de uma mudança cultural que tinha sido observada desde o censo de 1991: "Muitos que se autodeclaravam brancos agora se dizem pardos, e muitos que se classificavam como pardos agora se dizem pretos. Isso se deve a um processo de valorização da raça negra e ao aumento da autoestima dessa população" (Melo, 2012). Nesse processo de autorreconhecimento e de crescente autoestima, a luta contra o racismo tem lugar de destaque, mas está bem longe de ser resolvida. E, em contrapartida, o número de autodeclarados indígenas se manteria em $0,4 \%$ (818 mil pessoas, das quais $60,8 \%$ estavam concentradas em áreas rurais), segundo o instituto. 
O fato de constituírem uma minoria formalmente segregada e criminalizada ao longo dos séculos levou os negros norte-americanos de uma subserviência regulamentada por leis à organização e à rebelião do Movimento pelos Direitos Civis, duramente conquistados na década de 1960, principalmente. E a conscientização sobre a existência do racismo ambiental e a luta contra ele surgiram quase como uma resultante natural dessa organização e dessa rebelião. De certa forma, era a luta pelos direitos civis que continuava, agora com um novo elemento agregado: o ambiental.

No Brasil, entretanto, o esforço histórico das elites para o embranquecimento da nação, o mito da democracia racial e a miscigenação - que tem na violência sexual contra as mulheres 'de cor' um de seus marcos históricos invisibilizados ${ }^{10}$ - dificultam o reconhecimento do próprio racismo e o estabelecimento de políticas de desconstrução das desigualdades que desfavorecem a maioria da população 'não branca', sobretudo as mulheres.

As diferenças históricas entre Estados Unidos e Brasil, entretanto, não eximiram os dois países de apresentar consequências semelhantes. No relatório internacional "Além do racismo", os autores informam que:

A discriminação racial assumiu diferentes formas no Brasil, na África do Sul e nos Estados Unidos, mas com resultados extraordinariamente semelhantes. (...) Não apenas aqueles que sofreram a opressão racial foram privados de seus direitos políticos de participar nos processos democráticos de seus próprios países, como também foi abrangente a desvantagem emanada da discriminação racial. Sua natureza era política, social e econômica.

\section{(...)}

Em todos os três países, a maioria dos homens acreditava na subordinação de todas as mulheres. Estas eram excluídas do voto, de muitas espécies de trabalho remunerado e da maioria das posições de liderança. Julgava-se que a 'anatomia' ordenava o 'destino' das mulheres, fossem estas brancas ou negras. (The Southern Education Foundation, 1999: IV e 6)

No que se refere às injustiças ambientais, se nos Estados Unidos é principalmente nos territórios negros, latinos e asiáticos que se evidenciam os danos sociais e ambientais do desenvolvimento, no Brasil é nos bairros pobres das periferias urbanas (visivelmente de maioria negra) e nos territórios indígenas, quilombolas e das outras comunidades tradicionais que se instalam as indústrias químicas; o agronegócio dos agrotóxicos, do trabalho escravo e dos desertos verdes; as mineradoras e as siderurgias; as hidro e

\footnotetext{
${ }^{10}$ Estamos tratando de uma sociedade patriarcal, onde os homens - brancos ou negros, opressores ou revolucionários - tradicionalmente subordinam as mulheres e desconsideram seus interesses.
} 
termelétricas; e outras atividades produtivas cujos impactos ambientais sobre a vida, o trabalho, a cultura e a saúde estão marcados no Mapa de Conflitos. E são majoritariamente esses contingentes os expropriados, contaminados, despejados, remanejados, enfrentando direta e imediatamente as perdas e danos colaterais do desenvolvimento econômico.

A presença majoritária de negros, índios e 'não brancos' no lado 'prédesfavorecido' dos conflitos mostra que se aplicam ao Brasil todas as afirmações de Chavis (1993) sobre racismo ambiental: a discriminação racial nas políticas ambientais, no cumprimento dos regulamentos e das leis, na escolha deliberada das comunidades de cor para depositar rejeitos tóxicos e instalar indústrias poluidoras e no reconhecimento oficial da presença de venenos e poluentes que ameaçam as suas vidas.

Mais importante talvez seja o fato de que a definição de discriminação racial trazida por Chavis (1993) também se remete ao fato de serem exatamente esses contingentes populacionais que, no Brasil, sempre estiveram excluídos dos processos decisórios. E isso também se aplica às políticas e projetos que provocam os danos sociais e ambientais identificados no mapa. A ausência, deslegitimação, invisibilização e o não reconhecimento dos 'não brancos' nos espaços de decisão das políticas oficiais de qualquer natureza, assim como a imposição (pela força ou pelo convencimento) dessas políticas são elementos que definem os rumos do desenvolvimento econômico no país.

No que se refere aos conflitos explicitados pelo mapa, se fizermos uma distinção entre agressores e agredidos, nitidamente se verifica quem são os privilegiados em termos raciais. E, se podemos dizer que em alguns casos o preconceito e a discriminação racial estão explícitos nas falas, nos escritos e nas ações, como, por exemplo, na inferiorização dos índios e de suas culturas, na maioria das vezes ele é velado e só se mostra quando nos conscientizamos das tramas mais amplas que compõem o racismo nas estruturas da sociedade.

Além das origens sociais dos sujeitos antagônicos dos conflitos ambientais serem extremamente desiguais, a implementação dos projetos e políticas de desenvolvimento econômico acontece acompanhada de um processo naturalizado (às vezes sutil, porém sempre potente) de desqualificação, inferiorização e subordinação dos modos de vida locais e, consequentemente, da desvalorização e invisibilização das populações, sejam urbanas ou rurais. Ainda que tal implementação seja também acompanhada do discurso da melhoria da qualidade de vida, essa suposta melhoria está atrelada à aceitação subordinada dos interesses e modos de vida dos agressores. Observamos, com base em informações contidas no mapa, que o maior 
problema mencionado pelas populações no âmbito da saúde é exatamente a piora na qualidade de vida.

É possível que, na maioria dos casos, não possamos afirmar que as empresas ou políticas agridam determinadas comunidades, seu território e sua cultura de forma necessariamente intencional ("Vamos para aquela região porque eles são negros ou índios"). Contudo, é impossível negar que a precariedade do acesso às instituições públicas e as desigualdades políticas e econômicas tornam essas populações, a priori, desfavorecidas e prejudicadas pela sua histórica exclusão (ou inclusão subordinada, real ou potencial) das instâncias oficiais mais amplamente reconhecidas e legitimadas de exercício do poder. E isso, aliado às possibilidades do mercado, faz toda a diferença no momento de decidir por qual território optar. Nesses casos, não se pode negar que a condição inferiorizada dos habitantes constitui um fator que facilita a sobreposição dos interesses da iniciativa privada e do Estado desenvolvimentista.

Como 'herança atualizada' do colonialismo que marca a realidade brasileira, negros, índios e 'não brancos' de um modo geral não estão equitativamente representados nos processos decisórios; não participam do sistema jurídico; estão sub-representados no poder legislativo; seus modos próprios de fazer política e economia, assim como seus conhecimentos, saberes (explorados e expropriados) e necessidades têm status inferiorizado, exotizado e estigmatizado, incompatível com o 'progresso'. Nesse caso, progresso e desenvolvimento significam, sobretudo, o agravamento da subordinação desses grupos aos modelos sociais, políticos e econômicos que marcam tradicionalmente o ideário colonizador branco, burguês e ocidental, no qual o racismo é, ao mesmo tempo, parte histórica da ideologia e instrumento de dominação dos povos.

Nesse contexto, ressaltamos a importância do conceito 'racismo ambiental' para a organização política dos grupos atingidos e das lutas ambientalistas. $\mathrm{Na}$ medida em que se problematizam por esse viés as injustiças socioambientais, a compreensão de seu componente étnico-racial colabora na construção de identidades coletivas e lutas articuladas. Dessa forma, tal componente faz emergir na cena pública a história, os estigmas e os processos que concorrem indubitavelmente para o desfavorecimento dos atingidos nos conflitos, ao mesmo tempo que articula e mobiliza diferentes sujeitos para uma luta ambientalista que contenha em seu âmago a denúncia e o enfrentamento do racismo. Isso amplia e torna complexa a leitura e a ação, já que pressupõe a emergência desses grupos como sujeitos, com suas vozes e histórias, contadas agora com base em seus próprios olhares, experiências e concepções. 
Tratar das injustiças ambientais levando em conta o racismo é mais que 'dirigir-se' diretamente aos povos indígenas, comunidades tradicionais e quilombolas partindo de uma ideia de localidades isoladas e de especificidades 'minoritárias', ou da noção de assimilação subordinada - o que se poderia dizer das populações urbanas negra e indígena - aos poderes e instituições dominantes. Considerar o racismo na problemática das injustiças ambientais significa reconhecer a posição e a importância política desses sujeitos étnico-racial e culturalmente diversos e entender essa diversidade sem distorções alegóricas, mas como condição humana e, portanto, histórica.

Romper com os essencialismos que folclorizam os atingidos, assim como politizar sua existência e as históricas negações que sobre esses contingentes recaem é, pois, um bom e promissor caminho para o enfrentamento das injustiças ambientais, posto que em boa parte é por meio dessas negações racistas por excelência - que tais injustiças se constituem.

\section{O Mapa e os Responsáveis pelos Conflitos}

Explicitados as perspectivas e os contextos, propomos um exercício de cruzamento dos dados do Mapa de Conflitos com as estruturas racistas dos conflitos ambientais com base na identificação dos agressores e seus lugares de poder. A Tabela 1 permite algumas reflexões sobre as diferentes formas de manifestação do racismo ambiental nos mundos rural e urbano. Para isso, escolhemos, de um lado, quatro grupos dentre as populações atingidas, portadores de diferentes características identitárias: povos indígenas, quilombolas, pescadores artesanais e moradores de zonas de risco urbanas. Paralelamente, levantamos 'o que' (atividade, processo produtivo, ou, até, política pública) cada um desses grupos considera seus principais antagonistas no conflito.

Dentre os 'causadores' dos conflitos, destaca-se a significativa posição de liderança ocupada pelo item "atuação das entidades governamentais" nos quatro grupos de atingidos. Essa atuação nunca se dá de forma isolada, mas se faz acompanhar sempre da atividade ou do processo produtivo que viabilizou quer por omissão, quer por interesses os mais variados, que vão do equilíbrio da balança comercial, via produção de commodities para exportação, à corrupção cotidiana na cultura política brasileira. É o caso, por exemplo, dos territórios entregues à sanha da monocultura, uma das maiores causas dos conflitos envolvendo povos indígenas, quilombolas e camponeses tradicionais. 
Tabela 1 - Número de conflitos* por populações e seus principais causadores

\begin{tabular}{|l|c|c|c|c|c|}
\hline \multicolumn{1}{|c|}{$\begin{array}{c}\text { Populações } \\
\text { atingidas }\end{array}$} & $\begin{array}{l}\text { Povos } \\
\text { indígenas }\end{array}$ & Quilombolas & $\begin{array}{l}\text { Pescadores } \\
\text { artesanais }\end{array}$ & $\begin{array}{l}\text { Moradores } \\
\text { de locais } \\
\text { inóspitos }\end{array}$ & Total \\
\hline $\begin{array}{l}\text { Causadores } \\
\text { Atuação de entidades }\end{array}$ & 48 & 36 & 19 & 22 & 125 \\
\hline $\begin{array}{l}\text { governamentais } \\
\text { Monoculturas }\end{array}$ & 35 & 24 & 7 & 1 & 67 \\
\hline $\begin{array}{l}\text { Políticas públicas e } \\
\text { legislação ambiental }\end{array}$ & 18 & 12 & 9 & 12 & 51 \\
\hline $\begin{array}{l}\text { Mineração, garimpos e } \\
\text { siderurgia }\end{array}$ & 14 & 8 & 9 & 17 & 48 \\
\hline $\begin{array}{l}\text { Barragens e hidrelétricas } \\
\text { Madeireiras }\end{array}$ & 20 & 10 & 11 & 6 & 47 \\
\hline $\begin{array}{l}\text { Indústria química e do } \\
\text { petróleo }\end{array}$ & 25 & 6 & 2 & 1 & 34 \\
\hline Total & 162 & 97 & 61 & 77 & 39 \\
\hline
\end{tabular}

* Cada conflito pode ser causado por diversos tipos de processos produtivos simultaneamente.

Fonte: Elaborado pelos autores com base nos dados do Mapa de Conflitos Envolvendo Injustiça Ambiental e Saúde no Brasil.

Nas cidades, siderurgia e indústria química e petrolífera lideram, quase empatadas. Mas, no caso de "mineração, garimpos e siderurgia", se examinarmos mais detidamente o teor das denúncias, veremos que os 14 casos envolvendo povos indígenas dizem respeito à mineração e garimpo, ao passo que os 17 casos urbanos se referem à outra ponta do processo: a siderurgia. Os pescadores artesanais, por sua vez, apresentam uma questão nova: o que de fato os atinge não consta da planilha; as atividades pesqueiras industriais e a carcinicultura são responsáveis por 12 conflitos nos quais estão envolvidos, embora não se encontrem na realidade das demais comunidades.

As especificidades dos conflitos estão fortemente vinculadas à potencialidade econômica dos ecossistemas para a produção mercantil, numa equação determinante na escolha dos locais onde se instalarão os grandes projetos. O fator econômico não seria, então, o motor dos conflitos? Em relação ao movimento do capital e do Estado em direção aos territórios, podemos dizer que sim. Mas, sob a ótica do racismo ambiental, perceberíamos que, bem antes desse movimento, os povos que nesses locais vivem e os agentes do desenvolvimento que ali chegam não são desprovidos de raça, etnia e cor. Mais que isso, tanto povo quanto agentes estão inseridos numa sociedade modelada fortemente por tais quesitos. É, pois, com base nesses lugares sociais historicamente racializados que os habitantes locais e os agentes 
externos' vão estabelecer relações, seguramente com forte predominância ideológica, política e econômica destes. E será com base nessas desigualdades que se darão os desfechos das decisões, na maioria dos casos.

Infelizmente, nos estudos sobre os conflitos ambientais não se enfocam as características raciais das elites econômicas e políticas que movimentam o modelo de desenvolvimento hegemônico que pressiona os diferentes territórios. Mas as estruturas racistas que, comprovadamente, modelam as classes sociais, indicam que não são os grupos discriminados pelo racismo e pelo etnocentrismo que majoritamente estão em situação de poder e privilégio nas diferentes dimensões da vida. Não haveria razão para a composição das injustiças ambientais ser diferente, já que são centrais para o desenvolvimento capitalista, sua economia e política, assim como para seus modelos de apropriação de riqueza e poder. Ademais, o racismo no Brasil não pode ser tratado simplesmente como uma 'intencionalidade', mas, principalmente, como uma espécie de círculo vicioso, no qual raça e classe se imbricam e retroalimentam e, por isso, às vezes se confundem, dificultando até mesmo o enfrentamento das injustiças geradas por uma e pela outra.

Esse quadro nos impõe, entretanto, outra pergunta, que é também um desafio: quem detém esse capital com o qual se busca exercer poder sobre as vidas das comunidades?

Há diversas formas de responder. Se formos verificar a forma como os sujeitos dos quatro grupos veem o papel dos fazendeiros, por exemplo, em suas vidas, a resposta será objetiva: para povos indígenas, eles estão presentes como principais responsáveis em trinta conflitos; para os quilombolas, em 33; e os pescadores mencionam, como já assinalado, 12 casos, e sete desses casos envolvem um tipo específico de fazendeiro - o carcinicultor. Por sua vez, os moradores urbanos não têm como identificá-los porque não lidam com eles em seu universo. Mas se analisássemos a questão mais a fundo, provavelmente encontraríamos o latifúndio, a pecuária ou as monoculturas entre as causas que os levaram, ou a seus ascendentes, a deixar o campo para viver nas zonas de risco das cidades.

Quem são, entretanto, esses 'fazendeiros', já que os escolhemos para exemplo? Há casos em que são citados diversos nomes, todos totalmente desconhecidos. Mas, se enveredarmos pelo campo dos grandes proprietários, há personalidades do mundo político (a senadora Kátia Abreu, do DEM, e o ex-governador do Tocantins, Siqueira Campos, do Partido da Social Democracia Brasileira - PSDB -, cada um merecedor de uma menção), do televisivo (o apresentador Carlos Massa, o Ratinho, também nominado uma vez) e, 
principalmente, do empresarial. E se formos adiante, privilegiando a identificação das grandes empresas das monoculturas, temos a Fíbria liderando, envolvida em 11 conflitos, seguida pela Suzano Papel e Celulose, em seis, pela Veracel, em dois, e pela Stora Enzo, em um.

O mesmo exercício poderia ser feito em relação aos conflitos envolvendo mineração e siderurgia, teoricamente; mas isso não funcionaria. Simplificar as informações pode levar a conclusões demasiado parciais e, muitas vezes, insuficientes para descortinar a amplitude dos interesses de determinado grupo. Por quê? Ao analisar os dados, o que se verifica é o aparecimento do nome da mesma empresa em diferentes setores produtivos. Na medida em que as empresas diversificam seus interesses, suas ações se espraiam por campos, às vezes, totalmente diferentes daquele a que estava ligada a atividade que as originou.

A Votorantim, por exemplo, está presente em 17 conflitos. Mas todos os conflitos em que está envolvida revelam algumas de suas múltiplas 'personalidades', dedicadas a diferentes setores: da monocultura (começando como VCP - Votorantim Celulose e Papel, que comprou a Aracruz, que se tornou a Fíbria, e que é, juntamente com a Stora Enzo, uma das donas da Veracel, em Eunápolis, no estado da Bahia) à mineração e siderurgia, passando pela fabricação de cimento, pela metalurgia e pela produção de energia. De todos esses, apenas seu setor ligado à produção de sucos não está envolvido em nenhum conflito. Porém, isso não quer dizer que ele não exista, já que o mapa não abrange todos os conflitos, e trabalhamos aqui com dados que vão até 2010.

A mesma empresa também aparece na lista com sua 'personalidade CBA' (Companhia Brasileira de Alumínio), da qual é coproprietária, juntamente com a Companhia Níquel Tocantins. E, nessa qualidade, está envolvida em outros quatro conflitos. Como Grupo VBC (Votorantim, Bradesco e Camargo Correa - as duas últimas presentes também em outros quatro conflitos) reaparece em caso de expulsão de indígenas, quilombolas e ribeirinhos para a construção da Usina Hidrelétrica (UHE) de Serra da Mesa. Em qual 'setor produtivo' situar a Votorantim, então?

Com essa ressalva, podemos trabalhar de forma mais realista, buscando, da extensa relação dos principais causadores dos conflitos, os resultados mais significativos do ponto de vista numérico: a Vale (antiga Vale do Rio Doce) lidera com 19 conflitos. Em um primeiro raciocínio, julgaríamos serem todos ligados à mineração. Mas, novamente, como classificar sua participação no Consórcio Candonga, em que aparece ao lado da Alcan (atual Novelis), 
Suez, Odebrecht (presente em outros cinco conflitos), OAS, Queiroz Galvão (presente em mais três) e outras, expulsando pescadores, ribeirinhos e agricultores para construir uma hidrelétrica em Minas Gerais?

Como classificamos a Petrobras, com 18 conflitos, que vão da destruição de manguezais e de seus berçários à construção de gasodutos sobre terras indígenas, passando pelas ameaças e agressões a pescadores artesanais feitas por suas empresas terceirizadas? Ou o Grupo Eike Batista, com 15 conflitos, divididos entre EBX (cinco), MMX (três), LLX (três), MPX (dois), OSX e OGX (um cada)? Ou a Bunge, com oito conflitos, que vão da monocultura óbvia à mineração de fosfato?

Considerando o papel do Estado, cabe ainda citar o papel do Banco Nacional de Desenvolvimento Econômico e Social (BNDES) no financiamento de atividades geradoras dos conflitos ambientais: ao todo, o mapa evidencia 29 casos nos quais seu nome aparece. A esse respeito, é necessária uma observação especial: não está contabilizada, nesses 29 conflitos, a participação do BNDES em Belo Monte, uma vez que o aporte financeiro se deu depois do fechamento dos dados com os quais estamos trabalhando. Fatos como esse com certeza se repetirão à medida que formos estudar os novos conflitos acrescentados ao mapa. E isso sem considerarmos aqui os aportes de capital, como no caso do aumento de capital da Votorantim para a constituição da parceria com a Aracruz e a instalação da Fíbria.

O financiamento público e as outras participações do Estado na liderança das atividades que provocam os conflitos ambientais indicam também que ele reconhece e legitima os agentes que, no mapa, são apresentados como agressores e, mais que isso, os subvenciona, quando não atua diretamente com eles.

Além disso, as instituições públicas se tornam agentes diretos das opressões e da piora da qualidade de vida dos povos também no que se refere ao não cumprimento das leis e dos tratados internacionais. À Convenção 169 poderíamos acrescentar o chamado Princípio 10 da Declaração Final da Conferência das Nações Unidas sobre o Meio Ambiente e o Desenvolvimento, realizada no Rio de Janeiro em 1992 (Eco-92), o qual estabelece essencialmente que

O melhor modo de tratar as questões ambientais é com a participação de todos os cidadãos interessados, em vários níveis. No plano nacional, toda pessoa deverá ter acesso adequado à informação sobre o ambiente de que dispõem as autoridades públicas, incluída a informação sobre os materiais e as atividades que oferecem perigo a suas comunidades, assim como a oportunidade de participar dos processos de adoção de decisões. Os Estados deverão facilitar e fomentar a 
sensibilização e a participação do público, colocando a informação à disposição de todos. Deverá ser proporcionado acesso efetivo aos procedimentos judiciais e administrativos, entre os quais o ressarcimento de danos e recursos pertinentes. (ONU, 1992)

Embora menos conhecido, mas, em sua essência, repleto das ideias presentes nos artigos $6^{\circ}$ e $7^{\circ}$ da Convenção da OIT, tal princípio, ao garantir os direitos de informação, consulta e decisão aos que denomina "comunidades vulneráveis e marginalizadas" sobre os assuntos relacionados ao meio ambiente, é outro exemplo de diretriz descumprida ou, no mínimo, sua não observância reflete o descaso por parte do governo brasileiro com os tratados internacionais.

Impossível negar, nas diversas facetas dessa realidade, a presença do racismo ambiental. Quem são esses empresários e quem é esse Estado, em termos étnico-raciais? Se nos dispusermos a um rápido mas ousado exercício mental e colocarmos uma 'lente racial' sobre eles, sobre seus corpos, sua pele, seus ideais e suas histórias de vida, será impossível não ver o quanto ali está uma presença marcadamente branca. Não só no alto e no médio escalões do Estado, em suas três esferas, como também nos grupos detentores e gerentes do capital expansionista, o qual - para sermos realistas - financia boa parte dos políticos, seus partidos e suas campanhas políticas. Um círculo vicioso que também tem cor.

\section{O Mapa, os Conflitos e a Luta das Comunidades por Direitos}

Quando tratamos de racismo e das pessoas por ele atingidas, tendemos sempre a encará-las como vítimas. E não há como negar que o sejam. No entanto, como também se revela no mapa, os grupos e populações envolvidos nos conflitos ambientais não são apenas vítimas. Ao contrário, compõem um amplo campo de resistências, materializadas em organizações, movimentos e militantes populares de muitos matizes que, ao mesmo tempo que lutam contra as injustiças e o racismo ambiental, constituem-se em sujeitos fundamentais na defesa de seus territórios.

Não propomos aqui uma visão romântica acerca dos atingidos, mas sim uma expressão coerente e consequente da postura que determinou a realização do mapa, a começar pelo seu nome: Mapa de Conflitos Envolvendo Injustiça Ambiental e Saúde no Brasil. Para que um caso seja pesquisado e faça parte do mapa é necessário, antes de tudo, que ele configure um conflito claramente deflagrado. Isso implicou muitas vezes o abandono de denúncias cruéis envolvendo casos de injustiça ambiental que, por mais violenta que 
fosse, não provocara a reação da comunidade que ou não a entendera como tal ou, sob seu peso, se deixara vencer e desistir. Nessas situações, restava encaminhar a denúncia a quem de direito, sempre que possível, porém sem incluí-la no mapa.

No contexto desses conflitos, mesmo usando a palavra 'atingidos', mesmo mencionando injustiças e violências às vezes absurdas, a partir deste momento, trataremos de sujeitos da luta política que participam ativamente de importantes disputas com a finalidade de garantir direitos coletivos. E é com esse enfoque que veremos, em seguida, quem são eles.

O mesmo modelo de desenvolvimento que levou o Brasil a ocupar a posição de sétima economia do mundo empurra as comunidades urbanas pobres para periferias que ele próprio degradou, a ponto de nelas se tornar impossível uma vida saudável. Trata de forma semelhante os moradores das regiões não urbanizadas da zona costeira, do campo e das florestas. No primeiro caso, os expulsos são majoritariamente negros e/ou nordestinos; no segundo, a diversidade dos atingidos engloba povos indígenas, quilombolas e as comunidades tradicionais que sempre fizeram do mar, do rio, da terra ou da floresta seu local de vida, de trabalho, de construção de laços e de tradições.

O cenário onde os conflitos acontecem já é, aliás, bastante revelador. Comecemos pela zona rural, em que vivem, segundo o censo do IBGE (2010), $15,6 \%$ dos habitantes do país, contra $84,4 \%$ de moradores das cidades. Os resultados do mapa estão em aparente oposição a esses dados, entretanto. De acordo com o levantamento, $60,9 \%$ do total de conflitos mapeados estão na zona rural; 30,8\%, na urbana; e 8,4\% estão situados em áreas que de alguma forma misturam as duas realidades, como em Belo Monte, por exemplo.

Essa disparidade entre o total de habitantes e o total de conflitos não acontece por acaso. Em primeiro lugar, as terras exigidas pelos hidro e agronegócios são muitas vezes maiores que a maioria das pequenas cidades brasileiras, e foi em tais terras que as comunidades tradicionais e camponesas se assentaram historicamente. Assim como foi nelas que os povos indígenas e as populações quilombolas garantiram (e lutam para continuar a garantir) sua existência. Mas, no modelo de desenvolvimento atual, é preciso livrar o território de seus 'embaraços', para que, por exemplo, os desertos verdes que dizimam terras e águas (quando não também o ar) se instalem com as monoculturas. E o mesmo em relação à pecuária ou aos grandes investimentos eletrointensivos, devoradores de energia, de água e, resumindo, de território. 
Em segundo lugar - e o papel desempenhado pelo mapa nesse sentido é da maior importância -, é preciso considerar também a visibilidade. Nas cidades, quando uma comunidade é expulsa de seu local de moradia, mesmo que os grandes meios de comunicação sejam coniventes com essa prática, a denúncia tem maiores possibilidades de chegar às rádios comunitárias e à Internet. Blogs, redes sociais e vídeos elaborados por movimentos sociais frequentemente mostram a ação da polícia, os depoimentos dos moradores etc., de tal forma que, dependendo do alcance da propagação da notícia, as chances serão de que até mesmo a chamada 'grande mídia' acabe se sentindo obrigada a mencioná-la.

Sem nenhuma pretensão de hierarquizar ou comparar a gravidade das injustiças urbanas e rurais, que, a nosso ver, são equivalentes em importância, mas apresentam características diferentes, não podemos negar que, nas regiões dos desmatadores, dos grileiros, dos jagunços e pistoleiros, construir a visibilidade é bem mais difícil. Nessas circunstâncias, a impunidade tem sido uma marca denunciada pelos atingidos e pelos estudiosos do assunto. E quando polícia, prefeitos e até mesmo juízes se deixam usar para acobertar desde a invasão, a ameaça e até a morte, garantindo impunidade tanto a quem a executa quanto a seus mandantes, na maioria dos casos a sociedade sequer toma conhecimento das injustiças praticadas. Como acontece com os assassinados, tais injustiças serão enterradas - literal e simbolicamente - e invisibilizadas.

O Gráfico 1 apresenta informações sobre os grupos atingidos, ao mesmo tempo que identifica os campos de resistências. Para essa discussão será necessário retomarmos alguns dados do capítulo 1. Antes, entretanto, uma explicação: como já foi dito, há muitas comunidades que se autoidentificam como integrantes de mais de um grupo, como, por exemplo, quilombolas que atuam como vazanteiros; agricultores familiares sem-terra; ribeirinhos que sobrevivem também como pescadores artesanais e extrativistas. Isso faz com que os percentuais do gráfico, se somados, cheguem a mais de $100 \%$.

Como podemos ver no Gráfico 1, os povos indígenas estão presentes em $33,7 \%$ dos conflitos. Com esse número, observamos um aspecto ainda mais relevante se considerarmos que, segundo o IBGE (2010), existem no Brasil cerca de 818 mil índios (número contestado por muitos indigenistas, que o estimam em cerca de um milhão e duzentos mil), constituindo cerca de 0,4\% da população. Deles, a maior parte, em números absolutos, estaria no Amazonas-168 mil-e, em percentuais relativos, em Roraima, representando $11 \%$ da população do estado. Entretanto, ressaltamos a forma como os conflitos envolvendo povos indígenas se encontram espalhados no mapa 


\section{Gráfico 1 - Principais comunidades envolvidas nos conflitos (\%)}

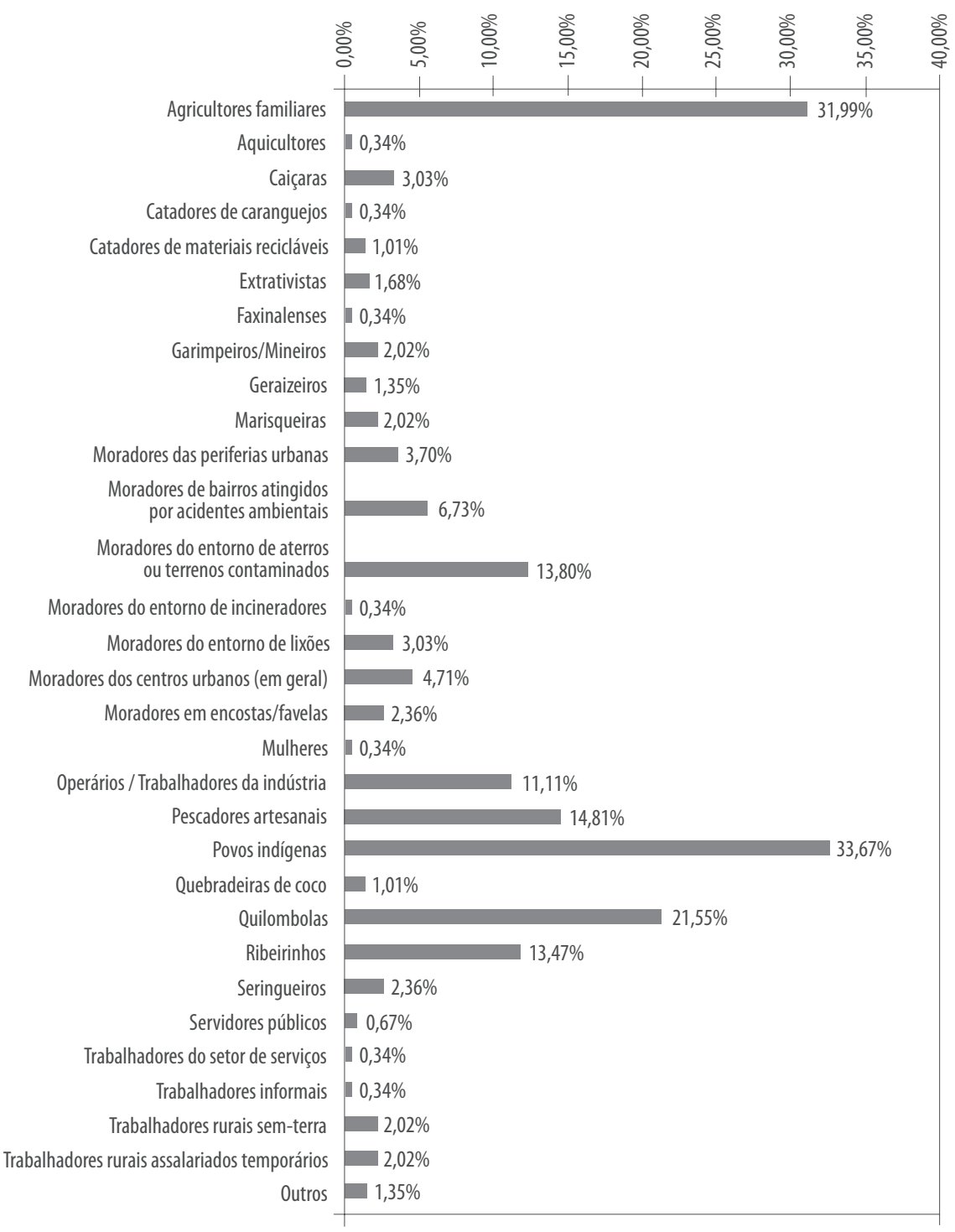

Obs.: Há muitas comunidades que se autoidentificam como pertencentes a mais de um grupo, como, por exemplo, quilombolas que atuam como vazanteiros; agricultores familiares sem-terra; ribeirinhos que sobrevivem também como pescadores artesanais e extrativistas. Da mesma forma, muitas vezes há mais de um dano ambiental, mais de um agravo à saúde e mais de um responsável pelo conflito. Essa sobreposição faz com que os percentuais dos gráficos, se somados, cheguem a mais de $100 \%$.

Fonte: Elaborado pelos autores com base nos dados do Mapa de Conflitos Envolvendo Injustiça Ambiental e Saúde no Brasil. 
para que tenhamos uma noção visual da sua amplitude, ainda que aqui restrita a um universo de apenas 297 casos.

Os casos se espalham por todo o Brasil, da zona costeira às fronteiras com outros países da América Latina, onde muitos povos, acolhidos por parentes, se refugiaram e hoje se encontram acuados. Em outros momentos, são os brasileiros que abrigam refugiados uma vez que os conflitos gerados por racismo ambiental não são 'privilégio' nosso (Figura 1).

Figura 1 - Distribuição dos conflitos envolvendo povos indígenas

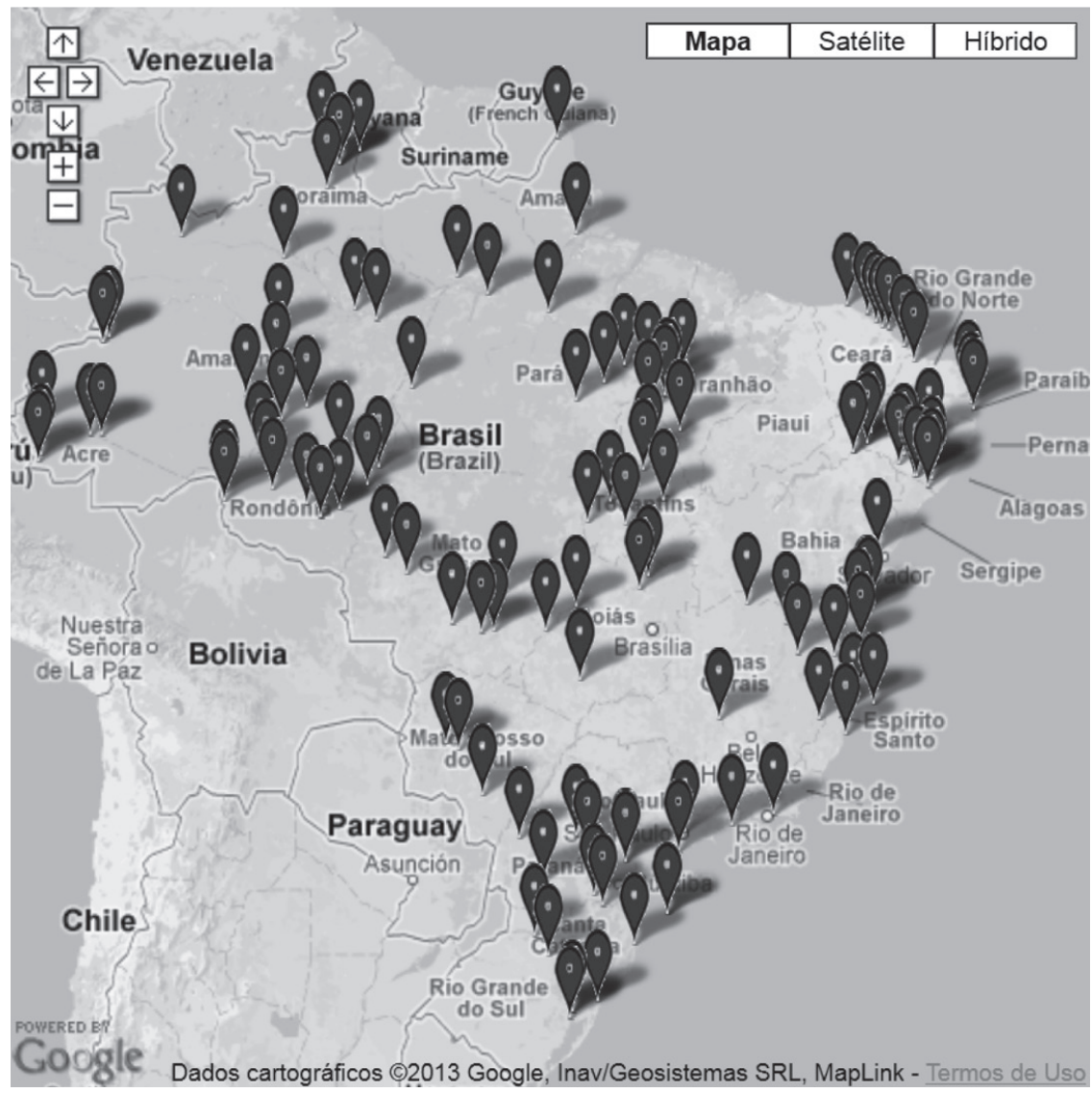

Fonte: Mapa de Conflitos Envolvendo Injustiça Ambiental e Saúde no Brasil.

Ao longo de décadas, as tentativas de mudanças nas leis e políticas indigenistas sempre são justificadas pelo fato de um número tão reduzido de indígenas não ter, afinal, necessidade de 'tanta terra'. Para defender, 
por exemplo, os Guarani-Kaiwá das balas dos jagunços, do genocídio e dos tratamentos subumanos a que têm sido submetidos às margens das estradas, que colaboram para garantir ao Mato Grosso do Sul o 'troféu' anual de assassinatos e suicídios indígenas, não teria sentido recorrermos ao argumento fácil de que, afinal, todo o Brasil pertencia a tais povos quando da chegada dos europeus. Preferimos, em vez disso, fazer uma breve comparação.

Para os povos indígenas, a terra não tem valor. Valor tem, sim, o território. Território é entendido como mata, lugar de plantar e de colher, lugar para a caça e para a festa, rios para fornecer os ingredientes dos cerimoniais, árvores para reverenciar ancestrais, floresta para acolher suas vidas e divindades. É necessário, assim, espaço para os animais crescerem e se multiplicarem; para as aves voarem livres e fornecerem as penas de seus cocares; para que a água corra límpida e não poluída, onde os peixes possam viver e proliferar. Para isso, há necessidade de território. Há necessidade de que as nascentes sejam protegidas, que os animais tenham supridas as necessidades de alimentos, até mesmo quando estes são outros animais.

É por isso que os Xavante, por exemplo, continuam a reivindicar a integralidade dos 165.241 hectares da sua terra indígena (TI) Marãiwatsédé, invadida na década de 1960 pela agropecuária Suiá-Missú e depois vendida à italiana Agip, que a devolveu ao povo indígena por ocasião da Eco-92. Nos seis anos entre a notícia da 'doação' e a sua homologação em 1998, o território foi novamente invadido e repartido, com anúncios em rádios e convocações das autoridades públicas municipais conclamando políticos, fazendeiros e até operadores do direito para dele se apossarem.

Para os que tomaram Marãiwatsédé, assim como para muitos de seus defensores, começando por seu advogado, irmão da senadora Kátia Abreu, trata-se de terra demais para apenas novecentos índios. Mas o que dizer do momento em que ela era ocupada pelos bois da Suiá-Missú e, posteriormente, da Agip? Ou hoje, arrasada também pela soja. Quantas pessoas de fato desfrutam dessa terra? Se 165 mil hectares é muito espaço para novecentos indígenas, o que pensar, tomando outro exemplo, dos 600 mil hectares de terra da União ocupados pela agropecuária Santa Bárbara, no Sul do Pará, e 'desfrutados', na realidade, por fundamentalmente um homem: Daniel Dantas?

Voltando ao mapa, aos povos indígenas, seguem os agricultores familiares, presentes em 32\% dos casos, e os quilombolas, ligados a 21,6\%. Entretanto, no total de agricultores familiares, estão também contidas diversas 
comunidades tradicionais, como os camponeses tradicionais, os geraizeiros, os faxinalenses, os vazanteiros e até muitos quilombolas. Embora sejam grupos que se autoidentificam inicialmente como agricultores, suas práticas, tradições e histórias deixam claro sua multiplicidade étnica e racial.

Há também os pescadores artesanais (14,8\%) e ribeirinhos (13,5\%). As demais comunidades tradicionais atingem, somadas, um total de $14,7 \%$, em que se incluem os aquicultores, caiçaras, faxinalenses, quebradeiras de coco babaçu, moradores de fundos ou fechos de pasto, catadores de caranguejos, geraizeiros, vazanteiros, marisqueiras, caiçaras, seringueiros e extrativistas em geral. Em todos esses exemplos, inclusive no dos agricultores familiares, tradicionais ou não, trata-se de gente que preserva o território e tem como parte importante de suas cosmovisões seus diversos elementos (terra, água, florestas etc.).

Nas áreas urbanas, a situação não é diferente. Se deixarmos de lado os operários (11,2\%) e examinarmos a lista dos diferentes tipos de 'moradores', o resultado não será surpreendente. Basta somarmos os das 'periferias' $(3,7 \%)$, de 'bairros normalmente atingidos por acidentes ambientais' (6,7\%), de 'aterros ou terrenos contaminados' (13,8\%), do 'entorno de incineradores' $(0,3 \%)$, do 'entorno de lixões' (3\%), de 'encostas ou favelas' (2,4\%), e, ainda, os 'de centros urbanos em geral' (os sem teto, com 4,7\%), e veremos que, mesmo nas áreas urbanas, 34,7\% dos casos também envolvem diretamente a questão do território ou do direito à moradia, se assim preferirmos falar. Isso acontece duplamente: grande parte dessas pessoas, cujo direito à cidade é negado, foi para ela expulsa, quer pela necessidade de buscar trabalho, quer pelas atividades produtivas de larga escala - muito mais comum nos dias atuais -, que se expandem pelos territórios rurais e costeiros onde vivia.

Assim, o racismo ambiental se explicita também - e muito fortemente nas cidades, onde a maioria absoluta dos atingidos nos conflitos são negros ou não brancos, incluindo-se, nesta última categoria, os casos em que os nordestinos e nortistas são os mais prejudicados, além de encarados de forma inequivocamente racista em muitas regiões. Não podemos esquecer, também, os índios urbanos, que, nos últimos anos, constituíram-se em uma categoria presente até mesmo no mapa. É a mesma discriminação, aliada à desigualdade, que empurra cada vez mais essas populações, num movimento incessante, ou para as encostas dos morros ou para os bairros periféricos, mais e mais longínquos e inóspitos. É nos lugares onde esses grupos vivem que verificamos as maiores ausências das políticas públicas e das condições necessárias para a vida. Além disso, o simples fato de residirem nesses locais já impõe uma série de restrições à participação digna e igualitária na 
realidade urbana. Não é à toa que, quando aparecem no mundo público, estão prioritariamente nas páginas policiais.

\section{O Mapa, o Racismo Ambiental e a Saúde das Populações}

No que se refere à saúde ambiental no Brasil, constatamos, especialmente desde a década de 1990, um importante avanço no arcabouço legal e nas formas institucionais de políticas. Desde a Constituição Federal e a implementação do Sistema Único de Saúde (SUS), em 1988, diferentes leis, decretos, instruções normativas e portarias versam sobre as intrínsecas relações entre saúde e meio ambiente. Esses aparatos formais incorporam a integralidade da saúde e a necessidade de se estabelecer na responsabilidade estatal a intersetorialidade necessária para garantir vida saudável às populações. Em seu documento de subsídio para a construção da Política Nacional de Saúde Ambiental, o Conselho Nacional de Saúde assim a define:

O campo da saúde ambiental compreende a área da saúde pública, afeita ao conhecimento científico e à formulação de políticas públicas e as correspondentes intervenções (ações) relacionadas à interação entre a saúde humana e os fatores do meio ambiente natural e antrópico que a determinam, condicionam e influenciam, com vista a melhorar a qualidade de vida do ser humano sob o ponto de vista da sustentabilidade. (Brasil, 2009)

Não obstante, mesmo considerando os princípios do SUS (universalidade, integralidade e equidade) e os avanços nas definições legais e institucionais sobre a saúde ambiental, a saúde é uma das áreas em que estão explícitas as marcas do racismo. Segundo informações da Criola, organização não governamental (ONG) voltada para a promoção dos direitos das mulheres, com sede no Rio de Janeiro, nos grupos considerados racialmente inferiores "é possível encontrar evidências de menor acesso a serviços de saúde, menor qualidade da assistência recebida, como por exemplo, menor acesso a especialistas e tecnologias de ponta, exames preventivos e a informações necessárias aos cuidados com a saúde" (apud Werneck, 2003).

A flagrante precarização do SUS e a privatização da saúde marcam uma apartação social e racial entre a população demandante. Como a maior usuária do SUS é a população negra, tal grupo sofre no seu cotidiano todos os efeitos advindos dessa precarização. Mas as adversidades enfrentadas pelas pessoas pobres, negras e indígenas (estes até pouco tempo 'agraciados' com os cuidados da Fundação Nacional de Saúde - Funasa) estão além das iniquidades do sistema de saúde. Constituem uma cadeia de vulnerabilidades em que os locais de moradia e trabalho são mais fortemente marcados 
pela ausência das condições para uma vida saudável, inclusive o acesso à alimentação, condição básica para a existência material.

As populações do campo são ainda mais prejudicadas, uma vez que, além da baixa qualidade nos serviços, enfrentam uma maior ausência de unidades de saúde e precisam percorrer longas distâncias para ter acesso a serviços médicos. Essa condição atinge, sobretudo, as mulheres, cultural e historicamente responsabilizadas pelos cuidados domésticos e pela saúde da família.

Considerando tudo isso, é necessário, antes de continuarmos a análise dos dados, retomarmos mais uma vez a concepção de saúde norteadora do trabalho do mapa. Essa visão de saúde

avança para além do bem-estar físico e mental, pois engloba, igualmente, o direito à terra, à cultura e às tradições, sem o qual chegamos, por exemplo, aos suicídios e infanticídios entre povos indígenas, incapazes de aceitar a perda de suas referências. Ou a casos como os dos quilombolas praticantes do Cabula no Espírito Santo, impossibilitados de manter seus rituais pela destruição da mata e, em consequência, desagregados e exilados de si próprios. Para uns como para outros, a falta de saída tornou-se responsável muitas vezes pela depressão, pela morte, pelo alcoolismo, pela prostituição. (Porto \& Pacheco, 2009: 15)

Nesse contexto, com o mapa, contribui-se também para indicar ações no campo da vigilância em saúde ambiental, em uma perspectiva ampla, participativa e intersetorial que vá ao encontro das demandas dessas populações, considerando não só a atenção básica à saúde, como os direitos humanos e culturais mais amplos. O que pode e deve ser 'traduzido' como uma ação que possa abarcar "o resgate da dignidade das comunidades atingidas, o enfrentamento da discriminação e do racismo, bem como recuperar a vitalidade dos ecossistemas dos quais os seres humanos como um todo dependem, em especial as populações tradicionais" (Porto \& Pacheco, 2009: 16).

Com esse entendimento, vejamos o que o mapa nos mostra em relação aos 'danos e riscos à saúde' causados pelos conflitos. Como já foi comentado no capítulo 1, entre esses agravos, a 'piora na qualidade de vida' lidera de forma absoluta, presente em 79,8\% dos casos, urbanos e rurais. Além disso, em relação à 'atuação das entidades governamentais', como responsáveis pela agressão às comunidades, essa 'piora' nunca aparece sozinha, acarretando outros problemas associados a ela.

Em relação à violência, problema tipicamente urbano, se somarmos as diversas formas como aparece no mapa - "ameaça" (37,7\%), "assassinatos" (10,1\%), "coação física" (15,8\%), "lesão corporal" (12,1\%) -, chegaremos a 
um total de 75,8\%, quase se equiparando ao agravo - mais geral - "piora na qualidade de vida". Se igualmente somarmos as questões das doenças não transmissíveis ou crônicas $(40,1 \%)$ às doenças transmissíveis $(18,2 \%)$, totalizaremos 58,3\%. Um número que se torna mais expressivo se comparado aos $30 \%$ de casos em que o agravo é a falta de atendimento médico.

A Tabela 2 apresenta algumas informações importantes. Mantivemos, como na Tabela 1, os mesmos quatro grupos de diferentes identidades povos indígenas, quilombolas, pescadores artesanais e moradores de zonas de risco urbanas - e levantamos, sempre com base nos dados contidos no mapa, a incidência dos seis tipos de danos à saúde mais presentes em relação a cada uma delas.

Tabela 2 - Relação entre populações e principais agravos/danos à saúde*

\begin{tabular}{|c|c|c|c|c|c|}
\hline $\begin{array}{l}\text { Populações } \\
\text { Agravos e } \\
\text { danos à saúde }\end{array}$ & $\begin{array}{l}\text { Povos } \\
\text { indígenas }\end{array}$ & Quilombolas & $\begin{array}{l}\text { Pescadores } \\
\text { artesanais }\end{array}$ & $\begin{array}{l}\text { Moradores } \\
\text { de locais } \\
\text { inóspitos }\end{array}$ & Total \\
\hline $\begin{array}{l}\text { Violências (ameaças, } \\
\text { assassinatos, coações } \\
\text { físicas e lesões corporais) }\end{array}$ & 48 & 41 & 14 & 5 & 108 \\
\hline $\begin{array}{l}\text { Doenças não } \\
\text { transmissíveis }\end{array}$ & 28 & 13 & 17 & 65 & 123 \\
\hline Insegurança alimentar & 32 & 31 & 16 & 5 & 84 \\
\hline $\begin{array}{l}\text { Falta de atendimento } \\
\text { médico }\end{array}$ & 32 & 31 & 0 & 10 & 73 \\
\hline Doenças transmissíveis & 31 & 6 & 3 & 13 & 53 \\
\hline Desnutrição & 18 & 6 & 3 & 2 & 29 \\
\hline Total & 189 & 128 & 53 & 100 & 470 \\
\hline
\end{tabular}

* Cada conflito pode estar associado a diversos tipos de agravos ou danos à saúde simultaneamente.

Fonte: Elaborado pelos autores com base nos dados do Mapa de Conflitos Envolvendo Injustiça Ambiental e Saúde no Brasil.

$\mathrm{O}$ agravo que mais oferece risco aos povos indígenas e quilombolas, com 48 e 41 casos, respectivamente, é a violência. Essa mesma violência, nas cidades, ao contrário do que seria de se esperar, aparece em apenas cinco casos dos pesquisados no mapa. Para entender melhor essa aparente contradição, é necessário considerarmos duas questões: primeiro, a violência à qual estamos nos referindo na Tabela 2; segundo, as populações urbanas nela mencionadas.

A desnutrição, a falta de atendimento médico e a insegurança alimentar também são formas de violência extremamente graves, assim como as 
doenças transmissíveis (e entre elas, as sexualmente transmissíveis têm destaque especial), que, em decorrência do 'progresso', cada vez mais acometem principalmente adolescentes majoritariamente do sexo feminino e mulheres.

Porém, não é sobre essas formas de violência que estamos falando no primeiro item da Tabela 2. Aqui, referimo-nos à violência típica das disputas territoriais no campo: ameaças, assassinatos, coações físicas, lesões corporais. Entre as populações representadas no mapa como protagonistas dos mais graves casos de injustiça e de racismo ambiental, as mais atingidas pela violência são as indígenas e quilombolas.

No caso dos moradores urbanos, entretanto, são as doenças não transmissíveis que lideram, com 65 casos. O que também é lamentável, mas facilmente explicável, se considerarmos que 38 desses 65 casos são de "moradores de aterros e/ou terrenos contaminados". E, nessa categoria específica, elas estão presentes em $100 \%$ dos conflitos. O tráfico, as milícias, a própria polícia também estão presentes nas vidas desses moradores urbanos, ameaçando e ceifando vidas. Mas, no universo específico dos 297 casos iniciais do mapa, os jagunços, os pistoleiros, os grileiros e os matadores de aluguel das áreas rurais é que são os agentes diretos da violência física que permeia os conflitos ambientais.

No caso dos povos indígenas, se somarmos os dois tipos de doença transmissíveis e não transmissíveis -, chegamos a 59 conflitos. E é também de tais povos que vêm as maiores queixas contra a falta de atendimento médico (32), a insegurança alimentar (também 32) e a desnutrição (18), comumente responsáveis pela morte de um grande número de crianças indígenas, anualmente.

Um parêntese relevante: ao buscarmos os dados de análise para este capítulo, se decidíssemos ignorar as percentagens e digitássemos a palavra 'Funasa' na seção de busca do mapa, encontraríamos 46 casos. E, se fôssemos verificar a que eles se referiam ou quais eram os grupos atingidos, a lista seria pequena: dois envolviam questões ligadas a contaminações químicas urbanas; oito diziam respeito a comunidades quilombolas; e 36 envolviam povos indígenas. A causa era sempre a mesma: atendimento à saúde precário ou inexistente, que geralmente levava à morte.

Todos os casos de suicídios que aparecem no mapa dizem respeito a indígenas que, expulsos de suas terras, alijados de suas tradições e culturas ou transformados em párias nas periferias das cidades, acabaram 'optando' pelo 'não ser' absoluto. Grande parte deles eram adolescentes. No relatório do 
Conselho Indigenista Missionário (Cimi) - "Violência contra os povos indígenas no Brasil" - (Cimi, 2010), registraram-se 19 casos de suicídio de indígenas ao longo do ano 2009. Esses casos, que não constam do nosso mapa, ocorreram todos em Mato Grosso do Sul, que também registrou 54\% de todos os assassinatos de indígenas em 2009. Apesar da revolta causada por esses dados quando de sua divulgação, em 2010 os números subiram para 57\% no estado - 34 casos do total de sessenta no país (Cimi, 2011). Em 2011, o número de assassinatos caiu para 51, em todo o Brasil, mas Mato Grosso do Sul aumentou sua participação na estatística: 32 casos, equivalentes a $62,7 \%$. E, dos 26 suicídios, 13 foram praticados pelos Kaiwá-Guarani do estado (Cimi, 2012).

No que se refere aos efeitos dos conflitos ambientais sobre a saúde das populações, poderíamos aumentar bastante a lista de diferentes agravos que recaem sobre elas se considerássemos o nível de tensão e estresse, especialmente entre os mais velhos e as lideranças que estão nas frentes de luta de defesa dos territórios. A ameaça direta ou a perda da terra, dos modos de vida e tradições, assim como outras ações de fundo claramente preconceituoso e racista são elementos que atingem diretamente a saúde dessas populações. São emblemáticos o já mencionado nível elevado de suicídio entre os povos indígenas e o agravo das doenças nervosas que, como aparente causa de morte natural, está fortemente vinculada às tensões vivenciadas pelas populações ameaçadas ou pelo alto nível de perdas que acompanham esses conflitos.

Do ponto de vista das políticas públicas, é notório o deslocamento e a desarticulação entre os diversos agentes. Se, de um lado, o Ministério da Saúde cria políticas de acordo com as necessidades e interesses das populações como a Secretaria Especial de Saúde Indígena (Sesai), voltada especificamente para esses povos, e a Política Nacional de Saúde Integral da População Negra -; de outro, é impotente diante do modelo de desenvolvimento predatório, injusto, racista, humana e ambientalmente insustentável. Um modelo que gera muito mais que os conflitos denunciados no mapa e que, como vimos, em grande parte acontecem com o apoio do próprio Estado.

\section{À Guisa de Conclusão}

O Mapa de Conflitos é, antes de tudo, uma ferramenta de usos múltiplos. Aliás, isso fica claro diante da pluralidade de análises que compõem este livro. Podemos afirmar que em todos os capítulos, mesmo partindo de diferentes olhares, desvela-se o que está em jogo em relação ao exercício do 
poder econômico, político e cultural. Fica evidente também a importante contribuição que o mapa oferece ao desenvolvimento dos processos políticos e organizativos voltados para a garantia dos direitos humanos e para a efetivação da democracia.

Especificamente para este capítulo, porém, buscamos no mapa as evidências da forma como os valores e práticas racistas dos indivíduos e das instituições que conduzem os rumos da sociedade, incidindo sobre os ciclos de discriminação na vida cotidiana e naturalizando-os, vêm comprometendo historicamente a democratização no Brasil.

Impossível fazê-lo sem mobilizar a reflexão crítica, a indignação e o posicionamento político de solidariedade, quer se trate dos Guarani-Kaiwá (Mato Grosso do Sul), dos quilombolas de São Francisco do Paraguaçu (Bahia), da comunidade do Cumbe (Ceará), dos assentados de Ipixuna (Pará), dos adolescentes negros assassinados nas periferias de nossas metrópoles e de tantos outros Brasil afora. O mapa tem também esta finalidade: mobilizar e desafiar as próprias comunidades, a academia, os ambientalistas, os operadores da justiça, os movimentos sociais, o Poder Executivo, as igrejas, as ONGs, os políticos que se preocupam com o bem-estar da população e do país, a indignarem-se e a agir.

Discutir as desigualdades e as discriminações étnicas e raciais deve ter, a nosso ver, o objetivo de entendê-las para enfrentá-las com o compromisso de construção da democracia. Além disso, enfrentar o racismo como problemática que incide sobre as questões ambientais implica um reconhecimento, pelos múltiplos sujeitos que buscam a justiça ambiental, não só da existência de vítimas do racismo ambiental, mas dos seus impactos sobre a própria composição dos sujeitos das lutas sociais. Isso equivale a reconhecer também que fatalmente as desigualdades raciais são marcas presentes no acesso ao conhecimento, à formação e à informação, assim como aos códigos sociais dominantes que condicionam o direito à vida digna e de qualidade.

Esse reconhecimento decerto pode gerar desconforto, especialmente se considerarmos a presença e até mesmo o incontestável ativismo de pessoas brancas na defesa dos direitos e na luta contra as injustiças ambientais. Não se pode compreender e enfrentar o racismo ambiental sem considerar aquilo que Sueli Carneiro tão bem nos ensina:

A branquitude, enquanto sistema de poder fundado no contrato racial, da qual todos os brancos são beneficiários, embora nem todos sejam signatários, pode ser descrita no Brasil por formulações complexas ou pelas evidências empíricas como no fato de que há absoluta prevalência da brancura em todas 
as instâncias de poder da sociedade: nos meios de comunicação, nas diretorias, gerências e chefias das empresas, nos Poderes Legislativo, Executivo e Judiciário, nas hierarquias eclesiásticas, no corpo docente das universidades públicas ou privadas etc. (Carneiro, 2005)

Nos Estados Unidos, foram os ativistas do movimento negro, oriundos dos embates pelos direitos civis, que construíram, a partir da luta popular, a conceituação de racismo ambiental e as formas de combatê-lo. Mais tarde, em 1991, foram ainda eles que criaram, da luta contra o racismo ambiental, o movimento por justiça ambiental. Pouco a pouco, os 17 princípios elaborados pelos delegados da Primeira Cúpula Nacional de Lideranças Ambientalistas de Cor adentraram a academia e as grandes organizações ambientalistas. No Brasil, entretanto, a história foi inversa.

Embora o conceito 'justiça ambiental' tenha chegado pelas portas da academia e com o apoio de ONGs e movimentos sociais, sabemos que até os dias atuais nem todos os ambientalistas - quer no campo governamental, quer no não governamental - foram conquistados para a luta contra as injustiças. O estabelecimento de unidades de proteção integral - como a da Jureia, mencionada no capítulo 1 -, sem levar em consideração a existência de povos e comunidades que lá nasceram e que há gerações protegem esses territórios, continua ocorrendo na nossa realidade.

Tendências marxistas ortodoxas costumam subestimar o debate sobre o racismo, que constitui a base material e imaterial do racismo ambiental. Tais tendências se limitam reconhecer-lhe, no máximo, uma importância 'acessória', entre outros vieses estruturantes das desigualdades que estão além (embora irrefutavelmente 'dentro') das lutas de classes. Quem sabe, concretizada a revolução, seria, então, o momento de encarar o racismo, institucional e ambiental? Ou, uma vez conquistada a hegemonia socialista, o racismo se desmancharia naturalmente no ar, com os demais efeitos deletérios do capital?

Enquanto não for entendido e plenamente aceito que o racismo é uma questão central (embora não a única) na construção da democracia, continuará a ser igualmente difícil aceitar a centralidade do combate ao racismo ambiental. E essa compreensão e as ações por ela provocadas são fundamentais para permitir que o enfrentamento das injustiças ambientais no Brasil aprofunde a radicalidade de seu caráter democrático. Esse é um dos principais desafios que, no Mapa de Conflitos, bem claramente se impõem. 


\section{Referências}

BAUMAN, Z. Modernidade e Holocausto. Rio de Janeiro: Zahar, 1993.

BAXI, U. O estado de direito na Índia. Revista Internacional de Direitos Humanos, 4(6): 6-27, 2007. (Edição em português: Rede Universitária de Direitos Humanos-SUR)

BENTO, M. A. S. Racialidade e produção de conhecimento. In: SEYFERTH, G. et al. (Orgs.). Racismo no Brasil. São Paulo: Peiropólis, Abong, 2003.

BOBBIO, N.; MATTEUCCI, N. \& PASQUINO, G. Dicionário de Política. Brasília: Editora UnB, 1986.

BOTERO, E. S. De como si es possible una política pública edificante para el reconocimiento a la diversidad étnica y cultural: el caso colombiano. In: CONGRESSO INTERNACIONAL DE DIREITOS DOS POVOS E COMUNIDADES TRADICIONAIS: AFIRMAÇÃO DE DIREITOS HUMANOS, I, 2012. Anais... Salvador: UFBA, 2012.

BRASIL. Estatuto das Cidades. Lei 10.257, de 10 de jul. 2001. Regulamenta os artigos 182 e 183 da Constituição Federal, estabelece diretrizes gerais da política urbana e dá outras providências. Disponível em: <www.planalto.gov.br/ccivil_03/leis/LEIS_2001/L10257.htm>. Acesso em: 15 jul. 2012.

BRASIL. Política Nacional de Desenvolvimento Sustentável dos Povos e Comunidades Tradicionais. Decreto 6.040, de 7 de fev. 2007. Institui a Política Nacional de Desenvolvimento Sustentável dos Povos e Comunidades Tradicionais. Disponível em: <www.planalto.gov.br/ ccivil_03/_ato2007-2010/2007/decreto/d6040.htm>. Acesso em: 15 jul. 2012.

BRASIL. Ministério da Saúde. Conselho Nacional de Saúde: subsídios para a construção da política nacional de saúde ambiental. Brasília: Ministério da Saúde, 2009.

BRASIL. Estatuto da Igualdade Racial. Lei 12.288, de 20 de julho de 2010a. Institui o Estatuto da Igualdade Racial, altera as leis números 7.716, de 5 de jan. 1989; 9.029, de 13 de abril de 1995; 7.347, de 24 de jul. de 1985; e 10.778, de 24 de novembro de 2003. Disponível em: <www.planalto. gov.br/ccivil_03/_Ato2007-2010/2010/Lei/L12288.htm>. Acesso em: 15 jul. 2012.

BRASIL. Secretaria Especial dos Direitos Humanos da Presidência da República. Programa Nacional de Direitos Humanos. Brasília: Secretaria Especial dos Direitos Humanos da Presidência da Republica, 2010b.

BULLARD, R. Dumping in Dixie: race, class, and environmental quality. Oxford: Westview Press, 1990.

BULLARD, R. Anatomy of environmental racism and environmental justice movement. In: BULLARD, R. (Ed.). Confronting Environmental Racism: voices from the grassroots. Cambridge: South End Press, 1993.

CARNEIRO, S. Em legítima defesa. Correio Braziliense, Brasília, 2005. Disponível em: <www. geledes.org.br/sueli-carneiro/em-legitima-defesa.html>. Acesso em: jun. 2011.

CENTRO DE ESTUDIOS DE JUSTICIA DE LAS AMÉRICAS (CEJA)/ORGANIZAÇÃO DOS ESTADOS AMERICANOS (OEA). Sistema judicial y racismo contra afrodescendientes. Santiago: Ceja, 2004.

CHAVIS, B. Toxic Waste and Race in the United States. Comission for Racial Justice, 1987. Disponível em: <www.ucc.org/about-us/archives/pdfs/toxwrace87.pdf>. Acesso em: 15 nov. 2012.

CHAVIS, B. Forward. In: BULLARD, R. (Ed.). Confronting Environmental Racism: voices from the grassroots. Cambridge: South End Press, 1993.

CONSELHO INDIGENISTA MISSIONÁRIO (CIMI). Violência contra povos indígenas no Brasil: relatório 2009. Brasília: Cimi, 2010. 
CONSELHO INDIGENISTA MISSIONÁRIO (CIMI). Violência contra povos indígenas no Brasil: dados de 2010. Brasília: Cimi, 2011.

CONSELHO INDIGENISTA MISSIONÁRIO (CIMI). Violência contra povos indígenas no Brasil: dados de 2011. Brasília: Cimi, 2012.

FAUSTINO, C. Combate ao racismo ambiental: uma luta justa por justiça ambiental, 2012. Disponível em: <www.racismoambiental.net.br/textos-e-artigos/cristiane-faustino/combate-aoracismo-ambiental-uma-luta-justa-por-justica-ambiental>. Acesso em: 15 jul. 2012.

GOMES, N. L. Alguns termos e conceitos presentes no debate sobre relações raciais no Brasil: uma breve discussão. In: BRASIL. Ministério da Educação. Educação Antirracista: caminhos abertos para a lei federal n. 10.639/03. Brasília: Secretaria de Educação Continuada, Alfabetização e Diversidade, Ministério da Educação, 2005.

GUIMARÃES, A. S. A. Preconceito de cor e racismo no Brasil. Revista de Antropologia, 47(1): 9-43, 2004.

INSTITUTO BRASILEIRO DE GEOGRAFIA E ESTATÍSTICA (IBGE). Censo Demográfico de 2010, 2010. Disponível em: <www.censo2010.ibge.gov.br/resultados/resumo>. Acesso em: 15 jul. 2012.

JACCOUD, L. Racismo e República: o debate sobre o branqueamento e a discriminação racial no Brasil. In: THEODORO, M. (Org.). As Políticas Públicas e a Desigualdade Racial no Brasil: 120 anos após a abolição. Brasília: Ipea, 2008.

MARTINEZ-ALIER, J. O Ecologismo dos Pobres. São Paulo: Contexto, 2007.

MELO, D. Em dez anos, população que se autodeclara negra aumenta, e número de brancos cai. UOL. São Paulo, 29 jun. 2012. Disponível em: <www.noticias.uol.com.br/cotidiano/ultimasnoticias/2012/06/29/em-dez-anos-populacao-que-se-autodeclara-negra-sobe-e-numero-debrancos-cai-diz-ibge.htm>. Acesso em: 3 jul. 2012.

MUNANGA, K. Uma abordagem conceitual das noções de raça, racismo, identidade e etnia. In:SEMINÁRIO NACIONAL RELAÇÕES RACIAIS E EDUCAÇÃO, 3, Niterói. Anais... Niterói: Penesb, 2003.

ORGANIZAÇÃO DAS NAÇÕES UNIDAS (ONU). Declaração do Rio sobre meio ambiente e desenvolvimento. Rio de Janeiro, 1992. Disponível em <www.ufpa.br/npadc/gpeea/DocsEA/ DeclaraRioMA.pdf>. Acesso em: 15 jul. 2013.

ORGANIZAÇÃO INTERNACIONAL DO TRABALHO (OIT). Convenção n. 169 sobre Povos Indígenas e Tribais e Resolução Referente à ação da OIT. 5. ed. Brasília: OIT, 2011.

PACHECO, T. Desigualdade, injustiça ambiental e racismo: uma luta que transcende a cor, 2007. Disponível em: <www.racismoambiental.net.br/textos-e-artigos/tania-pacheco/desigualdadeinjustica-ambiental-racismo>. Acesso em 15 jul. 2012.

PIZA, E. Branco no Brasil? Ninguém sabe, ninguém viu. In: HUNTLEY, L. \& GUIMARÃES, A. S. A. (Orgs.). Tirando a Máscara: ensaio sobre o racismo no Brasil. São Paulo: Paz e Terra, 2000.

PORTO, M. F. \& PACHECO, T. Conflitos e injustiça ambiental em saúde no Brasil. Tempus Actas em Saúde Coletiva, 4(4): 26-37, 2009.

PRINCÍPIOS da Justiça Ambiental. Disponível em: <www.justicaambiental.org.br/projetos/ clientes/noar/noar/UserFiles/17/File/17_principios.pdf>. Acesso em 15 jul. 2012.

SALES JUNIOR, R. L. O Mito da Democracia Racial e o Racismo Institucional no Fluxo da Justiça: raça e justiça. Recife: Fundação Joaquim Nobuco, Massangana, 2009.

SEYFERTH, G. O beneplácito da desigualdade: breve digressão sobre racismo. In: SEYFERTH, G. et al. Racismo no Brasil. São Paulo: Peiropólis, Abong, 2003. 
THE SOUTHERN EDUCATION FOUNDATION. Grupo Internacional de Trabalho e Consultoria. Além do racismo: abraçando um futuro interdependente - Brasil, África do Sul, Estados Unidos, 1999. Disponível em: <www.beyondracism.org/overview-portuguese.doc>. Acesso em: 15 jul. 2012.

WERNECK, J. (Org.). Desigualdade Racial em Números: coletânea de indicadores das desigualdades raciais e de gênero no Brasil. Rio de Janeiro: Criola, 2003. 2 v. 


\title{
3
}

\section{Povos Indígenas e Comunidades Tradicionais: os visados territórios dos invisíveis}

\author{
Jean Pierre Leroy
}

Jeovah Meireles

\section{Povos, Comunidades, Identidades}

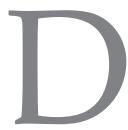

e um total de 297 casos de injustiça ambiental apresentados no Mapa de Conflitos Envolvendo Injustiça Ambiental e Saúde no Brasil (ou Mapa de Conflitos), ${ }^{1}$ recenseamos 202 que se referem a grupos sociais que poderiam ser chamados de povos ou comunidades tradicionais; verificamos injustiças que afetam mais de 72 povos indígenas, 44 comunidades quilombolas, 32 de ribeirinhos, 24 de pescadores artesanais e/ou marisqueiras, 28 de outros, em particular os seringueiros. Portanto, considerando que ainda há muitos casos a apurar, como mostram as denúncias que chegam continuamente à Rede Brasileira de Justiça Ambiental (RBJA), não trataremos aqui de casos isolados, mas de uma epidemia nacional.

O decreto n. 6.040, de 7 de fevereiro de 2007, que institui a Política Nacional de Desenvolvimento Sustentável dos Povos e Comunidades Tradicionais, no seu artigo $3^{\circ}$ define esses povos e comunidades como

grupos culturalmente diferenciados e que se reconhecem como tais, que possuem formas próprias de organização social, que ocupam e usam territórios e recursos naturais como condição para sua reprodução cultural, social, religiosa, ancestral e econômica, utilizando conhecimentos, inovações e práticas gerados e transmitidos pela tradição. (Brasil, 2007)

\footnotetext{
${ }^{1}$ Disponível em: <www.conflitoambiental.icict.fiocruz.br>.
} 
Como destacam Alfredo Wagner de Almeida e colaboradores, "a expressão 'comunidades', em sintonia com a ideia de 'povos tradicionais', deslocou o termo 'populações'”' (Almeida et al., 2010: 134). Poderia haver dúvida, em vários casos, se é pertinente ou não se qualificar como 'comunidade tradicional' um ou outro grupo atingido, mas essa dúvida não afetaria a seriedade das denúncias. Tal dúvida reflete ou a falta de informações precisas, ou a dificuldade de dar conta de realidades complexas e heterogêneas. Há ribeirinhos que se consideram agricultores familiares, cuja sobrevivência é ligada estritamente a atividades produtivas. Porém, - e isso parece bem mais frequente - há os que combinam produção com extrativismo. Pode ser que, no início do conflito, não se considerem comunidades tradicionais. Todavia, a injustiça ambiental que sofrem faz com que, mais cedo ou mais tarde, se reconheçam na definição e adotem essa identidade coletiva.

A esmagadora presença de casos envolvendo povos indígenas e quilombolas poderia fazer com que o leitor subestimasse a grande diversidade dessas comunidades apresentada pelo mapa. Ao se falar de comunidades tradicionais, evocam-se seringueiros, castanheiros, quebradeiras de babaçu, pescadores artesanais, marisqueiras, ribeirinhos, faxinalenses, geraizeiros, vazanteiros, povos dos fundos e fechos de pasto, caiçaras, entre outros. Os próprios povos indígenas e os quilombolas, conforme o ecossistema no qual vivem e as suas tradições, mantêm também relações diversificadas com o ambiente. A maioria dos termos que identificam essas comunidades se refere justamente ao laço que os identifica com seu ambiente, ressaltando, assim, a centralidade da noção de território, o que, nos casos do mapa, se evidencia.

O mesmo decreto n. 6.040 define territórios tradicionais como "os espaços necessários à reprodução cultural, social e econômica dos povos e comunidades tradicionais, sejam eles utilizados de forma permanente ou temporária" (Brasil, 2007). Essa definição seria insuficiente diante da densidade que a noção de território adquiriu ao longo da história desses grupos sociais, se, no decreto, não estivesse precedida da qualificação de povos e comunidades tradicionais. Território, para eles, é pleno de lutas, de cultura, de formas próprias de organização social e institucional e de economia, de memória.

A categoria 'conflito' é central nos casos de injustiça ambiental. Não há vítimas passivas. O Mapa de Conflitos é a expressão dos conflitos ambientais, conforme a definição de Acselrad (2004: 26):

Os conflitos ambientais são (...) aqueles envolvendo grupos sociais com modos diferenciados de apropriação, uso, e significação do território, tendo 
origem quando pelo menos um dos grupos tem a continuidade das formas de apropriação do meio que desenvolvem ameaçada por impactos indesejáveis transmitidos pelo solo, água, ar ou sistemas vivos - decorrentes do exercício das práticas de outros grupos.

Estamos em presença de duas concepções e duas formas de uso do espaço antagônicas; mais, de duas compreensões do que seria o desenvolvimento. Além dos 'impactos indesejáveis', em quase todos os casos está em jogo a continuidade da ocupação do território por comunidades e povos. Há, porém, casos de conflitos envolvendo povos indígenas e quilombolas relacionados à sua busca por reassentamento em terras das quais foram expulsos, mas que continuam vivas em sua memória.

Tornou-se senso comum a compreensão de que o desenvolvimento dominante, identificado como a busca permanente do crescimento baseado no uso intensivo dos recursos naturais, leva ao esgotamento desses recursos e à poluição irremediável do meio ambiente. Infelizmente, a opinião pública não vai além dessa constatação e não percebe que o espaço perde, então, as suas características ecossistêmicas - diversidade, complementaridade, resiliência, renovação - e se torna um espaço indefinido, mero suporte para as atividades econômicas e as infraestruturais. Assim, estão em risco a fertilidade dos solos, as águas, a diversidade biológica e genética, o clima e, com isso, a segurança alimentar e nutricional. A única estratégia para o capital parece ser a corrida tecnológica e uma crescente artificialização do planeta e da vida humana.

As comunidades e povos tradicionais estão na contramão desse desenvolvimento. Suas relações extrativistas e de usufruto estão estruturadas e inseridas nas teleconexões continente-oceano-atmosfera-hidrosferabiosfera, que fundamentam ancestralidades e vínculos interdependentes com a conservação dos biomas e ecossistemas. Os danos provocados por mercantilização e consumo dos recursos ambientais, base do conflito com o agro e hidronegócio, degradação dos bosques ribeirinhos e dos manguezais são evidenciados no mapa como indutores de injustiças ambientais, riscos à saúde coletiva e insegurança alimentar. Os empreendimentos relatados construção de ferrovias e vias de acesso, termelétricas a carvão mineral, polos petroquímicos e refinarias sobre sistemas ambientais de subsistência ancestral e cultural e locais de moradia - têm causado danos à qualidade e disponibilidade da água, do ar e do solo e a fragmentação dos territórios tradicionais e indígenas. Além disso, são acompanhados de tentativas de invisibilizar os atingidos, apresentando notadamente os valores mercantilistas de 'emprego e renda' como alicerces para o desenvolvimento. 
A espacialização dos conflitos evidencia as conectividades regionais e a lógica de consumo e financeirização da biodiversidade e diversidade de paisagens entre os principais sistemas ambientais - principalmente o Cerrado (grande divisor das bacias hidrográficas do Brasil), Caatinga, Amazônia e Zona Costeira - pelas monoculturas da soja, eucalipto e canade-açúcar, agropecuária extensiva, hidrelétricas, mineração e carcinicultura. Os deslocamentos forçados dos grupos sociais e indígenas são relatados como consequência de colapsos provocados pela exaustão dos recursos de vida cultural e subsistência. Tais colapsos são comumente relacionados à contaminação da água pelos agrotóxicos, perda da qualidade do solo com o incremento de processos erosivos que alcançam territórios de resistência e diminuição da biodiversidade pelo desmatamento da mata ciliar e dos bosques de manguezal.

Esses referenciais de conflitos - monopolização dos recursos ambientais à exaustão - são demonstrados como base da resistência e garantia de seus territórios e da manutenção das atividades econômicas relacionadas a estes, assim como da exigência de políticas voltadas para a gestão das águas, dos solos, da biodiversidade e das infraestruturas no campo e cidades. É possível constatar no mapa as consequências ambientais - em relação à qualidade de vida e ao usufruto por parte dos atingidos - e sociais, ocasionadas pela substituição dos sistemas ambientais por práticas relacionadas ao consumo e à privatização de extensos territórios.

As externalidades socioambientais negativas denunciadas são claramente vinculadas à apropriação capitalista dos territórios por grandes corporações empresariais e materializadas por meio dos inúmeros exemplos que demonstram a 'contínua destruição da natureza':

A introdução, em tais áreas, de monoculturas e pastagens, projetos viários, barragens, atividades mineradoras, etc. provoca grandes efeitos de desestabilização das atividades nas terras tradicionalmente ocupadas. Trata-se, portanto, dos casos em que, em certas combinações de atividades, o meio ambiente transmite impactos indesejáveis (as ditas 'externalidades') que podem fazer com que o desenvolvimento de uma atividade comprometa a possibilidade de outras atividades se manterem. Nesses casos, espaços produtivos privados transmitem os efeitos nocivos de suas práticas para o meio ambiente comum. (Acselrad, Campello \& Bezerra, 2009: 74)

Tais externalidades, entendidas como resultantes da conjunção de diversos danos ambientais aos ecossistemas responsáveis pela produtividade primária de uma complexa cadeia alimentar, demonstram que o mapa poderá também ser analisado na perspectiva da conservação dos sistemas ambientais, 
interligados por estratégias para amenizar as consequências, previstas, do aquecimento global e da injustiça climática. Nele, são espacializados os nexos entre as formas de apropriação dos territórios pelos mais diversos povos e comunidades tradicionais e indígenas e a qualidade e permanência das funções indissociáveis dos ecossistemas ligadas à amenização das consequências do aquecimento global.

Esses territórios estão repletos de reservas estratégicas de água doce nos aquíferos, nascentes e lagos, práticas e tecnologias ancestrais de conservação do solo e da biodiversidade e florestas inseridas nas reservas extrativistas que auxiliam na captura do dióxido de carbono emitido pelos combustíveis fósseis.

As formas de apropriação das comunidades tradicionais e indígenas constituem um conjunto de relações potencializadas pelas formas ancestrais de apropriação comunitária dos sistemas ambientais com seus 'códigos', informações e 'encantados' materializados no extrativismo, na produção de remédios, moradia, produção de alimento nas florestas, matas, roçados, fundos de pastos, vazantes, integrados aos saberes populares conectados aos rios, lagoas e o mar.

Ao ressaltar os cuidados desses povos e comunidades com o meio ambiente, não estamos atribuindo-lhes o mero papel de guardiões dos ecossistemas. Isso não corresponderia nem aos conflitos que enfrentam, raramente decorrentes desse papel, nem à maneira como eles próprios se veem. Assinalamos anteriormente como a sua identificação é ligada ao meio em que vivem (seringueiros, quebradeiras de babaçu, marisqueiras...), e essa identidade se refere às suas atividades econômicas. Território apresenta múltiplos sentidos, dentre os quais está o 'espaço de produção e de reprodução', a que nos referimos.

Os casos registrados no mapa não se referem a mendigos ou miseráveis inúteis, ou a sobreviventes do passado. Eles mostram povos e comunidades que asseguram a sua subsistência ou lutam para voltar a garanti-la e que têm projetos em relação ao futuro. Entretanto, o fato de cuidarem do meio ambiente e de assegurarem a sobrevivência de centenas de milhares de famílias não tem valor para o processo de desenvolvimento em curso. A RBJA, no ato da sua criação, formulou a seguinte definição de injustiça ambiental:

Entendemos por injustiça ambiental o mecanismo pelo qual sociedades desiguais, do ponto de vista econômico e social, destinam a maior carga dos danos ambientais do desenvolvimento às populações de baixa renda, aos grupos raciais discriminados, aos povos étnicos tradicionais, aos bairros operários, às 
populações marginalizadas e vulneráveis. (apud Acselrad, Herculano \& Pádua, 2004: 14, grifo do original)

\section{'Atraso' versus 'Desenvolvimento'}

Os povos indígenas e as comunidades tradicionais têm sido atingidos porque estão no caminho do desenvolvimento. Poderíamos observar que outros setores sociais também são impactados. No entanto, a etnicidade ou cor de tais povos e comunidades influenciam decisivamente na gravidade dos impactos que sofrem. Eles têm sido vítimas das seguintes atividades, em ordem decrescente do número de casos: agropecuária e grilagem, hidroelétricas, madeireiras, plantações de eucalipto, mineração, construção ou pavimentação de estradas, carcinicultura, siderurgia, produção de álcool/açúcar, turismo, hidrovias, barragens de irrigação, estradas de ferro, prospecção de petróleo, minerodutos, gasodutos, portos, pesca predatória, transposição do rio São Francisco.

As atividades agropecuárias, frequentemente associadas à grilagem e, no caso das áreas de floresta, às madeireiras, apresentam um número elevado de casos, atingindo principalmente os quilombolas em todas as regiões e povos indígenas do Nordeste, mas também da Amazônia, como se pode constatar em Rondônia, onde territórios indígenas têm sido alvo de invasão maciça. Tais atividades manifestam a continuidade do processo histórico de ocupação do espaço interiorano, em detrimento dos povos indígenas, das populações camponesas e de descendentes de escravos, e a continuação de práticas como a grilagem, manipulações cartoriais, violência, uso do poder público (executivos, legislativos, justiça, polícia), sedução. Em alguns casos de plantação de soja e algodão, de pecuária e nos casos de 'reflorestamento' e de plantação de cana, listados aqui por representarem um número significativo de conflitos, o confronto aparece diretamente com o agronegócio moderno, sem que isso signifique maior civilidade.

Outras atividades econômicas ligadas ao ciclo atual de desenvolvimento, em particular a mineração, aparecem em destaque. Porém, a soma dos empreendimentos de infraestruturas mostra a forma como, nos últimos anos, o Plano de Aceleração do Crescimento (PAC) e outros investimentos se estenderam pelo território brasileiro em áreas até então desprezadas pelo poder econômico. E isso se deu à custa de grupos populacionais que, justamente, encontraram sua sobrevivência nessas áreas porque estas não interessavam ao capital. É o caso do Cerrado e do sul da Amazônia, invadidos pelas plantações de eucaliptos, cultura de grãos e pecuária; dos rios, pelas 
hidroelétricas; do litoral, pelos portos, pela carcinicultura, pelos resorts; de montanhas de Minas, do Pantanal e da Floresta Amazônica, pela mineração.

Frequentemente, não é só uma atividade que impacta as comunidades, mas um conjunto delas, como acontece, por exemplo, com os Apinagé, no Tocantins, cujo território tem sido pressionado por diversos empreendimentos: hidroelétricas de Estreito e de Serra Quebrada, hidrovia Araguaia-Tocantins, estrada de ferro Norte-Sul, estrada de ferro Carajás, e, no seu o entorno, a soja.

$\mathrm{Na}$ fase atual de crescimento, redesenha-se a geografia da economia dominante. Somente para observadores atentos ela deixa transparecer, em filigranas, um pouco da injustiça ambiental. O Mapa de Conflitos inverte a perspectiva, ao priorizar a ótica das pessoas, finalidade proclamada do desenvolvimento, mas escamoteada pelo poder.

O Mapa de Conflitos representa um instrumento de poder das comunidades diante das ações das corporações transnacionais da energia (hidroelétricas, termelétricas), indústrias poluidoras, monoculturas, mineração, turismo de massa, entre outras. Essas corporações constroem seus próprios 'mapas' como instrumentos de reestruturação da 'modernidade' econômica, frequentemente incorporados pelo Estado para apregoar e operacionalizar políticas públicas.

Dessa forma, o Mapa de Conflitos é uma ferramenta eficaz para revelar os danos socioambientais, injustiça ambiental e ações concretas de racismo ambiental, e ao mesmo tempo para instrumentalizar as exigências propostas pelas comunidades e povos tradicionais para o cumprimento dos princípios da equidade, da precaução, da garantia ao livre acesso à terra e da ampla participação comunitária em todas as fases do licenciamento ambiental.

Apresenta à sociedade - principalmente às instituições de governo, movimentos sociais, universidades e demais organizações da sociedade civilum banco de dados que proporciona correlações e acompanhamento de tendências dos investimentos financeiros públicos e privados vinculados ao licenciamento ambiental para implantação e operação de empreendimentos que vêm degradando o modo de vida comunitário e os sistemas ambientais em territórios antes invisibilizados.

Evidencia que as ações mitigadoras foram predominantemente assistencialistas, prescritivas e se relacionavam com a internalização dos conflitos em processos estruturados que tinham como alvo a invisibilidade dos danos sociais e ambientais. A descrição de cada um dos conflitos revela que as relações de permanência e continuidade das atividades tradicionais, quer seja nas terras das comunidades tradicionais quer dos povos indígenas (TIs), 
configuram também territórios a serem continuamente permeados pelos direitos à terra, saúde e soberania alimentar.

O Mapa de Conflitos revela casos associados às estratégias das grandes empresas para se inserirem na 'economia verde' por meio de certificadores nacionais e internacionais, atestando "boas práticas de desenvolvimento sustentáveis" com o objetivo de garantir as exigências do mercado consumidor.

As comunidades tradicionais e indígenas do litoral nordestino denunciaram a emissão dos 'selos verdes' que categorizaram a produção de camarão e de outras monoculturas derivadas do agronegócio como 'orgânica' e como um produto com 'garantia de origem'. Demonstraram que essas atividades foram derivadas de processos de desmatamento da mata ciliar e do manguezal e da contaminação, fragmentação e extinção dos ecossistemas relacionados, regionalmente, aos biomas nacionais e, localmente, às bacias hidrográficas, agrossistemas e agricultura familiar.

Os conflitos registrados e decorrentes do desmatamento dos topos de morro e nascentes; da mineração e agronegócio com a contaminação da água, do solo e das pessoas; e da degradação do manguezal pela carcinicultura nos baixos e médios cursos fluviais evidenciam impactos cumulativos nas bacias hidrográficas. Aparecem espacializados no mapa e, quando relacionados aos territórios dos povos indígenas e comunidades tradicionais, revelam que os problemas enfrentados pelos atingidos são resultado dos mecanismos do mercado que controlam as economias regionais e transnacionais.

O contínuo processo de consumo dos recursos ambientais demonstra que os conflitos se instalaram em territórios-ecossistemas de amplo domínio dos povos e comunidades tradicionais e indígenas, resguardados e conservados, em sua integridade, para potencializar a qualidade de vida, suas práticas culturais e econômicas solidárias e a biodiversidade.

As principais questões enfrentadas pelos atingidos referem-se, como já dissemos, ao território, a começar pelo território físico:

No primeiro capítulo da sua obra sobre o significado da Territorialidade, o geógrafo norte-americano Robert Sack (1986) analisa a ocupação do espaço americano e sua configuração em território. Nessa passagem de espaço para território, a ocupação anterior dos povos ameríndios é ocultada. A qualificação do espaço como território transforma-o em espaço 'esvaziável', susceptível, pois, de ser preenchido conforme as necessidades de quem detém o poder sobre esse novo território. Limpeza conceitual e real das terras e traçados abstratos e geométricos de reivindicação de posse combinam-se para afirmar a territorialidade. (Leroy, 2010: 217) 
De modo similar, processa-se a ocupação do espaço brasileiro em detrimento de populações ignoradas, negadas, espoliadas e reprimidas. À diferença do Velho Oeste estadunidense, povos e comunidades tradicionais brasileiros, amparados pela constituição e pelos tratados internacionais assinados pelo Brasil, resistem à limpeza conceitual e real que os ameaça. Daí as lutas que enfrentam com mais frequência: a maioria dos quilombolas, pela sua titulação; numerosos povos indígenas, pela demarcação das suas terras, por seu reassentamento em suas terras originais, pela redefinição das TIs, pela consolidação da demarcação, contra a invasão das TIs; comunidades extrativistas, pela manutenção das reservas extrativistas e contra a invasão das suas terras. Não são somente lutas de resistência à desterritorialização, mas lutas de afirmação. Segundo Henri Acselrad (2010: 13), nesses processos, "o conceito de territorialidade tem se colocado como um elemento central na construção política da identidade dos sujeitos".

A invasão dos seus territórios se dá também indiretamente por meio dos impactos causados a eles e às pessoas pelos empreendimentos. Denunciamse a contaminação provocada por agrotóxicos, pela mineração, pela indústria química, por derramamento de óleo, pela poluição e as modificações na piscosidade dos rios provocadas por barragens. Mais do que isso, os casos mostram com frequência uma profunda desestruturação das comunidades, ocasionada por violência, compra e cooptação de pessoas, confinamento em áreas restritas, pressão da vizinhança, que as levam a situações de alcoolismo, consumo de drogas, prostituição, divisões internas. O exemplo mais dramático é o dos Kaiowá-Guarani, no Mato Grosso do Sul.

Geralmente, suas demandas por território e por justiça ambiental são antigas, mas passaram a ser exigidas com mais vigor no contexto democrático expressado pela Constituição de 1988, que tornou possível o Estado e parte da sociedade reconhecerem a histórica espoliação sofrida por esses povos e comunidades. No entanto, os casos mostram que, a partir de 2000, se iniciou um período de regressão, visível principalmente nas agroestratégias que visam a "remover os obstáculos jurídico-formais à expansão do cultivo de grãos" da agropecuária (Almeida, 2010a: 9), configurando uma "campanha de desterritorialização" (Almeida, 2010b: 385) com a cumplicidade e mesmo a participação ativa do Estado e do poder público, que vivenciam uma profunda contradição. Os governos simultaneamente impulsionam o desenvolvimento, provocador de grandes impactos socioambientais, e dão destaque aos direitos humanos, à saúde básica e à erradicação da miséria. Com o crescimento, ajudam famílias a sair da miséria e da situação de extrema pobreza, mas auxiliam outras a mergulhar nesse mesmo estado de carência absoluta. 
A Fundação Cultural Palmares (FCP) e a Secretaria de Promoção de Políticas de Igualdade Racial (Seppir) estão ao lado dos quilombolas, mas sem nenhum poder real para resolver a sua questão central: o domínio do seu território. O Instituto Nacional de Colonização e Reforma Agrária (Incra) mostra-se favorável às reivindicações, mas ora por falta de meios, ora por falta de poder, a sua efetividade de decisão e execução de titulagem de terras fica muito aquém das demandas. Por sua vez, a impotência da Fundação Nacional do Índio (Funai) é manifesta. Em algumas situações, algum órgão do poder estadual ou municipal aparece ao lado dos atingidos, mas há mais chance de encontrá-lo do lado dos agressores. Nesse quadro sombrio, sobressaem aliados quase indefectíveis dos povos indígenas e das comunidades tradicionais: o Ministério Público Estadual e, sobretudo, o Ministério Público Federal. Esses órgãos conseguem, às vezes, fazer com que o Poder Judiciário reconheça os direitos de comunidades e, quando não o fazem, com a sua presença ajudam-nas a se sentirem sujeitos de direitos e a não desistirem nas lutas pelo reconhecimento de tais direitos.

Quanto ao Poder Judiciário, suas decisões parecem ser tomadas com muito mais frequência com base nas leis que defendem a propriedade do que nas que garantem os direitos humanos. Destacamos aqui dois exemplos, dentre tantos outros. Parte das terras da Comunidade Quilombola de Pontinha atualmente está em posse de fazendeiros e da empresa VallourecMannesmann (V\&M). Da ficha do conflito do município Paraopeba, em Minas Gerais, consta: “Em 5 de dezembro de 2008, durante uma audiência judicial no Fórum de Paraopeba, o juiz (...) teria declarado que 'os quilombolas não deixam o país se desenvolver porque ficam segurando terra'". A seguir, tomamos ciência de que "o juiz deu ganho de causa a certo José Ribeiro da Veiga, sobre uma área de 9 hectares, sobreposta à área do 'comum da Pontinha', também chamada de 'larga', até então usufruída por todas as pessoas da comunidade". Esse senhor "teria recebido esses 9 hectares como pagamento por serviços prestados ao grande proprietário Pedro Moreira Barbosa, durante litígio com a comunidade". Em janeiro de 2009, em típica ação desenvolvimentista, "José Ribeiro da Veiga começou o desmatamento da área, com a licença do Instituto Estadual de Florestas (IEF) e sob a proteção de dez homens da Polícia Militar do Estado de Minas Gerais". Somente uma grande mobilização conseguiu sustar a ação.

O principal líder dos quilombolas do Boqueirão, em São Francisco do Paraguaçu, município Cachoeira, na Bahia, o sr. Altino da Cruz, morreu no dia 18 de dezembro de 2008, 
aos 60 anos de idade, enquanto trabalhava na sua roça. Ele não resistiu à notícia de que o juiz Fábio Rogério França, da $11^{a}$ vara da justiça federal, concedeu uma liminar de reintegração de posse solicitada pela fazendeira (...), exigindo que este [Altino da Cruz] se retirasse da roça que cultiva[va] há mais de quarenta anos e [que fora] herdada de seus pais (...). Segundo a cronologia da Associação de Advogados de Trabalhadores Rurais (AATR), a fazendeira teria usado de má-fé para levar o juiz a concluir que trata[va]-se de uma ocupação recente, quando é notório pela comunidade e pelos dados apresentados nos autos que trata[va]-se de uma comunidade tradicional.

Dois meses depois, a sra. Maria, outra grande líder da comunidade e amiga do sr. Altino, não resistiu à perda do companheiro e também faleceu.

Os Executivos federal e estaduais raramente manifestam oposição frontal aos atingidos. Isso não acontece com os municípios, visto que há numerosos casos em que prefeituras e vereadores encabeçam a oposição às reivindicações das comunidades. Defendem-se o progresso e o desenvolvimento, mas, em nome disso, o poder político local parece entrar em conluio com os agressores, quando não são as mesmas pessoas que detêm tanto o poder econômico quanto o poder político.

\section{As Comunidades e o PAC}

A sobreposição do Mapa de Conflitos ao mapa do projeto desenvolvimentista governamental é tão nítida que não pode se elidir a responsabilidade pública. Indiretamente, os governos passam a mensagem de que o desenvolvimento, produtor de riqueza e salvador da miséria, é a prioridade e não pode ser barrado. É como se eles dessem carta branca aos excessos. Mas a sua implicação é mais direta tanto nas obras que ministérios ou empresas estatais controlam quanto naquelas em que têm participação, em que se verifica o pouco interesse em resolver as questões sociais e ambientais e em rever seus procedimentos.

O Banco Nacional de Desenvolvimento Econômico e Social (BNDES) é pouco citado nos casos, mas questionamos as condicionantes que o banco impõe ao financiar empreendimentos. Os licenciamentos ambientais mencionados são realizados sem a participação dos atingidos e geralmente em detrimento deles; as condicionantes e os Termos de Ajuste de Conduta (TAC) não são cumpridos ou são insatisfatórios. Essas observações são públicas e notórias nos casos de grandes obras, tais como as hidroelétricas dos rios Madeira e do Xingu, mas chamamos a atenção para o caso de Minas Gerais, não tão conhecido. 
Tomamos o exemplo das pequenas centrais hidrelétricas $(\mathrm{PCH})$ Candonga, no rio Piranga, da Alcan e da Vale. São mencionados o desaparecimento de um morador local e ameaças de morte contra líderes dos atingidos; nas negociações com a população, cooptação de pessoas que se destacaram oferecendo-lhes vantagens; processo contra militantes do Movimento dos Atingidos por Barragens, acusando-os de causar esbulhos, para impedir manifestações pacíficas contra a barragem; polícia civil trabalhando em favor do consórcio, identificando e fotografando as lideranças sociais; a conivência de autoridades públicas, que não exigiram a implementação das medidas de compensação dos danos causados e não protegeram os direitos da população. As pendências sociais e ambientais foram postergadas em todas as fases do licenciamento ambiental e perduraram por quatro anos após a hidrelétrica ter entrado em operação. O que propiciou esse descalabro? Na ficha do caso, lê-se:

em 2004, o consórcio obteve do Conselho Estadual de Política Ambiental (Copam) a licença de operação (LO) da barragem, mesmo com o reconhecimento público de omissões e deficiências graves no tratamento com a população. Em agosto de 2008, o Copam revalidou a licença de operação de Candonga, mesmo reconhecendo as condicionantes não cumpridas desde a primeira concessão da LO em 2004, entre as quais, o Plano de Assistência Social e o Plano de Reativação Econômica para a população atingida.

É possível perguntarmos se os conselhos não se tornaram simples câmaras de aprovação dos empreendimentos, em um jogo de faz de conta, com a participação até mesmo de entidades ambientalistas e sindicais. Porém, tais entidades, às vezes cooptadas pelo 'mercado verde', outras vezes bem intencionadas, acabam dando a sua chancela às exações. Os mecanismos pretensamente criados para levar em conta as reivindicações da população não funcionam, ou, melhor, funcionam com uma finalidade oculta: defender outros interesses.

Não é de se admirar que, nessas condições, impere a violência. Tolerase, até por leniência do aparato judiciário, que o monopólio da violência, prerrogativa do Estado moderno, seja compartilhado com o setor privado, quando não transferido a ele. Dá-se, assim, continuidade ao Estado patrimonialista e coronelista. A lista das exações policiais impressiona, é tão grande quanto a da ação dos jagunços, capangas e milícias, e ambas as forças atuam não raras vezes em comum acordo. Todo tipo de crime é praticado: assassinatos frequentes e impunes, ameaças e agressões, destruição do patrimônio, ações do poder público e prisões ilegais, despejos.

À primeira vista, a violência é mais frequente em relação a comunidades que questionam o pretenso domínio dos fazendeiros tradicionais sobre terras 
que elas têm historicamente como suas, como se estivesse sobrevivendo o Brasil agrário do passado. Na realidade, há uma continuidade e uma renovação no exercício da violência. No Mato Grosso do Sul, onde se pratica uma agropecuária moderna, exerce-se uma violência extrema contra os povos indígenas. A mesma violência atribuída a estados situados na fronteira agrícola na Região Norte se faz presente, por exemplo, em Minas Gerais, não somente em razão das atividades agropecuárias tradicionais, mas também em virtude da mineração, das plantações de árvores e das hidroelétricas.

Além da violência direta, exercida sobre os corpos e as mentes, pode-se constatar que está presente a violência simbólica. Bourdieu (1972: 13) definiu o poder de violência simbólica como "qualquer poder que consiga impor significados e a impô-los como legítimos quando esconde as relações de força que são o fundamento da sua força" (tradução nossa). É como Diogo Rocha, redator da ficha do caso dos quilombolas de São Francisco do Paraguaçu (BA), exemplifica: "Numa clara inversão de papéis, as populações tradicionais são apresentadas como os verdadeiros causadores dos distúrbios à ordem e ao direito de propriedade, sendo-lhes imputado não apenas o caráter de impostores, como o de destruidores da natureza".

Decisões de justiça bem como informações vinculadas por grandes meios de comunicação funcionam como legitimadores da violência; legitimação que forma a opinião da sociedade local, mas também a dos próprios atingidos. Por isso, é necessário um enorme esforço da parte deles para reagirem e reconhecerem essa condição. Podemos imaginar quantos casos de injustiça e de violência não aparecem justamente porque as suas vítimas interiorizam tanto a sua condição de desigual que não imaginam que têm o direito de reagir.

A questão da saúde oferece mais um exemplo de violência simbólica. Em quase todas as fichas, se menciona "piora na qualidade de vida" ao lado de "violência" na seção "danos e/ou riscos à saúde". Por trás dessas categorias, ao ler os casos, é possível vislumbrar o enorme estresse psicológico e somático que sofrem as pessoas, as famílias e as comunidades em decorrência da violência. Estresse esse que está naturalizado porque "pobre é para sofrer mesmo".

No que diz respeito à saúde, no meio de tantas mazelas, destacamos algumas questões. A subnutrição é sublinhada em vários casos, mas o tamanho reduzido das posses, a expulsão dos territórios, as barragens que interferem sobre a piscosidade dos rios nos permitem supor que a maioria das comunidades e povos apresentados sofre uma grande insegurança alimentar e nutricional. 
Outro grande problema diz respeito à contaminação e salinização de aquíferos, de origem industrial ou agrícola, compreendendo as plantações de eucaliptos e a carcinicultura. Chama a atenção o fato de que nem sempre as suspeitas de contaminação são pesquisadas e, mais ainda, que não há registro, na área da saúde, sobre a apuração das evidências coletadas. Por exemplo, no caso da Votorantim Metais, no rio São Francisco, em Minas Gerais, "a Fundação Jorge Duprat Figueiredo, de Segurança e Medicina do Trabalho (Fundacentro), órgão vinculado ao Ministério do Trabalho e Emprego, realizou exames na população e constatou contaminação por arsênio, manganês e zinco", mas não sabemos que providências foram tomadas. Pode ser um problema da pesquisa sobre o caso, na qual não se teria conseguido reunir todas as informações relevantes, apesar de o estado da saúde pública no país permitir indagar se essa ausência documental não significa efetivamente a ausência de intervenção dos órgãos de saúde nesses casos.

Carlos Frederico Marés Souza Filho (1999), em artigo seminal, menciona o romance de Manuel Scorza, Garabombo: o invisível, em que o protagonista ficava invisível diante das autoridades ao reivindicar o reconhecimento do seu povo, representando metaforicamente a situação de invisibilidade do coletivo e da negação dos seus direitos.

A Fundação Nacional de Saúde (Funasa) é objeto de queixa em numerosos casos. Terceirização, descaso, negligência, falta de estruturas e equipamentos, burocratização, não liberação das verbas, falta de transparência, de participação na gestão e de prestação de contas, má gestão, presença esporádica de profissionais da saúde e descontinuidade no atendimento levam a saúde dos povos indígenas e comunidades tradicionais a uma situação de calamidade e põem em risco a sobrevivência de muitos. Felizmente, as denúncias dos escândalos desencadeiam reações por parte das autoridades, principalmente quando a exigência de substituição de funcionários e chefias se acompanha de detenções de funcionários ou de ocupações na Funasa ou na Funai.

É nesse sentido que escrevemos 'felizmente'. As fortes reações desses povos não são outra coisa senão a vontade de serem verdadeiramente reconhecidos e de experimentarem a democracia pela exigência dos seus direitos. São a antítese de aparelhos públicos antirrepublicanos, quando estes são apropriados por certos interesses particulares ou paralisados por uma burocracia dissociada da noção de serviço público. 


\section{Conclusão}

Os conflitos entre povos tradicionais e Funasa chamam a atenção por sua dimensão coletiva. A injustiça ambiental atinge comunidades inteiras e, por isso, provoca a reação coletiva.

Esse coletivo não se limita à comunidade ou ao povo atingido, mas se amplia do plano local ao nacional, incorporando organizações afins de base popular ou sindical, entidades representativas intermediárias e nacionais, organizações não governamentais (ONGs), redes de entidades, agências alternativas de notícias, pesquisadores ou instituições de ensino e pesquisa, setores de administrações regionais e/ou nacionais, Ministério Público etc. Nossa experiência nos faz afirmar que, por causa desses coletivos, os casos não ficam abafados na esfera local. Se os órgãos regionais de imprensa estão presentes, a mídia nacional dá pouco espaço a esses conflitos e chega mesmo a hostilizar grupos atingidos. Porém, observamos, muitas vezes, pesquisadores que sustentam as denúncias em seus estudos.

O outro lado também não se limita aos diretamente interessados, como já visto. $\mathrm{O}$ círculo do poder que promove a injustiça se estende também do local ao nacional. Essa poderosa aliança congrega setores dos executivos e legislativos, das polícias e dos judiciários, entidades representativas do setor privado, em particular federações e a confederação que representa o agronegócio, da imprensa escrita e falada (seja porque apoiam, seja porque silenciam os casos). E a tais setores convém agregar a maioria da população que se ancora na ideologia do desenvolvimento e na profunda desigualdade, oriunda dos resquícios da escravidão e da luta de classes capitalista.

Que contradições o Brasil está vivendo? As poderosas coalizões, que buscam eliminar do mapa ou reduzir a reservas (as menores possíveis) povos indígenas e comunidades tradicionais, parecem considerá-los elementos sobreviventes do passado, arcaicos obstáculos ao progresso. $\mathrm{O}$ crescimento econômico, na perspectiva dessa aliança, se sobrepõe aos direitos econômicos, sociais, culturais e ambientais. Em nome dele, passa-se por cima dos direitos fundamentais: à liberdade, à opinião, à vida.

Se entendermos o Mapa de Conflitos como síntese das relações socioambientais e de justiça ambiental - cultural, histórica, simbólica e econômica - dos territórios, ancestralmente ocupados pelos povos e comunidades tracionais e indígenas, com sua diversidade de paisagens, usos e práticas extrativistas, ele pode se apresentar como alternativa para auxiliar na inversão do processo desastroso de aquecimento global. Ao proporcionar informações para fundamentar políticas públicas sistematizadas na Conferência Nacional 
de Saúde Ambiental, o mapa colabora, nas metodologias de pesquisas e de implementação de políticas públicas, a aprimorar as questões de qualidade de vida, soberania alimentar e saúde comunitária, em grande parte, construídas e anunciadas pelos atingidos.

Segundo Dantas (2010), "a inserção social tirou milhões da miséria. É preciso discutir, agora, como fazê-los participar, sem favores, de uma economia produtiva". E continua:

De 2004 a 2009, a proporção de pobres brasileiros caiu de 39,4\% para 23,9\%, e a proporção de miseráveis foi reduzida à metade, de $17,5 \%$ para $8,4 \%$, de acordo com as linhas de pobreza e indigência utilizadas por Ricardo Paes de Barros do Instituto de Pesquisa Econômica Aplicada (Ipea).

A pobreza se reduz, de um lado e, de outro, se reproduz. Para além do Programa Bolsa Família, quer-se introduzir na economia ativa os que estão saindo da miséria, mas simultaneamente destrói-se a economia de outros. Onde estarão amanhã os grupos sociais excluídos ou submetidos a permanentes exações? Recebendo benefícios do Bolsa Família e saindo eles também da situação de miséria? Esqueceremos direitos e justiça e bateremos palmas?

Restam algumas perguntas. Percebe-se no relato dos casos uma impressionante história de resistência. Esses povos e comunidades não querem morrer e desaparecer. Será que o crescimento e a submissão da vida aos parâmetros da economia dominante são os únicos discursos possíveis? As crises ambientais e socioambientais que se avolumam não obrigam a repensar o futuro? Essas populações não têm algo a dizer sobre esse futuro? 


\section{Referências}

ALMEIDA, A. W. Agroestratégias e desterritorialização: direitos territoriais e étnicos na mira dos estrategistas dos agronegócios. In: ALMEIDA, A. W. et al. (Orgs.). Capitalismo Globalizado e Recursos Territoriais: fronteiras de acumulação no Brasil contemporâneo. Rio de Janeiro: Lamparina, 2010a.

ALMEIDA, A. W. Direitos territoriais e étnicos: as estratégias do agronegócio na Amazônia. In: ZHOURI, A. \& LASCHEFSKI, K. (Orgs.). Desenvolvimento e Conflitos Ambientais. Belo Horizonte: Editora UFMG, 2010b.

ALMEIDA, A. W. et al. Mapeamento social como instrumento de gestão territorial contra o desmatamento e a devastação. Processos de capacitação de povos e comunidades tradicionais, Caderno de Debates Nova Cartografia Social - conhecimentos tradicionais e territórios na Pan-Amazônia, 1(1): 125-138, 2010.

ACSELRAD, H. Apresentação: conflitos ambientais - a atualidade do objeto. In: ACSELRAD, H. (Org.). Conflitos Ambientais no Brasil. Rio de Janeiro: Relume Dumará, 2004.

ACSELRAD, H. Mapeamentos, identidade e territórios. In: ACSELRAD, H. (Org.). Cartografia Social e Dinâmicas Territoriais: marcos para o debate. Rio de Janeiro: Ippur/UFRJ, 2010.

ACSELRAD, H.; CAMPELlO, C. \& BEZERRA, G. O que É Justiça Ambiental. Rio de Janeiro: Garamond, 2009.

ACSELRAD, H.; HERCULANO, S. \& PÁDUA, J. A. A justiça ambiental e a dinâmica das lutas socioambientais no Brasil: uma introdução. In: ACSELRAD, H.; HERCULANO, S. \& PÁDUA, J. A. (Orgs.). Justiça Ambiental e Cidadania. 2. ed. Rio de Janeiro: Relume Dumará, 2004.

BOURDIEU, P. Esquisse d'une Théorie de la Pratique. Paris: Droz, 1972.

BRASIL. Presidência da República. Decreto n. 6.040 de 7 de fevereiro de 2007. Casa Civil. Disponível em: <www.planalto.gov.br/ccivil_03/_ato2007-2010/2007/decreto/d6040.htm>. Acesso em: 22 maio 2013.

DANTAS, F. A construção de um país além da bolsa. O Estado de S. Paulo, São Paulo, 27 set. 2010.

LEROY, J. P. Territórios do Futuro: educação, meio ambiente e ação coletiva. Rio de Janeiro: Lamparina, 2010.

SACK, R. D. Human Territoriality: its theory and history. New York: Cambridge University Press, 1986.

SOUZA FILHO, C. F. M. Os direitos invisíveis. In: OLIVEIRA, F. \& PAOLI, M. C. (Orgs.). Os Sentidos da Democracia: políticas do dissenso e hegemonia global. Petrópolis: Vozes, 1999. 


\section{4}

\section{Injustiça Ambiental no Campo e nas Cidades: do agronegócio químico-dependente às zonas de sacrifício urbanas}

Marcelo Firpo Porto

Um Olhar Integrado sobre as Injustiças Ambientais no Campo e nas Cidades

_ ste capítulo cumpre uma dupla função: discutir, de um lado, os conflitos ambientais registrados no Mapa de Conflitos Envolvendo Injustiça Ambiental e Saúde no Brasil (ou Mapa de Conflitos) ${ }^{1}$ e relacionados aos territórios do campo e das florestas, em particular aqueles vinculados à expansão dos monocultivos e seus impactos, como o uso intensivo de agrotóxicos; e, de outro, os conflitos presentes nos territórios urbanos.

Além da enorme relevância do agronegócio no modelo de desenvolvimento hegemônico no país, dada a importância produção de commodities rurais, como soja, madeira, carnes e outros produtos de origem econômica da agropecuária, desde 2008 o Brasil tem recebido o lamentável título de principal consumidor mundial de agrotóxicos (Soares, 2010). Monocultivos representam a negação da agroecologia e da agricultura familiar justa e sustentável; a biodiversidade é compreendida como 'praga' a ser combatida numa guerra química contra a natureza, marcando o caráter químicodependente desse modelo de produção agrícola que pretende transformar a natureza em um grande empreendimento fabril.

\footnotetext{
${ }^{1}$ Disponível em: <www.conflitoambiental.icict.fiocruz.br>.
} 
Entramos no século XXI marcados pela expansão dos monocultivos, padrão exemplar de produção do agronegócio capitalista voltado para o comércio internacional em uma economia globalizada. Atualmente $90 \%$ da produção mundial de alimentos são provenientes de apenas 15 espécies vegetais e oito animais, e "um sistema ecológico homogêneo é um desastre esperando para acontecer" (Holling apud Giampietro, 2002: 468). Não casualmente, a expansão dos monocultivos é a principal atividade econômica geradora de conflitos e injustiças ambientais no mapa, com 33,3\% dos casos. Isso porque a atuação de entidades governamentais, importante causadora de injustiças, não se caracteriza como um setor produtivo específico, embora sirva de suporte político e institucional ao modelo econômico hegemônico, em vez de servir de instrumento de proteção aos direitos fundamentais das populações e cidadãos atingidos por esse modelo, como deveria acontecer.

Em relação ao segundo foco deste capítulo - os conflitos presentes nas cidades e nos territórios urbanos -, cabe relembrar que foram nesses espaços que surgiram, nos Estados Unidos, a partir de 1978, os primeiros movimentos sociais e intelectuais em que se passou a utilizar expressões como 'racismo ambiental', 'injustiça ambiental' e 'zona de sacrifícios'. Tais movimentos denunciam, desde então, as situações nas quais grupos populacionais discriminados, como negros, trabalhadores, grupos étnicos e mulheres, sofrem com as principais cargas ambientais de um modelo de desenvolvimento iníquo. São principalmente essas populações que moram em locais (ou neles circulam ou trabalham) como lixões, aterros de rejeitos, fábricas perigosas e poluentes, áreas de riscos de inundação ou desabamento ocasionados por chuvas torrenciais, ou, ainda, estradas com trânsito intenso, poluição decorrente dos veículos e riscos de acidentes de trânsito, como atropelamentos.

No Brasil, muitos conflitos se aproximam das características dos movimentos iniciais por justiça ambiental nos Estados Unidos, envolvendo questões como poluição industrial, proximidade de indústrias perigosas e de lixões. Tais conflitos ambientais urbanos tendem a se intensificar não só como reflexo da intensa urbanização e industrialização no país, mas também como resultado da incorporação das discussões sobre justiça ambiental por movimentos sociais urbanos. Porém, os centros urbanos latino-americanos apresentam outras características típicas importantes relacionadas à precariedade das políticas e dos serviços públicos, como a falta de saneamento, de moradia e transporte adequados, de serviços básicos de saúde, e a existência de áreas de risco de inundações e desmoronamentos em periferias urbanas e favelas, o que torna ainda mais perigoso viver nas 
zonas de sacrifício. $\mathrm{Ou}$, ainda, a presença de comunidades quilombolas e indígenas em espaços urbanos, além das pressões decorrentes da especulação imobiliária que geram remoções, intensificadas mais recentemente pela iminência de grandes eventos, como a Copa do Mundo e as Olimpíadas.

Existe, porém, outro motivo importante para a análise desses dois territórios e conflitos em um único capítulo: buscamos evidenciar que as questões urbanas têm uma intrínseca relação com as rurais, e que a busca por sociedades mais justas, sustentáveis e democráticas implicará repensarmos simultaneamente novas formas de relação entre as populações e os territórios urbanos, rurais e tradicionais, entre as cidades e os ecossistemas que as sustentam, sejam estes próximos ou distantes, por vezes em outros continentes, diante de cadeias produtivas e um comércio crescentemente globalizado. Essa compreensão também acarreta novos diálogos e convergências entre movimentos sociais e sujeitos coletivos nos campos, florestas e cidades em diferentes escalas, possibilitando a construção de pautas comuns e políticas públicas em torno de resistências e utopias em que se reconheçam os imensos desafios ambientais e sociais contemporâneos.

\section{Caracterizando os Espaços Rural e Urbano e suas Interações na Produção de Conflitos}

O Gráfico 1 apresenta a evolução da população brasileira rural e urbana entre 1900 e 2000 e evidencia a forte relação entre concentração fundiária, êxodo rural e expansão da população urbana. Em um século, a proporção se inverte radicalmente: em 1900 a população rural era dez vezes superior à urbana, e em 2000 a população urbana passa a ser 4,3 vezes maior.

Com a crescente complexidade das dinâmicas econômicas e sociais do Brasil nas últimas décadas, vários autores têm mencionado problemas na visão clássica que reforça a dicotomia urbano-rural, principalmente em regiões com maior densidade populacional e proximidade de regiões metropolitanas. Para Aurílio Sérgio Caiado e Sarah Maria dos Santos (2001), fenômenos como a conurbação, a metropolização e a expansão da ocupação urbana em áreas oficialmente definidas como rurais mostram que a definição oficial do Instituto Brasileiro de Geografia e Estatística (IBGE) de regiões rurais e urbanas não é mais suficiente para explicar a complexa situação demográfica do Brasil contemporâneo.

Da mesma forma, Maria de Nazareth Wanderley (2000) e Ângela Duarte Ferreira (2002) discutem os limites da definição oficial diante da complexidade do tema, já que as instituições governamentais, como o IBGE, tendem a 
definir como rural tudo aquilo que não é uma aglomeração dotada de alguns serviços. Alguns estudos recentes evidenciam esse equívoco e mostram a forma como, independentemente do tamanho, todos os municípios têm áreas urbanas e rurais, e estas são caracterizadas normalmente por habitações dispersas, embora diversos espaços sejam considerados urbanos sem que, de fato, ofereçam experiências urbanas a seus habitantes. Há também distritos classificados como urbanos, embora, na realidade, a sua população seja voltada para atividades rurais.

Gráfico 1 - Distribuição da população rural e urbana (em milhões). Brasil - 1900-2010

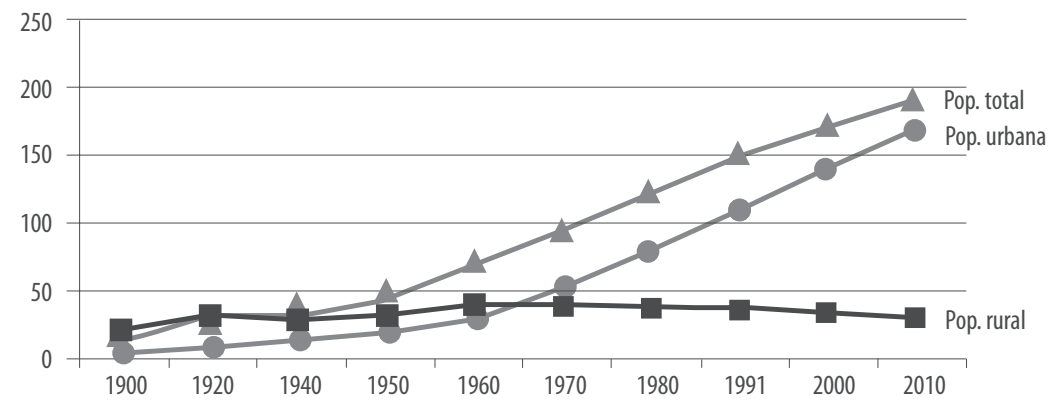

Fonte: IBGE, 2010.

O conceito 'aglomerado subnormal', usado pelo IBGE nos últimos censos para se referir a espaços das periferias nas cidades, chamados 'favelas' ou similares, ainda que marcado pela operacionalidade, é também extremamente inadequado, além de preconceituoso. Segundo o IBGE, o setor censitário definido como aglomerado subnormal

é um conjunto constituído de, no mínimo, 51 unidades habitacionais (barracos, casas...), ocupando ou tendo ocupado, até período recente, terreno de propriedade alheia (pública ou particular) dispostas, em geral, de forma desordenada e densa, bem como carentes, em sua maioria, de serviços públicos essenciais. (IBGE apud Silva et al., 2009)

Portanto, as relações entre o rural e o urbano e o processo de urbanização brasileira, por vezes com taxas maiores que as de vários países europeus, devem ser examinadas com cuidado: é impossível estabelecer padrões homogêneos - internos ou relacionais - entre o rural e o urbano diante de realidades consideradas rurais tão diversas nas várias regiões do país: a presença de biomas/ecossistemas; a existência de áreas preservadas; a extensão dos vários tipos de áreas de preservação ambiental previstas em lei, sejam 
elas de proteção integral, como os parques nacionais, ou de uso sustentável, como as áreas de proteção ambiental e as reservas extrativistas; as histórias de ocupação; os tipos de empreendimentos econômicos existentes no passado e no presente; a relação de distância (proximidade ou afastamento) de grandes centros urbanos; a existência de populações e comunidades tradicionais e suas culturas fortemente marcadas pela relação com a natureza, incluindo-se povos indígenas, quilombolas, extrativistas, ribeirinhos e ainda vários grupos, para muitos, desconhecidos, como os geraizeiros e vazanteiros do norte de Minas Gerais e os faxinalenses do oeste do Paraná; a prática de agricultura familiar e/ou de monocultivos do agronegócio, entre outras variáveis. $\mathrm{O}$ amálgama desse conjunto se encontra em inúmeros movimentos culturais e sociais que caracterizam os territórios no país, palco da diversidade e celebração da vida, mas também de conflitos e resistências levantados no Mapa de Conflitos.

Para pensarmos as relações entre campo e cidade, é importante levar em conta o fato de os espaços rurais se constituírem como as áreas mais protegidas e de vitalidade dos ecossistemas, ainda que com diferentes estágios de preservação ou, pelo contrário, de degradação ambiental e esgotamento de recursos naturais. Como amplamente reconhecido nos estudos sobre os ecossistemas, estes geram importantes processos ecológicos essenciais de suporte e benefício à vida em distintas escalas, do nível local ao regional e planetário. Dessa forma, as cidades e conglomerados urbanos, mesmo que pressionem os ecossistemas de diferentes maneiras para obter recursos, tais como energia, alimentos, matérias-primas para as distintas cadeias produtivas e modos de consumo, são dependentes de sua vitalidade para a qualidade da própria vida humana.

Uma forma de entender os sistemas de suporte e benefício à vida, gerados pelos ecossistemas, é observar a sua classificação em quatro grandes grupos: provisão - de alimentos, de água potável, de combustíveis, de fibras, de compostos bioquímicos e de recursos genéticos; regulação - do clima, dos ciclos de águas (que são também purificadas), da degradação dos solos; suporte - à formação dos solos e ciclos de nutrientes (produção primária); e sistemas culturais e simbólicos - benefícios imateriais, tais como lazer e turismo, valor espiritual e religioso, estéticos, educacionais, herança cultural, sensação de lugar e seu pertencimento (Andrade \& Romeiro, 2009).

Do ponto de vista ecossistêmico e social, as transformações no campo têm inúmeras interações e impactos no mundo urbano e vice-versa. Por exemplo, a intensificação de processos de produção e consumo nos territórios urbanos repercute no mundo rural, pois a demanda pelo consumo de carne, aço ou 
energia elétrica acarreta pressões que favorecem a expansão de monocultivos de grãos, desertos verdes (monocultivos de eucaliptos e pinus), minerações ou hidrelétricas que podem afetar os ecossistemas, os territórios e as populações que neles se inserem.

Além disso, a degradação ambiental decorrente dessas atividades pode provocar problemas de segurança hídrica e química (caso das contaminações por agrotóxicos), redução da biodiversidade e diversas consequências associadas à provisão, regulação e suporte produzidos pelos ecossistemas, cujas consequências não se restringem ao espaço rural distante do urbano. Verificamos essa questão observando a extrema vulnerabilidade que várias metrópoles do litoral, além de São Paulo (SP) e Belo Horizonte (MG), apresentam com relação à sua segurança hídrica que depende, em boa parte, do que ainda resta da Mata Atlântica da região.

Os efeitos da degradação dos ecossistemas atingem escalas regionais e mesmo planetárias, fenômeno esse relacionado à produção dos chamados 'riscos ecológicos globais'. Por exemplo, a perda de biodiversidade, a degradação e a poluição ambiental por gases de efeito estufa em diversas áreas do planeta estão diretamente relacionadas às mudanças climáticas globais. Outro tipo de impacto relevante em termos de escalas mais globais diz respeito à contaminação química dos alimentos decorrente do uso intensivo de agrotóxicos, que afeta, além de trabalhadores e famílias rurais, consumidores dos alimentos nas cidades; ou ainda à poluição transfronteiriça, que afeta populações de espécies em áreas extremamente distantes dos locais originais da poluição, como os ursos polares contaminados pelo pesticida Dicloro-Difenil-Tricloroetano (DDT) no Ártico.

Outro exemplo atual da forma como as interações campo-cidade podem intensificar conflitos ambientais diz respeito à crescente demanda por biocombustíveis para uso em veículos, em especial o etanol. A área plantada com cana-de-açúcar no Brasil passou de 4,88 milhões de hectares em 2000 para 8,21 milhões em 2008, com aumentos mais expressivos nas Regiões Sudeste, Centro-Oeste e Sul (Assis, 2010).

Uma parte significativa do aumento de quase $70 \%$ da área plantada no período se deve às demandas por etanol usado como biocombustível no país, com perspectivas crescentes de uso no cenário internacional. Agrocombustíveis, como o etanol e o biodiesel, têm sido propalados por organizações e autoridades de distintos países como alternativas energéticas importantes para a redução de gases de efeito estufa, embora sejam controversos tais argumentos (Brianezi, 2010). 
Tendo-se como foco apenas o etanol, de acordo com o Ministério do Desenvolvimento, Indústria e Comércio Exterior, o advento dos veículos flex fuel, que usam simultaneamente gasolina e álcool, gerou um aumento significativo no consumo de álcool hidratado no Brasil, que passou de 4,3 bilhões de litros em 2003 para 15 bilhões em 2010 (Brasil, 2011). ${ }^{2}$ Segundo essa mesma fonte, os principais países que importam do Brasil são os Estados Unidos, Japão, Jamaica, Nigéria, Coreia do Sul, Suécia, Países Baixos, Costa Rica, El Salvador e México.

Ao mesmo tempo que se intensifica a produção do 'combustível verde', Maria Aparecida de Moraes Silva (2006) mostra que a mudança da cartografia migratória de trabalhadores para os canaviais de São Paulo se deu entre 2000 e 2006 "em razão do avanço do agronegócio da sojicultura e pecuária, responsáveis pelo processo de expropriação do campesinato dessa região, de um lado, e, do outro, do sucroalcooleiro paulista, demandante de grandes contingentes de força de trabalho" (Silva, 2006: 114).

Ainda que os fluxos migratórios campo-cidade tenham se reduzido bastante com relação às décadas anteriores, a expansão dos monocultivos da cana, da soja e a própria agropecuária continuam gerando dinâmicas extremamente perversas para as populações rurais em várias regiões do país, com impactos nas regiões urbanas relacionados à formação das desigualdades sociais que marcam periferias e favelas nas cidades. Continua a existir, portanto, uma forte interdependência entre as dinâmicas urbanas e rurais. E, na busca por sustentabilidade ambiental e justiça social e ambiental, necessariamente se devem articular movimentos sociais com procura por alternativas relacionadas aos modelos de desenvolvimento, tanto no campo como nas cidades.

\section{Expansão do Agronegócio, Monocultivos e Uso de Agrotóxicos}

Segundo a Organização das Nações Unidas para Agricultura e Alimentação (FAO, 2007), embora o Brasil ainda tenha uma área de agricultura menor que a da Índia, China e Estados Unidos, a disponibilidade de áreas preservadas ou de pastagens consideradas potencialmente aráveis é avaliada como a maior do mundo, e é por isso um foco das atenções do agronegócio voltado para o comércio global e para a produção de commodities agrícolas. A expansão dos monocultivos e do agronegócio de exportação tem sido responsável por

\footnotetext{
${ }^{2}$ Ver: $<$ www.desenvolvimento.gov.br/sitio/interna/interna.php?area $=2 \&$ menu=3652>.
} 
inúmeros impactos socioambientais e de saúde pública que se encontram por trás dos numerosos conflitos ambientais no campo. Entre os possíveis impactos, podemos destacar (Rigotto, 2009; Pignati, 2008; Carneiro et al., 2008; Porto \& Milanez, 2009; Almeida, Petersen \& Cordeiro, 2001):

1) concentração de terras, renda e poder político dos grandes produtores na disputa de terras e projetos de desenvolvimento nos territórios onde vivem e trabalham as populações campesinas, de pequenos agricultores, indígenas, quilombolas, extrativistas, ribeirinhos e tantos outros grupos tradicionais do campo e da floresta;

2) violência e impunidade no campo, com assassinatos de líderes, exploração da mão de obra, incluindo-se o trabalho escravo e infantil e mortes por exaustão nos canaviais;

3) perda de terra, o desemprego no campo e o fluxo migratório campocidade, favorecendo o caos urbano e das regiões metropolitanas;

4) consequências negativas sobre a segurança e soberania alimentar, principalmente quando as mercadorias agrícolas são exportadas para os países mais ricos (caso da soja, básica como ração para a produção de proteína animal) ou estão submetidas a cadeias produtivas que não a de alimentos (caso dos biocombustíveis, como o etanol, ou da plantação de árvores para o uso em siderúrgicas ou fábricas de celulose);

5) problemas associados à contaminação química decorrente do uso intensivo de agroquímicos, em especial os agrotóxicos, uma das marcas da 'modernização agrícola' brasileira.

Em 2006, o Censo Agropecuário apurou (IBGE, 2009) que os 5.175.489 estabelecimentos agropecuários ocupavam 329.941.393 hectares, o equivalente a $36,75 \%$ do território brasileiro (851.487.659 hectares). Como podemos verificar no Gráfico 2, o território brasileiro inclui, além dos estabelecimentos rurais, áreas de terras indígenas, de unidades de conservação e outras ocupações, e apenas uma pequeníssima parte é considerada área urbanizada. Portanto, existe uma grande disputa por terras não somente entre os estabelecimentos rurais, com uma forte concentração fundiária, mas também envolvendo a expansão dos monocultivos sobre as pequenas propriedades e áreas de assentamento agrário, além das pressões sobre unidades de conservação, terras indígenas e quilombolas, entre outros fatores que marcam os conflitos por terra. 
Uma característica central das áreas rurais no Brasil, em consonância com a presença marcante dos monocultivos no modelo agrícola hegemônico, é a enorme concentração fundiária. Estudos feitos por Paulo Alentejano (2011), geógrafo dedicado ao tema da reforma agrária no Brasil, revelam que os estabelecimentos com mais de 100 ou 1.000 hectares, embora representem um percentual reduzido, ocupam um enorme espaço da área total, cerca de $80 \%$, e a maioria dos grandes estabelecimentos está concentrada em monocultivos e atividades pecuárias. Os imóveis rurais com mais de 5.000 hectares $(0,2 \%$ deles $)$ ocupam mais de $13 \%$ da área total, e os com mais de 1.000 (1,5\%) ocupam 30,3\% da área total.

Embora a enorme desigualdade na distribuição da posse da terra no Brasil seja um fato, é difícil analisar as tendências atuais com precisão com base nos dados dos últimos censos agropecuários, já que a questão da concentração fundiária é complexa e os censos apresentam diferenças na forma de levantar as informações. Um importante indicador da concentração fundiária é o índice de Gini de distribuição de terra. Esse índice mede o grau de desigualdade na distribuição de terra ou de renda, variando de 0 a 1; quanto maior o índice, maior a desigualdade.

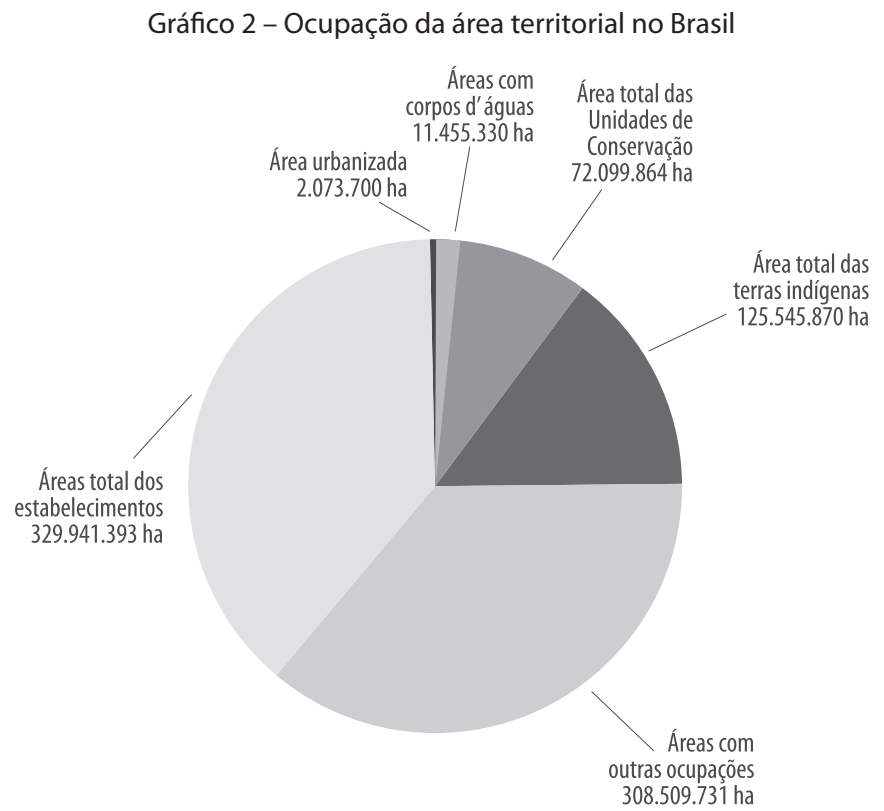

Fonte: IBGE, 2009. 
Contudo, como apontam Rodolfo Hoffmann e Marlon Ney (2010), é necessário fazer uma distinção entre desigualdade e concentração fundiária: o que caracteriza a desigualdade é a grande proporção da área total ocupada por uma pequena proporção dos estabelecimentos em relação a outras de menor tamanho. Em termos hipotéticos, podemos ter uma situação em que existiria apenas um pequeno número de grandes propriedades, todas com o mesmo tamanho. Nesse caso, a desigualdade seria nula (índice de Gini igual a 0), embora houvesse uma grande concentração fundiária na qual a maior parte da população não teria terra para plantar. Da mesma forma, em uma região onde existem apenas latifúndios, a desapropriação de uma grande propriedade e sua distribuição em pequenos lotes para assentamentos curiosamente aumentaria a desigualdade (índice de Gini maior que 0), embora houvesse uma redução da concentração fundiária.

Essa explicação nos ajuda a entender a dificuldade de analisarmos as tendências das desigualdades com base nos dados do Censo Agropecuário do IBGE (2006), pois ele evidencia uma tendência de estabilidade na desigualdade em relação aos censos anteriores. Contudo, isso decorre, em grande parte, em razão do efeito do crescimento do número de pequenos estabelecimentos, e não pela desconcentração fundiária. Pelo contrário, a proporção da área ocupada pelos 5\% maiores estabelecimentos continua crescendo: em 2006 chegou a 68,4\%, ao passo que os 50\% menores ocupam apenas $2,7 \%$, ou seja, 25,3 vezes menos que as grandes propriedades.

Os estados com maior concentração fundiária no último censo foram, nesta ordem, Alagoas, Maranhão, Mato Grosso, Ceará, Mato Grosso do Sul, Piauí, e Amapá, mesclando regiões tradicionalmente pobres e desiguais com áreas de expansão da fronteira agrícola (Hoffmann \& Ney, 2010). A concentração fundiária e a expansão dos monocultivos são responsáveis pelas disputas por terra nos territórios rurais e se constituem em um elemento central para compreendermos a geração de conflitos no campo.

Apesar da concentração fundiária, dados do último Censo Agropecuário do IBGE (2006) continuam mostrando a importância de pequenos estabelecimentos rurais e da agricultura familiar, incluindo-se assentamentos da reforma agrária. Embora a soma das suas áreas represente apenas 30,31\% do total, os pequenos estabelecimentos responderam por $84,36 \%$ das pessoas ocupadas em estabelecimentos agropecuários. Mesmo que cada um deles gere poucos postos de trabalho, os pequenos estabelecimentos (área inferior a 200 ha) empregam 12,6 vezes mais trabalhadores por hectare que os médios (área entre 200 e inferior a 2.000 ha) e 45,6 vezes mais que os grandes 
estabelecimentos (área superior a $2.000 \mathrm{ha}$ ); sendo que os produtores e seus parentes representam $77 \%$ (ou 12.801.179) do total de ocupados nos pequenos estabelecimentos agropecuários.

Com relação à produção de alimentos e à soberania alimentar, os dados do Censo Agropecuário 2006 confirmam a enorme importância da agricultura familiar na produção de vários produtos, ficando responsável por $87 \%$ da produção nacional de mandioca, $70 \%$ de feijão, $46 \%$ do milho, $38 \%$ do café, $34 \%$ do arroz, $58 \%$ do leite, $59 \%$ do plantel de suínos, $50 \%$ das aves, $30 \%$ dos bovinos e, ainda, $21 \%$ do trigo (IBGE, 2006). Não casualmente, a cultura com menor participação da agricultura familiar foi a soja (16\%), cuja produção típica para exportação provém de grandes estabelecimentos.

Uma consequência direta da expansão do agronegócio no modelo da chamada 'revolução verde' nas últimas décadas foi o enorme crescimento do consumo de agrotóxicos no país. O Estado brasileiro desempenhou um papel central ao condicionar o crédito rural à compra de agrotóxicos a partir da instalação de várias empresas multinacionais no final da década de 1970, principalmente nas Regiões Sul e Sudeste. O Brasil não foi exceção no cenário internacional da 'revolução verde'. Segundo a FAO, os incentivos governamentais fizeram parte de uma política mundial orientada por interesses de mercado para países em desenvolvimento, já que, dos 38 países em desenvolvimento analisados, 26 subsidiavam o uso de agroquímicos (FAO/IFA, 1999).

Um importante aspecto desse crescimento, além da expansão dos monocultivos químico-dependentes, foi o processo de aproximação e fusão de empresas do setor químico com as do setor agrícola, tanto as de produção de sementes transgênicas - caso da soja resistente ao herbicida glifosato quanto outras de comercialização e processamento industrial. Victor Pelaez, Fabio Terra e Leticia da Silva (2010) mostram o crescente grau de concentração da indústria de agrotóxicos entre décadas de 1980 a 2000, com as oito maiores empresas passando de 62,1 para 77,2 \% de participação no mercado.

Além da produção de cana-de-açúcar, café e laranja, a principal cultura do agronegócio brasileiro é o cultivo de grãos que, intensificado nas últimas décadas, representa a principal parcela na produção brasileira, com destaque para o da soja e o do milho. A soja se tornou uma grande commodity rural a partir dos anos 1980, impulsionando o agronegócio de exportação no período. Outra importante expansão do monocultivo ocorreu com a plantação de árvores, principalmente eucaliptos, para a produção de celulose ou como combustível (carvão vegetal) para a produção do ciclo ferro-aço. Embora 
vários técnicos e instituições governamentais denominem esse monocultivo de 'florestas plantadas', tais sistemas homogêneos estão longe de representar ecossistemas com biodiversidade. Pelo contrário, reduzem a sócio e a biodiversidade local e, por isso, de forma crítica, têm sido também nomeados 'desertos verdes' (Meirelles \& Calazans, 2006; Zhouri, 2008).

A Tabela 1 elaborada com base nos dados do Censo Agropecuário 2006, apresenta as principais culturas e respectivas despesas com agrotóxicos. Não é de se estranhar que os monocultivos são justamente os que mais os utilizaram, com destaque para a produção de soja e cana-de-açúcar, com despesas de 5 e 1,5 bilhões de reais, respectivamente. Contudo, a cultura da laranja foi a que proporcionalmente mais gastou com agrotóxicos, pois a cada $R$ \$ 1.000 gastos com a produção, $R$ \$ 230 são para a compra de agrotóxicos. Em relação à despesa com agrotóxicos por hectare, destacamos o algodão e a laranja, com gastos médios por hectare de $\mathrm{R} \$ 525$ e $\mathrm{R} \$ 1.782$, respectivamente.

Tabela 1 - Despesas com agrotóxicos segundo atividade econômica fiscal dos estabelecimentos agropecuários que utilizaram agrotóxicos - 2006

\begin{tabular}{|c|c|c|c|c|c|c|c|c|c|}
\hline \multirow{2}{*}{$\begin{array}{l}\text { Atividade } \\
\text { fiscal } \\
\qquad \frac{\stackrel{\varrho}{J}}{3}\end{array}$} & \multicolumn{4}{|c|}{ Despesas (R\$ milhões) } & \multirow{2}{*}{$\begin{array}{l}\text { (A/B) } \\
\overline{\bar{E}} \\
\approx \\
\approx\end{array}$} & \multirow{2}{*}{ 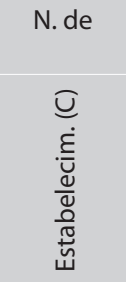 } & \multirow{2}{*}{ 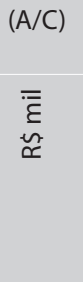 } & \multirow{2}{*}{ 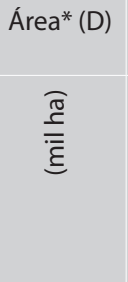 } & \multirow{2}{*}{$\begin{array}{l}(A) /(D) \\
\overline{\bar{\varepsilon}} \\
\stackrel{\sim}{\approx}\end{array}$} \\
\hline & $\begin{array}{l}\bar{\Xi} \\
\tilde{0} \\
\cdot \frac{u}{x} \\
00 \\
0 \\
0 \\
\frac{0}{0}\end{array}$ & d & $\begin{array}{l}\overline{\underline{0}} \\
\frac{\sqrt{\pi}}{\circ} \\
\text { D. }\end{array}$ & o & & & & & \\
\hline Soja & 5.020 & 37 & 40.584 & 26 & 124 & 129.129 & 39 & 14.441 & 348 \\
\hline $\begin{array}{l}\text { Cana-de- } \\
\text { açúcar }\end{array}$ & 1.520 & 11 & 29.434 & 19 & 52 & 23.088 & 66 & 4.641 & 328 \\
\hline Laranja & 1.217 & 9 & 5.383 & 3 & 226 & 16.939 & 72 & 683 & 1.782 \\
\hline Café & 786 & 6 & 11.719 & 7 & 67 & 87.617 & 9 & 1.614 & 487 \\
\hline $\begin{array}{l}\text { Algodão } \\
\text { herbáceo }\end{array}$ & 644 & 5 & 5.646 & 4 & 114 & 3.925 & 164 & 1.226 & 525 \\
\hline Milho & 568 & 4 & 6.864 & 4 & 83 & 147.857 & 3,8 & 2.803 & 203 \\
\hline Arroz & 215 & 2 & 3.438 & 2 & 63 & 42.257 & 5 & 1.403 & 153 \\
\hline Fumo & 164 & 1 & 2.520 & 2 & 65 & 121.632 & 1,3 & 840 & 195 \\
\hline Outros & 3.252 & 24 & 53.382 & 34 & 61 & 823.633 & 4 & 9.245 & 352 \\
\hline Total & 13.391 & 100 & 158.970 & 100 & 84 & 1.396 .077 & 9,6 & 36.896 & 363 \\
\hline
\end{tabular}

* Soma das áreas totais de lavouras dos estabelecimentos agropecuários segundo a sua classificação de atividade econômica fiscal ("atividade principal do estabelecimento").

Fonte: Porto \& Soares, 2012. 
Desde a criação de sua lista de discussão em 2002, circulam na Rede Brasileira de Justiça Ambiental (RBJA) diversas denúncias de casos de intoxicação aguda e contaminação crônica por agrotóxicos envolvendo trabalhadores rurais, de populações do campo vítimas de pulverizações aéreas e mesmo de desastres ambientais que atingiram populações de pescadores e moradores de cidades afetadas por rios contaminados. Há denúncias também da falta de treinamento de profissionais da área da saúde para o diagnóstico de contaminação química, assim como da ausência de um sistema de informações dentro do Sistema Único de Saúde (SUS) que possibilite relacionar os casos de intoxicação a uma mesma região, grupo exposto e período (RBJA, 2011).

Vários casos têm sido emblemáticos no contexto dos movimentos por justiça ambiental no Brasil, como o da Chapada do Apodi (CE), motivado pelo uso intensivo de agrotóxicos na fruticultura de exportação, gerando vítimas de intoxicação, mortes e problemas identificados como acidentes ambientais ampliados no município de Lucas do Rio Verde (MT), área marcada pela expansão da soja e pelas constantes pulverizações aéreas. Nesse município, em março de 2006, uma nuvem de agrotóxicos se espalhou sobre a cidade, destruindo vários jardins, pomares e hortas, e afetando a saúde da população local.

Na próxima seção, apresentaremos exemplos de conflitos registrados no mapa relacionados à expansão dos monocultivos e seus diversos impactos do ponto de vista dos direitos, do meio ambiente e da saúde das populações, especialmente relacionados ao uso de agrotóxicos.

\section{Conflitos Ambientais Relacionados aos Monocultivos nas Várias Regiões do País}

Desde sua criação, o tema do agronegócio, da expansão dos monocultivos e da contaminação por agrotóxicos sempre teve forte incidência nas discussões presentes na RBJA. Os conflitos registrados no mapa associados aos monocultivos estão em todas as Regiões, embora a aparente maior dispersão na Região Amazônica não expresse adequadamente a vastidão dos territórios envolvidos em conflito no Norte do país, marcado pela forte expansão da fronteira agrícola.

Os monocultivos estão relacionadas principalmente à produção de grãos (soja e milho, com o agravante da expansão da soja transgênica e do uso intensivo do agrotóxico glifosato), às árvores plantadas ou desertos verdes (eucalipto e pínus), aos biocombustíveis (cana-de-açúcar para o etanol e 
soja para o biodiesel), aos pastos para a produção extensiva de bovinos e, também, à fruticultura de exportação. Embora esta última tenha uma área comparativamente bem menor que as demais, seus efeitos socioambientais e danos à saúde também podem ser devastadores.

A expansão dos monocultivos no país, de acordo com os resultados do mapa, entra em conflito com povos indígenas, comunidades quilombolas, ribeirinhas, colônias de pescadores, posseiros e pequenos produtores, e também com os grupos ambientalistas que buscam defender os ecossistemas ameaçados. Os monocultivos são responsáveis por inúmeros problemas, como a ação de grileiros que disputam com povos tradicionais os territórios

Figura 1 - Conflitos ambientais relacionados aos monocultivos

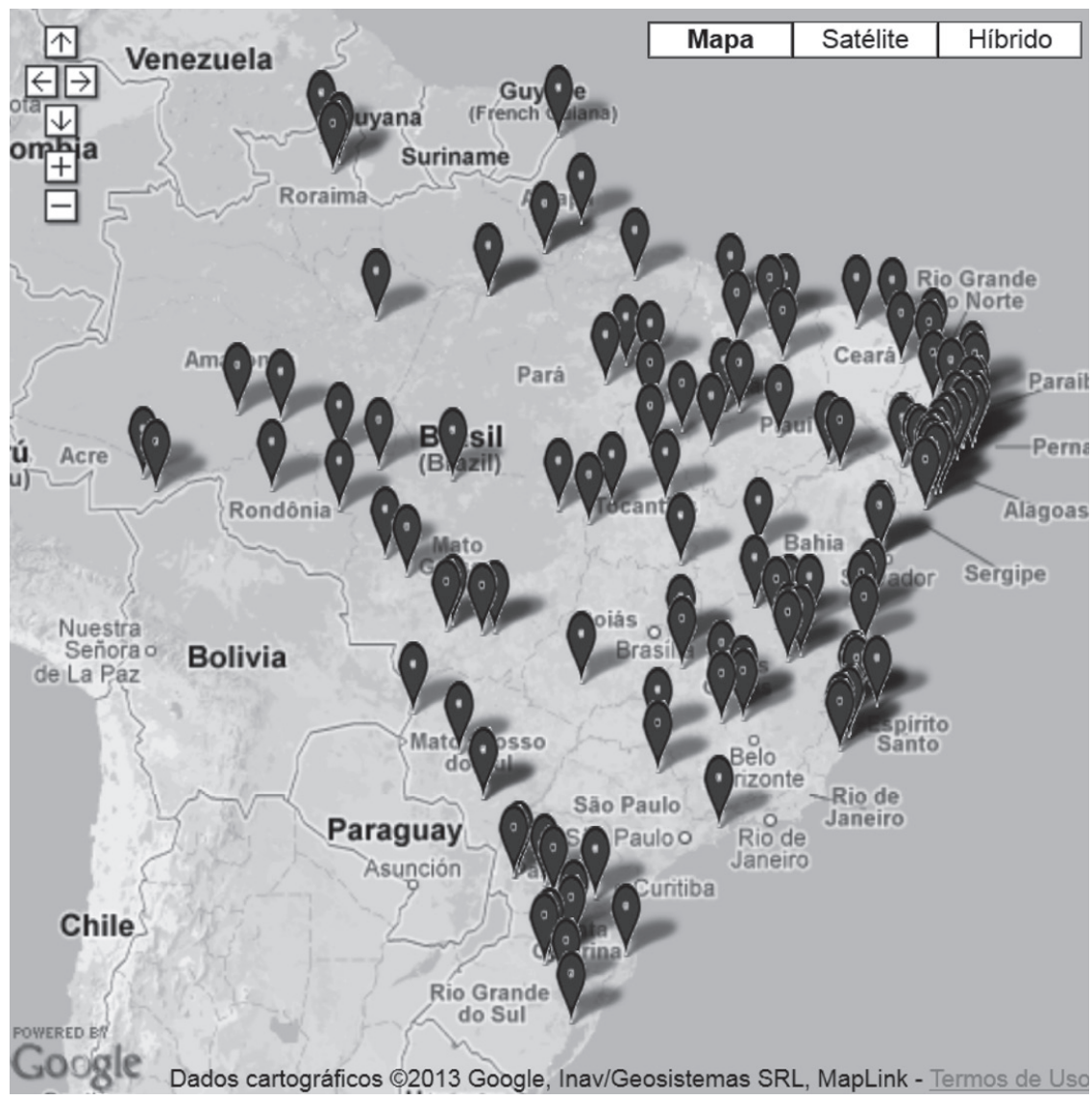

Fonte: Mapa de Conflitos Envolvendo Injustiça Ambiental e Saúde no Brasil. 
rurais e áreas da reforma agrária; a degradação dos ecossistemas que afeta principalmente as populações que dependem de sua vitalidade, como indígenas, quilombolas, comunidades tradicionais ${ }^{3}$ e agricultores voltados para a agroecologia; a contaminação por agrotóxicos das populações expostas, sobretudo os trabalhadores e moradores de áreas pulverizadas, ou ainda as populações atingidas por acidentes ambientais que afetam corpos hídricos e inúmeros municípios, e mesmo os consumidores de alimentos contaminados.

\section{Conflitos Ambientais na Região Amazônica: madeira, gado e soja}

Na Região Amazônica, além das pressões das hidrelétricas e da mineração, a expansão agrícola e os monocultivos estão presentes em todos os estados e influenciam, de forma mais intensa que em outras regiões, populações indígenas, quilombolas e extrativistas. Em Roraima, a invasão de posseiros e garimpeiros ameaça as terras dos Yanomami. Além da retomada de atividades garimpeiras desenvolvidas desde a década de 1980 e financiadas por empresários locais, os conflitos aumentaram com as invasões de fazendeiros de gado na região do Ajarani. No Amapá, a comunidade quilombola do Ambém, que desde 2007 espera pelo reconhecimento oficial de suas terras, sofre pressão de posseiros que provocam crimes ambientais, como queimadas e derrubada de árvores, limitando o acesso aos recursos naturais.

$\mathrm{Na}$ fronteira entre o Acre e o Amazonas, agricultores familiares são transformados em trabalhadores escravos em fazendas de criação de gado. A região, denominada 'arco do desmatamento', queengloba o suldo Amazonas, o noroeste de Rondônia e o norte de Mato Grosso, é intensamente afetada pela expansão das atividades de madeireiros, criadores de gado e fazendeiros de soja. Localizado nessa região cada vez mais vulnerabilizada pelo avanço do agronegócio, o município de Lábrea (AM) abriga comunidades ribeirinhas e extrativistas que lutaram pela criação e implementação das reservas extrativistas de Ituxi e do Médio Puruns, cujas conquistas continuam a ser ameaçadas em virtude da falta de fiscalização por parte dos órgãos competentes. Em Rondônia, no sul do Amazonas e no noroeste do Mato Grosso, vários povos indígenas da etnia Kanindé, como os Uru-Eu-Wau-Wau, têm sofrido

\footnotetext{
${ }^{3}$ Nas comunidades tradicionais, encontram-se os extrativistas, geraizeiros, vazanteiros, ribeirinhos, pescadores, faxinalenses, entre outros; todos afetados pela expansão dos monocultivos. Tal diferenciação é, por si, complexa: do ponto de vista legal e de políticas públicas, existem tanto legislações gerais como específicas, até mesmo para povos indígenas, quilombolas e comunidades tradicionais, assim como existem órgãos responsáveis por políticas públicas também específicas. Parte da complexidade dessa diferenciação se deve ao fato de boa parte dos quilombolas serem também agricultores, gerazeiros, vazanteiros, ribeirinhos, marisqueiros, catadores de caranguejos, entre outras classificações.
} 
com a invasão de madeireiros, garimpeiros e grileiros, nos ciclos econômicos que antecedem a chegada dos monocultivos de grãos.

Na região de Santarém (PA), a progressiva ocupação das terras do Planalto pelo monocultivo da soja e a grilagem das terras de várzea por fazendeiros e pecuaristas afetam agricultores e as comunidades quilombolas de Arepemã e Saracuna. Na mesma área, apesar da moratória acordada para não se expandir as plantações, com a construção do porto graneleiro pela multinacional Cargill para o escoamento da soja, as pressões sobre os pequenos produtores aumentam. Além de sofrerem os problemas causados por agrotóxicos, muitos são expulsos de suas terras.

\section{Conflitos Ambientais no Nordeste: de tudo, muito}

Da mesma maneira que a Região Amazônica, o Nordeste é afetado pelos problemas ocasionados pelos monocultivos, cuja origem histórica remonta à época da colonização com a cana-de-açúcar, mas, na atualidade, inclui novas fronteiras agrícolas, como a própria soja e a carcinicultura, ou fazendas de camarão. Na região de transição entre a Floresta Amazônica, o Cerrado e a Caatinga, estados como o Maranhão e o Piauí sofrem com a expansão da soja.

Embora oficialmente na Região Norte, introduziremos aqui o caso do Tocantins, que faz parte dessa região de transição e apresenta um caso paradigmático no município de Campos Lindos. O projeto de desenvolvimento agrícola envolve cerca de quarenta grandes produtores desde 1999, o que fez o plantio de soja saltar de 9,3 mil toneladas naquele ano para 127,4 mil em 2007, e essa expansão ocorreu sem nenhuma licença ambiental. Apesar desse enorme 'desenvolvimento', o município de Campos Lindos ocupou a primeira posição do país no Mapa de Pobreza e Desigualdade do IBGE (2008), com $84 \%$ da população abaixo da linha de pobreza. Mais ao norte, perto da fronteira entre o Pará e o Mato Grosso, o município de Mateiros ocupa o terceiro lugar no ranking nacional de produção de soja, mas 81,5\% de seus habitantes se encontram abaixo da linha de pobreza.

No Alto e Baixo Parnaíba, envolvendo os estados do Maranhão e Piauí, quilombolas e pequenos agricultores rurais têm sido confinados pelas grandes fazendas de soja e também são atingidos pela exposição aos agrotóxicos e ao uso de carvão vegetal para o processamento de alimentos. $\mathrm{O}$ ritmo de aceleração da soja é vertiginoso: somente no sul do estado do Maranhão a área plantada passou, entre 2003 a 2007, de 4 mil para 360 mil hectares. Antes da soja, a população local vivia basicamente do extrativismo (bacuri, buriti, mangaba e mel), caça, pesca e lavoura em sistema rotativo (arroz, milho, 
mandioca, feijão, fava, frutas etc.), favorecendo a segurança e soberania alimentar da região. Para tornar mais dramática a situação, em 2008 o Grupo Móvel de Fiscalização de Combate ao Trabalho Escravo, da Superintendência Regional do Trabalho e Emprego do Maranhão, resgatou de uma fazenda no município de Balsas nove trabalhadores em condição de trabalho escravo. No Piauí, as denúncias contra a expansão desordenada da soja transgênica no Cerrado piauiense e a consequente destruição, desmatamento e poluição do bioma local geraram várias ameaças a líderes locais.

O Vale do Jaguaribe (CE) apresenta um caso emblemático de injustiça ambiental vinculado à fruticultura de exportação. A política de irrigação em desenvolvimento desde a década de 1980 permitiu a instalação de empresas de exportação de melão e abacaxi, com uso intensivo de agrotóxicos e, consequentemente, inúmeros casos de contaminação do meio ambiente, de trabalhadores e da população exposta na região, até mesmo por pulverizações aéreas.

Trabalhos realizados na Universidade do Ceará, coordenados pela professora Raquel Rigotto (2009), evidenciam a existência de mortes diretamente associadas aos agrotóxicos. Os conflitos na região do Vale do Jaguaribe e a luta contra o agronegócio também produziram violências, que culminaram no assassinato, em abril de 2010, do agricultor, ambientalista e líder comunitário José Maria Filho, em Limoeiro do Norte. Atribui-se sua morte às denúncias que ele fazia sobre pulverizações aéreas com voos rasantes usadas também como forma de expulsar as comunidades, já que provocavam o envenenamento das pessoas, bem como das terras, águas e animais. Em 2012, o Ministério Público apresentou denúncia acusando de mandantes na morte do agricultor o dono e o gerente da empresa agrícola Frutacor.

O desenvolvimento da carcinicultura é outra causa importante de conflitos, não só no Ceará como em outros estados da Região. Casos emblemáticos ocorrem na comunidade do Cumbe, em Aracati (CE), onde vivem comunidades tradicionais de pescadores artesanais, catadores de caranguejos e marisqueiras atingidas pelas fazendas de camarão, que destroem o manguezal, ao mesmo tempo que degradam e desagregam as comunidades, convencendo-as a assumirem, elas próprias, a responsabilidade pela derrubada da mata, em troca da promessa de empregos. No caso do Cumbe, grande parte das fazendas foi abandonada após problemas de produtividade decorrentes de pragas nos camarões, deixando desoladas as localidades em que os investimentos prometiam um novo 'desenvolvimento'. Casos semelhantes aparecem no mapa nos estados da Paraíba, Rio Grande do Norte e Bahia. 
A plantação de cana-de-açúcar também, como não poderia deixar de ser, é fonte de conflitos em estados nordestinos produtores, como nos municípios de Joaquim Gomes, em Alagoas, e em Tracunhaém, em Pernambuco, onde se repetem as denúncias de condições de trabalho degradantes, ou ainda os impactos socioambientais no território de povos indígenas (Potiguara) e ribeirinhos na região de Rio Tinto, na Paraíba. Neste último caso, além das questões fundiárias, os conflitos são marcados pela poluição dos rios decorrente do despejo de vinhoto, um dos rejeitos da destilação da cana na produção de etanol.

\section{Conflitos Ambientais no Centro-Oeste: dos grãos à cana}

Reunindo conflitos que se assemelham aos da Região Norte e Nordeste, o Centro-Oeste é violentamente afetado pela soja, pela exploração de madeira, pelo plantio de cana-de-açúcar e pela pecuária bovina extensiva. Com a forte presença de comunidades indígenas e quilombolas, além de extrativistas e pequenos agricultores, a Região sofre com o forte crescimento dos monocultivos desde a década de 1990, principalmente de grãos.

Diversos povos indígenas no Mato Grosso são ameaçados pela ação de grileiros, madeireiros e pelo avanço dos monocultivos de soja, como o povo Kawashiva, no município de Colniza. O problema tende a ser agravado pela precariedade no atendimento à saúde indígena no estado; os Xavante, por exemplo, localizados em São Félix do Araguaia e em outros municípios vizinhos, sofrem com sérios problemas de tuberculose, leishmaniose e desnutrição, que atacam principalmente as crianças. Além dos indígenas, comunidades quilombolas, como a do distrito de Picadinhas, município de Dourados, enfrentam a resistência de produtores de soja e milho para obterem a titulação de seu território.

Além da soja, a cana-de-açúcar representa outro importante problema na Região, que se expressa, entre outros impactos, pela incorporação de diversos estabelecimentos agropecuários, fazendas e usinas na chamada 'lista suja' do trabalho escravo, criada pela portaria n. 540/2004 (Brasil, 2004) e cuja fiscalização está a cargo dos Grupos Móveis do Ministério do Trabalho e Emprego em vários estados. Vinculadas ao cultivo de cana e à produção de álcool, estão na lista fazendas do município de Poconé (MT); Iguatemi e Brasilândia (MS); Goiatuba, Jataí e Ceres (GO). Em 2008, uma fiscalização colocou em xeque a coerência do Banco Nacional de Desenvolvimento Econômico e Social (BNDES) ao encontrar várias irregularidades na Companhia Brasileira de Energia Renovável. Essa empresa, criada com a pretensão 
de se tornar uma das maiores produtoras de agrocombustíveis do mundo, tem como sócios um ex-presidente dos Estados Unidos (Bill Clinton) e um ex-presidente da Petrobras (Henri Philippe Reichstul) e atua em Goiás, Mato Grosso e Mato Grosso do Sul.

\section{Conflitos Ambientais no Sudeste: dos desertos verdes ao agrocombustível}

Conflitos importantes relacionados à expansão dos 'desertos verdes' - os monocultivos de eucaliptos e pínus, também chamadas por setores empresariais e mesmo por órgãos governamentais de 'florestas plantadas' marcam a Região Sudeste, mas também afetam estados de outras Regiões, em especial do Nordeste, como o sul da Bahia, o Pará e o Vale do Parnaíba, no Piauí e Maranhão, além de estados da Região Sul. Seja para a produção de celulose ou de carvão vegetal, os monocultivos de eucaliptos geram conflitos - principalmente na fronteira entre os estados do Espírito Santo e da Bahia, afetando tanto povos indígenas e quilombolas, como comunidades tradicionais, agricultores familiares e movimentos pela reforma agrária.

Atuando principalmente no Espírito Santo e no sul da Bahia, a Rede Alerta contra o Deserto Verde reúne vários movimentos sociais e populações atingidas, como os povos Tupinikim e Guarani, que, mesmo depois de expulsos e humilhados, ainda resistem para garantir suas terras e direitos; a Via Campesina e o Movimento das Mulheres Camponesas; e comunidades quilombolas dos municípios de São Mateus e Conceição da Barra. Entre os principais impactos socioambientais e na saúde, destacam-se a piora na qualidade de vida decorrente da perda de biodiversidade e de terras e matas necessárias para a reprodução dos modos de vida, cultura e tradições dessas populações; a contaminação por agrotóxicos; a violência contra as populações locais e a perda de fontes tradicionais de água. Também no norte de Minas Gerais, em municípios como Guaraciama e Curvelo, agricultores familiares, geraizeiros (habitantes tradicionais das Gerais ou cerrados do norte de Minas Gerais) e extrativistas, além de enfrentarem dificuldades de permanecer no local, sofrem com a perda de fontes tradicionais de água e do acesso ao Cerrado para pastagem e coleta de frutas.

O Sudeste também é também marcado por conflitos ligados à produção de agrocombustíveis, em especial o estado de São Paulo, não somente o mais industrializado e rico estado do país, mas também o maior produtor de canade-açúcar. A região em que se localizam os municípios de Ribeirão Preto, Rio das Pedras e Paranapanema e Mogi Guaçu está envolvida em denúncias 
de situações análogas ao trabalho escravo. Problemas semelhantes afetam igualmente estabelecimentos da citricultura.

Também na região do Triângulo Mineiro, os canaviais são alvo de denúncias de aliciamento de trabalhadores rurais nordestinos expostos a condições degradantes de trabalho. Tais conflitos trazem à tona as denúncias e críticas dirigidas às políticas de incentivo à produção de biocombustíveis implementadas pelo governo brasileiro. De forma distinta do discurso inicial, que afirmava ser a agricultura familiar um dos beneficiados pelo programa, os agrocombustíveis, inclusive o biodiesel, acabam por atrelar os agricultores familiares à lógica das grandes empresas, reduzindo sua autonomia.

Esse programa, que inicialmente se destinava a desenvolver a produção de mamona, acabou reorientado principalmente para a produção de óleo de soja. Com isso, a produção de agrocombustíveis foi se vinculando fortemente ao agronegócio e aos monocultivos. No caso do etanol, o programa estimula plantações de cana-de-açúcar que mantêm condições de trabalho degradantes, além de destruírem o meio ambiente, afetarem a segurança alimentar pela produção não destinada ao consumo humano e estimularem o intenso uso de agrotóxicos. Ou seja, a realidade se encontra bem distante do 'combustível verde' apresentado como alternativa de 'energia limpa' e de desenvolvimento sustentável em vários discursos oficiais e mídias. Para completar o quadro da Região Sudeste, cabe mencionar os riscos de acidentes em fábricas que produzem e armazenam agrotóxicos, importante insumo do agronegócio dos monocultivos, que são dependentes de produtos químicos. No município de Belford Roxo (RJ), em 2007 ocorreu uma explosão em um reator, ocasionando, além de quatro feridos, uma nuvem com o agrotóxico Tamaron que se espalhou pela região. Dois anos mais tarde, a Agência Nacional de Vigilância Sanitária (Anvisa) interditou cerca de um milhão de litros de agrotóxicos na fábrica com formulação adulterada. Mais emblemático, porém, foi o acidente que ocorreu em novembro de 2008 na indústria química Servatis, localizada em Resende (RJ), quando foram despejados no rio Piratininga, afluente do Paraíba do Sul, 8 mil litros do agrotóxico endossulfan, um organoclorado usado como inseticidas.

O Paraíba do Sul é o principal rio que corta o estado do Rio de Janeiro, e o acidente provocou uma grande mortandade de peixes, levando pânico a milhares de moradores dos vários municípios ao longo do rio, com a interrupção da captação de água. O acidente também afetou a vida de milhares de pescadores na região, já que a contaminação atingiu cerca de 42 espécies nativas e exóticas de peixes, tendo sido coletadas pelo menos 100 toneladas de peixes mortos nos dias que se seguiram ao acidente. 


\section{Conflitos no Sul: intensificando a resistência contra o modelo do agronegócio}

No mapa, os espaços rurais na Região Sul do país são marcados pelos conflitos relacionados à produção de eucalipto e por ações de movimentos sociais na luta contra as corporações internacionais ligadas à produção de transgênicos.

Dois eventos são emblemáticos nessa Região: a ocupação por centenas de mulheres da Via Campesina dos laboratórios e viveiros da empresa multinacional Aracruz Celulose, no município de Barra do Ribeiro (RS), com a finalidade de denunciar publicamente os malefícios dos monocultivos de eucalipto no país.

O segundo conflito se refere à luta pela desapropriação do campo experimental da empresa suíça Syngenta Seeds, destinado ao cultivo de variedades transgênicas de milho e soja, o que estaria proibido em virtude da proximidade do Parque Nacional do Iguaçu. Com várias ações entre os anos 2006 e 2007, o conflito teve seu ponto mais trágico no dia 21 de outubro de 2007, com o assassinato de Valmir Mota por seguranças armados na sede da fazenda da Syngenta, no município de Santa Tereza do Oeste (PR). No confronto, uma militante da Via Campesina perdeu a visão, e outros trabalhadores rurais ficaram feridos. O conflito, porém, resultou em uma importante vitória dos movimentos sociais, pois o centro experimental da Syngenta foi desapropriado pelo governo do Paraná e atualmente é sede do Centro Agroecológico de Experimento de Variedades Crioulas de Sementes, cuja direção está a cargo do Instituto Agronômico do Paraná, com a participação da Via Campesina.

Os conflitos fundiários no Sul também envolvem populações tradicionais. Em alguns municípios do Rio Grande do Sul, os povos Mbyá-Guarani ainda lutam por seu modo de vida e são impactados pelas fazendas de gado e as plantações de eucalipto e arroz. Na região de São Mateus do Sul, no Paraná, vivem os faxinalenses, grupo formado por 44 comunidades tradicionais camponesas, cuja formação social é caracterizada pelo uso de recursos como a terra, água e florestas. Esses faxinalenses lutam pelo reconhecimento de suas demandas, especialmente de seus territórios, e têm denunciado ameaças de grandes proprietários de terras e empresas reflorestadoras. São estas também que movem ação contra o Instituto Nacional de Colonização e Reforma Agrária (Incra) com a finalidade de anular o reconhecimento dos cerca de 8 mil hectares da comunidade quilombola de Invernada dos Negros, em Campos Novos (SC). A luta dessa comunidade tem dado maior visibilidade aos movimentos quilombolas no Sul do Brasil. 
Cidades e Injustiças Ambientais: desigualdades e a formação histórica das zonas de sacrifício

Os conflitos ambientais apresentados no mapa referentes aos espaços urbanos refletem as desigualdades sociais e discriminações presentes na formação histórica das cidades cujas taxas de crescimento atingiram níveis extremamente elevados ao longo do século XX, principalmente na sua segunda metade. Entre 1940 e 1980, o número de cidades com mais de cem mil habitantes passa de 18 para 142, com mais de 47 milhões de pessoas vivendo nas dez regiões metropolitanas do Brasil, com especial concentração em São Paulo e no Rio de Janeiro. Sem dúvida um crescimento espetacular, se recordarmos que, em 1872, a soma das dez maiores cidades brasileiras mal passava dos oitocentos mil habitantes.

Apesar das contradições desse crescimento, ocorreram muitas melhorias de vários indicadores sociais e de saúde no país, como mostram os índices de desenvolvimento humano (IDH) e de condições de vida (ICV) produzidos nas últimas três décadas e presentes em documentos divulgados pelas instituições envolvidas em sua geração - Programa das Nações Unidas para o Desenvolvimento (Pnud), Instituto de Pesquisa Econômica Aplicada (Ipea), IBGE e Fundação João Pinheiro.

Ambos os indicadores agregam dimensões de longevidade, renda e educação das populações de municípios, regiões e países, porém o ICV incorporou outros indicadores destinados a avaliar as dimensões como habitação e infância, contribuindo para melhor avaliar as desigualdades entre municípios e Regiões do Brasil. Entre 1970 e 2000, tanto o país quanto todas as macrorregiões e estados brasileiros apresentaram sensíveis melhorias nesses indicadores.

Sobre a contribuição dos vários componentes do IDH no Brasil, podemos destacar o aumento do Produto Interno Bruto (PIB) na década de 1970, da longevidade na década de 1980 e da educação na década de 1990. Essa evolução, contudo, é diferenciada, já que a educação e a longevidade foram fatores bem mais importantes do que a renda per capita nos estados mais pobres, fato parcialmente revertido ao longo dos anos 2000.

Apesar disso, as desigualdades continuam como um forte componente estrutural da sociedade brasileira e suas cidades. Isso pode ser verificado pela intensa presença das desigualdades de renda per capita no conjunto dos municípios do país, pois o componente intramunicipal é muito mais significativo do que as desigualdades entre municípios de um mesmo estado 
ou das desigualdades entre Regiões, conforme pode ser visto no Atlas do Desenvolvimento Humano no Brasil, produzido pelo Pnud (2003).

Ronaldo Herrlein Júnior (2013) também corrobora a continuidade das desigualdades no Brasil ao analisar a evolução dos IDHs na América Latina. Para incorporar o efeito da desigualdade no IDH, o Pnud desenvolveu o conceito de IDH corrigido pela desigualdade (IDH-D), já que o IDH global expressa os valores médios das variáveis que o compõem, sem levar em conta o quão desigual é o acesso à renda, educação e saúde em um país. Assim, quanto maior a desigualdade, maior a redução do IDH-D em relação ao IDH, o que não ocorreria se não houvesse desigualdade. Na América Latina, essa redução é marcante e no caso brasileiro o IDH, em 2011, foi 0,72, ocupando a sexagésima posição no ranking mundial. Mas quando é corrigido para o IDH-D, o Brasil cai para 0,52 e a $73^{\underline{a}}$ posição.

Portanto, a melhoria de alguns indicadores sociais nos últimos anos, que incluem, além da renda, as variáveis relacionadas ao aumento de domicílios ligados à rede de água e esgotos, representa mais uma consequência do processo de urbanização, crescimento econômico e das políticas compensatórias no governo Lula e menos uma mudança estrutural mais profunda das características de exclusão que conformam a sociedade brasileira.

Como revelam alguns estudos de geografia política (Santos, 1993; Santos \& Souza, 1986), a formação de periferias urbanas nos países da América Latina e no Brasil apresenta elementos estruturais semelhantes, embora com diferenças que correspondem às características econômicas, culturais e geográficas regionais. Ao longo do século $X X$, o capitalismo dependente e incipiente dessas regiões, associado a mecanismos políticos, econômicos e culturais de concentração de renda e poder, gerou um crescimento demográfico de um enorme contingente de trabalhadores com baixa e instável remuneração. Muitas vezes, esses trabalhadores se encontravam em situação de informalidade ou mesmo sem receber qualquer rendimento, constituindo uma grande massa sem capacidade de adquirir qualquer imóvel. A esse quadro, devemos acrescentar a ausência de políticas públicas que garantissem condições dignas aos ex-escravos após a 'abolição' da escravidão no Brasil, marcando o racismo institucional no país.

Se as políticas públicas nas cidades privilegiavam as elites locais e interesses de mercado, os programas de habitação popular, por seu lado, jamais ofereceram, no período de enorme crescimento das cidades, casas populares capazes de atingir, de forma expressiva, a massa de trabalhadores 
provenientes principalmente do campo. Portanto, as ofertas populares de lotes de terreno ou casas populares acessíveis não dispunham de espaços urbanos planejados com infraestrutura adequada. A única alternativa existente para boa parte da população foi simplesmente a invasão de terrenos públicos e privados que deu origem às favelas, presentes em quase todo território nacional, frequentemente em áreas de risco e sem nenhum equipamento urbano. Tal formação explica a parcela expressiva das 'zonas de sacrifício' existentes nas cidades e refletidas nos conflitos do mapa.

Campos e cidades, com suas especificidades, convivem com injustiças e dilemas que se interconectam na disputa por recursos e visões de desenvolvimento. Enquanto nos campos a força da natureza e a identidade cultural de populações tradicionais e camponesas compõem o lastro de resistência para o enfrentamento do agronegócio e dos monocultivos, nas cidades a disputa é pelos direitos fundamentais de cidadania em contextos socioambientais e políticos de grande vulnerabilidade diante do poder econômico de setores que, agora, passam a disputar os territórios onde vivem, trabalham e circulam as classes populares, cada vez empurrando-as mais para as periferias degradadas, à medida que a explosão imobiliária se expande.

Nas cidades e suas periferias, o que parece ser uma ocupação espontânea e ilegal das áreas favelizadas ou sem equipamentos urbanos é expressão intrínseca do próprio modelo de sociedade e de desenvolvimento capitalista no Brasil: o formal e informal, o legal e o ilegal ou marginal fazem parte de um sistema que ignora interesses das camadas populares e favorece os interesses de elites próximas dos núcleos do poder que definem os processos decisórios nos níveis mais elevados de governo. Em inúmeros conflitos, tais interesses se concretizam por setores cada vez mais globalizados envolvidos na especulação imobiliária, nos grandes eventos, nas indústrias 'sujas' que buscam se instalar em zonas de sacrifício, ou ainda nos resorts turísticos que cercam os territórios paradisíacos para o consumo de turistas abastados.

Os movimentos sociais encontram nas limitações do mundo material parte dos elementos que justificam a luta política; mas as elites também descobrem nessas mesmas limitações as condições para práticas populistas e clientelistas nas democracias representativas construídas em sociedades de exclusão, como a brasileira. Em decorrência da inexistência de processos mais abrangentes de enfrentamento da exclusão social e do racismo, de modo a garantir a todos o acesso aos direitos fundamentais de cidadania, qualquer processo de 'modernização' e saneamento de áreas carentes pode se transformar rapidamente em clientelismo político e, a médio prazo, em 
expulsão das massas excluídas em razão do aumento dos gastos necessários para se manter um domicílio em área saneada e com tributos a pagar.

Essa lógica perversa contribui para a reprodução de novas áreas favelizadas nas cidades, ou mesmo de periferias dentro das áreas em processo de urbanização. Portanto, entender e enfrentar conflitos ambientais urbanos é uma tarefa complexa e que envolve, necessariamente, o desafio da construção de identidades urbanas que se fortaleçam para se contrapor às forças de mercado e à cooptação clientelista.

\section{Os Conflitos Ambientais nos Espaços Urbanos}

Enquanto nos espaços rurais destaca-se a disputa por terras e recursos naturais, com a consequente degradação dos ecossistemas, nos espaços urbanos os conflitos ambientais são marcados pela formação das periferias que concentram vários riscos ambientais, seja pela falta de saneamento básico, pela proximidade de indústrias perigosas e lixões, ou ainda pela ocupação em áreas de risco em encostas perigosas ou áreas de inundação. Além disso, se a disputa por terra para plantar e por recursos da natureza (hídricos e minerais, por exemplo) conforma muitos dos conflitos ambientais no campo, nas cidades o confronto entre a especulação imobiliária e o direito à moradia das camadas mais populares é de grande relevância, conforme foi destacado nas discussões durante o Seminário Direito à Moradia e Justiça Ambiental, organizado pelo Instituto Brasileiro de Análises Sociais e Econômicas (Ibase), pela RBJA e pela Frente Estadual contra a Remoção de Favelas e pela Moradia Digna (RBJA, 2007).

Um dos motivos impulsionadores para a realização do seminário foi a campanha travada pela mídia, em especial as Organizações Globo, denominada "Ilegal, e daí?", que, ao culpabilizar pobres e moradores das favelas pela degradação ambiental no Rio de Janeiro, funcionou como estratégia de manipulação da preocupação ambiental voltada para o favorecimento dos interesses do mercado e da especulação imobiliária. Desde então, houve, de certa forma, uma intensificação desse processo com a realização de grandes eventos como a iminente realização da Copa do Mundo e das Olimpíadas, que internacionalizam a força do grande capital comercial, financeiro e imobiliário nas disputas urbanas das cidades brasileiras. $\mathrm{O}$ fenômeno das remoções e das resistências das populações e movimentos sociais urbanos, importante na formação das cidades brasileiras, já havia sido vivenciado no Rio de Janeiro durante a construção da Vila dos Jogos Pan-Americanos nos anos 2006/2007, que afetou principalmente a Comunidade do Anil. 
Nas próximas seções, abordaremos alguns dos conflitos ambientais de várias cidades do país, de acordo com os tipos de conflitos que mais se destacam no mapa.

\section{Casos de Poluição Industrial e Proximidade de Indústrias Perigosas}

De forma semelhante aos movimentos por justiça ambiental nos Estados Unidos a partir dos anos 1970, a causa mais importante de conflitos ambientais urbanos está associada aos efeitos de indústrias perigosas e poluentes, que afetam principalmente trabalhadores e camadas populares que vivem nas 'zonas de sacrifício', onde se localizam tais indústrias.

Embora a maioria dos casos esteja presente justamente nas regiões com histórico de industrialização mais importante, como as cidades do Sudeste, esse problema tende a se alastrar por todo o Brasil. São inúmeras as áreas urbanas onde indústrias químicas, petroquímicas e siderúrgicas, por exemplo, se estabelecem frequentemente por meio de processos de licenciamento ambiental que, em virtude de lacunas ou condicionalidades que nunca se realizam, permitem a sua instalação em áreas já densamente povoadas. Ou, então, junto com as indústrias surgem novos equipamentos urbanos, sistemas de transporte e facilidade de acesso a empregos, favorecendo novas ocupações informais diante da falta de planejamento e de políticas habitacionais para as classes populares.

O estado de São Paulo, por ser o mais industrializado, tem um grande histórico de conflitos desse tipo. O polo petroquímico de Mauá opera em área urbana densamente habitada, emitindo gases que, segundo denúncias, podem provocar diversos problemas de saúde, como alterações no funcionamento da tireoide, afetando particularmente as crianças. Na mesma cidade, uma fábrica produtora de nitrocelulose, ácido fluorídrico e fluoreto de alumínio tem provocado acidentes de trabalho e ambientais desde 1935, gerando diversas preocupações em trabalhadores e moradores da região.

Um dos casos mais importantes de poluição e contaminação decorrente de atividades industriais no país é o da exposição à contaminação resultante das atividades do complexo químico industrial de Cubatão, São Paulo. A população da Baixada Santista ainda hoje sofre com os efeitos do lixo tóxico clandestinamente espalhado na região pela então multinacional francesa Rhodia, fabricante de agrotóxicos entre as décadas de 1970 e 1980, e, posteriormente, fechada pelo Ministério Público no início dos anos 1990. Os organoclorados presentes no processo produtivo e espalhados pela região produzem inúmeros problemas de saúde, afetando os sistemas 
neurológico, endócrino, reprodutivo, cardiovascular, respiratório e podendo provocar câncer, entre outros efeitos. Um dos resultados dos movimentos de resistência desenvolvidos por trabalhadores e pela população local foi a criação da Associação de Combate aos Pops (ACPO), ${ }^{4}$ atualmente denominada de Associação de Combate aos Poluentes, uma das organizações não governamentais (ONGs) mais atuantes no campo da segurança química na América Latina.

Outro conflito registrado no mapa relacionado a essa questão envolve a atuação em rede de entidades baianas e paulistas no impedimento da transferência do lixo tóxico de São Paulo para o incinerador do polo industrial de Camaçari, na Bahia. Após cerca de dez anos de indefinição sobre o destino do solo contaminado recolhido por autoridades em São Paulo, a Rhodia tentou resolver o problema enviando material contaminado para ser incinerado pela empresa Cetrel, na Região Metropolitana de Salvador. Com a denúncia feita pela $\mathrm{ACPO}$ na RBJA, entidades baianas, a Assembleia Legislativa do estado e o Ministério Público atuaram na campanha contra a transferência do passivo ambiental tóxico de São Paulo para a Bahia e conseguiram impedir a chegada dos caminhões com lixo tóxico. Esse caso histórico de luta por justiça ambiental transforma a visão utilitarista dos chamados NIMBYs (sigla do inglês not in my backyard, ou "não no meu quintal"), que busca interpretar os movimentos de resistência de populações locais contra instalação de empreendimentos perigosos. No caso em foco, foi um movimento solidário que fez com que entidades paulistas e baianas se unissem em torno da defesa da vida, e não da resolução específica da destinação do lixo tóxico para fora do estado de São Paulo, cuja legislação contra a incineração de certos materiais perigosos, na época, era estadual, e não nacional, o que permitiria, não fosse a campanha, um movimento de 'exportação de riscos' entre estados do Brasil.

Outro caso bastante emblemático diz respeito à instalação do complexo siderúrgico na baía de Sepetiba, bairro de Santa Cruz, na Zona Oeste do município do Rio de Janeiro. Esse caso, abordado de forma aprofundada no capítulo 5, é curioso porque, assim como o envolvendo São Paulo e Bahia, une uma vitória por justiça ambiental a uma situação trágica. Porém, o movimento é o reverso: após uma tentativa frustrada de criação de um grande complexo siderúrgico em São Luís do Maranhão, a fábrica da multinacional ThyssenKrupp acabou sendo instalada no Rio de Janeiro. Um aspecto importante para a mudança parece ter ocorrido porque a atuação

\footnotetext{
${ }^{4}$ Para mais informações, ver: <www.acpo.org.br >.
} 
do movimento de resistência denominado Reage São Luís conseguiu reduzir a área inicialmente prevista de quatro indústrias para apenas uma na região.

A baía de Sepetiba passava por processo de busca por recuperação depois de várias tragédias ambientais provocadas por outras indústrias, como a falida Ingá Mercantil, fechada na década de 1990 após poluir a região durante anos com metais pesados. Contudo, a população local e os cerca de oito mil pescadores da região foram pegos de surpresa com o novo empreendimento, cujos impactos começaram durante a sua construção e se agravaram com o início da operação dos altos-fornos em meados de 2010, gerando problemas respiratórios decorrentes da poluição atmosférica proveniente da fábrica.

De forma similar, outros grandes empreendimentos industriais no país revelam uma lógica em que a velocidade dos processos de licenciamento supera em muito a capacidade de compreender, prevenir ou mesmo remediar os impactos sociais, ambientais e os problemas de saúde das populações. A rapidez e a busca incessante de desobstruir os 'entraves' dos investimentos são justificados em nome do 'crescimentismo' econômico e de uma oferta de empregos nem sempre concretizada, principalmente se levarmos em consideração a sua qualidade, na medida em que, muitas vezes, os trabalhadores mais qualificados acabam vindo de outros territórios, que, de fato, não são os mais impactados pelos empreendimentos.

Os complexos industriais em construção nos estados do Rio de Janeiro (como o polo petroquímico do Comperj, em Itaboraí, e o porto do Açu, no Norte Fluminense) e no Ceará (siderúrgica e termelétricas no complexo industrial e portuário de Pecém, expulsando as comunidades indígenas Anacé) são exemplos marcantes registrados no Mapa de Conflitos, que se somam aos locais onde os complexos industriais já existem e produzem inúmeros impactos sobre a saúde dos trabalhadores e moradores das regiões afetadas. O modelo de desenvolvimento hegemônico no país, que também depende de uma ágil 'indústria de licenciamento', tende a se espalhar nas diversas regiões brasileiras e impulsiona uma crescente resistência popular contra lógicas de licenciamento que não consideram adequadamente os direitos e a saúde das populações, tal como ocorre na comunidade de Paul em Vila Velha (ES), que luta contra a ameaça de instalação de um terminal de recebimento e estocagem de soda cáustica.

A poluição industrial também está presente em municípios de pequeno e médio portes em áreas do Nordeste brasileiro. O caso da empresa Cipatex ilustra o problema: a comunidade de Manguinhos, no município de Bayeux $(\mathrm{RN})$, vive em área de manguezal e resquícios de Mata Atlântica. Denúncias 
da comunidade relatam que rejeitos tóxicos provenientes da fábrica têm sido lançados sem tratamento no rio, tornando perigoso o consumo de peixes na região.

Outro caso emblemático no mapa e com conotações de conflito urbano, embora possa ocorrer nas mais distantes construções rurais, diz respeito ao problema do amianto. Substância mineral considerada extremamente perigosa em virtude do risco de provocar câncer nas populações expostas, o amianto já foi banido em diversos países, mas continua a ser produzido e comercializado no Brasil, em decorrência do forte lobby da indústria. No mapa, os conflitos se alastram por Goiás, estado em que uma mina ainda funciona, Rio Grande do Norte, Bahia e São Paulo. Mas a realidade é que a epidemia invisível do amianto tende a se alastrar por todo o país, colocando em risco a saúde de homens e mulheres, sejam trabalhadores das minas, fábricas, construção civil ou aqueles que manipulam o amianto ou vivem em áreas em que se produz essa fibra mineral, incluindo-se locais contaminados pelo lixo tóxico oriundos da demolição de antigas construções. ${ }^{5}$

Embora haja um forte movimento nacional pelo banimento do amianto no país, com legislações específicas em alguns estados e municípios nessa direção, o movimento ainda não obteve uma proibição total por causa de um Estado que assume posições ambíguas diante do problema. Impulsionada principalmente por associações de vítimas em vários locais do país, a luta continua com avanços e retrocessos, enquanto novos casos de doenças e mortes, muitos invisíveis em virtude das deficiências do sistema de saúde, continuam a ocorrer.

O problema do ciclo da mineração e aproveitamento do urânio no Brasil gera inúmeros casos de conflitos espalhados pelo país. Há uma área desativada de mineração de urânio em Poço de Caldas (MG), com elevado passivo ambiental ainda desconhecido; uma situação atual de mineração no município de Caetité, cuja população ao redor, com o apoio de ambientalistas, da igreja local, da Associação Movimento Paulo Jackson e do Ministério Público, mobilizam-se para protestar contra a falta de informações e as suspeitas de contaminação das águas e solos da região; e uma futura mineração consorciada de urânio e fosfato (este para a produção de fertilizantes) no município de Santa Quitéria (CE), inicialmente prevista para entrar em operação em 2012. As Indústrias Nucleares do Brasil (INB) esperam que o processo de licenciamento ambiental da mina no Ceará

\footnotetext{
${ }^{5}$ Para mais informações, ver o portal da Associação Brasileira dos Expostos ao Amianto (Abrea): $<w w w . a b r e a . c o m . b r>$.
} 
seja encerrado em 2014, mas diversas organizações de justiças ambiental e ambientalistas atuam para impedir que isso aconteça.

Um problema central de todos esses casos se refere à relação das mineradoras com os órgãos reguladores e fiscalizadores, já que a empresa estatal responsável pela mineração, as INB, tem como sócio o próprio órgão regulador das atividades nucleares e radionizantes, a Comissão Nacional de Energia Nuclear (CNEN).

Além da mineração de urânio, outro caso de injustiça ambiental bastante relevante foi o acidente com o Césio 137, que, apesar de ocorrido em 1987 em Goiânia (GO), até hoje produz reações e lutas por direitos, especialmente por parte da Associação das Vítimas do Césio 137. O desastre ocorreu dois anos depois de um equipamento de radioterapia, que continha uma cápsula do Césio 137, ter sido abandonado nas antigas instalações do Instituto Goiano de Radioterapia (IGR), sem que nenhuma das instâncias envolvidas na fiscalização e destinação adequada do equipamento agisse a tempo de evitar o acidente. $\mathrm{O}$ equipamento foi achado e levado por catadores de materiais para ser revendido a um ferro-velho, sendo desmontado e transportado em pedaços, provocando a tragédia.

Embora mais de quinhentas pessoas já tenham sido diagnosticadas, o número de afetados ainda não é conhecido, pois o total de expostos foi muito grande, e os sintomas das doenças provocadas pela radiação são confundíveis com os de outras, manifestando-se principalmente a médio e longo prazos. As primeiras vítimas foram as que mais se contaminaram, e algumas já morreram.

A ação que seguiu a descoberta do desastre envolveu uma verdadeira operação de guerra: cerca de 113 mil pessoas foram monitoradas em um estádio de futebol. Dessas, aproximadamente 250 sofreram significativa contaminação interna ou externa, e metade desse grupo foi submetida a acompanhamento e tratamento ambulatorial e acometida por problemas de saúde tais como síndrome aguda da radiação, falência de medula óssea, amputação de membros e síndrome cutânea da radiação, entre outras complicações recorrentes. Desde então, a população atingida, vítima de estigmatização e de falta de assistência médica e social, vem lutando por seus direitos por intermédio da Associação das Vítimas do Césio 137. Apesar de inúmeras vitórias, ainda persistem, segundo a associação, o descaso e a falta de reconhecimento das populações afetadas, até mesmo por parte do meio acadêmico, cujos estudiosos, em suas pesquisas, frequentemente deixam de ouvir as reivindicações das populações atingidas. 


\section{Áreas Contaminadas e Lixões}

O desenvolvimento industrial e urbano nas últimas décadas, de natureza iníqua e insustentável, também está gerando um problema que tende a se agravar. Ele diz respeito aos passivos ambientais presentes em áreas contaminadas por lixo industrial tóxico, ou pelo próprio lixo urbano produzido nas cidades, muitas vezes depositado de forma clandestina e sem conhecimento das autoridades ambientais e sanitárias. Com relação aos passivos ambientais com lixos industriais tóxicos, além do mencionado caso da Baixada Santista, alguns dos conflitos urbanos do mapa revelam situações emblemáticas, como o da Cidade dos Meninos, em Duque de Caxias (RJ), cujo problema remonta a uma antiga fábrica do Ministério da Saúde, responsável pela produção de inseticidas usados em campanhas de controle de vetores no país.

Construída próximo de um abrigo de menores, a fábrica foi fechada no início da década de 1960 com milhares de toneladas de resíduos tóxicos que permaneceram no local. Moradores da região passaram a conviver com o lixo tóxico, alguns ainda o usavam como inseticida, e somente no final da década de 1980 o problema foi tornado público mediante várias ações do Ministério Público e órgãos de governo, até mesmo do réu, o próprio Ministério da Saúde. Contudo, longe de se tornar uma ação exemplar de remediação ambiental e reparação social, até hoje o caso se alastra na burocracia da Justiça e dos órgãos envolvidos sem uma solução definitiva.

Outro caso importante é o da empresa Shell, cuja unidade de armazenamento foi responsável pela contaminação do subsolo e das águas subterrâneas da Vila Carioca, localizada na Zona Sul da cidade de São Paulo. A contaminação inclui agrotóxicos e metais pesados em altas concentrações que, segundo denúncias, ameaçam a saúde de até trinta mil pessoas num raio de $1 \mathrm{~km}$. Considerada uma das maiores contaminações ambientais da cidade, foi objeto de ação civil pública em que figuram como rés a Shell e a Companhia de Tecnologia de Saneamento Ambiental (Cetesb) - atual Companhia Ambiental do Estado de São Paulo -, agência ambiental do governo paulista.

Além desse caso, a mesma multinacional está envolvida em outra grave contaminação ambiental no Recanto dos Pássaros, em Paulínia (SP). Relatórios indicam ser a cidade a quinta mais contaminada do mundo, e trabalhadores e moradores ainda sofrem com o passivo socioambiental deixado pela empresa. A fábrica de agrotóxicos na cidade funcionou entre 1975 e 1993, e durante esse período a Shell Química contaminou o lençol freático nas proximidades do rio 
Atibaia, um importante manancial da região, com os organoclorados aldrin, endrin e dieldrin. Os dados sobre a saúde dos moradores e trabalhadores são impressionantes: em 2001, avaliações na população indicaram que 156 pessoas $-86 \%$ dos moradores do bairro - apresentavam pelo menos um tipo de resíduo tóxico no organismo. Desses, 88 apresentaram intoxicação crônica, 59 tinham tumores hepáticos e da tireoide, e 72 estavam contaminados por drins. Segundo o Sindicato Químicos Unificados e a Associação dos Trabalhadores Expostos a Substâncias Químicas (Atesq), até o final de 2009 já haviam morrido 51 ex-trabalhadores da Shell. Em abril de 2013, as multinacionais Shell e Basf assinaram acordo se comprometendo a pagar uma indenização de aproximadamente $\mathrm{R} \$ 370$ milhões para atendimento médico a mais de mil ex-trabalhadores (Repórter Brasil, 2013).

Ainda no estado de São Paulo, cabe destacar o problema da contaminação do solo provocada por postos de combustíveis. Esse tipo de empreendimento está próximo dos núcleos urbanos, expondo as pessoas aos riscos de intoxicação, já que a gasolina, o diesel e outros derivados de petróleo são explosivos e tóxicos, podendo se acumular na cadeia alimentar. Os postos também produzem a contaminação por metais pesados, como o chumbo, o cromo e o cádmio. O problema, contudo, não é específico do estado de São Paulo, embora haja uma maior visibilidade de seus casos em razão da existência de um relatório anual de áreas contaminadas produzido pela Cetesb. O relatório de 2010 indica 3.675 áreas contaminadas em São Paulo, das quais $79 \%$ (2.922) dizem respeito a contaminações causadas por postos de combustíveis (Cetesb, 2010).

No Brasil, existem aproximadamente 35 mil postos de combustíveis, a maioria construída durante a década de 1970. Com uma média de vida útil de 25 anos para tanques subterrâneos, supomos que muitos deles já estejam comprometidos e representem uma grande fonte de contaminação nos locais em que estão localizados, ainda que o diagnóstico da contaminação não tenha sido realizado. Além disso, muitos funcionam de forma irregular e sem licenciamento ambiental. Mesmo no estado de São Paulo, com a existência do maior órgão ambiental do país, há denúncias no mapa, datadas de junho de 2009, de que quase cinco mil postos, dos nove mil existentes, funcionavam sem licença da Cetesb, e que 3,6 mil estariam em processo de regularização.

O lixo industrial depositado de forma clandestina em terrenos que serviram posteriormente para a construção de moradias representa outra tragédia para a saúde pública de inúmeros brasileiros. Na Grande São Paulo, é bastante conhecido o caso do condomínio residencial Barão de Mauá, construído no Parque São Vicente, em terreno de propriedade da Companhia 
Fabricadora de Peças (Cofap), que foi usado por vinte anos como lixão industrial. A Cetesb participou da aprovação da construção do condomínio em 1994, apesar de ter aplicado multas durante vinte anos por depósito de lixo tóxico no local. O subsolo e as águas subterrâneas desse conjunto habitacional - onde vivem cerca de cinco mil pessoas - estão contaminados por substâncias tóxicas como o benzeno e diversos organoclorados, e o local é ainda afetado pela emissão de gases inflamáveis. Em 2006, uma decisão judicial definiu que as famílias deveriam ser retiradas e indenizadas, mas ainda hoje moradores e Ministério Público empreendem esforços para o cumprimento da sentença judicial.

O problema dos passivos ambientais em áreas com resíduos industriais perigosos não está localizado apenas nas regiões mais industrializadas das Regiões Sudeste e Sul. Outro caso relevante é o da contaminação por chumbo em Santo Amaro da Purificação, Bahia. Entre 1960 e 1993, a Companhia Brasileira de Chumbo (Cobrac) explorava o elemento químico na mina de Boquira, e o transformava em lingotes para a comercialização. Estimase que, no período de funcionamento, a Cobrac tenha produzido cerca de 900 mil toneladas de liga de chumbo, gerando cerca de 500 mil toneladas de escória, material com até 3\% de concentração desse elemento.

A lógica para a instalação da fábrica, desde aquela época, foi a mesma que a usada em vários empreendimentos atuais: a chegada da fábrica a Santo Amaro da Purificação foi acompanhada de promessas de progresso e emprego. Porém, segundo relatório do Instituto de Desenvolvimento Ambiental (IDA), a Usina Plumbum, sucessora da Cobrac, localizava-se em área pouco favorável do ponto de vista ambiental, situada a noroeste da zona urbana de Santo Amaro, no Recôncavo Baiano, a 300 metros da margem do rio Subaé, que recebia os efluentes líquidos sem nenhum tratamento. Ao longo das três décadas em que operou no município, a fábrica da Cobrac despejou na atmosfera, em cursos d'água e no solo diversos resíduos e escórias de chumbo e cádmio.

Um dos fatos mais incríveis relacionado ao caso é o relato de que parte considerável desses resíduos foi doada à prefeitura local e à população como componente para argamassa a ser utilizada na reforma e construção de casas e escolas, de poços artesianos e na pavimentação de ruas e de praças, bem como pátios escolares, ampliando, assim, as vias de exposição e contaminação ambiental. Essa contaminação também se deu por contato com feltros utilizados como filtros das chaminés da usina. O material era recolhido por funcionários da empresa e moradores de Santo Amaro, que depois o reutilizavam como tapetes, colchões e brinquedos para as crianças. 
Trata-se de um enorme passivo ambiental, e a ação governamental tem sido marcada por um caráter dúbio na localidade. Ao mesmo tempo que institui comissões e que fornece cestas básicas para amenizar a fome, o governo nega acesso dos trabalhadores a benefícios previdenciários, em razão da recusa do Instituto Nacional da Seguridade Social (INSS) em reconhecer as doenças decorrentes da contaminação.

O uso de material contaminado em ruas e casas também ocorre em outras realidades, como no município de Joinville (SC), onde ambientalistas, o Ministério Público Federal e outras entidades criticam a utilização de areia contaminada na construção de peças de concreto e asfalto empregados em vias públicas, colocando a sociedade civil em conflito com o governo de Santa Catarina, a Federação das Indústrias do Estado de Santa Catarina (Fiesc) e a Fundição Tupy, que buscou legalizar a doação de areia utilizada nos moldes para fundição de metais. Porém, a areia é considerada tóxica pela presença potencial de substâncias como metais pesados e fenóis, e a possível aprovação pelos órgãos ambientais é motivo de disputa no estado de Santa Catarina.

O problema envolvendo moradores no entorno de lixões representa outra clássica situação de injustiça ambiental urbana que se espalha por todo o país. Nos últimos anos, diversos desses lixões estão passando por um processo de desativação ou transformação em aterros controlados ou sanitários, teoricamente de menor impacto ambiental e sem a presença de crianças e adultos trabalhando ou circulando em ambientes de elevada insalubridade ocasionada pelo contato direto com o lixo bruto, sem processo. Contudo, inúmeros municípios e localidades ainda enfrentam o problema, e até mesmo a instalação de novos aterros encontra forte resistência da população, que não confia nas autoridades e técnicos quando prometem que os futuros aterros não gerarão impactos ambientais, sociais e sanitários negativos.

No mapa, o problema aparece em vários casos. No Rio de Janeiro, encontramos o aterro metropolitano de Jardim Gramacho, em Duque de Caxias. Sua instalação, em 1976, atendendo a vários municípios do Grande Rio, ocorreu em um contexto sociopolítico em que a questão ambiental ainda era incipiente, e uma série de erros estruturais gerou riscos ambientais para a população local e ameaçou o ecossistema da baía de Guanabara.

O primeiro desses erros foi a própria escolha do local: ocupando mais de 1,3 milhões de $\mathrm{m}^{2}$, o lixão foi instalado em área de aterro onde outrora existia um manguezal, e sua presença, apesar de desativado, ainda hoje ameaça a baía com o despejo de toneladas de lixo e chorume. Entretanto, como uma parte significativa das 8 mil toneladas de lixo levadas ao local até 
a data de sua desativação (junho de 2012) era de materiais recicláveis, essa localidade passou a movimentar toda uma economia da reciclagem: das cerca de vinte mil pessoas que moravam nos arredores do lixão, estima-se que aproxidamente $3 / 4$ dependiam direta ou indiretamente desse comércio. Eram cerca de cinco mil catadores (cooperativados e autônomos), donos e funcionários dos cerca de quarenta depósitos de material reciclável existentes no bairro, além de comerciantes, oficinas mecânicas, borracharias e fábricas de beneficiamento desse material.

O anúncio do fechamento do aterro em 2011, portanto, gerou grande apreensão na população local, e entidades representativas dos catadores locais buscaram soluções para o problema. Organizados em torno da Associação dos Catadores do Aterro Metropolitano de Jardim Gramacho (ACAMJG) e articulados com o Movimento Nacional dos Catadores de Material Reciclável (MNCR), os catadores de Jardim Gramacho lutaram pelo reconhecimento de sua atividade como profissão e do seu importante papel social como agentes de preservação ambiental, assim como pela constituição de uma política de coleta seletiva gerida pelas cooperativas de catadores no município. Algumas propostas foram negociadas com a prefeitura local, e chegou-se a definir um local para a construção de um polo de reciclagem de material reciclável. Contudo, o projeto tem encontrado obstáculos, e várias indefinições preocupavam os catadores. Um deles, segundo a ACAMJG, é a dificuldade do município e do estado do Rio de Janeiro de cumprirem as metas previstas de um incremento anual de $5 \%$ dos resíduos destinados para reciclagem, chegando a 25\% em 2016.

Ainda no Rio de Janeiro, outros conflitos associados ao de Jardim Gramacho são interessantes para pensarmos o caminho do lixo e seus problemas na conformação das 'zonas de sacrifício'. Uma primeira tentativa de se instalar um aterro para substituir Jardim Gramacho se deu no bairro de Paciência, município do Rio de Janeiro. Entretanto, uma série de irregularidades no processo licitatório e as críticas de moradores, ambientalistas, do Ministério Público, do Tribunal de Contas da União (TCU) e da Aeronáutica acabaram impossibilitando que o projeto fosse levado adiante. Logo depois, anunciouse a instalação do aterro sanitário no município de Seropédica, na Baixada Fluminense, que tem gerado protestos de inúmeras entidades da região.

Segundo Adriano Dias, membro da ONG ComCausa,

a Baixada tem que deixar de ser considerada 'zona de sacrifício', não é à toa que aqui temos três dos piores crimes ambientais do país [o depósito de lixo industrial Centres, em Queimados; a Cidade dos Meninos, em Duque de Caxias; e a contaminação da empresa Ingá na Baía de Sepetiba, Itaguaí]. Mas os tempos são 
outros, exigimos informações detalhadas. Nós da Baixada não aceitaremos mais que os ditos empreendimentos sejam impostos sem discussão com os moradores da região. (Fiocruz/Fase, 2010)

Essa fala expressa, de forma vívida, a maneira como a discriminação e as desigualdades sociais se mesclam com o lixo urbano na produção de injustiças sociais, presentes no mapa principalmente nos estados das Regiões Sudeste e Nordeste, onde as populações são vítimas das formas discriminatórias da destinação dos resíduos das cidades.

\section{Para Completar o Quadro Urbano: desastres, falta de saneamento, especulação imobiliária e racismo ambiental}

Os ambientes urbanos, com elevadas densidades populacionais, concentram inúmeros riscos de desastres, mas a mescla entre desigualdade e discriminação radicaliza a produção de desastres de várias ordens, que tendem a atingir as populações mais vulneráveis por serem discriminadas e pobres. Embora nos últimos anos não tenham ocorrido catástrofes industriais com um elevado número de mortes simultâneas, como a ocorrida na Vila Socó, Cubatão, em 1984, o Mapa de Conflitos apresenta vários casos que revelam a trágica combinação entre riscos tecnológicos ambientais e populações urbanas discriminadas.

No Rio Grande do Norte, o rompimento da barragem de Camará, por falha na construção em obra superfaturada, em julho de 2004, gerou uma calamidade cujos efeitos ainda hoje são sentidos pelos moradores dos territórios atingidos, em especial os municípios de Alagoa Nova, Areia e os sítios urbanos das cidades de Alagoa Grande e Mulungu, onde as consequências do desastre foram mais graves. O cenário foi semelhante ao de uma guerra, com destruição de casas, ruas cobertas de lama, sítios com animais mortos, plantações arrancadas e economias perdidas, resultado da catástrofe anunciada por uma política de gestão de recursos hídricos sem maiores cuidados com as populações afetadas no entorno da barragem.

Também no Sudeste, outra barragem se rompeu, mas desta vez contendo os rejeitos da Rio Pomba Mineração, localizada em Miraí, na Zona da Mata mineira. O rompimento fez com que 2 milhões de metros cúbicos de lama alagassem várzeas e residências da região, com sessenta pessoas desabrigadas, 765 desalojadas e, pelo menos, duas mil pessoas afetadas pelo vazamento e 35 casas destruídas. Mas esse caso, infelizmente, não é isolado: 0 relatório anual da Fundação Estadual do Meio Ambiente - Feam - (Fiocruz/ Fase, 2010), referente a 2007, evidencia que 58 barragens de rejeitos em 
Minas Gerais, ou cerca de 10\% das 606 do estado, estão 'instáveis', ou seja, inadequadas do ponto de vista da segurança ambiental.

Geralmente, as barragens de rejeitos pertencem a grandes empresas, que movimentam produtos tóxicos em seus processos produtivos. Acidentes anteriores, como o ocorrido no mesmo rio Pomba em 2003, quando um vazamento de resíduos tóxicos da Indústria Cataguazes de Papel atingiu inúmeras cidades à margem do rio Paraíba do Sul afetando milhões de pessoas, acontecem de forma similar ao acidente ocorrido na cidade de Resende, no Rio de Janeiro, com o vazamento do agrotóxico endossulfan, já relatado aqui. Todos esses casos comprovam os riscos de atividades industriais para a sustentabilidade hídrica a jusante das bacias hidrográficas onde essas empresas se encontram.

Outro problema que tende a se agravar se refere aos desastres decorrentes de chuvas torrenciais, que afetam principalmente populações urbanas pobres em áreas vulneráveis, como encostas e favelas da periferia. Esse problema, que não é novo, parece se alastrar mais pelo país, na medida em que as instabilidades provocadas pelas mudanças climáticas globais podem afetar fenômenos climáticos extremos, como as chuvas torrenciais, constituindose, portanto, em uma questão de justiça climática. Mas esse problema está diretamente relacionado às dificuldades de acesso à moradia e ao saneamento básico por parte das camadas populares.

Conforme já discutido anteriormente e reforçado por teóricos que tratam da exclusão urbana, como Raquel Rolnik (2008), ao delimitarmos as fronteiras que separam os espaços regulares/formais dos irregulares/ informais, o modelo de exclusão territorial que define a cidade, funciona como uma espécie de engrenagem de uma máquina de crescimento que, ao produzir cidades, reproduz desigualdades. Atualmente, as relações entre Estado e capital imobiliário e financeiro influenciam fortemente os processos de valorização e de desvalorização urbana por meio da formação das novas centralidades e dos eixos de expansão urbana, fazendo com que lógicas de mercado se sobreponham ao direito à moradia, com a hegemonia dos setores dominantes sendo reforçada pela criminalização dos movimentos sociais que lutam por direitos fundamentais nas periferias.

Esse é justamente o caso do conflito intitulado "População da periferia de São Paulo sofre com o descompromisso de políticas públicas e administração voltada para a exclusão", que alerta sobre os conflitos urbanos que, há décadas, envolvem ações de remoção violenta e compulsória de populações pobres dos seus territórios. As razões para isso envolvem desde lógicas de mercado, 
projetos imobiliários até argumentos de preservação ambiental em áreas que passam a ser valorizadas para outros usos, com os excluídos constituindose em uma população vulnerável, condicionada pela precariedade tanto urbanística quanto fundiária. São inúmeros os casos na Grande São Paulo que envolvem remoções para o desenvolvimento de projetos urbanos que atendem às populações mais abastadas, ao mesmo tempo que criminalizam e expulsam para novas periferias os moradores excluídos.

No Mapa de Conflitos, a questão da falta de saneamento básico ainda não se expressa de forma marcante, embora a maioria da população mais pobre sofra com o problema, principalmente os moradores das favelas e periferias. Isso revela a forma como os movimentos por justiça ambiental nas cidades ainda podem crescer com esta agenda. Um caso interessante expresso no mapa é o de Macapá, no estado de Amapá, semelhante a inúmeras cidades brasileiras. A falta de saneamento básico afeta cerca de $60 \%$ da população amapaense, e a falta de água tratada em Macapá tem contribuído para a proliferação de doenças relacionadas à ingestão de água contaminada, a exemplo da hepatite, cólera, diarreia e da própria dengue.

Além da falta de água potável em muitos bairros, a falta de saneamento básico se soma a soluções improvisadas para captação de água e despejo de esgoto, geralmente no próprio rio (de onde parte da população local retira a água que consome) e na orla de Macapá. Para piorar, os macapaenses sofrem as precárias condições dos serviços públicos de atendimento médico-hospitalar, visto que, à época do levantamento (novembro de 2009), funcionava apenas um pronto-socorro 24 horas/dia para atender a uma população de 344 mil pessoas. Segundo levantamento da Companhia de Água e Esgoto do Amapá (Caesa), quatro de cada dez pessoas não têm acesso à água potável e apenas quatro de cada cem pessoas têm acesso à rede de esgoto, situação ainda mais grave nos bairros da periferia.

A discriminação gerada pela desigualdade social se mescla com o racismo ambiental nos ambientes urbanos de forma mais nítida quando a especulação imobiliária, a expansão de projetos turísticos ou mesmo a racionalidade de planos diretores investem contra o direito de comunidades tradicionais e quilombolas que vivem nas cidades. Esses casos aparecem no mapa em distintas regiões e cidades, como em Getúlio Vargas, bairro de Aracaju (SE), que teve o primeiro quilombo urbano do estado e o segundo do Brasil oficialmente reconhecido em abril de 2007 - a Comunidade Quilombola Maloca. Organizadas em torno da associação civil Criança e Liberdade (Criliber), as cerca de cinquenta famílias desse quilombo continuam lutando 
contra o preconceito, a discriminação, o racismo, a violência e pela garantia da permanência da comunidade em seu território ancestral.

Em Belo Horizonte (MG), a comunidade quilombola dos Luízes, localizada em um dos bairros mais valorizados da cidade, luta para manter parte de seu território, que foi usurpado por construtoras e particulares desde 1930. Desde 2007, os membros da comunidade quilombola têm atuado politicamente com a finalidade de garantir a titulação de seu território tradicional e assegurar o usufruto dos recursos naturais e expressões culturais ainda preservados, como a festa de Nossa Senhora de Santana, demonstração maior da religiosidade da comunidade e da sua resistência, comemorada no dia 26 de julho.

Em pleno Rio de Janeiro, os cerca de trinta integrantes da família Pinto, descendentes de um casal de escravos fugidos, resistem para permanecer na ladeira Sacopã, enfrentando décadas de luta contra a especulação imobiliária e governos municipais comprometidos com o avanço das construtoras sobre uma das últimas áreas verdes preservadas no coração na Zona Sul da cidade. Nessa área, condomínios e casas de alto padrão substituíram as antigas comunidades de pescadores, favelas e refúgios de escravos ali existentes. O quilombo urbano da Sacopã continua a ser um dos poucos focos de resistência ao processo de expulsão das famílias mais pobres da Zona Sul da cidade para as encostas dos morros e as áreas periféricas. $\mathrm{O}$ resgate de suas origens, a valorização de sua cultura e o reconhecimento da comunidade como remanescente de quilombos têm sido a única estratégia eficaz contra a sua remoção, visando a garantir a titulação da área de $18 \mathrm{mil} \mathrm{m}^{2}$ que atualmente ocupam, boa parte ainda preservada como um dos últimos resquícios de Mata Atlântica da Zona Sul da cidade. 


\section{Referências}

ALENTEJANO,P.QuestãoagrárianoBrasilatual:umaabordagema partirdageografia. TerraLivre, 36: 116-142, 2011.

ALMEIDA, S. G.; PETERSEN P. \& CORDEIRO, A. Crise Socioambiental e Conversão Ecológica da Agricultura Brasileira: subsídios à formulação de diretrizes ambientais para desenvolvimento agrícola. Rio de Janeiro: Agricultura Familiar e Agroecologia, 2001.

ANDRADE, D. C. \& ROMEIRO A. R. Serviços ecossistêmicos e sua importância para o sistema econômico e o bem-estar humano. Campinas: IE, Unicamp, 2009. (Texto para discussão n. 155).

ASSIS, W. F. T. Dinâmicas territoriais e conflitos ambientais na produção de agrocombustíveis: a colonialidade na apropriação da natureza. In: ENCONTRO ANU AL D A ANPOCS, 34, 2010, São Paulo. Anais... São Paulo, 2010.

BRASIL. Ministério do Trabalho e Emprego. Portaria n. 540, de 15 de outubro de 2004. Brasília, 2004. Disponível em: <www.portal.mte.gov.br/data/files/FF8080812BE914E6012BF2B6EE2664 8F/p_20041015_540.pdf>. Acesso em: 6 abr. 2011.

BRASIL. Ministério do Desenvolvimento, Indústria e Comércio Exterior. Álcool combustível. Brasília, 2011. Disponível em: <www.desenvolvimento.gov.br/sitio/interna/interna. php?area=2\&menu=3652>. Acesso em: 18 jun. 2012.

BRIANEZI, T. Cientistas divergem sobre exata contribuição do etanol. São Paulo, 2010. Disponível em: <www.reporterbrasil.org.br/agrocombustiveis/exibe.php?id=118>. Acesso em: 12 jun. 2011.

COMPANHIA DE TECNOLOGIA DE SANEAMENTO AMBIENTAL (CETESB). Texto explicativo: relação das áreas contaminadas e reabilitadas no estado de São Paulo, 2010. Disponível em: <www.cetesb.sp.gov.br/userfiles/file/areas-contaminadas/texto_explicativo_ dez_10.pdf $\geq$. Acesso em: 13 maio 2011.

CAIADO, A. S. C. \& SANTOS, S. M. M. Fim da dicotomia rural-urbano? Um olhar sobre os processos socioespaciais. São Paulo em Perspectiva, 17 (3-4): 115-124, 2001.

CARNEIRO, F. F. et al. Saúde de famílias do Movimento dos Trabalhadores Sem Terra e de boias-frias, Brasil, 2005. Revista de Saúde Pública, 42(4): 757-763, 2008.

FUNDAÇÃO OSWALDO CRUZ/FEDERAÇÃO DE ÓRGÃOS PARA ASSISTÊNCIA SOCIAL E EDUCACIONAL (FIOCRUZ/FASE). Mapa de Conflitos Envolvendo Injustiça Ambiental e Saúde no Brasil. Rio de Janeiro: 2010. Disponível em: <www.conflitoambiental.icict.fiocruz.br>. Acesso em: 19 maio 2011.

FERREIRA, A. D. D. Processos e sentidos sociais do rural na contemporaneidade: indagações sobre algumas especificidades brasileiras. Estudos, Sociedade e Agricultura, 18: 28-46, 2002.

FOOD AND AGRICULTURE ORGANIZATION (FAO). The state of food and agriculture. FAO Agriculture Series 38, 2007. Disponível em: <ftp://ftp.fao.org/docrep/fao/010/a1200e/a1200e00. pdf>. Acesso em: 16 maio 2011.

FOOD AND AGRICULTURE ORGANIZATION (FAO)/INTERNATIONAL FERTILIZER INDUSTRY ASSOCIATION (IFA). Fertilizer Strategies. Rome, Paris: Food and Agriculture Organization, International Fertilizer Industry Association, 1999. Disponível em: <ftp://ftp.fao. org/agl/agll /ch10/ch104.pd>. Acesso em: 30 maio 2011.

GIAMPIETRO, M. The precautionary principle and ecological hazards of genetically modified organisms. Ambio, 31(6): 466-470, 2002.

HERRLEIN JÚNIOR, R. Análise da evolução dos IDHs global e parciais (saúde, educação e renda) de 2000 a 2011 e do IDH-desigualdade em 2011 para a América Latina (12 países) 
e o BRIC (Brasil, Rússia, Índia e China). In: Rodrigues, V. A. (Org.). Observatório Internacional de Capacidades Humanas, Desenvolvimento e Políticas Públicas: estudos e análises. Brasília: UnB, ObservaRH, Nesp, 2013.

HOFFMANN, R. \& NEY, M. G. Estrutura fundiária e propriedade agrícola no Brasil, grandes regiões e unidades da federação. Brasília: Ministério do Desenvolvimento Agrário, 2010.

INSTITUTO BRASILEIRO DE GEOGRAFIA E ESTATÍSTICA (IBGE). Censo Agropecuário 2006: resultados preliminares. Rio de Janeiro, 2006. Disponível em: <www.ibge.gov.br/home/ estatistica/economia/agropecuaria/censoagro/2006/>. Acesso em 30 maio 2011.

INSTITUTO BRASILEIRO DE GEOGRAFIA E ESTATÍSTICA (IBGE). Mapa de Pobreza e Desigualdade. Rio de Janeiro, 2008. Disponível em: <www.ibge.gov.br/estadosat/temas.php?s igla=rn\&tema=mapapobreza2003 $>$. Acesso em: 5 abr. 2011.

INSTITUTO BRASILEIRO DE GEOGRAFIA E ESTATÍSTICA (IBGE). Censo Agro 2006: IBGE revela retrato do Brasil agrário. Rio de Janeiro, 2009. Disponível em: <www.ibge.gov.br/home/ presidencia/noticias/noticia_visualiza.php?id_noticia $=1464 \& i d \_p a g i n a=1 \&$ titulo=Censo-Agro2006:-IBGE-revela-retrato-do-Brasil-agrario>. Acesso em: 10 maio 2011.

INSTITUTO BRASILEIRO DE GEOGRAFIA E ESTATÍSTICA (IBGE). Sinopse do Censo Demográfico 2010. Disponível em: <www.censo2010.ibge.gov.br/sinopse/index.php? dados $=4 \& u f=00>$. Acesso em: 12 junho 2012.

MEIRELLES, D. \& CALAZANS, M. $\mathrm{H}_{2} \mathrm{O}$ para Celulose $x$ Água para Todas as Línguas: o conflito ambiental no entorno da Aracruz Celulose S/A. Vitória: Fase, 2006.

PELAEZ, V.; TERRA, F. H. B. \& SILVA, L. R. A regulamentação dos agrotóxicos no Brasil: entre o poder de mercado e a defesa da saúde e do meio ambiente. Revista de Economia, 36(1): 27-48, 2010.

PIGNATI, W. A. o caso das 'chuvas' de agrotóxicos sobre a cidade de Lucas do Rio Verde-MT. In: MACHADO, P. (Org.). Um avião Contorna o Pé de Jatobá e a Nuvem de Agrotóxico Pousa na Cidade. 1. ed. Brasília: Anvisa, Ministério da Saúde, 2008.

PORTO, M. F. \& MILANEZ, B. Eixos de desenvolvimento econômico e geração de conflitos socioambientais no Brasil: desafios para a sustentabilidade e a justiça ambiental. Ciência \& Saúde Coletiva, 14: 1983-1994, 2009.

PORTO, M. F. \& SOARES, W. L. Modelo de desenvolvimento, agrotóxicos e saúde: um panorama da realidade agrícola brasileira e propostas para uma agenda de pesquisa inovadora. Revista Brasileira de Saúde Ocupacional, 37(125): 17-31, 2012.

PROGRAMA DAS NAÇÕES PARA O DESENVOLVIMENTO (PNUD). Atlas de Desenvolvimento Humano 2003. Disponível em: www.pnud.org.br/atlas. Acesso em: 19 maio 2011.

REDE BRASILEIRA DE JUSTIÇA AMBIENTAL (RBJA). Seminário Direito à Moradia e Justiça Ambiental. Rio de Janeiro, 2007. Disponível em: <www.justicaambiental.org/_justicaambiental/ pagina.php?id=1768>. Acesso em: 10 maio 2011.

REDE BRASILEIRA DE JUSTIÇA AMBIENTAL (RBJA). Site. Disponível em: <www. justicaambiental.org.br>. Acesso em: 13 maio 2011.

REPÓRTER BRASIL. Shell e Basf terão que pagar indenização milionária por contaminação em fábrica de agrotóxicos, 2013. Disponível em: <www.reporterbrasil.org.br/2013/04/shell-ebasf-terao-que-pagar-indenizacao-milionaria-por-contaminacao-em-fabrica-de-agrotoxicos>. Acesso em: 8 abr. 2013.

RIGOTTO, R. M. Exploring fragility: industrial delocalization, occupational and environmental risks, and non-governmental organizations. International Journal of Environmental Research and Public Health, 6: 980-998, 2009. 
ROLNIK, R. A lógica do caos. Carta na Escola, 24-26, 2008. Disponível em: <www.raquelrolnik. wordpress.com/2008/06/29/a-logica-do-caos>. Acesso em: 13 maio 2011.

SANTOS, M. A Urbanização Desigual: a especificidade do fenômeno urbano em países subdesenvolvidos. São Paulo: Hucitec, 1993.

SANTOS, M. \& SOUZA, M. A. (Org.). A Construção do Espaço. São Paulo: Nobel, 1986.

SILVA, J. S. et al. O que é Favela, Afinal? Rio de Janeiro: Observatório de Favelas, 2009. Disponível em: www.observatoriodefavelas.org.br/observatoriodefavelas/acervo/publicacoes.php >. Acesso em: 19 maio 2011.

SILVA, M. A. M. A morte ronda os canaviais paulistas. Revisa Abra, 33(2): 11-143, 2006.

SOARES, W. L. Uso dos Agrotóxicos e seus Impactos à Saúde e ao Ambiente: uma avaliação integrada entre a economia, a saúde pública, a ecologia e a agricultura, 2010. Tese de doutorado, Rio de Janeiro: Programa de Saúde Pública da Escola Nacional de Saúde Pública Sergio Arouca da Fundação Oswaldo Cruz (Ensp/Fiocruz).

WANDERLEY, M. N. B. A emergência de uma nova ruralidade nas sociedades modernas avançadas: o 'rural' como espaço singular e ator coletivo. Estudos, Sociedade e Agricultura, 15: 87-145, 2000. 


\title{
5 \\ Injustiça Ambiental, Mineraçẫo e Siderurgia
}

\author{
Bruno Milanez ${ }^{1}$ \\ Gabriela Scotto \\ Horácio Antunes de Sant'Ana Júnior \\ Dário Bossi \\ Karina Kato
}
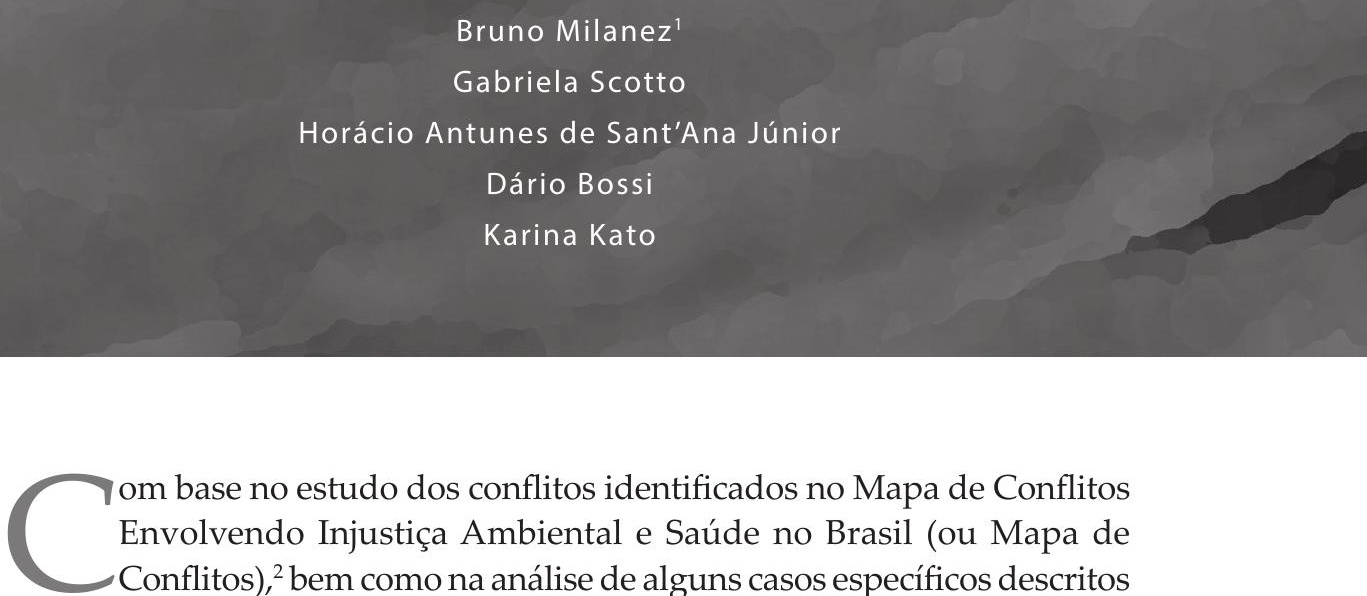

om base no estudo dos conflitos identificados no Mapa de Conflitos Envolvendo Injustiça Ambiental e Saúde no Brasil (ou Mapa de Conflitos), ${ }^{2}$ bem como na análise de alguns casos específicos descritos neste capítulo, argumentamos que a ampliação recente das atividades mineradoras e siderúrgicas no Brasil vêm não apenas intensificando passivos e conflitos históricos entre essas atividades e comunidades locais, mas também gerando novas injustiças ambientais nos territórios.

A mineração é uma atividade intensiva em recursos naturais, especialmente no uso do solo e da água. A introdução da atividade mineradora nos territórios - e não raro a sua especialização nesse setor - compete diretamente com outras formas de uso dos recursos naturais locais e, em muitos casos, coloca em risco outras formas de produção, em particular aquelas que dependem diretamente do meio ambiente, como a agricultura, a pesca, o turismo, entre outras. Como é uma atividade intensiva em capital, a mineração normalmente gera, em sua fase de operação, uma quantidade restrita de empregos, geralmente de baixa qualidade, reforçando um ciclo perverso de reprodução de desigualdades socioeconômicas. Ainda, a maior

\footnotetext{
${ }^{1}$ Todos os autores são membros do Grupo de Trabalho Articulação Mineração e Siderurgia, da Rede Brasileira de Justiça Ambiental.

${ }^{2}$ Disponível em: <www.conflitoambiental.icict.fiocruz.br>.
} 
parte dos postos de trabalho gerados não exige mão de obra qualificada, pouco contribuindo para a qualificação profissional nas regiões.

A atividade siderúrgica, por sua vez, ainda que muitas vezes justificada por ser uma estratégia de 'agregação de valor', apresenta várias das limitações identificadas na mineração. A proposta de novas instalações siderúrgicas normalmente vem acompanhada por argumentos de que essa atividade criaria mais empregos, como também aumentaria a receita pública em razão do pagamento de tributos. Porém, assim como na mineração, muitos empregos criados pela siderurgia expõem a saúde dos trabalhadores a uma série de riscos, e a implantação desses empreendimentos, usualmente, é condicionada a financiamentos públicos (muitas vezes pouco transparentes) e a renúncias fiscais. Além disso, podem ser importantes fontes de contaminação do solo, água e ar, bem como geradoras de agravos à saúde da população.

Como forma de ilustrar essas questões, optamos por apresentar em maiores detalhes problemas e conflitos relacionados à cadeia do ferro e aço, uma vez que o minério de ferro, em 2009, respondeu por 59\% de todas as operações minerais monitoradas pelo Departamento Nacional de Produção Mineral (DNPM, 2010).

Este capítulo está organizado em quatro seções. Em primeiro lugar, apresentamos um breve diagnóstico dos conflitos envolvendo injustiças ambientais e saúde relacionados às atividades de extração e beneficiamento mineral. Em seguida, descrevemos a situação do mercado de ferro e aço, argumentando que a atual conjuntura tem grande potencial de ampliar os conflitos existentes, bem como de gerar novos focos de disputa. Na seção seguinte, examinamos quatro estudos sobre conflitos na área de mineração de ferro e siderurgia.

Os casos nos permitem ilustrar, de forma objetiva, conflitos relacionados a toda a cadeia produtiva: o sistema Minas-Rio inclui a instalação de mina (Conceição de Mato Dentro - MG), a construção de um mineroduto e a implantação de um porto (São João da Barra - RJ); o exemplo de Pequiá de Baixo (Açailândia - MA) apresenta problemas associados à fabricação de ferro-gusa; e os casos de São Luís (MA) e da Companhia Siderúrgica do Atlântico (TKCSA), na baía de Sepetiba (RJ), constituem conflitos associados à instalação e operação de unidades produtoras de aço.

A opção por dois casos de siderúrgicas se deve ao fato de eles contarem duas partes de uma mesma história. A usina originalmente prevista para ser instalada em São Luís não obteve a licença ambiental em virtude da mobilização social contrária à sua instalação, e foi transferida para a baía de Sepetiba. 
Na seção final do texto, apresentamos as conclusões e algumas preocupações sobre os prováveis impactos decorrentes da intensificação das atividades de extração e beneficiamento mineral no Brasil e na América Latina.

\section{Conflitos Relacionados à Extração e ao Beneficiamento de Recursos Minerais}

Quando consultamos o Mapa de Conflitos em dezembro de 2010, identificamos 31 casos relacionados à extração de minérios e 21 casos associados ao beneficiamento mineral (Fiocruz/Fase, 2009).

Os conflitos causados pelas atividades de mineração povoam todas as regiões do país, com especial destaque para Região Norte (13 casos) e Sudeste (sete casos). A concentração de casos nessas Regiões foi em razão, principalmente, da quantidade de conflitos identificados no Pará (cinco casos) e em Minas Gerais (cinco casos), os dois principais estados mineradores do país. O Quadro 1 apresenta os minerais associados aos conflitos em cada uma das regiões.

Entre os conflitos identificados, destacamos aqueles relacionados ao ouro e ao diamante na Região Norte, todos eles associados a garimpos. A extração de minério de ferro também gera conflitos que se estendem por três Regiões (Sudeste, Nordeste e Norte). Contudo, nesses casos, os conflitos estão associados à atuação de grandes empresas transnacionais. Outro minério importante é o amianto que, apesar de hoje ter sua principal fonte de extração em Goiás, deixou importantes passivos na Região Nordeste. $\mathrm{O}$ amianto é uma fibra altamente tóxica e cancerígena, banido em vários países, mas, apesar dos protestos e inúmeras restrições em alguns estados e municípios, continua sendo produzido no Brasil (Castro, Giannasi \& Novello,

Quadro 1 - Distribuição regional dos conflitos associados à extração mineral por tipo de minério

\begin{tabular}{|l|l|}
\hline Região & Minérios \\
\hline Norte & $\begin{array}{l}\text { argila (PA), bauxita (PA), diamante (RO), ferro (PA, TO), } \\
\text { manganês (AP), níquel (PA), ouro (AM, RO, RR), torianita (AP) }\end{array}$ \\
\hline Nordeste & amianto (BA, RN), chumbo (BA), ferro (BA), urânio (BA) \\
\hline Sudeste & bauxita (MG), chumbo (SP), ferro (MG, RJ), ouro (MG), zinco (MG) \\
\hline Sul & carvão (SC), chumbo (PR), fosfato (SC) \\
\hline Centro-Oeste & amianto (GO) \\
\hline
\end{tabular}

Fonte: Mapa de Conflitos Envolvendo Injustiça Ambiental e Saúde no Brasil. 
2003). Os conflitos relativos à extração de carvão mineral atualmente estão relacionados à produção de carvão energético (para termelétricas), mas muitos dos passivos históricos desta atividade se devem ao período em que o carvão alimentava as siderúrgicas nacionais.

As atividades de extração de minérios foram associadas a diferentes danos e riscos à saúde. Alguns deles são específicos das propriedades dos minérios, como no caso do amianto (câncer de pulmão) e chumbo (deformações congênitas). Outros, contudo, causam danos derivados da atividade de extração em si, e se desdobram em problemas de saúde do trabalhador (doenças pulmonares e de pele) e em questões decorrentes da falta de infraestrutura dos territórios no momento em que são criados garimpos ou grandes projetos de mineração (doenças transmissíveis pela água, alcoolismo, aumento da violência etc.).

Quando consideramos os casos de conflitos e injustiças ambientais relacionados ao beneficiamento mineral, os estados que mais se destacam são o Pará e o Maranhão. Conforme o Quadro 2, esses conflitos estão fortemente associados ao complexo Carajás e à produção de carvão vegetal, ${ }^{3}$ ferro-gusa e aço.

Quadro 2 - Distribuição regional dos conflitos associados ao beneficiamento mineral

\begin{tabular}{|l|l|}
\hline Região & Minérios \\
\hline Norte & alumínio (PA), caulim (PA), siderurgia ${ }^{4}(\mathrm{PA})$ \\
\hline Nordeste & carvão vegetal (BA, MA), siderurgia (CE, MA) \\
\hline Sudeste & $\begin{array}{l}\text { alumínio (SP), amianto (SP), carvão vegetal (MG), } \\
\text { siderurgia (ES, MG, RJ, SP) }\end{array}$ \\
\hline Sul & alumínio (PR), siderurgia (SC) \\
\hline Centro-Oeste & carvão vegetal (MS) \\
\hline
\end{tabular}

Fonte: Mapa de Conflitos Envolvendo Injustiça Ambiental e Saúde no Brasil.

O Quadro 2 mostra ainda o forte impacto da produção de ferro-gusa e aço nos territórios, uma vez que 15 dos 21 conflitos identificados no mapa têm relação com esse setor. Além disso, o mapa ilustra conflitos associados ao beneficiamento da bauxita (alumínio), caulim e amianto.

\footnotetext{
${ }^{3}$ Apesar da produção de carvão vegetal não ser uma atividade de beneficiamento mineral, ela é diretamente associada à produção de ferro-gusa e, por isso, foi incluída nesta análise.

${ }^{4}$ Nesse contexto, consideramos siderurgia a produção de ferro-gusa, ferro fundido e aço.
} 
Os problemas e riscos à saúde associados ao beneficiamento de minério de ferro no Brasil, por sua vez, ocorrem em diferentes etapas da cadeia produtiva. A produção de carvão vegetal talvez seja a etapa com impactos mais extensivos, que incluem a concentração fundiária, a insegurança alimentar e a contaminação por agrotóxicos associadas à expansão da monocultura do eucalipto, além de trabalho infantil e escravo nas carvoarias. Ao mesmo tempo, diferentes guseiras e usinas siderúrgicas apresentam problemas de gestão ambiental, que se refletem na poluição atmosférica e contaminação de corpos d'água. Alguns desses aspectos serão apresentados nas próximas seções.

\section{O Brasil e o Mercado de Ferro e Aço}

Em virtude de suas grandes reservas de minério de ferro, o Brasil ocupa um lugar de destaque na cadeia de ferro e aço. Resumiremos a seguir as principais características dos setores de minério de ferro, ferro-gusa e aço.

O Brasil tem 9,8\% das reservas de minério de ferro do mundo, estando em quinto lugar, atrás da Ucrânia (20\%), Rússia (16,5\%), China (13,5\%) e Austrália (13,2\%). Em 2007, os maiores produtores foram China, Brasil, Austrália, Índia e Rússia (DNPM, 2009). Somente esses cinco países, naquele ano, foram responsáveis por $87 \%$ da produção de minério de ferro do mundo (World Steel Association, 2009).

No Brasil, em 2008, a produção de minério de ferro era realizada por 36 empresas, que operavam 53 minas, todas a céu aberto. O mercado, porém, é bastante concentrado, uma vez que a Vale, Minerações Brasileiras Reunidas (MBR) e Samarco respondem por 84\% da produção nacional (DNPM, 2009).

Ao longo dos anos 2000, a produção brasileira de minério de ferro passou por um momento de grande expansão, principalmente para atender à demanda da China. Segundo dados do Ministério do Desenvolvimento, Indústria e Comércio Exterior - MDIC - (Brasil, 2010b), entre 2000 e 2009 as exportações totais de minério de ferro do Brasil passaram de 157 milhões para 266 milhões de toneladas. Nesse mesmo período, as exportações para a China aumentaram de 15 milhões para 166 milhões de toneladas.

Embora não tão importante como no caso do minério de ferro, o Brasil também se destaca como fornecedor internacional de ferro-gusa. Em 2007, o país foi o sexto maior produtor mundial de ferro-gusa, com $4 \%$ da produção, e o segundo maior exportador. Em 2008, ele passou para a quinta posição no ranking de produção e para a liderança das exportações, com $37 \%$ das vendas globais (World Steel Association, 2010). Naquele ano, os principais 
importadores do ferro-gusa brasileiro foram Estados Unidos, 60\%, Formosa, 8\%, e Tailândia, 6\% (IBS, 2009).

A produção de ferro-gusa pode ocorrer tanto em usinas integradas, que o utilizam na produção de aço, como em guseiras independentes, que vendem seus produtos para as aciarias ou para fundições. A estrutura do setor de ferro-gusa no Brasil é muito pulverizada; em 2006 existiam 79 guseiras que, apesar de estarem presentes em cinco estados, concentravam-se em torno de Minas Gerais e do polo Carajás. As guseiras localizadas em Minas abastecem principalmente o mercado doméstico, ao passo que aquelas situadas no corredor Carajás exportam quase toda a sua produção (Sindifer, 2007).

Diferente do setor de ferro-gusa, a indústria de fabricação de aço apresenta uma estrutura bastante concentrada. Isso se deve, principalmente, à escala de produção que exige empresas maiores, bem como à própria trajetória do mercado siderúrgico nacional, consolidado por meio do capital estatal. Essa concentração se acentuou a partir da década de 1990, quando o setor foi radicalmente transformado, com o processo de privatização, fusão e internacionalização das empresas. Se no início da década de 1980 existiam 21 grupos siderúrgicos no país, em 2007 havia apenas oito (IBS, 2008).

O Brasil também se coloca em posição de destaque no mercado internacional de aço, embora com menos importância do que no caso do ferro-gusa e do minério de ferro. Em 2007, o país foi o nono maior produtor de aço bruto do mundo (2,5\% da produção mundial) e o $13^{\circ}$ maior exportador (World Steel Association, 2009). Segundo estimativas do Ministério de Minas e Energia, em 2015, a capacidade de produção brasileira deve chegar a 80 milhões de toneladas de aço bruto, subindo para 109 milhões de toneladas até 2025 . As exportações, por sua vez, devem alcançar um pico de 34,8 milhões de toneladas em 2015, porém estabilizando em 28,9 milhões de toneladas em 2025 (Brasil, 2009b).

Desde 2003, a participação da exportação oscila entre 35\% e $40 \%$ da produção, e caiu para menos de 30\% em 2008, em virtude da crise econômica mundial (IBS, 2003, 2007, 2009). Entretanto, os diferentes tipos de aço (produto semiacabado ou refinado) têm características distintas. Os produtos semiacabados são produtos mais simples e consistem em placas, lingotes e blocos de aço. As siderúrgicas localizadas no Brasil vendem por ano aproximadamente 7 milhões de toneladas de aço semiacabado e exportam essa quantidade em quase sua totalidade. Aços laminados, por sua vez, dizem respeito a produtos mais elaborados, como bobinas, chapas, aços especiais, tubos, entre outros. O mercado doméstico consome, anualmente, algo da 
ordem de 17 milhões de toneladas, o equivalente a quase $80 \%$ da produção nacional de aços refinados; as 5 milhões de toneladas restantes são exportadas (IBS, 2003, 2007, 2009).

Todavia, a tendência atual de comportamento das empresas transnacionais indica que a relação entre exportação de aço semiacabado e aço refinado deve mudar no futuro próximo. Nos últimos anos, as indústrias globais têm distribuído sua capacidade produtiva de forma a concentrar a 'fase quente' do processo siderúrgico (que inclui a produção de ferro-gusa e produtos semiacabados) nos países periféricos, mantendo a 'fase fria' (menos poluente, com menor gasto energético e com produtos de maior valor agregado) próxima aos mercados consumidores dos países centrais (Bühler, 2007).

Esse reposicionamento do Brasil dentro do mercado global tem provocado uma intensificação da produção de aço no país, não mais para abastecer o mercado doméstico, mas para atender a demanda de outros países. Essa tendência tem causado uma nova distribuição dos empreendimentos mínero-metalúrgicos no território nacional. Atualmente, a infraestrutura produtiva está se deslocando para o litoral, na medida em que isso favorece a logística de importação de carvão mineral e de exportação do aço, reduzindo bastante os custos logísticos. A partir dessa dinâmica, diferentes conflitos envolvendo a instalação desses empreendimentos surgem no mapa, como no caso do complexo de Pecém (São Gonçalo do Amarante - CE), São Luís e baía de Sepetiba; os dois últimos descritos em mais detalhes na próxima seção.

\section{Os Casos}

\section{Sistema Minas-Rio ${ }^{5}$}

O chamado Sistema Minas-Rio, empreendimento da Anglo Ferrous Minas-Rio Mineração S. A. (empresa criada em agosto de 2008 pela Anglo American), ${ }^{6}$ inclui no seu projeto inicial a exploração de minério na serra do Sapo, na região de Conceição do Mato Dentro (MG), e uma usina de

\footnotetext{
${ }^{5}$ Ver, no Mapa da Injustiça Ambiental e Saúde no Brasil, os casos:"Fragilidade no processo de licenciamento ambiental do Complexo Portuário de Açu coloca em risco comunidades de 32 municípios dos estados de Minas Gerais e Rio de Janeiro" e "Mineração e transposição de águas para grande empresa é licenciada de forma irregular pelos governos estadual e federal, condenando uma das áreas com patrimônio natural e cultural mais significativos de Minas Gerais".

${ }^{6}$ Com sede em Londres e com uma atuação global, a maior parte das operações da Anglo American está localizada no sul da África. A empresa foi fundada na África do Sul em 1917. No Brasil, o grupo Anglo American foi instalado em 1973 e possui as unidades de negócio Metais Básicos (Anglo American Brasil) e Minério de Ferro (Anglo American, 2010). O projeto Minas-Rio foi iniciado pela MMX Metal e Metálicos e adquirido em 2008 pelo grupo Anglo American.
} 
beneficiamento em Alvorada de Minas (MG); um mineroduto ('corredor logístico') com $525 \mathrm{~km}$ de extensão, que atravessa 32 municípios mineiros e fluminenses; e ainda a participação de $49 \%$ no terminal de minério do porto do Açu, uma joint venture com a LLX, uma das empresas do grupo EBX, de Eike Batista, situado em São João da Barra (RJ). Atualmente, o projeto é o maior investimento da Anglo American no mundo. Segundo informações da própria empresa, quando o sistema Minas-Rio entrar em operação, deverá produzir 26,5 milhões de toneladas anuais de minério de ferro, cujo destino principal é o mercado externo.

O minério a ser extraído será escoado, como polpa, por um mineroduto subterrâneo de $525 \mathrm{~km}$ de extensão, ligando a usina de beneficiamento, em Conceição do Mato Dentro, ao porto do Açu, em São João da Barra, ameaçando 24 municípios mineiros e sete fluminenses, além de Conceição do Mato Dentro e também a histórica cidade do Serro, uma das principias atrações turísticas do estado, no trajeto da Estrada Real. Próximo às minas deve haver cerca de cinquenta grutas.

Fundado em 1840, o município de Conceição do Mato Dentro está localizado no meio da serra do Espinhaço, uma área de extrema relevância ambiental que foi declarada reserva da biosfera pela Organização das Nações Unidas para a Educação, a Ciência e a Cultura (Unesco). A área foi considerada pela Unesco, em 27 de junho de 2005, a sétima reserva da biosfera brasileira em razão da sua grande diversidade de recursos naturais. Mais da metade das espécies de animais e plantas ameaçados de extinção em Minas Gerais estão nas cadeias do Espinhaço e, especialmente, na serra do Cipó, onde se encontra o maior número de espécies endêmicas da flora brasileira. As raízes africanas, europeias e indígenas se misturam no Espinhaço, deixando marcas nos costumes e manifestações culturais das comunidades locais. A beleza e a cultura da região oferecem excelentes condições para o desenvolvimento do ecoturismo (Unesco, 2006).

Conceição do Mato Dentro, distante 168 km de Belo Horizonte e próximo ao Parque Nacional da Serra do Cipó, tem um notável patrimônio histórico, datado do século XVIII, grandiosas riquezas naturais, como a segunda mais alta queda d'água do Brasil, a cachoeira do Tabuleiro, e igualmente grandiosa diversidade sociocultural. O turismo, base econômica da cidade histórica de Conceição, está prestes a ter de enfrentar a concorrência da mineração, embora sejam conhecidos o valor ambiental e paisagístico da serra do Espinhaço e a necessidade de cuidados especiais e de limites para a prática da mineração. 
O mineroduto, licenciado pelo Instituto Brasileiro do Meio Ambiente e dos Recursos Naturais Renováveis (Ibama), vem sendo construído em plena serra do Espinhaço e irá atravessar uma bacia hidrográfica de grande importância, com fortes impactos negativos em cerca de seiscentos cursos d'água e até no próprio mar territorial brasileiro, já que a água que levará o minério será despejada no oceano pelo porto do Açu. Uma quantidade importante da água de Conceição do Mato Dentro será disponibilizada de forma exclusiva e permanente para o transporte do minério por meio do bombeamento de uma pasta composta de água misturada ao minério. Segundo o Observatorio de Conflictos Ambientales en América Latina (OCMAL), dentre os potenciais e reais problemas ligados ao empreendimento, devem ser destacados os seguintes: a remoção de $2.500 \mathrm{~m}^{3}$ de água por hora e os novos custos à população; a destruição de reservatórios naturais de água, que comprovadamente coabitam com as jazidas de ferro na região central de Minas, em favor da política de produção e exportação de minério; processo de aquisição das propriedades nas áreas das jazidas sondadas em Conceição; perdas de patrimônio histórico-cultural; impactos sobre os povos e comunidades tradicionais (OCMAL, 2009).

A mina e a grande barragem de rejeitos do projeto Minas-Rio afetarão também áreas onde residem duas comunidades remanescentes de quilombos. Os processos de coação das comunidades e o cerceamento do direito de ir e vir têm sido denunciados desde o início de 2009. Milícias armadas se assenhorearam de logradouros públicos e cobram identificação daqueles que passam pelos caminhos. No início, carros da empresa chegaram a cercar os do Ibama e do próprio Instituto Estadual de Florestas (IEF), que iriam vistoriar a região (Fiocruz/Fase, 2009). ${ }^{7}$

Parte da população, ambientalistas e algumas organizações não governamentais (ONGs) têm se posicionado de forma contrária ao projeto MinasRio. Esses grupos alertam para o fato de o Sistema Estadual de Meio Ambiente (Sisema) dar pouca atenção aos impactos e permitir o licenciamento de empreendimentos altamente degradantes. Até mesmo algumas prefeituras da região, o estado de Minas Gerais, a Companhia de Saneamento de Minas Gerais (Copasa) e o Instituto de Gestão das Águas (Igam) chegam a reconhecer que os reservatórios de água para abastecimento público têm sido deteriorados pelas lavras. Por sua vez, o Secretário de Meio Ambiente e Turismo de Conceição do Mato Dentro reforçou que, além das alterações

\footnotetext{
${ }^{7}$ Vários desses episódios e situações de constrangimento da população tradicional estão registrados nos vídeos Conceição: guarde nos olhos (Valle, 2009).
} 
ambientais negativas previstas para o empreendimento, a região já sofre com outros sérios problemas de degradação.

Outro aspecto que preocupa a população é que o projeto de mineração de ferro vai ocorrer numa região sabidamente rica em ouro e diamantes. Segundo informações que circulam entre as pessoas do local, incluindo-se alguns deputados, a MMX teria adquirido direitos minerários de pessoas físicas e empresas de pequeno porte e sem capacidade de investimento, o que nos leva a suspeitar que esteja havendo a emissão e a transferência de titularidade desses direitos para grandes empresas.

Embora o Sistema Minas-Rio seja o único projeto integrado, foi licenciado de forma fragmentada, ainda que seja óbvio que nenhuma dessas estruturas (mina, mineroduto e porto) funcione uma sem a outra. A mina foi objeto de licenciamento pelo estado de Minas Gerais; o mineroduto foi licenciado pelo Ibama, como se tal duto pudesse funcionar sem o minério que vem da mina; e, finalmente, o porto do Açu vem sendo licenciado pelo estado do Rio de Janeiro, por meio do Instituto Estadual do Ambiente (Inea). O Movimento pelas Serras e Águas de Minas denuncia como prática corrente dos governos municipais, estadual de Minas e da União anuir ou promover o fracionamento de empreendimentos em diferentes etapas ou fases de instalação e operação, como se a avaliação por partes fosse idêntica à avaliação de seu conjunto.

No dia 12 de agosto de 2009, o Ministério Público Federal (MPF) entrou com uma ação civil pública no órgão da Justiça Federal em Belo Horizonte para impedir a continuidade das obras de instalação do mineroduto Minas-Rio. São réus nessa ação o Ibama, o estado de Minas Gerais, a MMX Minas-Rio Mineração e Logística Ltda., a Anglo Ferrous MinasRio Mineração, a LLX Açu Operações Portuárias S.A., a LLX Minas-Rio Logística Comercial Exportadora S.A. e o Inea, do Rio de Janeiro. O MPF solicitou que a Justiça concedesse liminar determinando a paralisação imediata de qualquer atividade de construção do mineroduto Minas-Rio e suspendesse os efeitos da licença prévia da mina Sapo-Ferrugem, das licenças prévias e de instalação do mineroduto, e das licenças prévias e de instalação do porto do Açu. Pediu ainda que, ao final da ação, fosse decretada a nulidade dos procedimentos de licenciamento e das licenças concedidas até o momento e que fosse atribuída ao Ibama a responsabilidade do processo de licenciamento, considerando-o como um todo único e indissolúvel formado pelo conjunto mina-mineroduto-porto.

Para a procuradora Zani Cajueiro Tobias de Souza, a fragmentação do empreendimento foi totalmente ilegal e realizada dessa forma para driblar 
os diversos entraves ambientais que certamente teriam de ser enfrentados em um procedimento de licenciamento único. Um empreendimento que provoca impactos em mais de uma unidade da federação, com significativa degradação ambiental, atingindo uma localidade reconhecida pela Unesco como reserva da biosfera, comunidades tradicionais, áreas de Mata Atlântica em estágio primário, áreas de preservação permanente, além do próprio mar territorial brasileiro, por força da legislação nacional deve ter o processo de licenciamento conduzido pelo Ibama. No entanto, segundo o MPF, "em inusitada decisão administrativa, o empreendimento foi fracionado" (Fiocruz) Fase, 2009).

Alguns dias depois da ação civil pública iniciada em Belo Horizonte, foi a vez de a procuradoria do MPF no Rio de Janeiro ajuizar ação similar pedindo liminar para que fossem paralisadas as obras do porto do Açu. Dessa vez, os motivos seriam o fato de o empreendimento não ter sido licitado, a cessão da área para o porto ter sido indevida, e a licença ambiental do empreendimento ter sido concedida sem a aprovação do estudo de impacto ambiental. O MPF pediu também que fosse declarada a inconstitucionalidade da lei que regulamenta os portos brasileiros, a lei n. 8.630/93 (Brasil, 1993) que permite a privatização sem fiscalização do poder público, o que é vedado pela Constituição, pois apenas a União poderia explorar os portos marítimos, diretamente ou por delegação (Fiocruz/Fase, 2009).

Até julho de 2013, o projeto não tinha ainda entrado em operação. Segundo a Anglo (2012), as dificuldades de obtenção das licenças ambientais seriam as responsáveis pelo atraso da execução do projeto do Minas-Rio e pelo aumento do custo do empreendimento.

\section{Pequiá de Baixo (Açailândia - MA)}

Em audiência pública na Assembleia Legislativa do Maranhão realizada em novembro de 2010, ${ }^{8}$ Açailândia foi reconhecida como símbolo dos grandes investimentos e projetos instalados no estado a partir da década de 1980, no bojo do Programa Grande Carajás. O tão declamado 'desenvolvimento' prometido naquela época não garantiu a distribuição de renda; ao contrário, manteve amplos bolsões de pobreza a serviço da produção industrial (principalmente para exportação) e atingiu as comunidades com um forte impacto ambiental.

\footnotetext{
${ }^{8}$ Audiência Pública "Açailândia pode parar", convocada na Assembleia Legislativa do Maranhão, no dia 23 de novembro 2010, pela deputada Helena Heluy (Justiça nos Trilhos, 2010a).
} 
A poucas dezenas de metros do povoado de Pequiá de Baixo, no município de Açailândia, instalaram-se, no final da década de 1980, 15 altosfornos siderúrgicos, aos quais se seguiram três usinas termelétricas e, mais recentemente, uma aciaria, uma fábrica de gases e uma fábrica de cimento. Todos esses empreendimentos pertencem às empresas Gusa Nordeste, Viena Siderúrgica, Ferro Gusa do Maranhão, Simasa e Pindaré (essas últimas duas do grupo Queiróz-Galvão). A Vale fornece minério de ferro às siderúrgicas e transporta o produto de tais usinas para exportação, e o seu pátio de carregamento e descarregamento se encontra no próprio Pequiá.

Cercadas por esse grande polo industrial, 356 famílias do povoado, que já moravam no local antes da instalação das empresas, sofrem um grave impacto socioambiental, em boa parte desde o começo dos empreendimentos. ${ }^{9}$

Um relatório de perícia ambiental, realizado pelo biólogo e pesquisador Ulisses Brigatto (2007), fornece suficientes informações a respeito desse impacto. ${ }^{10}$ Destacamos os seguintes elementos:

1) Fuligem e poeira - em todas as casas periciadas, nos móveis e nos utensílios de cozinha, deposita-se cotidianamente fuligem, contendo resíduos provenientes do aquecimento do ferro, e poeira, do peneiramento do minério e da trituração de escória. A direção prevalente dos ventos é exatamente no sentido usinas-casas.

2) Gases de fornos - o processo de combustão e síntese química do ferro com carvão produz gases $\left(\mathrm{CO}_{2} \mathrm{e} \mathrm{CO}\right)$ emitidos pelas chaminés das empresas. Trata-se dos principais gases responsáveis pelo aquecimento global.

3) Água de esfriamento - captada no ribeirão Pequiá, é utilizada para reduzir a temperatura dos altos-fornos e devolvida ao rio aquecida e com resíduos de ferro. A drenagem das chuvas também leva o material particulado disperso no pátio das empresas até o mesmo rio.

4) Escória - os resíduos sólidos da produção não são inteiramente tratados e reciclados e são abandonados em pátios ao ar livre.

\footnotetext{
${ }^{9}$ Prova disso é a escola municipal do bairro, construída em 1970.

${ }^{10}$ A realização da perícia foi estabelecida pela juíza da segunda Comarca do Fórum de Açailândia depois dos vinte processos de moradores de Pequiá contra uma das empresas guseiras (Gusa Nordeste). O relatório foi realizado com base em pesquisas feitas no pátio da própria empresa e nas casas dos moradores. Os impactos detectados no caso da Gusa Nordeste são suficientemente representativos também em relação às outras guseiras.
} 
Concentrando altos teores calcários, podem gerar problemas de alcalinização e intoxicar plantas, animais e pessoas. O depósito de escória provocou vários acidentes de queimaduras de animais e pessoas. Uma criança de Pequiá morreu em 1999 por queimaduras graves, depois de afundar até a altura da bacia no amontoado de resíduos incandescentes num dos pátios da empresa Gusa Nordeste.

5) Ruídos - a instalação das termoelétricas aumentou os ruídos permanentes que ressoam no povoado dia e noite, tornando-se às vezes insustentáveis e atrapalhando o descanso da população.

6) Desmatamento - nas primeiras décadas de funcionamento, as guseiras utilizavam carvão vegetal originado basicamente de resíduos de serraria e de extração de mata nativa (Assis \& Carneiro, 2012). Em estudo do Ibama, aprende-se que as guseiras do Maranhão declararam utilizar, em 2005, carvão vegetal vindo de resíduos de serraria $(52 \%)$, desmatamento $(26 \%)$, coco babaçu $(13 \%)$ e reflorestamento (7\%) (Ibama, 2005). ${ }^{11}$

7) Monocultura de eucalipto - o objetivo da autossustentação das guseiras, ${ }_{1}^{12}$ por um lado, reduz o impacto na mata nativa, por outro, agride os territórios reduzindo cada vez mais as oportunidades para a agricultura familiar e incentivando um provável "processo de extinção de inúmeros rios, mananciais, fontes d'água" (Defensoria Pública do Estado de São Paulo, 2010)..$^{13}$

Oimpacto sobre a saúde dos moradores, consequentemente, é indiscutível, principalmente afecções no trato respiratório superior (dor ou problemas na garganta, tosse, fluxo nasal ou dor de ouvido, dificuldades para respirar) e problemas de vista, irritação nos olhos ou lacrimejamento. ${ }^{14}$

\footnotetext{
${ }^{11}$ Com base em dados apresentados pelas próprias guseiras, o lbama identificou o consumo entre 2000 e 2005 de 7,7 milhões de $\mathrm{m}^{3}$ de carvão ilegal e de 15,4 milhões de $\mathrm{m}^{3}$ de toras de madeira exploradas sem autorização (Portal Ecodebate, 2005).

${ }^{12}$ O grupo Queiroz Galvão (duas empresas em Açailândia) tinha 31 mil hectares de florestas plantadas em 2007; Viena Siderúrgica, pouco mais de 15 mil ha; Gusa Nordeste, até final de 2009, 30 mil ha.

${ }^{13} \mathrm{O}$ defensor público alega que a monocultura de eucalipto tem um "altíssimo poder de sucção"e na região de Taubaté, após a década de 1980, o ciclo do monocultivo provocou um visível assoreamento dos cursos de água.

${ }^{14}$ Em pesquisa realizada em setembro 2010 pela ONG Justiça Global (RJ), aplicando um questionário em mais de $80 \%$ das casas de Pequiá de Baixo, detectou-se que $56,5 \%$ da população teve seu estado de saúde relatado como "ruim ou muito ruim" e somente $12,4 \%$ como "bom ou muito bom". No Brasil, estimativas da Pesquisa Nacional por Amostra de Domicílios (Pnad) em 2008, apontam que 77,3\% da população avaliam o seu estado de saúde como "muito bom ou bom" e apenas 3,8\% como "ruim ou muito ruim".
} 
Apesar dessas evidências, muitas pessoas em Açailândia ainda dependem do emprego oferecido pelo ciclo de mineração e siderurgia. Os empregos diretos nas guseiras são cerca de $2.600 .^{15} \mathrm{~A}$ crise econômico-financeira de 2008 e o aumento do preço do minério de ferro no ano seguinte provocaram, porém, uma drástica redução desse contingente de trabalhadores (no mês de novembro de 2010 trabalharam nas guseiras menos de mil pessoas, em turnos pesados e com cortes salariais). Assim, o Programa Grande Carajás trouxe à região uma economia de enclave, facilmente influenciada pelo preço internacional do ferro e pelas condições ditadas pelo monopólio da Vale.

Esse tipo de economia é implementado em espaço subperiférico e entendido como todo aquele que gira com capital e tecnologia exógenos, atraídos mediante vantagens competitivas estáticas (fundamentalmente incentivos fiscais). Na economia de enclave, os lucros retornam aos donos do capital residentes em outras regiões e a tecnologia do chão de fábrica é inteiramente assimétrica e sem sintonia com os insumos, os saberes e a cultura local.

O Estado foi o promotor dessa economia e ainda hoje favorece um desenvolvimento unicamente baseado nos grandes projetos, oferecendo incentivos fiscais e financiamentos para novos investimentos, mas permanecendo cúmplice e corresponsável pelo impacto socioambiental. De fato, a fiscalização dos empreendimentos e a disponibilização ao público dos dados de monitoramento são extremamente precárias; ao mesmo tempo, as licenças ambientais são concedidas com facilidade e, em alguns casos, sem as suficientes condicionantes, como demonstra o recente licenciamento para a duplicação da Estrada de Ferro Carajás.

Segundo integrantes da campanha Justiça nos Trilhos, que se ocupa das relações com as comunidades impactadas pela Vale e pelo ciclo de siderurgia na região de Carajás, nesse e em vários outros casos "o prejuízo é coletivo e o lucro privado" (Justiça nos Trilhos, 2010b). ${ }^{16}$

\section{Polo siderúrgico de São Luís}

A partir de 2001, uma onda de ameaças de deslocamento compulsório de povoados da zona rural de São Luís, capital do Maranhão, configurou-se

\footnotetext{
${ }^{15} \mathrm{Em}$ novembro de 2010 estavam empregadas na empresa Viena 240 pessoas. A capacidade de trabalho dessa empresa é de no máximo 1.000 vagas; no caso do grupo Queiroz Galvão, a relação entre empregos efetivos em novembro 2010 e a capacidade total de trabalho é 35/1.000; no caso da Gusa Nordeste, 250/500; da Fergumar, 250/400; das empresas de montagem a serviço das siderúrgicas, $250 / 800$.

${ }^{16}$ Desde 2007, a rede articula movimentos e comunidades da região para denunciar impactos socioambientais causados pela Vale e para buscar alternativas.
} 
a partir da tentativa de instalação de um gigantesco polo siderúrgico que envolvia uma ampla negociação da qual fizeram parte diretamente os Poderes Executivos federal, estadual e municipal. Esses poderes proporcionariam a infraestrutura necessária, incluindo-se a concessão da área para as instalações físicas e de incentivos fiscais, além da regularização dos aspectos legais que viabilizassem sua instalação. A negociação envolvia também os Legislativos estadual e municipal e a iniciativa privada, por meio da Companhia Vale do Rio Doce, ${ }_{17}^{17}$ que anunciou publicamente, em 2004, o interesse de grupos empresariais estrangeiros no empreendimento, tais como Baosteel Shanghai Group Corporation, chinês; Arcelor, francês; Pohang Steel Company-Posco, sul-coreano; e ThyssenKrupp, alemão (Alves, Sant'Ana Júnior \& Mendonça, 2007).

O denominado polo siderúrgico de São Luís seria composto de quatro grandes usinas siderúrgicas, três voltadas para produção de placa de aço e uma de ferro-gusa, beneficiando minério de ferro extraído na região de Marabá, no sudeste do Pará. O empreendimento teria como uma das vantagens a sua localização, nas proximidades do complexo portuário de São Luís, cujos portos são equipados para exportação de minérios e seus derivados, e da Estrada de Ferro Carajás, que faz a ligação entre as minas do Pará e o município de São Luís. O projeto inicial do polo previa também a utilização do carvão mineral extraído na China, o que manteria os navios sempre carregados de aço ou de carvão. Todo o projeto poderia contar com farta disponibilidade de energia elétrica e com de mão de obra abundante e barata, pelo menos para os serviços de construção civil, na sua fase de implantação (Fórum Carajás, 2012).

Em 2001, o governo do estado do Maranhão assinou um protocolo de intenções com a Companhia Vale do Rio Doce, tendo em vista a construção do polo siderúrgico e prevendo a destinação de uma área de 2.471,71 hectares, localizados na região administrativa municipal do Itaqui/Bacanga. Em 2004, essa área foi declarada de utilidade pública para fins de desapropriação pelo governo do estado - decretos estaduais n. 20.727 (Maranhão, 2004a) e n. 20.781 (Maranhão, 2004b) - o que implicava o deslocamento compulsório de seus moradores e daqueles que a utilizavam de forma produtiva. Tais moradores foram estimados em mais de 14.400 pessoas, distribuídas em 12 povoados (Vila Maranhão, Taim, Cajueiro, Rio dos Cachorros, Porto Grande, Limoeiro, São Benedito, Vila Conceição, Anandiba, Parnuaçu, Camboa dos Frades e Vila Madureira). Assim como em outros empreendimentos na região, no projeto

\footnotetext{
${ }^{17}$ A partir de 2007, a empresa passou a usar o nome Vale.
} 
do polo siderúrgico se operou com a noção de que a Amazônia brasileira seria um grande vazio demográfico, provocando a invisibilidade de agentes e grupos sociais localizados nas áreas de interesse estratégico para grandes projetos de desenvolvimento (Almeida, 1996).

Para viabilizar o deslocamento dos povoados, o governo do estado e a Companhia Vale do Rio Doce contrataram a empresa paulista Diagonal Urbana Consultoria Ltda. para fazer o diagnóstico sócio-organizativo da área (Mendonça, 2006). A Diagonal entrou em contato direto com os moradores, levantou dados e, afirmando que estavam proibidos novos plantios e a realização de benfeitorias nas casas, pois seriam indenizados somente pelo que foi cadastrado, chegou até a marcar com tinta preta e numerar as casas das famílias que deveriam ser deslocadas. O levantamento e a marcação das casas não foram feitos nos povoados Rio dos Cachorros e Taim, porque os moradores resistiram e impediram a entrada dos funcionários da Diagonal (Alves, Sant'Ana Júnior \& Mendonça, 2007).

Segundo a Lei de Zoneamento, Parcelamento, Uso e Ocupação do Solo (São Luís, 1992) do município de São Luís, em vigor desde 1992, a área planejada se localizava na zona rural II do município. A legislação brasileira sobre zoneamento urbano permite empreendimentos industriais somente em zona industrial, o que constituía um empecilho para a instalação do polo. Com o objetivo de eliminar esse obstáculo, a Prefeitura de São Luís encaminhou à Câmara Municipal um projeto de alteração da lei, convertendo a área em zona industrial. Essa ação do Executivo municipal abriu uma ampla polêmica, uma vez que a legislação brasileira prevê que alterações em leis de zoneamento, parcelamento, uso e ocupação do solo devem ser precedidas de consultas à população potencialmente afetada.

A pressão de movimentos sociais e a atuação do Ministério Público estadual e federal contra o projeto de lei do Executivo municipal desencadearam audiências públicas envolvendo os mais variados grupos sociais do município. Provocou também acalorados debates no Plenário da Câmara Municipal e a mobilização de moradores e de organizações que atuavam na área, de movimentos ambientais, sociais e populares, de entidades empresariais. Essas discussões se constituíram, assim, em um amplo debate público em que se confrontaram os defensores e os contrários à instalação do polo.

Entre os defensores, podemos destacar a Companhia Vale do Rio Doce, os governos municipal e estadual, setores do empresariado local (com destaque para a Associação Comercial do Maranhão e a Federação das Indústrias do Estado do Maranhão) e parte dos moradores dos povoados 
da área, principalmente os interessados na obtenção de indenização de terrenos e benfeitorias.

Do outro lado, questionando a viabilidade socioambiental do polo siderúrgico, estavam as organizações sociais dos povoados atingidos, a Igreja Católica (com pronunciamento contrário ao empreendimento do arcebispo de São Luís e com a atuação das paróquias da área) e o movimento Reage São Luís, que envolvia várias entidades sindicais, ambientais e populares, além de profissionais liberais, estudantes, pesquisadores e religiosos.

Os que defendiam a instalação do polo argumentavam que o projeto provocaria: incremento do desenvolvimento econômico da capital e do estado, possibilitando melhorar seus baixos índices de desenvolvimento econômico e humano; criação de cerca de 120.000 empregos diretos e indiretos; diversificação da estrutura social local, com a ampliação das oportunidades de emprego qualificado; incorporação de novas tecnologias produtivas, com modernas práticas administrativas e de prevenção de impactos ambientais; aumento da produção local de ciência e tecnologia via fortalecimento das instituições de ensino e pesquisa, principalmente para formação de mão de obra especializada; melhoria na balança comercial brasileira, ao agregar valor ao minério produzido no país, por meio de sua industrialização local (Alves, Sant'Ana Júnior \& Mendonça, 2007).

Aqueles que se posicionavam contrariamente ao empreendimento (ou, ao menos, à sua instalação na área prevista), por meio da imprensa local e de outros instrumentos de participação no debate público (reuniões, panfletos, participação em eventos), produziram e divulgaram análises técnicas e considerações sobre a pertinência da implantação de empreendimento de tamanho porte na Ilha do Maranhão.

Desses argumentos, destacamos duas ordens de possíveis consequências da implantação do polo:

1) Impactos ambientais - aumento do consumo de água potável (equivalente a 207 milhões de litros por dia, o que corresponde à totalidade de consumo atual da população do município de São Luís); emissão de 2,4 mil litros de vapor d'água por segundo, carregados de resíduos sólidos, e a emissão de 1,5 toneladas de dióxido de carbono para cada tonelada de aço produzida, comprometendo gravemente a saúde dos moradores de seu entorno e de toda a Ilha do Maranhão; alterações climáticas significativas; ameaça de destruição de 10 mil hectares de manguezais, ecossistema no qual parte da população explora tradicionalmente os 
recursos pesqueiros, tanto para o consumo próprio como para a produção de excedentes destinados ao mercado local, e que se constitui em uma das áreas de reprodução do peixe-boi e do mero, espécies marinhas ameaçadas de extinção.

2) Impactos sociais - deslocamento compulsório de cerca de 14.400 pessoas, algumas delas moradoras de povoados centenários e outras ali localizadas há mais de meio século; atração de grande contingente populacional para o município de São Luís, sem a devida infraestrutura urbana para abrigá-lo e sem áreas para expansão urbana que respeitem os níveis de sustentabilidade ambiental; ampliação da violência urbana; saturação dos serviços e equipamentos disponíveis no município.

A pressão de entidades e grupos sociais contrários à implantação do polo não impediu que a Câmara Municipal aprovasse a mudança na lei. No entanto, essa mesma pressão levou à alteração do projeto inicialmente enviado pelo Executivo municipal. Foram excluídas as áreas de preservação permanente, constituídas das nascentes e cursos d'água existentes e as áreas de recarga de aquíferos, ${ }^{18}$ o que reduziu a área convertida em zona industrial para 1.063,60 hectares (Fórum Carajás, 2012). Dessa forma, a nova zona industrial permitiria somente a instalação de uma usina siderúrgica, em vez das quatro inicialmente previstas. A redução da área disponibilizada para o polo frustrou as expectativas de sua instalação, e a Companhia Vale do Rio Doce abandonou o projeto.

A reação de parte dos moradores demonstrou que não aceitaram essa condição de invisibilidade e reivindicaram um assento nas mesas de negociação cujas decisões interfeririam diretamente em seu modo de vida, configurando-se uma situação de conflito ambiental (Acselrad, 2004). Na disputa pelo controle e uso da área em questão, algumas associações de moradores das localidades solicitaram ao Ibama que desse andamento ao pedido de constituição da reserva extrativista que era discutido desde 1996 e que foi demandado, por meio de abaixo-assinado, no ano de 2003.

\footnotetext{
${ }^{18}$ Em razão da sua conformação geológica, de forma afunilada, essas áreas acumulam águas das chuvas que, ao passarem para o subsolo, recarregam os aquíferos de água potável, atualmente responsáveis pelo abastecimento de cerca de $40 \%$ da água consumida pela população da Ilha do Maranhão. A impermeabilização do solo para a construção das usinas siderúrgicas poderia diminuir o processo de recarga e comprometer esses aquíferos, na medida em que sofrem permanentes pressões das águas salgadas do mar e sua não recarga pode levá-los à salinização.
} 
Segundo o depoimento de Alberto Cantanhede Lopes, mais conhecido como Beto do Taim, ${ }^{19}$ a demanda pela reserva extrativista é anterior ao debate em torno do projeto do polo siderúrgico e corresponde ao anseio de regularizar o uso e controle do território ancestralmente ocupado e de manter as possibilidades de reprodução social do grupo (Miranda, Maia \& Gaspar, 2009). O Ibama abriu o processo de implantação da reserva extrativista de Tauá-Mirim.

O processo de instalação da reserva cumpriu as fases legalmente previstas de elaboração de laudos biológicos e socioeconômicos e de consulta pública à população, com o objetivo de verificar se a demanda pela reserva correspondia efetivamente à vontade dos agentes sociais envolvidos. No final de 2010, depois de ter passado pelo exame do Ministério do Meio Ambiente, o processo foi encaminhado para a Casa Civil da Presidência da República e aguardava a sanção do presidente da República.

\section{Companhia Siderúrgica do Atlântico (TKCSA), baía de Sepetiba}

Na baía de Sepetiba, o conflito ambiental colocou em posições opostas, em uma primeira fase (pré-inauguração) da Companhia Siderúrgica do Atlântico (TKCSA), os empreendedores privados responsáveis pelo complexo industrial e portuário, receptores de significativo apoio do Estado, e os pescadores artesanais e outros segmentos sociais que habitam a baía de Sepetiba..$^{20}$ Os planos de se instalar na região polos industriais datam da década de 1960. Nos últimos anos, esses projetos foram retomados, e a baía de Sepetiba se tornou um dos maiores canteiros de obras do Brasil, com investimentos privados de, pelo menos, $\mathrm{R} \$ 38$ bilhões em terminais portuários, rodovias, siderurgias e centros de distribuição (Corecon-RJ, 2009). Tais projetos englobam a ampliação do porto de Itaguaí, a construção da TKCSA, de um terminal conjunto da Companhia Siderúrgica Nacional

\footnotetext{
${ }^{19}$ Líder no povoado do Taim, dirigente nacional do Movimento Nacional de Pescadores (Monape) e do Grupo de Trabalho Amazônico (GTA).

${ }^{20} \mathrm{~A}$ baía de Sepetiba abrange os municípios do Rio de Janeiro, Itaguaí e Mangaratiba e é uma região muito diversificada, com áreas industriais, florestais e residenciais. No município do Rio de Janeiro, os bairros mais próximos da baía são Guaratiba, Pedra de Guaratiba, Sepetiba, Campo Grande e Santa Cruz, com uma população de cerca de 646.199 pessoas de acordo com dados do IBGE em 2000. É uma das poucas áreas no Rio de Janeiro onde se podem encontrar manguezais e áreas de Mata Atlântica, e também é área de residência de populações que vivem da pesca artesanal e da agricultura, englobando comunidades remanescentes de quilombo e indígenas. Segundo dados da Fundação Centro de Informações e Dados do Rio de Janeiro, em 2006 cerca de 2.250 pessoas trabalhavam formalmente no turismo em Itaguaí e Mangaratiba. A Federação das Associações dos Pescadores Artesanais do Estado do Rio de Janeiro (Fapesca) estima em cerca de oito mil o número de pescadores artesanais da baía de Sepetiba.
} 
(CSN), Gerdau e Petrobras, o porto Sudeste e um estaleiro da Marinha (Gonçalves, 2010).

A TKCSA foi o primeiro megaempreendimento a se instalar na baía mais recentemente. É uma usina siderúrgica com um porto integrado com capacidade de produzir 5,5 milhões de toneladas de placas de aço por ano. Lançada em 2006 e inaugurada em 2010, a TKCSA é uma joint venture da Vale (27\%) e da ThyssenKrupp (73\%). Logo após sua inauguração, a usina agilizou a documentação para duplicar sua capacidade de produção, plano agora paralisado em virtude da crise no mercado internacional de aço. Ela não é apenas a maior siderúrgica da América Latina; em 2009, época do seu lançamento e posterior à crise financeira mundial, constituía o maior investimento privado em curso no Brasil (Corecon-RJ, 2009), o que lhe conferiu grande importância econômica e política. Toda a sua produção é destinada à exportação, parte para a Alemanha, parte para outra indústria da ThyssenKrupp no Alabama, Estados Unidos, onde as placas de aço são laminadas.

Muitos sãos os impactos negativos causados pela TKCSA sobre a população local, entre os principais podemos mencionar:

1) Impactos sobre a saúde pública - a TKCSA se encontra em Santa Cruz, na avenida João XXIII, próximo a uma área residencial com várias comunidades e conjuntos habitacionais. Um dos maiores problemas ambientais associados à produção de ferro e aço é a poluição atmosférica causada por óxido de enxofre $\left(\mathrm{SO}_{\mathrm{x}}\right)$, gás sulfídrico $\left(\mathrm{H}_{2} \mathrm{~S}\right)$, óxidos de nitrogênio $\left(\mathrm{NO}_{x}\right)$, monóxido de carbono (CO), dióxido de carbono $\left(\mathrm{CO}_{2}\right)$, metano $\left(\mathrm{CH}_{4}\right)$, etano $\left(\mathrm{C}_{2} \mathrm{H}_{6}\right)$, material particulado e diferentes hidrocarbonetos orgânicos, como o benzeno. Somente a usina da TKCSA será responsável por um aumento de $76 \%$ nas emissões de $\mathrm{CO}_{2}$ na cidade do Rio de Janeiro (Porto \& Milanez, 2009). Além disso, um dos resíduos mais perigosos da siderurgia é o benzeno, um líquido incolor, volátil e altamente inflamável, que é liberado sob a forma de gás no processo de transformação do carvão em coque. A exposição crônica pode gerar toxidade para o sangue, incluindo anemia (insuficiência de glóbulos vermelhos), leucopenia (insuficiência de glóbulos brancos) e trombocitopenia (insuficiência de plaquetas).

2) Impactos ambientais - em 2007, a TKCSA teve parte de suas obras embargadas pelo Ibama por ter suprimido 4 hectares de mangue (embora tivesse autorização apenas para 2 hectares) para a 
construção de uma ponte (Ibama, 2008). A usina foi objeto também de um inquérito pelo MPF que investiga acusações de crimes ambientais e aponta irregularidades na construção da ponte que teria sido erguida sem a autorização da Secretaria do Patrimônio da União (SPU) (Rodrigues \& Werneck, 2009). Em novembro de 2010 e junho de 2006, o Grupo de Atuação Especial de Combate ao Crime Organizado (Gaeco) do Ministério Público do Estado do Rio de Janeiro ajuizou duas ações penais contra a TKCSA, denunciando por crimes ambientais a empresa e mais três executivos. Segundo as ações, a usina tem gerado poluição atmosférica em níveis capazes de provocar danos à saúde humana, podendo causar doenças de pele, irritação de mucosas e problemas respiratórios (O Globo, 2010; Lima, 2011).

3) Impactos sobre a pesca - boa parte da população da baía de Sepetiba vive atualmente da pesca artesanal, caracterizada por empregar apenas mão de obra familiar e pouca tecnologia. A atividade da pesca, nesse contexto, encontra-se relacionada a um profundo conhecimento tradicional e exerce um forte peso na identidade dessas populações. Desde o início do processo de instalação da usina, esses pescadores passaram a competir com as embarcações utilizadas nas obras e nas dragagens pelo uso do espaço marinho (Villas Boas, 2008). Além disso, por motivos de segurança, no entorno dos empreendimentos se criou uma área de exclusão para a pesca, e a movimentação de pequenas embarcações foi proibida em cerca de 500 metros ao redor da estrutura. A pesca artesanal, por apresentar padrões definidos de territorialidade e utilizar embarcações frágeis e de pequeno porte, encontra enormes dificuldades em reorientar suas atividades para outras áreas e, na baía, será ainda mais intensamente prejudicada, na medida em que estão planejados, no mínimo, mais três portos de grande dimensão.

Além dos impactos negativos causados à região e à população, não se concretizaram os empregos prometidos pela empresa ao se instalar na região. Durante as obras, os empregos eram de baixa qualidade e, não raras vezes, a empresa, por meio de suas terceirizadas, optou por trazer trabalhadores de outras regiões do país para o local. Isso ocasionou um crescimento rápido e desordenado dos municípios vizinhos, acarretando o aumento dos aluguéis, da violência e da prostituição. Em agosto de 2009, foram encontrados trinta trabalhadores de uma terceirizada da TKCSA que viviam em condições 
precárias de higiene e saúde e que estavam há dois meses sem receber seus salários (Pinheiro, 2009).

A promessa de emprego não foi acompanhada de uma análise da sua necessidade e compatibilidade com a população local, bem como da quantidade de postos de trabalho destruídos com a implantação da usina. A falta de qualificação profissional da população da baía de Sepetiba e dos pescadores artesanais os impede de ter acesso aos empregos gerados pela usina. Por isso, para formar seu quadro de funcionários, a TKCSA tem recrutado profissionais em outras empresas siderúrgicas brasileiras. Só da CSN, em Volta Redonda, a TKCSA teria contratado cerca de quatrocentos funcionários, causando até um mal-estar entre as duas empresas no Instituto Aço Brasil, entidade que reúne os fabricantes de aço no país (Valor Econômico, 2010).

Em adição, há denúncias de envolvimento da empresa, no momento de sua instalação, com grupos criminosos da Zona Oeste do Rio de Janeiro (Brasil, 2009a). A Zona Oeste, com destaque para Santa Cruz, Sepetiba, Pedra de Guaratiba e Campo Grande, é área de atuação de grupos de milicianos, grupos armados compostos por agentes do poder público e pessoas cooptadas nas comunidades carentes, que usam a força para dominar uma determinada região e explorar de maneira ilegal as atividades de transporte coletivo, gás, TV a cabo e segurança, entre outras. No relatório da Comissão Parlamentar de Inquérito (CPI) das Milícias, conduzida pela Assembleia Legislativa do Estado do Rio de Janeiro (Alerj), Ignácio Cano define as milícias em relação a cinco eixos principais: controle de um território e da população que nele habita por parte de um grupo armado regular; o caráter coativo desse controle; o ânimo de lucro individual como motivação central; um discurso de legitimação referido à proteção dos moradores e à instauração de uma ordem; e a participação ativa e reconhecida de agentes do Estado (Alerj, 2008).

No mesmo documento, reconhecem-se partes da baía de Sepetiba como área de atuação de grupos milicianos. Desde 2006/7, ouviam-se na região denúncias de que a segurança patrimonial da TKCSA era exercida em parte por funcionários ligados às milícias, que ameaçavam diretamente os pescadores e moradores que se dispunham a usar a voz contra o empreendimento. Essas denúncias foram formalizadas na audiência pública de março de 2009, promovida pela Comissão de Defesa dos Direitos Humanos da Alerj, ${ }^{21}$ como se pode verificar no depoimento de dois pescadores durante

\footnotetext{
${ }^{21}$ Desde a audiência, em consequência das constantes ameaças de morte recebidas, um pescador foi incluído no Programa Federal dos Defensores dos Direitos Humanos da Secretaria Especial dos Direitos Humanos e obrigado a sair do estado (Brasil, 2009).
} 
a audiência: "Quanto à atuação dos senhores (falando com funcionários da empresa), utilizando-se de milícia armada para intimidar pescador, isso é um fato. Vocês usam criminosos para ameaçar pescadores" (Alerj, 2009).

O Estado, de forma geral, apoiou a empresa com financiamento público no valor de R\$2,4 bilhões do Banco Nacional de Desenvolvimento Econômico e Social (BNDES) (Tautz, 2012). Adicionalmente, estudos (Mesentier \& Lima, prelo) sugerem que o empreendimento já tenha recebido cerca de $\mathrm{R} \$ 5$ bilhões em recursos públicos, por meio de financiamento, diferimento de impostos e isenções fiscais.

Além disso, o apoio governamental ao projeto pode também ser verificado na presença de muitas autoridades na cerimônia de inaguração do empreendimento, em particular, do presidente da República na época, Luiz Inácio Lula da Silva, do governador do estado, Sérgio Cabral, e do prefeito do Rio de Janeiro, Eduardo Paes. Nessa ocasião Lula declarou:

[Quero] Dizer para vocês da minha alegria, porque não tem nada mais gratificante para um governante (...) do que concluir um projeto, concluir uma obra. (...) E quero dizer que é um sonho realizado vir aqui concretizar e ver a cara de tanta gente boa que vai levar para casa o pão de cada dia às custas do seu trabalho e do seu suor. (...) É com muito orgulho que eu digo à Thyssen, à Vale, ao Sérgio, ao prefeito e a vocês: muito obrigado, e o Brasil saberá agradecer o que vocês fizeram acontecer neste país hoje. (Brasil, 2010a)

A empresa também realizou doações a órgãos públicos que, de uma forma geral, deveriam exercer papel de fiscalizadores de suas atividades. Segundo documento da ThyssenKrupp, entre seus 'projetos sociais', estavam: um acordo para cooperação técnica com o objetivo de reformar o escritório-sede da Fundação Estadual de Engenharia do Meio Ambiente (Feema), antigo órgão ambiental do estado do Rio de Janeiro (atual Inea, órgão ambiental licenciador e fiscalizador do estado); a negociação com o governo do estado do Rio de Janeiro para a instalação de uma unidade de pronto atendimento em Santa Cruz, bem como a compra de equipamentos e veículos para os bombeiros e para as autoridades portuárias de Itacuruçá (Kroll, Bailer \& Still, 2009).

Embora tenha sido inaugurada em 2010, a TKCSA não tinha licença de operação. A empresa operava assegurada por um Termo de Ajuste de Conduta (TAC) assinado em março de 2012 entre ela mesma e o Inea - sem a presença do Ministério Público estadual. O TAC ampliou o prazo para a obtenção da licença por mais dois anos e estabeleceu que a empresa deveria cumprir 134 pontos como condicionante para a licença, entre eles a realização de um 
sistema de despoeiramento do poço de emergência. Mesmo sem licença e com inúmeros passivos ambientais e sociais, ${ }^{22}$ a Thyssen Krupp vem tentando vender a empresa, e a principal indicada para comprá-la é a Companhia Siderúrgica Nacional (Sant'Anna, 2013).

A TKCSA é parte central da estratégia de crescimento da Vale e da ThyssenKrupp no mercado siderúrgico mundial e vem confirmar, no Brasil, a tendência de transferência de plantas da 'fase quente' da siderurgia para os países em desenvolvimento. A Vale, nesse sentido, vem projetando e implantando progressivamente siderúrgicas para produtos semielaborados no Espírito Santo (Anchieta), Ceará (Pecém) e Rio de Janeiro (Santa Cruz), o que vem produzindo muitos impactos socioambientais e violações de direitos humanos.

\section{Conclusões}

Os casos analisados até aqui demonstram que a ampliação das atividades mineradoras e siderúrgicas no Brasil tem não apenas intensificado passivos e conflitos históricos entre essas atividades e comunidades locais, como tem sido um mecanismo gerador de novas injustiças ambientais nos territórios. Esse argumento tem como base uma breve análise do Mapa de Conflitos, que mostrou que as injustiças ambientais associadas à extração de minérios aparecem em maior quantidade nos estados do Pará e de Minas Gerais, ao passo que as disputas associadas ao beneficiamento dos minérios se concentram no Pará e no Maranhão.

O estudo do mapa também evidenciou a importância da cadeia do ferro e aço na geração de riscos à saúde e injustiças ambientais. Por esse motivo, realizamos um estudo mais detalhado dessa cadeia no Brasil e apresentamos quatro casos envolvendo extração de minério de ferro, seu transporte, produção de ferro-gusa e fabricação de aço.

Contudo, embora sejam emblemáticos, não podemos considerar que os exemplos apresentados resumam a diversidade de questões associadas à expansão da mineração no país. Existem ainda impactos, específicos de outros tipos de mineração, que não abrangemos neste capítulo. Por exemplo, o beneficiamento de vários minérios resulta na geração de grande

\footnotetext{
${ }^{22}$ Além das duas ações penais movidas pelo MPRJ, a TKCSA é objeto de mais de 230 ações civis propostas pela Defensoria Pública, em que moradores cobram à empresa indenização por danos à saúde, e de cerca de nove ações movidas por associações de pescadores por danos morais e perdas causadas à pesca da região em decorrência da instalação da empresa.
} 
quantidade de resíduos altamente tóxicos, como a lama vermelha produzida na transformação da bauxita para a produção de alumínio, e de resíduos radioativos da mineração de urânio voltada para a produção de combustível nuclear. Questões dessa ordem não foram tratadas nos estudos de caso mencionados, ainda que sejam importantes fontes de risco para a saúde da população e do meio ambiente. A discussão sobre seus impactos deve ainda ser aprofundada pela sociedade brasileira.

Nas décadas recentes, o Brasil vem se reposicionando como fornecedor global de commodities minerais, energéticas e agrícolas. Para atender a esse 'novo' papel, movimentos estratégicos têm sido feitos em diferentes frentes e com distintos reflexos sobre a sociedade brasileira. Um deles é a abertura de minas de fosfato, para responder à crescente demanda de fertilizantes químicos para o setor agroexportador. Uma segunda iniciativa é a mineração de urânio para atender à expansão do setor nuclear, em franco processo de expansão com base em um discurso que defende a energia de "baixa emissão de carbono". Além disso, a intensificação da extração de ferro e outros minérios metálicos (por exemplo, bauxita, níquel, cobre e nióbio) tende a aumentar a extração nas minas atuais, como no caso de Carajás, que passa por processo de expansão, e tende também a ampliar ainda mais a busca de território por parte das empresas mineradoras.

Nesse novo contexto, questões que vêm pautando o setor nos anos recentes são a mudança no marco legal da mineração, a regulamentação da mineração em terras indígenas e a expansão da atividade de mineradoras brasileiras para outros países, em especial na América Latina e na África. Conflitos dessa natureza já têm sido identificados em locais como Moçambique, Chile, Argentina e Peru, conforme denunciado durante o I Encontro Internacional dos Atingidos pela Vale (www.atingidospelavale.wordpress.com).

Diante da perspectiva da expansão dos conflitos e injustiças ambientais, torna-se necessária a proposição não apenas de alternativas, mas também a construção, levando em conta o cenário atual, de caminhos de transição para tais alternativas. Com respeito ao uso dos recursos minerais, o debate pode ser feito em quatro níveis.

Em um primeiro nível, é preciso pactuar que a extração e o beneficiamento dos recursos minerais não podem agredir a saúde das pessoas e do meio ambiente. Alguns dos casos apresentados exemplificam o descumprimento da legislação ambiental e trabalhista, bem como o desrespeito às pessoas e às comunidades. Práticas dessa natureza não são aceitáveis, e é fundamental que as cadeias minerais se tornem capazes de contribuir para o desenvolvimento 
do país sem causar sofrimento às pessoas ou destruir nosso patrimônio natural e cultural.

O debate de segundo nível vai além da questão de requisitos de segurança ou controle ambiental, e inclui uma reflexão a respeito do consumo brasileiro dos recursos minerais. Embora uma parte importante da expansão da siderurgia no Brasil tenha ocorrido para atender à demanda internacional, existe a pressão doméstica, que também precisa ser analisada. Nesse contexto, torna-se necessário discutir sobre a intensidade do consumo brasileiro de aço. Por exemplo, aproximadamente $30 \%$ do aço usado no país são transformados em automóveis que engarrafam as cidades e contribuem para o adoecimento das pessoas e para as mudanças climáticas.

Ao mesmo tempo, é importante questionar o atual modelo de produção, uma vez que grande quantidade de aço é desperdiçada nos lixões e ferrosvelhos na forma de embalagens, carros abandonados, eletrodomésticos quebrados e resíduos de demolição. Em parte, esse desperdício ocorre porque, como o modelo produtivo atual não incorpora ao preço da produção os danos ambientais e o adoecimento de trabalhadores e da sociedade, considera-se 'mais barato' produzir aço novo à base de minério de ferro do que reciclar o aço existente. Essa conta não é, a longo prazo, vantajosa nem para a nossa sociedade nem para o planeta. Diante disso, uma discussão necessária envolveria a avaliação de formas de incorporar ao preço do aço 'virgem' todas as externalidades negativas - como denominam os economistas - que sua produção causa, de forma a estimular a reciclagem do material desperdiçado pela sociedade.

Para o debate de terceiro nível, é importante examinar a participação do Brasil no mercado global como fornecedor de produtos minerais e metálicos de baixo valor agregado, participação essa que poderia ser avaliada como uma inserção inadequada do país dentro de um comércio internacional injusto. Nesse sentido, a sociedade brasileira deve começar a refletir sobre as vantagens e desvantagens de se especializar na exportação de minérios, produtos semiacabados e commodities de forma geral. Apesar de serem geradores de divisas, esses produtos são intensivos em poluição e no uso de recursos naturais, muitos dos quais não renováveis. Além disso, essa especialização aumenta a dependência do país por produtos de maior valor agregado e intensivos em conhecimento.

A discussão de quarto nível vai além da escolha sobre o 'grau de verticalização' desejável para a cadeia de ferro e aço no país. A siderurgia é por natureza uma atividade intensiva em recursos naturais e poluição. Ela teve 
um papel importante para o crescimento econômico de países hoje altamente industrializados, como Inglaterra e Alemanha. Contudo, a trajetória desses países também demonstra como essas economias, mesmo fabricando produtos de alto valor agregado, comprometeram seriamente a qualidade ambiental de seus territórios e a saúde de parcela significativa de sua população. A experiência desses países deveria ser levada em consideração pela sociedade brasileira ao refletir até que ponto é desejável ampliar tais atividades em sua economia.

Acreditamos que a sociedade brasileira seja capaz de criar um modelo próprio de produção e consumo que, em vez de intensivo em recursos naturais, tenha por base a criatividade de seu povo, o desenvolvimento das pessoas, a diversidade sociocultural e a proteção ao meio ambiente. Tal modelo, porém, ainda precisa ser construído, e o caminho para alcançá-lo necessita ser traçado. E para tal construção são necessários o diálogo e a união de todos aqueles que desejam para o Brasil um desenvolvimento mais socialmente justo e ambientalmente sustentável. 


\section{Referências}

ACSELRAD, H. (Org.). Conflitos Ambientais no Brasil. Rio de Janeiro: Relume Dumará, Fundação Heinrich Böll, 2004.

ALMEIDA, A. W. B. Refugiados do desenvolvimento: os deslocamentos compulsórios de índios e camponeses e a ideologia da modernização. Travessia - Revista do Imigrante, 25, ano XX: 30-35, 1996.

ALVES, E. J. P.; SANT'ANA JR., H. A. \& MENDONÇA, B. R. Projetos de desenvolvimento, impactos socioambientais e a reserva extrativista do Taim. Ciências Humanas em Revista, 5 (n. especial): 29-40, 2007.

ANGLO AMERICAN. Quem somos. Site. Disponível em: <www.angloamerican.com.br/ about-us/historia.aspx?sc_lang=pt-PT>. Acesso em: jul. 2012.

ASSEMBLEIA LEGISLATIVA DO ESTADO DO RIO DE JANEIRO (ALERJ). Comissão de Defesa dos Direitos Humanos e Cidadania. Relatório final da Comissão Parlamentar de Inquérito Destinada a investigar a ação de milícias no âmbito do estado do Rio de Janeiro. Rio de Janeiro: Alerj, 2008. Disponível em:<www.nepp-dh.ufrj.br/relatorio_milicia.pdf>. Acesso em:jun. 2012.

ASSEMBLEIA LEGISLATIVA DO ESTADO DO RIO DE JANEIRO (ALERJ). Comissão de Defesa dos Direitos Humanos e Cidadania. Ata da segunda audiência pública. Rio de Janeiro: Alerj, 19 mar. 2009.

ASSIS, W. S. \& CARNEIRO, M. D. S. Uso del carbón vegetal como fuente de energía para el Parque Siderúrgico de Carajás: controversias ambientales, sociales y económicas. In: TONI, F. \& PORRO, R. (Orgs.). Energía, Medio Ambiente y Desarrollo en la Amazonía. Madrid: Editorial Académica Española, 2012.

BRASIL. Lei n. 8.630 de 25 fev. 1993. Disponível em: <www.planalto.gov.br/ccivil_03/leis/18630. htm>. Acesso em: jun. 2012.

BRASIL. Presidência da República. Secretaria Especial dos Direitos Humanos. Programa de Proteção aos Defensores dos Direitos Humanos. Brasília: SEDH, 2009a.

BRASIL. Ministério de Minas e Energia. Secretaria de Geologia, Mineração e Transformação Mineral. Relatório técnico 83: reciclagem de metais no país. Brasília: Secretaria de Geologia, Mineração e Transformação Mineral, 2009b.

BRASIL. Presidência da República. Discurso do Presidente da República, Luiz Inácio Lula da Silva, na cerimônia de inauguração da ThyssenKrupp CSA Siderúrgica do Atlântico. Rio de Janeiro, 18jun. 2010a. Disponível em: <www.biblioteca.presidencia.gov.br/ex-presidentes/luizinacio-lula-da-silva/discursos/2o-mandato/2010/1o-semestre/18-06-2010-discurso-do-presidenteda-republica-luiz-inacio-lula-da-silva-na-cerimonia-de-inauguracao-da-thyssenkrupp-csasiderurgica-do-atlantico/view>. Acesso em: 9 ago. 2013.

BRASIL. Ministério do Desenvolvimento Indústria e Comércio Exterior. Site. Portal Aliceweb. Disponível em: <www.aliceweb.desenvolvimento.gov.br>. Acesso em: 4 nov. 2010b.

BRIGATTO ALBINO, U. Relatório de perícia ambiental: Imperatriz, 2007. Disponível em: <www. justicanostrilhos.org/nota/1117>. Acesso em: 11 jul. 2013.

BÜHLER, R. R. A siderurgia no Brasil e no mundo. In: SEMINÁRIO SIDERURGIA, 2007, Porto Alegre. Anais... Porto Alegre: Instituto Brasileiro de Siderurgia, 2007.

CASTRO H.; GIANNASI, F. \& NOVELLO, C. A luta pelo banimento do amianto nas Américas: uma questão de saúde pública. Ciência E Saúde Coletiva, 8(4): 903-911, 2003. 
CONSELHO REGIONAL DE ECONOMIA (CORECON-RJ). Entrevista com o secretário de Desenvolvimento Econômico, Energia, Indústria e Serviços do Estado do Rio de Janeiro, Júlio Bueno. Rio de Janeiro: Corecon, 2009. Disponível em: <www.corecon-rj.org.br/entrev_det. asp?Id_ent=46>. Acesso em: 10 jun. 2012.

DEFENSORIA PÚBLICA DO ESTADODE SÃO PAULO. Ação civil pública em face do Município de Taubaté/SP, da empresa Votorantim Celulose e Papel S.A. e do Estado de São Paulo, 2010. Disponível em: <www.defensoria.sp.gov.br/>. Acesso em: 9 ago. 2013.

DEPARTAMENTO NACIONAL DE PRODUÇÃO MINERAL (DNPM). Economia mineral do Brasil - 2009. Brasília: Departamento Nacional de Produção Mineral, 2009.

DEPARTAMENTO NACIONAL DE PRODUÇÃO MINERAL (DNPM). Maiores arrecadadores CFEM. Brasília: Departamento Nacional de Produção Mineral, 2010. Disponível em: <www. dnpm.gov.br/conteudo.asp?IDSecao=555\&IDPagina=51>. Acesso em: 5 dez. 2010 .

FORUM CARAJÁS. Site. Disponível em:<www.forumcarajas.org.br>. Acesso em: 15 fev. 2012.

FUNDAÇÃOOSWALDOCRUZ/ FEDERAÇÃODOSÓRGÃOS PARA ASSISTÊNCIA SOCIAL E EDUCACIONAL (FIOCRUZ/FASE). Mapa de Conflitos Envolvendo Injustiça Ambiental e Saúde no Brasil, 2009. Disponível em: <www.conflitoambiental.icict.fiocruz.br>. Acesso em: 9 dez. 2010.

GONÇALVES, G. Baía de Sepetiba atrai R\$ 38 bilhões em Investimentos. O Estado de S. Paulo, São Paulo, 11 jul. 2010.

INSTITUTO BRASILEIRO DE SIDERURGIA (IBS). Anuário estatístico 2003. Rio de Janeiro: Instituto Brasileiro de Siderurgia, 2003.

INSTITUTO BRASILEIRO DE SIDERURGIA (IBS). Anuário estatístico 2007. Rio de Janeiro: Instituto Brasileiro de Siderurgia, 2007.

INSTITUTO BRASILEIRO DE SIDERURGIA (IBS). Site. Rio de Janeiro: Instituto Brasileiro de Siderurgia, 2008. Disponível em: <www.ibs.org.br/siderurgia_historia_brasil1.asp $>$. Acesso em: 8 jan. 2008.

INSTITUTO BRASILEIRO DE SIDERURGIA (IBS). Anuário estatístico 2009. Rio de Janeiro: Instituto Brasileiro de Siderurgia, 2009.

INSTITUTO BRASILEIRO DO MEIO AMBIENTE E DOS RECURSOS NATURAIS (IBAMA). Diagnóstico do setor siderúrgico nos estados do Pará e do Maranhão. Brasília: Instituto Brasileiro do Meio Ambiente e dos Recursos Naturais Renováveis, 2005.

INSTITUTO BRASILEIRO DO MEIO AMBIENTE E DOS RECURSOS NATURAIS (IBAMA). Termo de embargo e interdição n. 487354/C. Processo 02022.000010/2008-88. IBAMA/MMA GEREX I/RJ. Rio de Janeiro, 3 jan. 2008.

INSTITUTO DE POLÍTICAS ALTERNATIVAS PARA O CONE SUL (PACS). Até quando a TKCSA terá licença para produzir 'chuva de prata' em Santa Cruz? 26 fev. 2013. Disponível em: $<$ www.pacs.org.br/2013/02/26/ate-quando-a-tkcsa-tera-licenca-para-produzir-chuva-de-prataem-santa-cruz/>. Acesso em: jul. de 2013.

JUSTIÇA NOS TRILHOS. A Vale e a crise siderúrgica em Açailândia, 2010a. Disponível em: $<$ www. justicanostrilhos.org/nota/596 > . Acesso em: 2 dez. 2010.

JUSTIÇA NOS TRILHOS. Vale recebeu de BNDES quase 8 bilhões em três anos. Disponível em: $<$ www.justicanostrilhos.org/nota/502>. Acesso em: 5 set. 2010b.

KROLL, D.; BAILER, K. \& STILL, G. Ausschuss für Wirtschaftliche Zusammenarbeit und Entwicklung. Berlin: Deutscher Bundestag, 2009. 
LIMA, K. CSA é novamente denunciada no RJ por crime ambiental. Estado de S. Paulo, 2011. Disponível em: <www.economia.estadao.com.br/noticias/neg\%C3\%B3cios,csa-e-novamentedenunciada-no-rj-por-crime-ambiental,70717,0.htm>. Acesso em: jul. 2013.

MARANHÃO. Decreto estadual n. 20.727 de 23 ago. 2004. Reformula a área do Distrito Industrial de São Luís - Disal, aprovado pelo decreto estadual n. 18.842 de 17 de julho de 2002 e dá outras providências. Diário Oficial do Estado do Maranão, 2004a.

MARANHÃO. Decreto estadual n. 20.781 de 29 set. 2004. Declara de utilidade pública, para todos os fins legais, a área do Sub-Distrito Industrial Siderúrgico, situada no Município de São Luís. Diário Oficial do Estado do Maranhão, 2004b.

MENDONÇA, B. Cajueiro: entre as durezas da vida e do ferro, no tempo do aço, 2006. Monografia, São Luís: Universidade Federal do Maranhão.

MESENTIER, A. \& LIMA, R. TKCSA: um paraíso fiscal em Santa Cruz. Rio de Janeiro: Instituto de Políticas Alternativas para o Cone Sul (Pacs), no prelo.

MIRANDA, A. C. P.; MAIA, M. R. S. \& GASPAR, R. B. Entrevista com Alberto Cantanhede, o Beto do Taim. In: SANT'ANA JR., H. A. et al. (Orgs.). Ecos dos Conflitos Socioambientais: a Resex de Tauá. São Luís: EdUFMA, 2009.

O GLOBO. Companhia Siderúrgica do Atlântico é denunciada pelo MPRJ por crimes ambientais. O Globo, Rio de Janeiro, 2 dez. 2010. Disponível em: <www.oglobo.globo.com/economia/ mat/2010/12/02/companhia-siderurgica-do-atlantico-denunciada-pelo-mprj-por-crimesambientais-923172982.asp>. Acesso em: dez. 2010.

OBSERVATORIO DE CONFLICTOS MINEROS EN AMÉRICA LATINA (OCMAL). Projeto Minas-Rio, da MMX, inicia em uma unidade de conservação e gera conflitos, 2009. Disponível em: <www.olca.cl/ocmal/ds_conf.php?nota=Conflicto\&p_busca=134>. Acesso em: jun. 2012.

ORGANIZAÇÃO DAS NAÇÕES UNIDAS PARA A EDUCAÇÃO, A CIÊNCIA E A CULTURA (UNESCO). Biosphere reserve information: Espinhaço range, 2006. Disponível em: <www. unesco.org $/ \mathrm{mabdb} / \mathrm{br} / \mathrm{brdir} /$ directory/biores.asp? mode=all\&code=BRA+06 $>$. Acesso em: 7 jan. 2011.

PINHEIRO, A. Trabalhadores sem salários e com uma refeição por dia. O Dia, Rio de Janeiro, 13 ago. 2009.

PORTAL ECODEBATE. Siderúrgicas são multadas em R $\$ 500$ milhões por uso de carvão ilegal, 2005. Disponível em:<www.ecodebate.com.br/2005/10/21/siderurgicas-sao-multadas-em-r-500milhoes-por-uso-de-carvao-ilegal>. Acesso em: 7 jan. 2011.

PORTO, M. F. \& MILANEZ, B. Parecer técnico sobre o relatório de impacto ambiental da usina da Companhia Siderúrgica do Atlântico (CSA). Rio de Janeiro: Fundação Oswaldo Cruz (Fiocruz), jul. 2009.

RODRIGUES, A. \& WERNECK, F. Usina da ThyssenKrupp no Rio é alvo de investigação do MPF. O Estado de S. Paulo, São Paulo, 30 abr. 2009.

SANT'ANNA, A. ThyssenKrupp provavelmente venderá CSA para CSN. Exame, 5 maio 2013. Disponível em: <http://exame.abril.com.br/negocios/aquisicoes-fusoes/noticias/thyssenkruppprovavelmente-vendera-csa-ara-csn>. Acesso em: jul. 2013.

SÃO LUÍS. Lei n. 3.253 de 29 dez. 1992. Dispõe sobre o zoneamento, parcelamento, uso e ocupação do solo urbano e dá outras providências. Disponível em: <www.gepfs.ufma.br/legurb/ LEI\%203253.pdf $>$. Acesso em: 2 set 2009.

SINDICATO DAS INDÚSTRIAS DO FERRO NO ESTADO DE MINAS GERAIS (SINDIFER). Anuário 2007. Disponível em: <www.sindifer.com.br/Anuario_2007.html>. Acesso em: 16 abr. 2008. 
TAUTZ, C. O Contrato do BNDES com a TKCSA. Mais Democracia, 3 out. 2012. Disponível em: $<$ www.maisdemocracia.org.br/blog/2012/10/03/o-contrato-do-bndes-com-a-tkcsa/>. Acesso em: julho de 2013.

VALLE, R. (Dir.). Conceição: guarde nos olhos (Partes I, II, III). s.l.: Camarela Studios, 2009. Disponível em: <www.youtube.com>. Acesso em: 20 jul. 2012.

VALOR ECONÔMICO. CSN diz que ThyssenKrupp adotou ação hostil no país. Valor Econômico, São Paulo, 23 ago. 2010.

VILLAS BOAS, B. Dragagens e circulação de navios tiram o ganha-pão dos pescadores. O Globo, Rio de Janeiro. Economia, 10 ago. 2008.

WORLD STEEL ASSOCIATION. World Steel in Figures. Brussels: World Steel Association, 2009. WORLD STEEL ASSOCIATION. Steel Statistical Yearbook 2009. Brussels: World Steel Association, 2010. 


\title{
6
}

\section{Capitalismo e Energia: alguns mecanismos básicos dos conflitos e das injustiças sofridas pelo povo brasileiro ${ }^{1}$}

\author{
Arsênio Oswaldo Sevá Filho
}

\begin{abstract}
ste capítulo tem como foco a identificação de alguns mecanismos que permitem explicar e avaliar os riscos e consequências sociais e ambientais das principais atividades de produção e uso de combustíveis e de eletricidade. Inicialmente, definimos os conceitos teóricos e técnicos utilizados na discussão acerca do sistema capitalista e da energia; em seguida, recapitulamos as situações locais e regionais mais representativas das atividades relacionadas aos combustíveis fósseis (carvão, petróleo e gás) e às usinas termelétricas e hidrelétricas. Muitas dessas situações são conflituosas e podem ter as suas fichas descritivas consultadas no Mapa de Conflitos Envolvendo Injustiça Ambiental e Saúde no Brasil (ou Mapa de Conflitos). ${ }^{2}$
\end{abstract}

\section{Para Entender os Conflitos: capitalismo e luta política}

Vivemos no Brasil do século XXI, uma etapa bem definida do capitalismo. Esse sistema de produção e de consumo tem como base a propriedade privada dos meios e instrumentos de produção e a busca incessante por lucro e poder por parte dos donos do capital.

\footnotetext{
${ }^{1}$ Em virtude dos problemas de saúde do autor por ocasião da produção do livro, a versão final deste capítulo foi aprovada por Marcelo Firpo Porto.

${ }^{2}$ Disponível em: <www.conflitoambiental.icict.fiocruz.br $>$.
} 
Essa busca se concretiza por meio de alguns mecanismos principais, que fazem parte da história econômica e social dos últimos séculos: a expropriação de todos os bens comuns e dos recursos que pertencem aos grupos mais pobres (ou são utilizados por eles) e mais desorganizados da sociedade; e a transformação desses grupos, de um lado, em proletários - uma grande massa desempregada ou subempregada - e, de outro, em assalariados formalmente vendedores de sua força de trabalho no mercado de trabalho.

Sob o regime capitalista, o chamado 'desenvolvimento' deve ser entendido como uma trajetória que evolui junto com a acumulação de capital nas mãos dos capitalistas. Essa é uma das principais manobras ideológicas do desenvolvimentismo: a apologia do benefício para todos (a melhoria, o progresso do país) não pode escancarar e tornar visível o mecanismo de concentração de riqueza (acumulação privada).

O capital se acumula por meio da exploração do trabalho, ou seja, pela extração de sobretrabalho dos assalariados e pelos diferenciais entre os ganhos de produtividade (maiores) e os aumentos (menores) de salários, mas também pela poderosa alavanca da acumulação primitiva, que ainda está em vigor.

Geralmente, o conceito de acumulação primitiva designa processos históricos, ocorridos nos séculos XVIII e XIX, quando as terras comuns europeias foram cercadas pelos grandes proprietários, pelas empresas de mineração, por agências de Estado. Os chamados 'homens comuns', do povo, sem títulos de propriedade, foram separados de seus meios sociais de produção e do acesso às suas condições básicas de reprodução. O cercamento das terras onde moravam e trabalhavam foi uma precondição para a proletarização e/ou para o assalariamento, e quase sempre esse cercamento foi uma via certeira para a pobreza e a emigração.

Essa alavanca da acumulação nunca acabou, foi se deslocando no interior dos países capitalistas, de uma região a outra, tomando novas formas de expropriação de outros bens comuns, como as matas, os litorais, os rios (De Angelis, 2001). Em novos países, como os Estados Unidos, povos nativos foram exterminados ou obrigados a morar em reservas limitadas, para que os colonos pudessem avançar com a agricultura capitalista e com a exploração madeireira, para que os 'empreendedores' consolidassem as ferrovias, a mineração, a grande pecuária - suprindo os frigoríficos - e, depois, para que implantassem os poços e dutos de petróleo e as hidrelétricas com suas represas cada vez maiores.

Os imperialismos se tornaram bem conhecidos nos séculos XIX e XX, quando se instrumentalizaram tais surtos de acumulação primitiva em 
localidades consideradas estratégicas na África, na Ásia, na Oceania. Em especial, nessa época, se reconquistaram as Américas do centro e do sul onde as terras comuns dos ancestrais astecas, maias, quéchuas, aimarás e de tantos outros povos nativos, bem como as terras públicas desses países recém-independentes foram e ainda são objeto de apropriação violenta e institucionalizada por parte das empresas capitalistas, muitas vezes mediadas pelo Estado e pelas elites locais.

É nessa mesma perspectiva histórica e política que devemos entender como, no Brasil de hoje, numerosos grupos de populações locais e regionais têm sido espoliados e injustiçados por alguns dos mais poderosos setores da indústria moderna: aqueles que produzem e distribuem combustíveis e eletricidade. A espoliação que sofrem esses brasileiros, não somente os grupos locais, mas toda a população trabalhadora e contribuinte, é continuação do colonialismo que nos definiu séculos antes, e é o mesmo ciclo de espoliação que castiga os nossos vizinhos na América do Sul e na América Central.

Uma parte do mecanismo geral de acumulação de capital e de poder se dá hoje pela via da espoliação, o que é bem explicado, entre outros, pelo geógrafo norte-americano David Harvey (2005): os ativos econômicos e as infraestruturas de um país são privatizados a baixo preço, desvalorizados, como se deu no Brasil com a aquisição dos ativos estatais das empresas de mineração como a Vale, das siderúrgicas como a Companhia Siderúrgica Nacional (CSN), a Companhia Siderúrgica Paulista (Cosipa), a Usiminas, das empresas de telefonia, e com as concessões de rodovias e de serviços de águas e esgoto. Por sua vez, os recursos valiosos, como a água (e a possibilidade de irrigação), os minérios, as fontes de energia e de madeira, o patrimônio genético, os locais especiais como os estuários dos rios, as lagoas piscosas e os pesqueiros marinhos são conquistados de modo repressivo, com violência contra os grupos humanos que residiam próximo aos locais de interesse capitalista.

O cercamento da terra prossegue por meio de distintos rearranjos fundiários desencadeados pela expansão do agronegócio (soja, milho, pastagens), das minerações, das represas de hidrelétricas, das monoflorestas industriais (eucaliptais, pinheirais, canaviais).

O recente surto da indústria petrolífera, típico da era neoliberal, em terras argentinas, peruanas, equatorianas, colombianas e bolivianas atinge moradores e nativos, que enfrentam poderosas empresas petroleiras - uma das principais é a multinacional de origem brasileira, a Petrobras, que nesses locais age por meio de empresas subsidiárias e sócias (Leroy \& Malerba, 2004). 
No próprio território brasileiro, os problemas são similares e envolvem não apenas a Petrobras, mas várias outras que começaram a atuar no país justamente na década de 1990, período em que o governo federal propiciou a sua entrada nas licitações de novas áreas a explorar.

O financiamento desses surtos de ampliação capitalista é muito peculiar e deve ser levado em conta para se compreender as consequências sociais. Hidrelétricas, mineradoras, siderúrgicas, celulose, álcool, refinarias são projetos muito caros; cada unidade de produção exige alguns bilhões de reais, e as grandes hidrelétricas exigem dezenas de bilhões.

Mobilizar recursos financeiros dessa ordem resulta de uma estratégia também muito peculiar: cada projeto tem de ser criado como se fosse uma árvore, desde a semente e a muda. Sua concretização em todo momento deve ser considerada 'irreversível' e, para isso, os seus apoiadores e idealizadores precisam reduzir os riscos políticos, identificando os resistentes e conseguindo dobrá-los ou eliminá-los. Para tanto, esses promotores dos investimentos costumam costurar apoio em várias instâncias, desde os grupos locais atingidos, os vizinhos, os jornais e rádios, até prefeitos, parlamentares e governadores. Muita coisa, então, explica-se pelas relações estreitas, e às vezes secretas, entre os executivos e gerentes das corporações privadas e os homens da administração pública: os funcionários e togados da Justiça, os que atuam no fisco, nas aduanas, nos serviços e obras públicas, nas agências ambientais e trabalhistas, e, novamente, os eleitos do parlamento.

Por tais razões, os grupos locais de moradores que resistem a essas investidas, na realidade, lutam contra o poderio, a soberania empresarial. Sua luta é por sobrevivência elementar, porque não querem ser expropriados, empobrecidos, mas também é por direitos políticos no país onde vivem. Uma luta, afinal, pela democracia.

\section{Explicitando os Conceitos: fontes e usos de energia}

A palavra 'energia', em português, pode expressar distintos significados e conotações em diferentes setores da sociedade. Tantas vezes, já ouvimos ou lemos o termo 'energia' como sinônimo de 'energia humana'. Os humanos são também máquinas termodinâmicas complexas, cuja temperatura se mantém geralmente entre os 36 e $37^{\circ} \mathrm{C}$, mesmo quando submetidos a temperaturas externas bem inferiores ou superiores. De fato, somos máquinas que fazem muitos esforços mecânicos, com mais ou menos força, mais ou menos potência. Outros usam a mesma palavra 'energia', ou seus adjetivos correlatos mais comuns, com sentido psicológico ou sociológico: um pai 
teria mais energia à medida que fosse capaz de exercer controle sobre os filhos ou a família; um governante também seria mais enérgico à medida que fosse severo, firme.

Em discussões acadêmicas sobre o tema, o conceito 'energia' abrange todas as formas e naturezas da energia física, que pode ser mecânica, térmica, química, elétrica, nuclear, magnética e eletromagnética, esta em várias faixas de radiação, inclusive a luz que conseguimos enxergar. Essa diversidade das formas de energia física, se estudada com profundidade como o fazem as ciências (física e química), exige o domínio e a aplicação de um grande conjunto de ferramentas teóricas e empíricas.

Para simplificar, abordaremos aqui algumas das formas usuais da energia que a sociedade utiliza amplamente, a começar pelos 'combustíveis', ou seja, materiais que são deliberadamente queimados, em busca do calor que sua queima fornece-ou pode fornecer (conceito térmico da energia). Em seguida, falaremos da energia como 'força motriz', capacidade de realizar trabalho mecânico (exatamente o conceito mecânico de energia) e da 'corrente elétrica', uma das formas da energia elétrica.

Destacamos as três etapas lógicas do percurso: 1) fontes de energia; 2) conversores de energia: aparelhos, máquinas ou dispositivos que permitem converter uma forma de energia em outra. Exemplos: uma lâmpada comum que converte eletricidade em calor da resistência, do qual uma parte é convertida em luz; um motor que transforma eletricidade em energia de rotação de um eixo, ou, ao contrário, um gerador que transforma a energia mecânica de um eixo em eletricidade; 3) usos finais da energia: a parte que nos interessa como usuários, a luz, o calor, o movimento.

\section{As diversas fontes de energia}

A crosta terrestre e sua atmosfera têm muita vida - um conjunto que resulta da energia interna, que vem de dentro do planeta, onde o núcleo se funde lentamente, e de uma grande quantidade de energia solar, que vem de fora. O planeta, assim, vai se tornando um campo de trocas energéticas permanentes, crescentes.

Por meio de quais fontes, então, podemos obter as formas de energia que utilizamos? Não são muitas, de fato, mas são estas as possibilidades existentes até aqui e que têm sido 'aproveitadas' pelas sociedades humanas: 1) o calor e a luz do Sol, em parte, convertidos na camada atmosférica do planeta, por sua vez, também aquecida pelo seu calor interno; 2) as forças gravitacionais do sistema solar, da Terra e da Lua, as quais, de forma combinada com a primeira 
fonte, origina o ciclo de evaporação da água superficial, formação e transporte de nuvens, trocas de calor entre camadas da atmosfera, ventos, condensação das águas das chuvas. Ao mesmo tempo, por causa do aquecimento e resfriamento diferenciados das porções distintas dos mares e dos oceanos, as trocas térmicas mantêm a circulação das enormes correntes marinhas, de importância vital para o equilíbrio geral do planeta e da vida aquática. Assim, devemos compreender a biosfera e a atmosfera como verdadeiras 'máquinas termodinâmicas', uma argumentação utilizada em várias obras científicas, como no compêndio italiano Pianeta in Prestito: energia, entropia, economia (Tronconi et al., 1991); 3) a energia química, contida nas moléculas orgânicas, mais as energias de ligação química e atômica presentes nos elementos e compostos inorgânicos.

Para o homem e seu milenar espírito prático, o que realmente conta é: "afinal, onde tais fontes se encontram? São acessíveis?". Caso essas fontes venham a ser aproveitadas, ou caso se pretenda aproveitá-las, deve-se resolver como ter acesso a elas. E, então, caberá sempre a dúvida sobre o seu horizonte de utilização, sobre a sua durabilidade. A pergunta é sempre esta: se forem aproveitadas com esta ou com aquela intensidade e neste ou naquele local, por quanto tempo essas fontes naturais de energia estarão disponíveis? Para termos boas respostas para questões tão amplas e cruciais, é necessário termos em mente alguns mecanismos básicos da física e da dinâmica planetária e aplicá-los ao nosso caso. ${ }^{3}$

Os materiais orgânicos e de origem orgânica são fontes de energia que se manifestam de modos bem distintos: a sua 'digestão', oxidação e processamento como alimento propiciam um fluxo de calor para o corpo que está digerindo, para o meio no qual se dá a oxidação. Porém, eles podem ser queimados como combustíveis, pois, dependendo de seu teor de umidade e de seu estado de agregação, pegam fogo ou podem alimentá-lo, gerando calor de modo intencional, controlado (combustão) ou não (incêndio).

Em tais casos, não se pode contar com 'milagres' da termodinâmica: para se obter bons combustíveis à base de matérias-primas naturais, vivas ou inorgânicas, gasta-se uma considerável quantidade de energia. Deve-se 'purificar' uma pedra que contém carvão mineral para que se concentrem os compostos de carbono $(\mathrm{C})$ e hidrogênio $(\mathrm{H})$ que queimam bem (os hidrocarbonetos $\mathrm{C}_{\mathrm{x}} \mathrm{H}_{\mathrm{y}}$ e o gás hidrogênio) e para que se descartem os que não queimam, por exemplo, os que geram cinzas. Um hidrocarboneto gasoso

\footnotetext{
${ }^{3}$ Para maior detalhamento, ver Sevá e colaboradores (1995) e Sevá Filho (2006).
} 
como o metano natural ou mesmo um álcool leve - por exemplo, o etanol pode servir de base para se obter o hidrogênio. Porém, há uma enorme gasto de energia para se quebrar as ligações de um metano $\left(\mathrm{CH}_{4}\right)$ ou de um etanol $\left(\mathrm{C}_{2} \mathrm{H}_{50}\right)$ e se obter dois hidrogênios $\left(\mathrm{H}_{2}\right)$. De modo similar, pode-se obter o hidrogênio, mas é necessário destilar e purificar muito bem a água e, depois, gastar ainda uma enorme soma de eletricidade para, a partir de uma molécula de $\mathrm{H}_{2} \mathrm{O}$, se obter uma de $\mathrm{H}_{2}$.

Tampouco se podem esperar milagres da química: no ar, além do oxigênio $\left(\mathrm{O}_{2}\right)$ que vai queimar, existe $78 \%$ de gás nitrogênio $\left(\mathrm{N}_{2}\right)$. Qualquer queima, desde um palito de fósforo, um pequeno isqueiro até um potente maçarico de $\mathrm{H}_{2}$, vai aquecer o ar entorno, provocando oxidação térmica do $\mathrm{N}_{2}$ para $\mathrm{NO}, \mathrm{N}_{2} \mathrm{O}$ ou $\mathrm{NO}_{2}$.

A precaução geral é identificar os processos em curso para se desviar a tempo de argumentações ilusórias e falsas expectativas. Para isso, a lógica ajuda ao interligar sempre os usos, os conversores e as fontes de energia. Não se podem enfocar exclusivamente os usos finais (por exemplo, se precisamos de calor para o preparo de alimentos), se não estão bem detalhados o funcionamento e as características dos conversores usados (o nosso fogão ou forno queimando gás liquefeito de petróleo - GLP -, aquele do botijão -; o forno onde o objeto é bombardeado com radiações bem curtas ou 'micro-ondas') e as características dos conversores que se podem usar (fogão ou forno a lenha; panela colocada num concentrador de feixe de luz solar). Da mesma forma, não adianta se especular sobre esta ou aquela fonte de energia sem se refletir bem sobre os usos previstos da energia proveniente da fonte em questão e de outras possíveis. Para se atingir o mesmo fim, pode haver várias rotas.

\section{Os Aproveitamentos da Biomassa e Matérias Orgânicas para Obtenção de Combustíveis}

O termo 'biomassa' pode abranger os derivados recentes de organismos vivos utilizados como combustíveis ou para a produção deles, mas muitos autores consideram biomassa, em termos de produção de energia, apenas para materiais derivados da vida vegetal e considerados renováveis em período inferior a cem anos. Dessa forma, o petróleo, carvão mineral e o xisto betuminoso, apesar de derivarem da vida vegetal, não estão incluídos, já que resultam de transformações na natureza que levaram milhões de anos. A seguir apresentamos algumas fontes de biomassa e materiais orgânicos para a geração de combustíveis. 
1) A lenha, a galharia e os resíduos são usados in natura, ainda úmidos ou após a secagem, ou, então, podem ser carvoejados - a queima abafada elimina a umidade e as partes voláteis da madeira -, obtendo-se o carvão vegetal: uma das melhores substâncias para queima em fogões, fornos e caldeiras.

2) A cera de abelhas, os óleos e as resinas vegetais podem ter outros usos nobres, mas também queimam bem; as cascas de cocos, de nozes, de árvores, que são mais fibrosas, secas e mais densas que os demais vegetais, podem se tornar um carvão vegetal ainda melhor que o de madeira.

3) Os resíduos agrícolas (fibras, ramas, podas de fruteiras, sabugos) e os resíduos do processamento de madeira (serragem, cavacos, mais os 'licores' da extração de celulose), e também os vários tipos de gordura animal, de leões marinhos e focas, de peixes, porcos, javalis, ou o óleo de baleia, foram historicamente muito usados para alimentação, aquecimento e iluminação.

4) Os álcoois de vegetais, como milho, cana, arroz, mandioca, cereais, e de frutos (o mais conhecido é o vinho de uva) são feitos geralmente para beber, mas também podem ser purificados para servir de combustíveis líquidos. Os seus bagaços, cascas e tortas da moagem e prensagem podem ser queimados ou virar adubo; além disso, é possível aproveitar como combustíveis os gases de fermentação desses mesmos processos de fabricação de bebidas, e os da biodigestão de borras industriais, de esgotos humanos e de dejetos animais.

Descrevemos, a seguir, as substâncias que os homens têm utilizado em razão da presença de compostos de carbono, hidrogênio e enxofre em diversos materiais fossilizados: os sólidos e entranhados de líquidos e gases encontrados na terra, no subsolo. Ou seja, os homens vieram resolvendo sua demanda de luz e de calor também por meio da biomassa do passado: fontes não renováveis de substâncias combustíveis.

1) A turfa ou 'terra combustível', cinza escura, quase preta, ou 'terra vegetal', e os solos e rochas ricos em carbono: o linhito, ou carvão marrom, o carvão de pedra (hulhas, de cor preta) e os xistos betuminosos (rochas impregnadas de óleo), ou seja, todos que contêm hidrocarbonetos de origem fóssil têm de ser 'minerados', extraídos do subsolo, e somente são aproveitados como combustíveis sólidos depois de 'beneficiados', ou seja, 
processados industrialmente para concentrar os elementos carbono e hidrogênio. A grande utilização desses combustíveis sólidos veio exatamente para compensar a relativa falta de lenha nas imediações das áreas industriais. Teve um impulso extraordinário quando se começou, nos séculos XVIII e XIX, a usar muitas caldeiras para produzir o vapor que acionava as primeiras máquinas a pistão; uma boa parte de tais das caldeiras foi empregada para movimentar as minas e a própria economia carbonífera e para alimentar os trens e as embarcações a vapor.

2) Alcatrão e coque são obtidos a partir do carvão mineral, por meio de processos semelhantes ao carvoejamento, ou seja, cozinhar em queima abafada o minério e recuperar os gases desta queima. Desses gases, após o resfriamento e a condensação se obtêm uma mistura de hidrocarbonetos líquidos e, entre eles, o óleo viscoso chamado de alcatrão e uma mistura de naftas que é utilizada também para fazer querosene e gasolina. A parte sólida resultante desse processo é o coque, um carvão com maior concentração de carbono, mais leve e seco, que servirá para muitos fins na indústria, principalmente para a fundição de metais.

3) A parte ainda gasosa dessa coqueificação de minério, chamado 'gás de coqueria', serve, desde o século XVIII, de combustível para as indústrias, ou canalizada para uso nas residências e para iluminação pública. Nas grandes siderúrgicas, também são recuperados os gases residuais das aciarias; nas indústrias químicas que trabalham com frações do petróleo e dos líquidos de carvão, sobram gases e líquidos residuais que, às vezes, são utilizados para queima na própria indústria petroquímica ou carboquímica.

4) A parte oleosa dos fósseis, presa nas lajes de arenito, misturada com água salgada e gases, é conhecida há mais de mil anos como petróleo, nos poucos locais do mundo onde aflorava ou estava a poucos metros do solo. Somente começou a se usar o petróleo em grande escala há uns cem anos. Desde então, retiraram-se dele as partes mais viscosas para fabricar piche, asfalto e para a queima, como o óleo grosso para fornos e caldeiras dos navios maiores e das centrais termelétricas e casas de força que geram vapor e eletricidade por meio de turbinas. Já as partes mais leves, os 'espíritos e essências' dessa mistura parecida com um chorume dos lixões, utilizam-se para produzir o gás de botijão, 
o querosene, a gasolina e o óleo tipo diesel, que se tornaram os combustíveis básicos da nossa era.

Boa parte do transporte no mundo é feito em veículos queimando gasolina e óleo diesel em motores a explosão. O querosene, além de se usar em lampiões e pequenos motores, queima-se em grande volume nas turbinas a gases quentes que equipam os aviões e helicópteros, além de alguns tipos de embarcação e de trens. Turbinas do mesmo tipo funcionam nas modernas usinas termelétricas queimando um tipo de óleo diesel mais leve, ou o gás metano, associado ao petróleo cru, que sobe de suas jazidas misturado com o gás. Chamado comercialmente de gás natural, pode ser queimado em fornos, caldeiras, também em motores de veículos, e em fogões e fornos.

A possibilidade de substituir os combustíveis fósseis líquidos e gasosos, atingindo-se uma era 'pós-petróleo', é ainda incipiente pelas seguintes razões: a produção do álcool combustível, chamado de etanol, em larga escala (no Brasil e em outras regiões tropicais, à base de cana-de-açúcar; e nas demais regiões, à base de milho e de beterraba) pode complementar ou substituir totalmente apenas a gasolina consumida nos motores a explosão de tamanho pequeno, que equipam os automóveis de passeio; o uso de etanol em motores maiores, dos caminhões, ônibus e máquinas rodoviárias e agrícolas é ainda experimental, bem como a mistura de etanol no óleo diesel convencional, que tem limites mais restritivos do que a mistura do álcool anidro na gasolina; o uso de etanol em turbinas a gases quentes, em substituição ao querosene de aviação, é ainda mais incerto; a adição de óleos vegetais, obtidos da prensagem de soja, girassol, mamona, dendê e outras oleaginosas para uso nos motores tipo diesel está em fase de implantação, com um percentual comercial da ordem de 4 a 5\% nos próximos anos; e apesar de difundida a propaganda em torno de um 'biodiesel', na prática um óleo tipo diesel com 100\% de óleo vegetal está bem longe de qualquer aplicação comercial em larga escala.

Do ponto de vista social e ambiental, tanto a agricultura canavieira como as demais que fornecem matérias-primas para o óleo vegetal apresentam, no caso brasileiro, problemas sérios, como relações de trabalho com muitos indícios de ilegalidade e, mesmo quando legais, com um alto índice de exploração dos trabalhadores, causando-lhes problemas precoces de saúde. Além de terem como base uma notável concentração fundiária, com avanço das grandes fazendas sobre áreas de cobertura vegetal nativa, sobre terras públicas ou territórios indígenas, quilombolas ou de populações tradicionais. Todo o setor de produção e distribuição de etanol está rapidamente se desnacionalizando, em prol de grandes grupos internacionais, que detêm 
cerca de $30 \%$ da produção e que se beneficiam da mesma série de vantagens financeiras e políticas das quais sempre desfrutaram os usineiros brasileiros.

\section{Consequências da Produção, Transporte e Usos dos Combustíveis Fósseis}

Na etapa de extração das fontes naturais, a obtenção do petróleo e do gás que é a ele associado (porque se formaram juntos nas eras geológicas passadas), do xisto betuminoso e do carvão de pedra é uma atividade típica de mineração, ou seja, os materiais devem ser extraídos do subsolo da terra firme, e, no caso do petróleo e gás, também do subsolo do mar. A mineração é uma implantação territorial que demanda o uso quase exclusivo do espaço, o que implica o domínio total de trechos, áreas territoriais e de regiões produtoras inteiras por parte das empresas que operam a extração e o despacho do material extraído para as etapas seguintes.

Em todo o circuito de produção e de consumo, todos esses combustíveis são uma mistura de hidrocarbonetos e necessariamente apresentam uma fase gasosa composta de gás metano, hidrogênio, alguns outros gases, e também alguns compostos líquidos, que evaporam na temperatura ambiente. Por isso, a estocagem e a transferência desses materiais criam focos e trajetos de emanação de hidrocarbonetos, liberando-os na atmosfera. Além disso, os combustíveis de origem mineral, quase sempre vêm contaminados por compostos de enxofre, de nitrogênio e sais e outros compostos de metais pesados, dos quais os mais comuns são os sais de mercúrio, cádmio, cromo, arsênico e cobalto.

A queima em vários tipos de conversores, como fornos, caldeiras, fogões, aquecedores, maçaricos, motores e turbinas, é a etapa final de toda a atividade. Assim, uma consequência inevitável desse processo é o volume considerável de produtos de combustão:

1) Todos os combustíveis orgânicos e fósseis, e também o hidrogênio puro, produzem o vapor d'água e os óxidos de nitrogênio ( $\mathrm{NO}$, $\mathrm{NO}_{2}, \mathrm{~N}_{2} \mathrm{O}$ ), que são precursores da acidez atmosférica e da formação de gás ozônio $\left(\mathrm{O}_{3}\right)$.

2) Quase todos os combustíveis produzem fuligem e cinzas.

3) Aqueles que têm algum teor de enxofre produzem os sulfetos e sulfatos.

4) Na queima de um hidrocarboneto ou uma mistura deles, uma parte desse composto sempre é emitida pelas chaminés e escapamentos sem sofrer queima total, portanto são ainda hidrocarbonetos. 
No caso da queima de combustíveis fósseis, $\mathrm{o} \mathrm{CO}_{2}$ lançado na atmosfera acaba se acumulando, o que está relacionado ao chamado 'efeito estufa'. Combustíveis renováveis, não fósseis, ao mesmo tempo que emitem $\mathrm{CO}_{2}$, também os absorvem no processo de produção pelo mecanismo da fotossíntese. Isso não quer dizer que os biocombustíveis sejam 'limpos', pois a produção de etanol e de outras fontes orgânicas de energia podem causar inúmeros impactos sociais e ambientais.

\section{Mecanismos de Riscos e de Prejuízos durante a Produção de Carvão Mineral}

No Brasil, as regiões produtoras estão no interior do Paraná - próximo à cidade de Tibagi -, no sul de Santa Catarina - municípios no entorno das cidades de Criciúma e Tubarão - e no Rio Grande do Sul - nas margens do baixo rio Jacuí e, na fronteira com o Uruguai, no entorno da cidade de Bagé. Há mais de um século, essas localidades são cenários de esburacamentos sucessivos por cima e por baixo do solo, forjando praticamente um novo relevo. No caso do sul catarinense, a mineração é, até hoje, principalmente subterrânea. Nas regiões carboníferas gaúchas, a maior parte dessa atividade tem sido feita a céu aberto, mas em todos os casos a paisagem ficou igualmente alterada pela formação de extensas pilhas de rejeitos e sofreu processos similares de contaminação química de todo o ambiente: terra, subsolo, ar e água, podendo atingir áreas de dezenas de milhares de hectares.

Inicialmente, extraía-se o carvão mineral por baixo da superfície, furando-se as galerias que continham os veios, à semelhança do recheio de um sanduíche, entre rochas diferentes das do carvão mineral. E, então, retirava-se o minério abatido das galerias após a seleção manual das pedras que interessavam - as carboníferas. Depois, passou-se a detonar as paredes rochosas das galerias e dos salões subterrâneos e a se lavrar mecanicamente o minério. Essa operação visa a obter o material dos veios carboníferos, mas, na prática, o minério abatido é retirado e colocado na superfície, onde então ele é britado e processado, utilizando-se muita água para se conseguir separar o carvão que estava 'ensanduichado' na rocha.

Além das liberações de gás metano, que está impregnado nas camadas fósseis e areníticas e cujos bolsões podem sempre 'flashear' (inflamar e explodir), o minério lavrado contém resíduos de gás radônio, radiativo. No caso do minério do sul catarinense, todas as camadas vêm impregnadas da famosa pirita (ouro de tolo), de cor amarelo-acobreada, composta de sulfetos metálicos, principalmente ferro e manganês, mas com pequenas proporções 
de outros compostos metálicos pesados. Entre eles, os mais frequentes são o cádmio, cromo, arsênico e, mais raramente, chumbo e mercúrio.

Na época pioneira do sul catarinense, parte do carvão já beneficiado era usada para transportar a própria produção, queimado nas caldeiras das locomotivas da estrada de ferro Dona Teresa Cristina. A ferrovia passava pelas minas nos altos rios Tubarão, Urussanga e Mãe Luzia, coletando a produção de carvão e transportando trabalhadores e mercadorias no sentido inverso. Passava pela cidade de Tubarão - onde se construiu, no começo de século XX, a primeira usina termelétrica no distrito de Capivari - e depois seguia até o porto de Laguna - onde se despachava o combustível para outras cidades, para ser usado nos fornos de cimento e de fundições metálicas, para os gasômetros e para outras usinas térmicas.

Em meados do século XX, com a Segunda Guerra Mundial, o país entrou na era da siderurgia de grande escala. O governo federal firmou uma sociedade com United States Steel para implantar a Companhia Siderúrgica Nacional (CSN), em Volta Redonda. De acordo com a lei vigente na época, nos altos-fornos da CSN seria obrigatório manter uma cota minoritária de uso de carvão nacional, e a maioria seria de carvão importado. A CSN deslocou o eixo da mineração de carvão para perto de Criciúma, com a mina Nova Próspera, no bairro Sangão, e mais ao norte fundou a cidade de Siderópolis. Nos terrenos em torno dessa cidade operária, a mitológica dragline Marion, uma escavadeira-guindaste de grande porte, atendeu a toda a demanda durante cerca de quarenta anos (Sevá Filho, 2001). Nos anos 1950 e 1960, outras minas subterrâneas foram abertas em Siderópolis e no seu distrito de Treviso, em Forquilhinha, além das lavras que já funcionavam em locais mais distantes, nas cidades de Urussanga e Lauro Muller. Crescia o fornecimento para a siderurgia e outras indústrias, e começou a construção da nova termelétrica em Tubarão, com 66 megawatts (MW) e depois, com 186 MW.

Nas minas subterrâneas mecanizadas, o minério passava por um primeiro beneficiamento na superfície, com a chamada 'pré-lavagem', para a produção de carvão-vapor (para caldeiras) e de carvão metalúrgico. Este era chamado de 'coqueificável', pois sua estrutura permitia a fabricação do coque, adequado às cargas dos altos-fornos. $\mathrm{O}$ beneficiamento provocava grandes sobras de rejeitos, a maior parte piritoso, com teores importantes de enxofre e metais, começando-se, assim, a formar os pátios e as pirâmides de sobras tóxicas.

Nas primeiras décadas da era siderúrgica, o minério bruto da CSN era embarcado para o lavador de Capivari, em Tubarão, e o carvão dito 
beneficiado era exportado por Laguna. Posteriormente, criou-se em Imbituba um terminal especializado em carvão, com maior calado para os navios, e se construiu ao lado uma unidade química, a Indústria Carboquímica Catarinense (ICC), para recuperar enxofre e ácido sulfúrico do rejeito piritoso e para suprir a indústria de fertilizantes sintéticos com esses produtos. Na mina Nova Próspera, em Criciúma, montou-se, então, uma grande estrutura de separação de pirita, que fornecia a matéria-prima para a ICC, de Imbituba, formando-se, assim, uma área degradada no distrito do Sangão, próximo de onde hoje estão a Universidade do Extremo Sul Catarinense (Unesc) e o aeroporto regional. Essa área é uma das maiores extensões contínuas de pilhas de rejeitos e de bacias e pátios abandonados e contaminados de toda a região, possivelmente de todo o país.

Como em todas as pilhas de rejeitos ao ar livre, as camadas mais rasas de pirita entram em combustão espontânea, conforme a luz, a umidade, os ventos, e emana do chão a conhecida fumacinha de gases sulfurosos e sulfetos. Em Siderópolis, e nos lugares onde esteve em sua excursão devoradora, o rastro da passagem da escavadeira Marion é bem típico: as pilhas cônicas de descartes rochosos da escavação a céu aberto (arenito, siltito e outros, todos com pirita incrustada).

Em todos os municípios onde funcionaram minas com mecanização, com retirada de todo o minério bruto das galerias, operavam as instalações de superfície chamadas de 'lavadores', e, como resultado, restavam os pátios pavimentados, as pirâmides e taludes de rejeitos piritosos da lavagem. Entre as pilhas e as pirâmides, tentam passar os 'ex-riozinhos', espremidos ou bloqueados de vez, e acabam engolidos por grandes cavas com muitos metros de fundura, formando novos açudes e alagados bastante ácidos.

Basta circular pela região durante o dia e ver lagos de cores e consistências nunca vistas alhures: verde-claro leitoso, amarelo-ouro, cor de laranja, azul-turquesa transparente, vermelho-cobre, cinza-chumbo espesso. São marcas registradas da paisagem sul catarinense, mas também podem ser encontradas nas demais localidades carboníferas esses reservatórios coloridos envenenados, continuamente abastecidos pela passagem da água de chuva nas pilhas.

Não são somente esses os prejuízos, uma vez que, como ocorre em toda mineração, tanto a escavação aberta como a lavra subterrânea alteram os lençóis d'água subterrâneos, ou interrompendo sua trajetória de recarga do rio ou formando novos açudes e enchendo cavas. Nas galerias e salões do subsolo também mina muita água, que deve ser retirada e posta na superfície. 
Com isso, secam as fontes de água nos morros acima e ao lado das galerias, rebaixando-se em muitos metros o nível do lençol subterrâneo. Há, portanto, o risco de falta de água. Essa foi precisamente a causa do enfrentamento social que eclodiu em Criciúma em 1996, quando um empresário pretendeu prolongar uma galeria da mina Nova Próspera, 'herdada' da CSN após sua privatização, que se localizava exatamente por baixo dos morros Estevão e Albino, ocupados por pequenos e médios agricultores.

Logo após a Câmara Municipal reconhecer o local como Área de Proteção Ambiental (APA), o Fórum de Justiça, onde houve a sessão pública dos vereadores, foi depredado, como forma de protesto, pelos sindicalistas e trabalhadores das minas, os quais foram, por sua vez, reprimidos por tropas da Polícia Militar (PM) estadual. O que estava em jogo era, de um lado, a água dos morros e a sua economia agrícola, e, de outro, mais uma frente de lavra de carvão (Sevá Filho, 2001).

Quinze anos depois, a mesma batalha continua em outros municípios, e, no boletim informativo eletrônico de uma entidade ambientalista, conclamam-se os habitantes de Maracajá a resistir a um projeto de mina no município, e se recapitula a luta regional:

O município de Araranguá se protegeu criando legislação específica contra a exploração de carvão mineral em seu território, como também inseriu na Lei Orgânica do Município, baseada nos mesmos moldes de Orleans e Cocal do Sul que resistem pela não instalação de minas de carvão. A comunidade agrícola do Morro Estevão e Albino resistiu heroicamente e não permitiu a mineração, enquanto a comunidade rural Santa Cruz de Içara, apesar de toda a resistência, não conseguiu impedir a Rio Deserto de iniciar as escavações e ameaçar o comprometimento dos sistemas superficiais e subterrâneos de recursos hídricos, que proporcionam produtividade à terra, terra que dá subsistência aos agricultores. (Sócios da Natureza, 2011)

A mineração subterrânea continua a provocar sequelas graves até mesmo quando é abandonada: com a desativação, às vezes, retiram-se também as pilastras rochosas que ainda contêm um pouco de carvão, e se deixa de bombear a água dentro das galerias. Os dois fatos podem levar à inundação das galerias e provocar desmoronamentos e afundamentos do teto, o que significa, em alguns casos, maior risco de afundamento do solo, maior risco de tremores acima das galerias - é o que, notoriamente, ocorre em boa parte da atual área urbana de Criciúma, toda furada por baixo e sujeita a detonações próximas.

Os rios que descem da Serra do Mar já eram torrenciais, pois são curtos e drenam as águas de bacias extensas, sujeitas a chuvas concentradas em 
certas épocas do ano. Após a era da mineração, a fúria dos rios aumenta, com o entupimento de lodo, borra e até de rejeitos rochosos. Além disso, agora sua enxurrada é tóxica, e cada rio vai disseminando por novos trechos sua carga de acidez e seu teor relevante de metais pesados, além de um tanto de óleo, finos de minério e de carvão e de outras cargas orgânicas.

Quando os índices do potencial hidrogeniônico $(\mathrm{pH})$ - que mede o grau de acidez ou alcalinidade de um meio - de alguma solução estão abaixo de 4 ou 3, ou seja, cem, mil vezes mais baixos do que o $\mathrm{pH}$ neutro (em torno de 7), esse meio, que está muito ácido, favorece também a liberação e solubilização de metais pesados. Se isso acontece em um ambiente onde vivem e se reproduzem algumas formas de vida aquática elementar - plânctons, algas, bactérias -, pode ocorrer o processo de biometilação desses metais nos organismos, que são as bases da cadeia alimentar, configurando um vasto processo de contaminação bioquímica.

Dessa forma, a correnteza espalha os vários efeitos danosos, atingindo os ciclos da vida aquática. Entre os prejuízos estão a redução de oxigênio dissolvido na água, a acidez e os altos teores de sulfetos e de compostos de metais pesados na água e nos sedimentos. No sul catarinense, cada um dos três maiores rios - Tubarão, Urussanga e Mãe Luzia - juntam vários afluentes que passaram exatamente pelas terras mineradas. Esses rios têm suas margens quase sem mata e encostas, com várzeas destruídas - uma faixa de cor enferrujada acima da linha d'água -, e estão próximos a terrenos estéreis, cinza-escuros, negros, alguns disfarçados por bosques ralos de eucaliptos resistentes e por 'jardins' de samambaias espinhentas, adaptadas à acidez.

Os ambientes de todas as atividades que envolvem a produção de carvão mineral, desde o interior das galerias, onde a jazida é desmontada com explosivos e máquinas, durante o transporte em esteiras rolantes, caminhões e trens, até o uso final nos fornos e caldeiras, são empoeirados do mal-afamado pó preto, pegajoso, engordurado. As pessoas que ali trabalham e os vizinhos próximos ficam sujeitos a vários tipos de injúrias, doenças profissionais e acidentes. Esse é, infelizmente, o destino de todas as regiões carboníferas, e é ainda pior no Brasil, onde essa degradação ambiental criminosa é chamada, com hipocrisia, de 'poluição sem dono'.

\section{Usos do carvão mineral: eletricidade e produção de aço}

Inicialmente, como já dito, o carvão era utilizado nas locomotivas ferroviárias, nos gasômetros de várias cidades para fornecimento de gás canalizado de uso urbano geral, em especial para a iluminação pública e 
para os fornos metalúrgicos. Atualmente, porém, é utilizado principalmente nas usinas termelétricas em funcionamento no Paraná, em Santa Catarina e no Rio Grande do Sul, nos fornos rotativos de algumas indústrias cimenteiras e nas usinas siderúrgicas integradas.

Contudo, para a fabricação do aço nos altos-fornos convencionais, é preciso que o carvão seja transformado em coque. Isso é feito nas unidades especiais das siderúrgicas, chamadas 'coquerias', onde se cozinha o carvão com pouco oxigênio, fazendo-o atingir uma concentração do elemento carbono bem maior, além de se retirar a maioria dos compostos voláteis, que, por sua vez, dão origem a uma verdadeira indústria carboquímica acoplada a essas siderúrgicas. Essa atividade é a origem de um dos problemas de saúde mais graves: a emanação e o lançamento na atmosfera de hidrocarbonetos aromáticos (benzeno, tolueno, xileno), reconhecidamente fatores de risco para a alteração sanguínea chamada de leucopenia, que é a diminuição da taxa sanguínea de leucócitos abaixo do limite inferior da normalidade e que pode ocorrer em várias afecções, até mesmo na leucemia.

Nas próprias regiões carboníferas brasileiras, queima-se o minério nas coquerias; várias delas são bem rudimentares, e as descargas das chaminés dessa coqueificação, bastante nocivas, contêm voláteis aromáticos, além de gás sulfuroso, fumaças e fuligens. Posteriormente, vende-se o coque, bem como as moinhas e finos recuperados do carvão, para fornos de outras indústrias, como olarias e cerâmicas que ainda queimam carvão, e poucas caldeiras industriais. Mas o carvão brasileiro está atualmente fora do suprimento das grandes siderúrgicas brasileiras, que utilizam totalmente o carvão importado em suas coquerias. A demanda da CSN, bem como todo o esquema instalado na carboquímica ICC durante os anos 1970 e 1980, findaram no período do governo de Fernando Collor de Mello, que zerou as alíquotas de importação e suspendeu a cota obrigatória de carvão brasileiro em Volta Redonda.

O ciclo do carvão teria se encerrado se não fossem as novas demandas para a termoeletricidade, que foram contratadas depois das ampliações (unidades 5 e 6) da usina em Tubarão, de 186 para quase $440 \mathrm{MW}$ instalados, e depois, com a grande unidade geradora 7, com $350 \mathrm{MW}$ a mais, que começou a operar no final da década de 1990. Essa megacentral termelétrica, uma das maiores do país, era da empresa federal Eletrosul. Atualmente, privatizada e rebatizada Gerasul, pertence à europeia Tractebel e forma o Complexo Termoelétrico Jorge Lacerda. Suas sete caldeiras, se estiverem à plena carga, queimam algumas centenas de toneladas de carvão a cada hora e algumas centenas de 
milhares de toneladas mensais. Mas é um combustível de baixa qualidade, comparado aos padrões internacionais, com teores de $40 \%$ de cinzas e de 1,8 a 2,5\% de enxofre e poder calorífico em geral baixo, de 3.500 a $4.500 \mathrm{~kg}$. Por isso, esse complexo termoelétrico é uma instalação muito fumacenta, mesmo se considerando que a maior parte do material particulado bem fino (fly ash) é retido nos precipitadores do tipo eletrostático - na prática, é um dos raros equipamentos de redução de poluição desse tipo existentes no país.

A utilização de água, necessária para o resfriamento das máquinas e para a condensação do vapor, após passar pelas turbinas a vapor, é da ordem de 15.000 litros/segundo, equivalente a uma cidade de quase quatro milhões de habitantes. A maior parte dela retorna quente ao rio Tubarão, mas a unidade 7 , a mais nova e de maior potência, usa uma torre de resfriamento semiaberta, onde há uma grande perda evaporativa para a atmosfera (Sevá Filho, 2001).

Não bastasse essa grande termelétrica no sul catarinense, há mais de quinze anos pressiona-se o lobby carbonífero a instalar uma central com potência prevista de mais de $400 \mathrm{MW}$, a Usina Termelétrica Sul Catarinense (Usitesc). A localidade que seria sacrificada pelas sequelas de mais essa usina é Treviso, vizinha à Siderópolis, na mesma rede fluvial do rio Mãe Luzia, no sopé da Serra Geral, a poucos quilômetros dos limites de dois parques nacionais (PN Aparados da Serra e PN São Joaquim).

Um veredicto ambiental similar a esse valeria para todas as demais usinas termelétricas queimando carvão no país, as quais atualmente consomem cerca de cinco milhões de toneladas de carvão/ano. E, provavelmente, a situação se repetirá caso se instalem as três novas centrais térmicas a carvão, de grande capacidade (potência de centenas de megawatts), previstas para funcionar no Ceará (próximo ao polo industrial de Pecém, para onde também se preveem uma nova refinaria de petróleo e uma usina siderúrgica); na ilha de São Luiz, Maranhão; e próximo à Barcarena, na margem direita do baixo rio Tocantins, Pará. Todos esses casos ocasionam conflitos ambientais presentes no Mapa de Conflitos da Fundação Oswaldo Cruz e da Federação de Órgãos para Assistência Social e Educacional (Fiocruz/Fase).

Esses projetos de novas usinas pouco se justificam por qualquer carência regional de eletricidade. Explicam-se exclusivamente pelas supostas vantagens do comércio internacional de carvão, com oferta atualmente abundante e a baixos preços, sobretudo o proveniente da China. Não por coincidência, são projetos anunciados pela antiga Companhia Vale do Rio Doce, a atual Vale, e pelo grupo empresarial Eike Batista. Segundo diversas denúncias, tais projetos são conhecidos pelo uso simultâneo de truculência e 
de cooptação das populações residentes nos locais escolhidos para hospedar esses projetos e das entidades de defesa local e ambientalistas que porventura discordem da instalação de tais usinas.

O volume de importação de carvão mineral pelo Brasil atualmente ultrapassa os 20 milhões de toneladas/ano e se destina principalmente à produção de coque nas seis grandes usinas siderúrgicas integradas: a CSN, já mencionada; a Cosipa, em Cubatão (SP); a Açominas, em Ouro Branco (MG), próxima de Congonhas do Campo; a Usiminas, no Vale do Aço, na cidade de Ipatinga (MG); a Companhia Siderúrgica de Tubarão (CST), em Vitória (ES); e a Companhia Siderúrgica do Atlântico, inaugurada em 2010 entre a cidade de Sepetiba e o distrito de Santa Cruz (RJ).

Poucas e poderosas empresas industriais dominam essa constelação de grandes usinas: o grupo Vicunha (Steinbruch); a Vale, atualmente comandada pelo Banco Bradesco, o grupo japonês Mitsui e fundos de pensão brasileiros; a também japonesa Nippon Steel; o grupo europeu Arcelor-Mittal; o grupo Gerdau, multinacional de origem gaúcha; e a alemã ThyssenKrupp.

O carvão mineral e o coque importados vão, aos poucos, entrando no suprimento dos altos-fornos dos pequenos e médios produtores de ferro-gusa, os guseiros, deslocando-se, assim, o uso de carvão vegetal aqui produzido. Ambientalmente, consideramos essa tendência negativa, na medida em que o combustível fóssil e a mineração são claramente desvantajosos. Com essa argumentação, não se pretende eximir a produção local de carvão vegetal de uma série de problemas fundiários, sociais, trabalhistas e ambientais bastante conhecidos e, até aqui, sem perspectiva de solução honrosa. Contudo, como combustível, o carvão vegetal é mais eficiente e menos poluente do que o mineral, além de não ser um recurso finito.

\section{A Complexa Infraestrutura do Petróleo, as Pessoas e Regiões Afetadas e sob Risco}

A indústria petrolífera tem como base uma infraestrutura física que vai se ramificando sem parar desde que começou a ser implantada, há um século e meio, fazendo prospecções pelo mundo afora, plantando sondas e furando poços, lançando e engrossando dutos e terminais como se fossem os galhos de uma floresta intrincada. Nos cruzamentos mais estratégicos dessa rede, continuamente foram construídas as refinarias de petróleo e as unidades de processamento de gás natural (UPGN).

As rotas que chegam a essas indústrias e delas saem vão formando malhas e redes cada vez mais amplas e entrecruzadas, varrendo os mapas, 
esquadrinhando e esquartejando os espaços geográficos. Redefinindo-se, assim, a geografia do mundo conforme as suas próprias necessidades e conveniências. Essa situação se comprova na descrição a seguir.

A prospecção e a produção de petróleo e gás ocorrem no mar, na terra, e também na interface mar-terra, ou seja, nos litorais, nas ilhas e arquipélagos, nos estuários e bocas dos rios, nos manguezais. Os trajetos de coleta, transferência e estocagem de matéria-prima, e as rotas de distribuição de produtos passam por quase todos os lugares: mar, continente, incluindo rios e desertos, e até pelo espaço aéreo, já que há lugares onde os combustíveis só podem chegar pelo ar. Os dutos, os tanques, os postos de serviço, as refinarias e as outras unidades de processamento industrial ocupam pontos e faixas das áreas urbanas e rurais, as bordas dos desertos e da tundra gelada, cruzam florestas, rios, baías, lagos, pantanais e manguezais, furam planícies, morros, serras, vão pelo fundo dos mares.

A etapa 'final' dessa indústria acontece principalmente na queima dos derivados e do gás nos motores, fornos, caldeiras, turbinas, fogões. Porém, muito antes, já provocou enormes consequências, já que aqueles focos e faixas de exploração e distribuição ficam cravados no chão e na água, onde, segundo as estatísticas, continuarão ocorrendo incidentes, problemas, acidentes e, às vezes, tragédias para os trabalhadores e para os vizinhos. E esses problemas afetarão certamente outras formas de vida, hábitats, ecossistemas, recursos hídricos e a atmosfera do planeta.

A indústria petroleira, para poder ser construída, materializada, e também para ser colocada em funcionamento, queima uma boa proporção dos derivados e do gás que ela mesma produz. A visão das tochas com chamas altíssimas nas refinarias e nas plataformas de produção não é uma fotografia de um evento excepcional, mas, sim, um emblema do cotidiano dessas instalações, uma vez que as tochas são equipamentos de segurança e devem estar sempre acesas para queimar o excesso de hidrocarbonetos que resultam do desbalanceamento constante dessa atividade industrial.

Além disso, para se levar homens e materiais para o trabalho diário no meio da selva ou em alto-mar, gastam-se muito óleo diesel nos rebocadores e querosene nos helicópteros; em navios-tanque, nos trajetos entre os continentes e em barcaças-cisterna, no trajeto entre os portos fluviais, gasta-se uma quantidade de combustível equivalente a um alto percentual da matériaprima que transportam; com os caminhões-tanque que levam óleo diesel a milhares de quilômetros de distância também acontece de forma similar. 
Para se construir um panorama fiel dessa trama industrial, geográfica, ambiental e humana espalhada por todo o mundo e, particularmente, por todo o imenso Brasil, um dos passos mais difíceis é a identificação dos sujeitos participantes, dos agentes mais próximos e mais distantes dessa cadeia produtiva e de consumo, e de seus múltiplos efeitos no território e na saúde. Nem mesmo os principais agentes dessa indústria, os seus trabalhadores, os gerentes, os dirigentes das empresas têm essa noção completa. Na realidade, alguns efeitos são percebidos, por vezes, somente por outras pessoas: os vizinhos das instalações, aqueles que moram e trabalham perto das refinarias, dos terminais de embarque e desembarque de petróleo e de gás natural e dos seus produtos derivados. E há, ainda, consequências que somente aparecem depois de algum tempo, por exemplo, as doenças profissionais adquiridas por vários grupos de trabalhadores que respiram ou manuseiam certos tipos de substâncias tóxicas.

Obviamente, os trabalhadores são os primeiros a serem atingidos pelo petróleo, mas eles podem se considerar - ou não - vítimas ou prejudicados pela indústria. Independente dessa avaliação feita pelas próprias vítimas, objetivamente uma boa parcela deles sofre acidentes, fica doente, desequilibrada, ou fica mutilada ou incapaz; e ainda uma parte continua falecendo no trabalho, no trajeto, por causa de sua atividade profissional. Além dos trabalhadores atuais, devemos incluir nesse grupo de atingidos aqueles que trabalharam anteriormente em alguma instalação petrolífera ou durante as fases de construção dessas instalações. Incluem-se também aquelas equipes itinerantes especializadas nos trabalhos das etapas de manutenção, durante as quais os equipamentos e setores das unidades industriais são desmontados, trocados, reconstruídos, e suas partes e peças são desengraxadas, limpas, jateadas, soldadas, pintadas etc., que podem ter carregado em seu corpo o próprio 'passivo', ou seja, as cicatrizes, os traumas e as patologias adquiridos durante a realização do trabalho.

Entre os primeiros a serem atingidos devemos incluir ainda aqueles que moravam no local durante da instalação da indústria. Talvez muitos deles precisaram se mudar para perto ou muito longe.

Os vizinhos atuais da indústria estão também nesse primeiro grupo atingido. De modo similar aos trabalhadores, eles podem se considerar - ou não - prejudicados ou vítimas, mas, objetivamente, a poluição decorrente da atividade petrolífera cresce gradativamente no entorno das instalações, dos estoques e dos trajetos. Não há possibilidade, em termos lógicos, de a poluição no entorno de uma refinaria ou de um terminal petrolífero ser 
decrescente ao longo do tempo, de melhorar, na medida em que as sequelas serão sempre cumulativas.

A questão do risco, que é probabilístico, correlaciona a frequência à gravidade dos acidentes: mesmo que em certo local - seja plataforma, campo de extração, dutovia, terminal marítimo, fluvial ou terrestre, refinaria ou UPGN - ainda não tenha ocorrido um acidente grave, explosão, incêndio, nuvem tóxica, derrame tóxico etc., já aconteceram problemas desse tipo em boa parte de locais que abrigam indústrias, no Brasil e em outros países. Portanto, em cada local, o risco permanece.

A busca de uma investigação rigorosa nos obriga ainda a destacar, em primeiro plano, nessa categoria de atingidos, vítimas reais, passadas ou futuras, aqueles que vivem em uma condição dupla, sobreposta de ameaças por parte da indústria, uma vez que foram ou são simultaneamente trabalhadores e moradores vizinhos ou estão próximos do risco e dos prejuízos típicos da atividade petrolífera.

O risco é intrínseco a essa indústria, principalmente pelo fato de se manusear e se controlar fluxos de hidrocarbonetos, que são inflamáveis e, em boa parte, voláteis; além disso, se utilizam insumos químicos tóxicos, explosivos, materiais radiativos. Como os equipamentos e reservatórios trabalham sob pressões altas e sob condições mecânicas não usuais - até mesmo corrosão -, rompimentos, vazamentos e derramamentos são frequentes, e, em muitos casos, são eventos bem pouco controláveis depois de iniciados.

\section{Problemas e Riscos da Atividade Petrolífera em Alto-Mar}

Na etapa inicial de produção de petróleo, a prospecção, buscam-se evidências da presença de petróleo e gás no subsolo, em geral a mais de dois mil metros de profundidade abaixo do piso do mar. Um dos métodos mais utilizados, além dos sobrevoos de aeronaves equipadas com radares e emissores magnéticos, é a chamada 'prospecção sísmica'. Essa técnica consiste em provocar detonações, uma grande série de pequenas explosões no piso do mar, seguindo linhas retas e malhas de linhas paralelas. Assim, podemse captar por meio de sensores as diferentes reflexões dessas detonações na estrutura interna do subsolo, fazendo com que se interpretem ou se modelem as características das rochas onde estão o óleo e o gás entranhados. Os navios de prospecção têm canhões de ar comprimido na popa, dirigidos para o fundo do mar, e lançam cabos com sensores, cujos trajetos varrem numerosas vezes 
as áreas-alvo, que são os polígonos ou 'blocos' licitados pela Agência Nacional do Petróleo (ANP) e arrematados pelas empresas petrolíferas.

Caso se decida perfurar um poço em uma área considerada promissora, entram em campo os navios-sonda, que furam o solo utilizando como lubrificante uma lama de argila com aditivos químicos e jogam ao mar quase todo o cascalho retirado da perfuração. Se forem considerados aptos, os poços são completados com tubos metálicos e cimento, para que se tornem estruturas rígidas, verdadeiras colunas sólidas dentro do solo.

Durante essas etapas, sobem bolhas de gás (kicks) ou grandes erupções de gás (blow outs) que golpeiam as linhas de tubos e, às vezes, as próprias embarcações, podendo romper os dutos no meio do caminho, ou chegar até o convés, provocando vazamentos e incêndios. As rochas, no entorno do final de cada poço, na parte mais funda, são objeto de pequenas demolições, feitas com tiros de canhão disparados para abrir espaços ocos nas rochas e, assim, forçar o fluxo do óleo em direção ao tubo ascendente.

Para coletar e direcionar os fluxos de matérias-primas, equipam-se os poços com válvulas no piso do mar ('árvores de natal'), e várias delas estão interligadas por tubos rígidos e flexíveis, que convergem para outros conjuntos ainda maiores de válvulas que também são colocadas no piso do mar (manifolds). Geralmente, uma mesma plataforma está conectada a um ou mais desses manifolds, de tal modo que o pessoal e os equipamentos de cada plataforma operam simultaneamente alguns ou vários poços, cujas cabeças ficam interligadas como se fossem os fios de uma teia de aranha no piso do mar.

De algumas dessas plataformas, das que ficam na faixa mais próxima da costa, saem dutos submarinos de óleo e de gás, para cuja construção os tubos e conexões foram lançados e posicionados por meio de navios especiais (pipe layers). Esses gasodutos e oleodutos-tronco vão pelo piso do mar até o continente, de onde são conectados por meio de dutos terrestres às refinarias e às UPGN. Por exemplo, no Norte Fluminense, os dutos principais saem das plataformas de Enchova, Namorado, e Garoupa, entram em terra firme próximo a Macaé, e prosseguem até Duque de Caxias, na baía da Guanabara (Sevá Filho, 2010).

Plataformas e navios de produção, muitas vezes, funcionam sem conexão com o continente. Quando ficam muito distantes da costa, as plataformas não são conectadas por dutos submarinos a essa rede que leva ao continente. Adota-se a alternativa de se colocar ao lado delas uma plataforma auxiliar ou um grande navio-tanque, que dispõem de uma grande capacidade de 
armazenagem de petróleo (centenas de milhões de litros) e que permitem a atracação de embarcações de grande porte porque são construídos e ancorados para isso. Esses recursos - plataforma auxiliar ou navio-tanque são chamados de 'monoboias', e sua função principal é o carregamento, em alto-mar, dos navios-tanque ou petroleiros que transportam o óleo para os terminais litorâneos, os quais estão localizados em Suape (PE); em Madre de Deus, na baía de Todos os Santos (BA); em Angra dos Reis (RJ); em São Sebastião (SP); em frente a São Francisco do Sul (SC); e em Tramandaí (RS), onde operam também tipos similares de monoboias.

Alguns dos problemas ambientais estão relacionados justamente a essa etapa, porque, nas manobras de carregamento dos navios em altomar, pode haver derramamentos, além de sempre ocorrer a emanação de hidrocarbonetos voláteis, que são tóxicos para os humanos e podem explodir ou incendiar a área.

Os efeitos em terra da exploração de petróleo e gás no mar são muitos e variados, usualmente desconhecidos fora das regiões petrolíferas. Além das várias situações de risco mencionadas no alto-mar, as atividades do tipo offshore provocam também diversos e duradouros efeitos na costa litorânea mais próxima, onde ficam as cidades e instalações que servem de base para a atividade no mar, e mesmo em litorais mais distantes, onde ficam os portos que recebem os navios-tanque.

Nos terminais litorâneos, aonde chega o óleo cru vindo das plataformas, existem, além dos dispositivos de atracação e de bombeamento, grandes parques de tanques para armazenamento, onde se separa do petróleo a água de formação, o que significa descartá-la em algum córrego - como acontece no terminal Tebar, no litoral norte de São Paulo: o córrego desemboca na praia do Porto, perto do centro da cidade de São Sebastião, que é também um polo turístico. A alternativa é se descartar essa água de formação, oleosa e cheia de compostos químicos tóxicos, diretamente no mar, com ou sem o devido tratamento.

Esse é um dos principais problemas ambientais da indústria, difícil de se resolver: a água de formação sobe em emulsão junto com o petróleo, em volumes que podem chegar a quase $50 \%$ do volume total de petróleo. Como esse custo de transportar água não é interessante, e como, ao entrar na refinaria, o petróleo não pode conter água em teores superiores a $1 \%$, o que ocorrerá é o despejo de toda essa água de formação no mar, nos córregos ou lagos que recebem águas pluviais ou esgotos dos terminais, ou nos cursos d'água que cruzam a região produtora de petróleo em terra. 
A menos que haja poços especialmente construídos para a reinjeção dessa água de formação na própria rocha sedimentar de onde o petróleo foi retirado: única solução correta, porém muito cara e raramente adotada.

Em decorrência do fato de que os navios-tanque, quando vazios, devem ser enchidos com água de lastro para aumentar o seu peso e favorecer uma flutuação equilibrada, ocorrem dois problemas ambientais graves: ao esvaziarem seus tanques nos terminais, é necessário captar água doce por ali mesmo para formar o lastro desses grandes navios-tanque; e, quando atracam nas monoboias, para encher os tanques com petróleo, ou nos terminais litorâneos, para encher com derivados de petróleo, esses navios despejam no local sua água de lastro contaminada.

As plataformas e os navios de produção se abastecem regularmente por meio de navios rebocadores, com materiais vindos da terra, inclusive água potável proveniente de algum rio próximo das bases terrestres do offshore. As plataformas despejam no mar os restos de comida e dejetos humanos de sua tripulação, o que serve de atrativo para os cardumes. Entretanto, as sucatas e os resíduos sólidos não podem ser lançados no mar, devendo ser despachados para o continente por meio desses navios-rebocadores.

Nas plataformas e nos navios de produção, o óleo cru é separado do cascalho, que sobe junto do óleo pelos poços, e também de uma grande parte da água que coexiste com o petróleo dentro da rocha desde os tempos geológicos da sua formação e é uma espécie de salmoura, repleta de compostos químicos. Ambos, cascalho e água, são descartados no mar, bem como os vazamentos eventuais das tubulações ou decorrentes de acidentes.

A indústria petrolífera redesenha os territórios conforme a sua conveniência e poderio nos mares onde ela navega e ancora seus navios-sonda e seus navios e plataformas de perfuração. Onde ela estaciona as unidades flutuantes de produção, lança suas redes submarinas de dutos, reina absolutamente, restringe e expulsa os demais usuários. Contando sempre com o apoio das Capitanias dos Portos, a indústria petrolífera define e faz valer áreas de restrição à navegação a quaisquer outras embarcações que não as suas. Também pratica seguidas apropriações privadas do mar, delimitando imensas áreas de exclusão de pesca, algumas delas com quilômetros de largura em torno das plataformas e das linhas de gasodutos e oleodutos, utilizando argumentos, nem sempre consistentes, que dizem respeito ao 'risco' que há para pescadores e empresas de pesca e para a operação de toda a logística petrolífera se permanecerem na área. 
O problema também atinge o cercamento do litoral e do próprio mar, próximo e distante da costa. Os estaleiros e canteiros navais fazem a montagem e manutenção de plataformas e exigem exclusividade nas rotas de acesso às suas docas para fundear as embarcações e fazer as dragagens sistemáticas do fundo do mar, de modo a mantê-lo adequado para os grandes calados das embarcações fabricadas atualmente. Essa situação ocorre, por exemplo, nas imediações dos estaleiros em Angra dos Reis e em Niterói, e mais recentemente na baía de Todos os Santos, em São Roque do Paraguaçu, e já começou a ocorrer com o estaleiro em fase de construção no Porto Açu, mais uma megaobra da empresa OSX do grupo Eike Batista.

O cercamento se completa com a multiplicação das áreas reservadas exclusivamente para a prospecção e para a exploração do petróleo em alto-mar: os entornos e as faixas de 'proteção' das rotas dos navios de mergulho e de colocação de dutos, cabos elétricos e fibras óticas, das plataformas de perfuração, e das de produção de óleo e gás, e das plataformas de injeção, das monoboias, dos depósitos flutuantes de combustíveis e das unidades de manutenção e segurança (UMSs), conhecidas como hotéis flutuantes ou 'flotéis'.

No caso de campos produtores mais antigos, há também as restrições à navegação e à pesca em razão da perfuração de novos poços e da instalação de novos equipamentos de processamento e bombeamento submarino para se continuar explorando jazidas já sacrificadas, em declínio, a exemplo do que se faz atualmente na bacia de Campos, no entorno dos poços interligados à plataforma de Cherne 2, onde está estacionada a UMS Arraial do Cabo. Outra UMS, com capacidade para hospedar até quatrocentas pessoas, opera no campo de Enchova, e outras duas começaram a ser construídas em 2011 para apoiar a intensificação da produção na bacia de Campos.

Essa prática é um fenômeno impressionante e bastante desconhecido da sociedade e pode ser entendido como um loteamento do mar. Os casos de loteamento do litoral norte fluminense, de Macaé até Arraial do Cabo, estão compilados em Sevá Filho (2010). Outras informações podem ser encontradas, além dos sites oficiais das empresas, em revistas de negócios. Por exemplo, na revista Brasil Energia inúmeras páginas têm sido dedicadas nos últimos anos a informar e elogiar as 'novas maravilhas' previstas para dar prosseguimento ao grande projeto da indústria petrolífera no Brasil, a exploração da camada chamada 'pré-sal', a centenas de quilômetros da costa dos estados do Espírito Santo, Rio de Janeiro, São Paulo, Paraná e Santa Catarina, e a profundidade de 5 a 6 mil metros abaixo do piso do oceano. 
Essas indústrias petrolíferas são verdadeiras fábricas submarinas com equipamentos de grande porte e complexidade mecânica e elétrica concebidos para operar sobre o piso do mar, manobrando os fluxos dos poços e fazendo a separação prévia das três fases da mistura que sobe das rochas areníticas (óleo, gás e água de formação).

No caso do pré-sal da bacia de Santos, está incluída a instalação de um anel de fibra ótica submarino, com mais de $2 \mathrm{mil} \mathrm{km}$ de extensão que interliga 12 novas plataformas. Prevê-se também a construção de uma super UMS, anunciada como uma futura ilha artificial. A unidade vai servir de apoio para a produção nessa região oceânica, uma tentativa de amenizar a difícil logística atualmente empregada nas plataformas do pré-sal que ficam a $300 \mathrm{~km}$ da costa ou mais.

Atualmente o trânsito de pessoal e material leve é feito por helicópteros de grande porte (18 passageiros) que operam no aeroporto de Jacarepaguá (RJ), levam mais de uma hora de voo até as plataformas e geram alto custo. Após a ampliação do aeroporto da cidade de Cabo Frio e da construção de uma nova pista e de uma estação na base aérea de Santos, a ilha artificial deverá permitir o transporte de pessoal em duas etapas: as grandes lanchas de duzentos passageiros, cujo uso estava abolido desde 2005, iriam até o flotel que, nesse caso, é uma enorme embarcação de estrutura semissubmersível, ancorada, com hospedagem para quatrocentas pessoas. Em seguida, os helicópteros comuns decolariam de quatro heliportos até as plataformas, prevendo-se, assim, fluxos de meio milhão de passageiros/ano. Ao mesmo tempo, haveria um aumento da carga transportada de terra firme para as plataformas em alto-mar, dos atuais 350 mil toneladas/ano para 1 a 2 milhões/ ano, o que exigiria a ampliação da frota de barcos de apoio (rebocadores e outros), de 200 para 450.

Assim é o capitalismo petrolífero: não se enxergam limites nem dificuldades intransponíveis. As corporações empresariais parecem cada vez mais poderosas e duradouras. Aliás, são praticamente as mesmas que constroem e operam em outros setores da indústria e infraestrutura: Andrade Gutierres, Odebrecht, Queiroz Galvão, Engevix, Schahlim e outras. Essas empresas estão sempre associadas e, em alguns casos, já foram absorvidas por multinacionais de origem norte-americana, europeia, chinesa, que constroem os mesmos equipamentos em outros polos mundiais de offshore, como Singapura e Coreia do Sul. 


\section{Refinarias, Grandes Focos de Poluição e de Riscos}

A etapa final da produção petrolífera, chamada de 'refino do petróleo', consiste na separação das frações de hidrocarbonetos distintos que compõem os vários tipos de petróleo. Isso porque cada poço, em cada época da sua produção, gera um tipo diferente de óleo cru, com diferentes proporções entre os compostos, com diferentes teores de água de formação, de sais, de compostos nitrogenados, de enxofre, de mercúrio, cádmio e outros metais pesados. Portanto, a lógica do processo industrial das refinarias é produzir, em diferentes faixas de aquecimento - vaporização e condensação -, cada um dos derivados, cujas características técnicas e comerciais são padronizadas (gás de cozinha, querosenes, gasolinas, naftas, óleos tipo diesel e óleos mais viscosos), partindo de uma matéria-prima que não é sempre exatamente igual.

Apesar do nome no singular - a refinaria -, cada uma delas é um verdadeiro complexo industrial com grandes parques de armazenamento e várias 'fábricas', nas quais passa o fluxo de óleo cru. As principais são: dessalgadoras; destilarias que funcionam com a pressão atmosférica e a vácuo; reatores de craqueamento catalítico e de coqueificação de resíduos, que, nesse caso, gera um combustível sólido similar ao carvão mineral. Todas essas instalações são equipadas com fornos de aquecimento dos fluxos líquidos, onde são queimados combustíveis obtidos de uma fração do próprio petróleo processado e, em alguns casos, do gás natural.

Todo o conjunto depende de um grande consumo de água: aproximadamente 1:1 em volume, ou seja, para cada litro de petróleo processado, utiliza-se um litro de água bruta. Usa-se parte dela no processo industrial, resultando em um grande volume de efluentes líquidos oleosos e contaminados que devem ser tratados em estações especialmente projetadas e operadas. Outra parte da água é supertratada para entrar nas caldeiras e produzir vapor, utilizado também no processo industrial e na movimentação de turbinas nas chamadas 'centrais de utilidades industriais'. Nas centrais, que funcionam como o núcleo vital desse conjunto de fábricas, as caldeiras também queimam óleos residuais e gás natural, e costuma haver também turbinas a gás para produzir eletricidade em grande quantidade, com potências instaladas de dezenas de milhares de quilowatts. No circuito de vapor, que precisa ser continuamente condensado para ser reutilizado, grandes torres de resfriamento provocam uma perda considerável da água por evaporação, que pode chegar à terça parte do total da água utilizada.

A queima de grandes volumes de óleo combustível e gás natural em fornos, caldeiras e turbinas resulta, logicamente, nos vários produtos de 
combustão: fumaça, cinzas, gases carbônicos, nitrogenados e sulfurosos que, exceto em alguns casos nos quais atuam equipamentos neutralizadores, são lançados na atmosfera. O balanceamento de gases e produtos voláteis dentro do processo exige também que fiquem sempre acesas as altas tochas de alívio, onde são queimados esses 'excessos' de produtos não comerciais ou oriundos de desarranjos operacionais.

Os grandes tanques de armazenamento de petróleo cru e de derivados já fabricados, apesar dos dispositivos de selagem e proteção, também permitem que uma parte dos hidrocarbonetos voláteis saia para a atmosfera próxima como emanação contínua e variável, sem, no entanto, queimar. Esse somatório de resíduos e vapores inflamáveis lançados na atmosfera faz com que cada refinaria se constitua numa importantíssima fonte fixa de poluentes do ar. Geralmente, as refinarias são a fonte com maior risco nas regiões onde se localizam.

As maiores refinarias ficam nos estados de São Paulo (Paulínia, São José dos Campos e Cubatão); do Rio de Janeiro (Duque de Caxias); da Bahia (Mataripe); do Paraná (Araucária); de Minas Gerais (Betim); e do Rio Grande do Sul (Canoas). Outras refinarias menores funcionam no Rio Grande do Sul (Rio Grande); em plena área urbana dos municípios do Rio de Janeiro (Manguinhos) e de Santo André (Capuava), além de Manaus e Fortaleza. Em Pernambuco (no distrito de Suape, Jaboatão), uma nova refinaria de grande porte está sendo construída, com previsão de entrar em operação no final de 2014, e duas outras são anunciadas para Pecém (CE) e para a Baixada Maranhense. Nesses três casos, os conflitos ambientais e sociais se acumularam nos últimos anos nas localidades escolhidas, mesmo antes de as indústrias entrarem em operação.

Um dos casos de maior repercussão nos últimos anos continua se desenrolando no norte e nordeste da baía da Guanabara, profundamente alterada pela implantação, no município de Itaboraí, do complexo petroquímico, que inclui uma refinaria de petróleo, o Complexo Petroquímico do Rio de Janeiro, conhecido como Comperj. Acopladas a esse investimento, às ampliações da produção na bacia de Campos e na área da Refinaria de Duque de Caxias (Reduc), outras obras têm sido feitas nas ilhas situadas na baía de Guanabara, com o objetivo de aumentar os terminais de derivados de petróleo e abrir um novo terminal de gás natural liquefeito (GNL) importado. Para tanto, têm sido instaladas mais linhas submarinas de gás e de derivados, o que provocou um aumento das áreas de restrição à pesca na baía, além de sequelas nas praias do município de Magé, onde a maior parte 
dos moradores é dependente da pesca artesanal e empresarial e é bastante prejudicada com as obras.

Esse conflito chegou a envolver práticas de violência ainda não esclarecidas, como um assassinato e ameaças contra dois pescadores e membros da direção da Associação Grupo Homens do Mar. O último caso de ameaças foi incluído no programa de proteção das vítimas de violência, conforme pode ser visto no Mapa de Conflitos. Esse caso envolve outras consequências previsíveis, como o sacrifício de uma parte da integridade da maior área contínua de manguezais em toda a orla da baía de Guanabara. Com cerca de 80 km², esses manguezais, cuja vegetação ainda está quase íntegra, estão contidos na Área de Proteção Ambiental de Guapimirim.

Os rios Guapimirim, Macacu, Caceribu e Guaxindiba, que são contíguos e que deságuam na baía, apesar de terem trechos bastante alterados por retificações e canalizações realizadas na época das obras do antigo Departamento Nacional de Obras de Saneamento (DNOS), ainda não foram totalmente destruídos nem contaminados. Porém, dois deles, Macacu e Caceribu, já recebem material erodido das obras do Comperj e, no futuro, receberão as águas pluviais contaminadas e os efluentes industriais do complexo.

\section{Gasodutos e Usinas Termelétricas a Gás}

Gasodutos extensos e de bitola grande são megainvestimentos recentes no panorama industrial brasileiro. Em poucas décadas, de 1970 a 1990, montou-se um poderoso esquema para o escoamento do gás do mar norte fluminense em direção à cidade do Rio de Janeiro, e se estruturou uma linha quase contínua de tubos entre a região produtora dos litorais do Ceará e Rio Grande Norte até o Rio de Janeiro, ramificando-se para o interior de Minas Gerais e de São Paulo. ${ }^{4}$

No final da década de 1990, entrou em operação uma das maiores articulações da indústria energética mundial, o gasoduto Bolívia-Brasil (Gasbol), iniciativa de um consórcio envolvendo, entre outras empresas, a Petrobras, a Shell e a mal-afamada Enron. Esta multinacional, de origem norte-americana, poucos anos depois, mergulhou o estado da Califórnia em terríveis racionamentos e aumentos de preços de eletricidade e desapareceu em meio a golpes fraudulentos à custa de pequenos acionistas e funcionários.

\footnotetext{
${ }^{4}$ Cabe lembrar o desastre em Vila Socó, Cubatão, em fevereiro de 1984, decorrente do vazamento de 700 mil litros de gasolina num gasoduto da Petrobras, seguido de incêndio onde morreram oficialmente 98 pessoas, mas estimativas do Ministério Público indicam mais de seiscentos mortos (Freitas, Porto \& Machado, 2000).
} 
O fluxo de gás partia da região produtora perto da fronteira BolíviaArgentina-Paraguai, centralizando o bombeamento em Santa Cruz de la Sierra e se bifurcando em um ramal menor para Cuiabá, no Mato Grosso, com a finalidade de alimentar uma termelétrica da Enron na capital matogrossense, que iniciou a operação em 2002 e paralisou em 2009. O outro tronco, o Gasbol, de grosso calibre, segue para leste em direção a Corumbá, Campo Grande e Três Lagoas, no Mato Grosso do Sul, de onde seguiu para o entroncamento de Paulínia, em São Paulo.

A lógica do anúncio de investimentos em novas usinas termelétricas a gás parece ser a tentativa de garantir que uma boa parte do gás a ser despachado das regiões produtoras seja queimado em poucos e grandes clientes preferenciais instalados no traçado do gasoduto, como se fossem as 'lojas-âncora' dos centros comerciais. O que faz muito sentido, já que uma usina com capacidade de $250 \mathrm{MW}$, funcionando de modo eficiente com ciclo combinado (turbinas a gás e turbinas a vapor), pode queimar até 1 milhão de metros cúbicos por dia ( $\left.\mathrm{m}^{3} / \mathrm{dia}\right)$. Assim, um grande gasoduto, com capacidade de transporte de 30 milhões $\mathrm{de}^{3}$ /dia como o Gasbol, poderia se tornar viável caso entrassem em funcionamento uma dúzia de termelétricas desse porte ou, de preferência, algumas um pouco mais possantes.

Outra característica notável do anúncio desses projetos de usinas é que os grupos econômicos que os anunciam são, em geral, consórcios com um sócio brasileiro mais conhecido e os demais são 'arrivistas', grupos sem experiência no setor, e outros estrangeiros que tentam, assim, posicionar-se em um atraente mercado, que é a eletricidade brasileira pós-privatização, consumada em poucos anos durante os governos de Fernando Henrique Cardoso, entre 1995 a 2002.

Foi exatamente essa combinação de fatores que desencadeou, entre 1998 e 2003, uma onda impressionante de projetos de novas usinas ao longo do gasoduto Bolívia-Brasil e outras ao longo dos gasodutos do Nordeste e do Rio de Janeiro. Tais usinas representariam, caso fossem construídas, focos poderosos de emissão de poluentes atmosféricos, especialmente os hidrocarbonetos e os gases de nitrogênio, que fariam aumentar a concentração de gás ozônio respirável, além de consumirem volumes impressionantes de água para a condensação do vapor quando operassem em regime de ciclo combinado.

O governo federal havia lançado, no início da década de 2000, um programa prioritário de termelétricas que previa a construção, a curto prazo, de quase cinquenta novas usinas, quase todas a gás natural. De tudo o que 
foi anunciado naquele período, apenas uma parte delas chegou a abrir um processo correto de licenciamento ambiental e, dessas, muitas nem chegaram a completar a etapa de audiências públicas. Outras completaram, mas desistiram de prosseguir com os investimentos porque haveria aumento de custos para se minimizar a poluição e o uso de água, ou porque houve desentendimentos comerciais com as empresas que forneciam o gás. Ao final, bem poucas foram licenciadas e efetivamente construídas.

Passaram para a memória regional em São Paulo as batalhas de entidades, pesquisadores e uns poucos políticos contra a instalação de projetos de usinas termelétricas de grande porte naqueles anos da passagem dos séculos. Fracassaram, entre outros, os projetos de usinas em Jundiaí, Paulínia, Americana, Araraquara, Santa Branca, Mogi Guaçu, nas cidades do ABC, em Cubatão - onde afinal vingou um projeto de menor porte feito posteriormente dentro da Refinaria de Presidente Bernardes (RPBC). Por ironia, um projeto de 400 MW de potência queimando gás foi licenciado e construído pela Petrobras em um dos locais mais poluídos da própria cidade de São Paulo, no bairro de Interlagos, onde já funcionava, há décadas, a velha usina térmica de Piratininga. Entretanto, nos últimos anos, ela tem funcionado com uma média de $15 \%$ dessa capacidade, conforme dados constantes do site do Operador Nacional do Sistema (www.ons.org.br).

Um projeto anunciado em 2010 é vinculado a um novo gasoduto que entrou em operação em 2011, o Gastau. Este liga os poços no alto mar, ao largo da Ilha Bela, a uma UPGN, em Caraguatatuba, que se estende até Taubaté, onde se conecta ao gasoduto Campinas-Rio de Janeiro. Nesse traçado, fica a pequena cidade de Canas, vizinha de Lorena, no Vale do Paraíba do Sul, onde se anunciou um projeto de usina a gás com $550 \mathrm{MW}$ de capacidade, pela mesma empresa norte-americana AES, que há dez anos havia desembarcado para fazer uma megacentral em Santa Branca, também no Vale do Paraíba do Sul, mais a oeste.

O gasoduto Gastau envolveu, entre 2008 e 2010, uma complexa obra de engenharia para garantir o transporte de um dos maiores fluxos de gás natural do país, da ordem de 20 milhões de $\mathrm{m}^{3} /$ dia, e ao mesmo tempo para diminuir os problemas ambientais e os riscos no trecho de $96 \mathrm{~km}$ na Serra do Mar entre a UPGN da praia da enseada, em Caraguá, e a cidade de Taubaté. Esse gás vem do mar, da plataforma de Mexilhão, já em operação, e se somará aos fluxos provenientes das demais plataformas daquela região offshore: Lula, a $225 \mathrm{~km}$ de distância, e Uruguá-Tambaú, a $174 \mathrm{~km}$. Em terra firme, as localidades ao longo do escoamento desse gás do pré-sal da bacia 
de Santos, sofrerão, como atualmente acontece em Canas, uma crescente pressão empresarial para serem feitas mais usinas térmicas a gás.

Outra região onde as sequelas da chegada do gás natural estão despontando e parece que vão permanecer por um longo tempo é o litoral sul da Bahia, onde, na bacia de Camamu, alguns poços já o produzem, desde 2007, em uma associação entre a Petrobras, a Queiroz Galvão e a norte-americana El Paso. A mesma Queiroz Galvão iniciou recentemente a produção em frente à foz do rio Jequitinhonha, em poços localizados a $30 \mathrm{~km}$ da costa. Toda a faixa litorânea da Bahia, em especial o sul, entre Ilhéus e Caravelas, entrou em ebulição de obras e de prospecções: inicialmente com a construção e operação do oleoduto de derivados entre o Recôncavo Baiano e Itabuna, e posteriormente com a conclusão do tronco litorâneo de gasoduto que interliga as regiões produtoras do Nordeste, do Espírito Santo e do Rio de Janeiro.

Os problemas com o turismo e com os moradores litorâneos, a maioria pescadores e marisqueiros, devem-se multiplicar com o avanço das prospecções em toda a faixa litorânea, incluindo-se o entorno do arquipélago de Abrolhos, local excepcional de migração e reprodução de vida marinha e de aves. Até aqui supúnhamos que Abrolhos estivesse protegido pela existência de um parque nacional marinho, mas os seus limites e estatutos estão sob fogo cerrado da indústria petrolífera, cujo objetivo é finalmente violar os critérios de conservação integral e permitir mais um desembarque da indústria toda-poderosa.

Ampliou-se também a indústria petrolífera na Amazônia, cujo núcleo inicial no rio Urucu, desde 2011, abastece Manaus com gás natural para as grandes termelétricas que suprem a capital amazonense - após vários anos de obras na várzea do rio Solimões. Pode-se prever também a multiplicação das situações de conflitos por causa da ampliação de prospecções na bacia do rio Juruá, na região de Carauari, subindo nesse vale até o estado do Acre, onde as atividades petrolíferas já foram iniciadas e poderiam atingir várias terras indígenas, reservas extrativistas e o Parque Nacional da Serra do Divisor. Também nos municípios próximos a Manaus e ao rio Amazonas, até a fronteira com o Pará, foram recentemente licitados alguns 'blocos' para a atividade de prospecção petrolífera. ${ }^{5}$

Assim parece prosseguir essa indústria, em sua faina interminável de suprir a economia e todos nós com os derivados de petróleo, dos quais

\footnotetext{
${ }^{5}$ Mais detalhes podem ser obtidos em Sevá e Iglesias (2007).
} 
nos tornamos dependentes. Porém, está sempre cuidando de garantir lucros crescentes e um poderio raramente igualado na história, formando verdadeiros reinos autocráticos dentro de Estados de aparência democrática e republicana.

\section{Consequências da Operação de Usinas Hidrelétricas e dos Investimentos em Novas Usinas}

As usinas hidrelétricas, apesar de toda a propaganda que as apresenta como fontes de energia limpa e renovável, embora tenham vantagens genéricas sobre as usinas termelétricas, ocasionam, antes, durante e depois da sua construção, na fase operacional, problemas sociais, ambientais e de engenharia propriamente ditos bem mais sérios para que possam caber na expressão administrativa 'impactos'.

Entre as complicações operacionais mais frequentes das usinas, estão certas consequências desastrosas ocasionadas por manobras de fechamento de comportas no primeiro enchimento da represa, e nas paradas e partidas de turbogeradores. Como comprovação disso, no Brasil, observamos verdadeiros antiexemplos.

O rio Tocantins ficou seco por dezenas de quilômetros durante semanas seguidas, em 1998, quando as empresas VBC e Furnas fecharam as comportas da usina Serra da Mesa, em Goiás; rio abaixo, no mesmo Tocantins, na usina Lajeado, no estado do Tocantins, quatro anos depois, em 2002, uma mortandade de peixes jamais vista ocorreu a jusante da barragem. Nesse mesmo tempo, na represa, a principal praia foi interditada por motivos sanitários; nove anos depois, em 2011, verificou-se outra mortandade na usina de Estreito, fronteira Tocantins-Maranhão. Em 1988, uma mortandade humana ficou pouco conhecida, abafada pela Companhia Hidro Elétrica do São Francisco (Chesf): 88 pessoas faleceram com diarreia aguda, entre as 2.392 pessoas intoxicadas, residentes na beira da represa recém-formada da usina de Itaparica, que alagou municípios da Bahia e de Pernambuco, sepultando a cidade de Petrolândia (PE). As pessoas intoxicadas contraíram hepatotoxicoses por causa da ingestão ou contato com a água da represa, em locais próximos à antiga cidade submersa poucos dias antes, sem as devidas medidas de limpeza e descontaminação de esgotos, fossas e cemitério. Análises da água provaram a concentração de algas pigmentadas e de cianobactérias Anabaena e Mycrocistis (Confalonieri et al., 2002).

Para os que são cientistas no sentido pleno, investigadores da realidade e de suas contradições, a situação atual, após o surto de mais de um século 
das usinas hidrelétricas, foi radicalmente alterada. Trata-se de rupturas e violações: a destruição dos monumentos fluviais mais maravilhosos do planeta; a acumulação primitiva de capital, fundada na expropriação dos pobres e dos nativos; a especulação e a concentração fundiária de milhares de hectares a cada represa.

A implantação de usinas hidrelétricas nos rios e terras ribeirinhas se constitui, no mundo todo, em um campo de disputas por terrenos e posições geográficas, e resultam em reordenamentos fundiário e agrícola das regiões onde são implantadas. Dada a sua dimensão técnica, econômica e territorial, tornam-se fatores de desorganização social e econômica, com expulsão de grande parte das populações residentes, à qual se segue uma reorganização baseada em novas atividades que se estabelecem no entorno da represa. Tais temas são pesquisados atualmente por cientistas sociais, geógrafos, antropólogos, além de economistas e agrônomos no Brasil e em todo o mundo, dentre os quais destacam-se Patrick McCully (2004), Arsênio Oswaldo Sevá Filho (2005, 2008a), Andreia Zhouri, Klemens Laschefski e Doralice Pereira (2005) e Franklin Rothman (2008).

Não deveria haver surpresa com tal caráter conflituoso das hidrelétricas, na medida em que, nas civilizações passadas, as terras ribeirinhas e o uso dos rios foram fatores de disputas entre grupos sociais e focos de conflitos de interesses econômicos e estratégicos. E continuam sendo. O que há de novo é que os rios, a água e as terras ribeirinhas também têm sido conquistados pela indústria barrageira, para serem 'geridos' com base em critérios da mercadoria eletricidade. As dimensões das maiores represas agora podem alcançar centenas de milhares de hectares de superfície, mas a maioria delas tem dezenas de milhares. O remanejamento fundiário atinge também as áreas ocupadas por canteiros de obras e respectivos serviços, alojamentos e pequenas fábricas acopladas, mais as estradas de serviço, as glebas de onde se retira madeira, areia, pedra, seixos, a faixa das linhas de transmissão.

Por tudo isso, não é adequado definir os processos sociais e territoriais das hidrelétricas em jogo como 'impactos', uma expressão meramente administrativa para designar os processos de licenciamento ambiental. É uma expressão contraproducente, desviacionista no âmbito do conhecimento, da ciência, e também quando se trata da mobilização das populações expropriadas e atingidas na defesa de seus direitos e reivindicações. Nos casos em que esses grupos passam a se autodenominar 'impactados', já existe uma 'derrota semântica', uma enorme concessão ideológica ao esquema formal de licenciamento ambiental - que nunca teve nem terá qualquer pretensão 
de resolver ou amenizar o drama humano, nem a regressão política que cada hidrelétrica desencadeia.

As megaobras e mesmo as pequenas, que alguns chamam, positivamente, de 'pequenas centrais', devem ser analisadas como campos de ação dos interesses de classes e de grupos sociais. Cada cenário de implantação de um projeto hidrelétrico deve ser visto como um campo de disputas em que há excelentes oportunidades de lucros e de exercício de poder em âmbito extralocal e extranacional, combustível clássico da cadeia financeira e produtiva da obra, ao mesmo tempo nas duas pontas do empreendimento: a de fornecimento durante a construção da central e das linhas de transmissão, e a de despacho de eletricidade depois de pronta e operacional, ou seja, na etapa de avanço de capital e na fase de realização da mercadoria a ser produzida no mercado de energia.

Dentre tais competições e coligações de interesses distintos, chamamos especialmente a atenção para uma série de disputas prévias relacionadas ao próprio projeto: onde será feito? Quem contratará serviços? Quem será empregado? Quais as cotas (altitudes) e locais atingidos? Uma 'peste moral' começa a se instalar: a boataria deliberada, em parte incontrolável, sobre as indenizações e preços de aquisição de glebas de terra e de benfeitorias, sobre o licenciamento, sobre as possíveis compensações. Ocorre uma transformação radical, vivida também em outros locais e em outros tempos da história, expressa por uma sequência na qual podemos entrever a acumulação primitiva capitalista; um tipo de espasmo rápido e intenso que perdura por vários anos no caso de obras menores e por uma ou duas décadas no caso das maiores.

Porém, a construção de hidrelétricas é mais do que uma fase pioneira; é a continuidade do processo histórico capitalista. As grandes obras vão demarcando os ciclos de acumulação ao longo dos quase três séculos em que persiste esse sistema político e econômico. Inicialmente ferrovias, estaleiros e portos, canais, pontes, túneis, em seguida as barragens, os grandes eixos de transporte e de comunicação, as megafábricas, refinarias, montadoras de veículos e de aparelhos. E, como a dominação é sempre também política, boa parte desses surtos e ciclos de grandes empreendimentos é baseada em informação privilegiada. Alguns sabem antes dos demais qual a posição do eixo do barramento no ponto preciso do rio, que terrenos serão afogados e até que cota de altitude.

A acumulação de capital em poucas mãos se realiza por meio de negociações entre partes desiguais; são muitos os que acabam prejudicados. 
Mas são individualmente fracos, envolvidos a contragosto em transações forçadas. Pessoas, famílias e até cidades inteiras são objetos de logro, traição e ameaças. Informação privilegiada, desigualdade notável nas negociações, poder de fogo, essas são marcas de um processo conhecido como acumulação primitiva, com os métodos típicos da expropriação de bens materiais e simbólicos das pessoas e da espoliação de comunidades, aldeias, etnias.

Do lado dominante, são poderosos os meios de execução das ações. Como impedir que uma carga de explosivos detone uma laje rochosa se isso já está programado e decidido? Quem resistirá a uma motoniveladora que está arrasando um pomar e uma casa, cujos donos não puderam fazer valer sua recusa? Quem modificará o fechamento ou a abertura de uma comporta cuja operação está secando o rio a jusante ou, ao contrário, está baixando o nível da represa? Nesses casos, a operação da usina provoca prejuízos sérios para os agricultores e outras atividades beira-rio e 'beirarepresa'. Mas o que os atingidos podem fazer quando essas manobras técnicas operacionais vêm determinadas por um corpo gerencial de despachantes - vendedores de eletricidade operando no Rio de Janeiro ou em Brasília?

Projetos que alteram para sempre a vida de cidades inteiras, alagando-as ou deixando-as secas no trecho do rio, deveriam ser banidos em qualquer sociedade mais adiantada, mas, na nossa, infelizmente, prosseguem sem qualquer restrição. Um dos últimos absurdos dessa natureza foi o barramento em 2007 do baixo rio Doce, entre os municípios de Aimorés e Itueta (MG) e Guandu (ES). Obarramento colocou a primeira cidade diante do esqueleto do grande rio que sempre passou em frente de sua avenida Beira-Rio, sepultou totalmente a segunda cidade e tornou necessária a construção de uma 'nova' Itueta longe do rio, com traçado de prancheta, pretensamente moderna, mas, na maior parte, desocupada e sem vida. ${ }^{6}$

A cada canteiro de obras, são introduzidos 'para sempre' novas noções e novos valores da mercantilização, pois terras, benfeitorias e patrimônios passam a ser vistos apenas como dinheiro e, por fim, ocorre a mercantilização da própria força de trabalho e de muitas relações sociais. O investimento em si, o avanço de capital nas contratações e nas compras de insumos, cria novas oportunidades de negócios, assanhando as contas feitas nos gabinetes das direções financeiras e industriais. Dentro do alambrado, dentro das guaritas, a nova lógica é o assalariamento de grandes contingentes, e, assim, em poucos

\footnotetext{
${ }^{6}$ Como pude constatar quando estive na cidade poucos meses após a 'inauguração' do consórcio formado entre duas das maiores empresas do mundo, cada uma em seu setor: a elétrica Cemig e a mineradora Vale. Mais detalhes podem ser obtidos no site do Mapa de Conflitos.
} 
anos, já existem os ingredientes básicos de uma sociedade organizada em torno de empresas capitalistas.

Esse processo pode ser, a cada época, novamente observado no Brasil, atualmente especialmente em Chapecó e locais vizinhos na fronteira entre Santa Catarina-Rio Grande do Sul; em vários municípios da fronteira Tocantins-Maranhão; e em Porto Velho, capital de Rondônia. Essas áreas têm experimentado, nos últimos anos, a 'viagem' da excepcionalidade transformada em normalidade cotidiana, decorrente da implantação das megaobras no rio Uruguai (Usina Foz do Chapecó), no rio Madeira (Usinas Santo Antônio e Jirau), e no rio Tocantins (Usina do Estreito). Todas essas obras são valiosas 'prendas' recentes dos principais grupos nacionais e internacionais da indústria barrageira e elétrica, as quais mais uma vez exerceram influência sobre as populações e movimentos fazendo uso da sua conhecida dosagem de propaganda e contrainformação, de cooptação e repressão. Nesses casos, claramente foram rebaixados os custos de aquisição das terras e propriedades que seriam destinadas para as obras ou para o alagamento do reservatório. Isso comprova a nossa interpretação: o método de acumulação primitiva está presente nesses empreendimentos.

Em todos os casos, especialmente em Foz do Chapecó e no Estreito, as empresas pressionaram os moradores para que não insistissem com reassentamentos e aceitassem como forma de indenização as cartas de crédito, uma espécie de 'cheque-despejo'. Esse tipo de indenização está muito em voga nas expulsões que ocorrem nas maiores cidades em razão das obras da Copa do Mundo de Futebol.

Para essas cartas de crédito, os valores fixados da terra e das construções eram decididos antes de qualquer processo administrativo de negociação coletiva, e mesmo a concessão de benfeitorias, como árvores frutíferas, colheitas futuras, galpões, cercas e pontes, só foi admitida quando se intensificaram as reclamações.

Até mesmo no caso do Estreito, essa mesma pressão insidiosa foi exercida sobre as famílias anteriormente assentadas em projetos do Instituto Nacional de Colonização e Reforma Agrária (Incra). Elas não tiveram direito garantido ao reassentamento e viram o seu órgão de tutela, o Incra, fazer abertamente o jogo dos empreendedores, os poderosos representantes do capital barrageiro internacional: Alcoa, Vale, Tractebel, Camargo Correa. Esse foi o resultado do doloroso processo de 'negociação' entre os assentados do Projeto Formosa, os representantes do Incra, do Ministério Público Federal e das empresas, como revela o relatório de pesquisa de Neila Soares da Silva (2010). 
Portanto, nos estudos e pareceres guiados pela razão hidrelétrica cega, os cidadãos prejudicados e os patrimônios naturais e construídos, devastados por causa das obras, são geralmente vistos como 'interferências' em seus empreendimentos. Esses cidadãos atingidos, com posses e direitos, que devem ser respeitados, e os patrimônios, que devem ser defendidos, são considerados um 'entrave' para a cultura desenvolvimentista brasileira.

\section{Façanhas do Fundamentalismo Barrageiro: saída para a crise global, leilões, $\mathrm{PCHs}$, a persistência até a 'vitória'}

Continua a forte a pressão pelo barramento de todos os rios, de todos os pontos barráveis de todos os rios que sejam considerados fontes de lucro. A articulação de forças para se conseguir tal empreendimento é de alcance internacional e, de certo modo, todo o capitalismo global elegeu o aproveitamento do dito potencial hidráulico dos rios brasileiros como uma meta prioritária, uma verdadeira 'tábua de salvação' para um sistema econômico em crise profunda. Realizar tais projetos no Brasil seria uma alavanca indiscutível nessa busca desesperada por investimentos com excepcionais volumes de encomendas de máquinas e materiais e com previsão de altíssimas taxas de lucro (Sevá Filho, 2011).

O núcleo visível desse 'fundamentalismo barrageiro' inclui a esfera federal, o Ministério de Minas e Energia e a sua empresa de pesquisa energética, que representa um verdadeiro enclave das empresas de consultoria e projetos dos grandes grupos econômicos dentro do governo, e também as duas agências ditas reguladoras que foram criadas em pleno 'carnaval' privatizante dos governos de Fernando Henrique Cardoso: a Agência dos Negócios da Energia Elétrica (Aneel) e a dos negócios da água, Agência Nacional das Águas (ANA), cujas iniciativas e decisões têm se mostrado totalmente afinadas com as pretensões dos grandes grupos econômicos, alguns brasileiros e, a maioria, multinacionais.

Leilões dos rios e trechos de rios barráveis são feitos, alguns a cada ano, sem interrupção, desde a criação da Aneel em 1998, sob o pretexto de que a agência estaria, dessa forma, 'antecipando' a concretização dos aumentos de oferta de eletricidade em benefício de todo o país. Na realidade, estão forçando a licitação de um número de projetos bem maior do que seria necessário de acordo com as projeções mais infladas de aumento de consumo de energia e colocando em leilão mais projetos do que seria possível, considerando-se a complexidade e a responsabilidade que deveriam marcar a elaboração técnica dos projetos de engenharia, os estudos de viabilidade econômica e os 
próprios processos de licenciamento. Na verdade, a programação dos leilões acaba por encurralar, sabotar, ou 'agilizar' - como eles gostam de dizer - o licenciamento ambiental.

Por exemplo, no leilão de energia nova (tipo A-5), realizado em dezembro de 2011, a Aneel anunciou meses antes que seriam licitadas 13 usinas com uma potência somada de 2.792 MW. Dos 13 projetos de usinas, cinco previam um único rio, o Parnaíba, na fronteira Piauí-Maranhão, com uma soma de 460 MW. Eles seriam apresentados em 'único lote' - as usinas de Castelhano, Estreito, Cachoeira, Uruçuí e Ribeiro Gonçalves -, uma clara tentativa de tornar irreversível o aproveitamento integral do rio, onde apenas uma única obra de grande porte, a usina Boa Esperança, causou traumatismos sociais e fundiários memoráveis há quarenta anos, em plena época ditatorial. Os projetos no rio Parnaíba, desde que foram anunciados há alguns anos, provocaram grande reação em pequenas cidades ribeirinhas da região, na medida em que alagariam as poucas terras aluviais férteis nas margens do rio principal e de todos os afluentes em um longo trecho. Na prática, parecem desvinculadas de algum plano regional de eletrificação e também não atendem a medidas de promoção do desenvolvimento regional há tempos reclamadas. Ou seja, apenas são 'oportunidades de negócios' para grandes grupos que desembarcariam em regiões pobres e supostamente despreparadas para resistir a essa ofensiva.

Na mesma ocasião, seria leiloado um projeto bastante controvertido e que, talvez, não devesse nunca ser feito, o de Riacho Seco, que barraria o único trecho do médio São Francisco que ainda corre, na divisa Bahia-Pernambuco, entre as usinas de Sobradinho e de Itaparica, trecho já castigado pelo avanço das obras da famosa 'transposição' da vazão do rio. Além disso, esse leilão teria o objetivo de prosseguir com a blitz barrageira na bacia do Tapajós matogrossense, forçando a mesma ideia de um 'complexo de usinas' no rio Teles Pires, com o novo projeto da usina Sinop (400 MW), além de São Manoel (700 MW) e Foz do Apiacás (275 MW), com sérias consequências para os povos indígenas da região. Essa blitz também afetaria a bacia do Araguaia, em Mato Grosso, agora na bacia ainda 'virgem' do rio das Mortes, com os projetos Água Limpa (320 MW) e Toricoejo (76 MW). Para completar o 'vespeiro' armado pela Aneel nesse leilão, será forçada a inclusão de obras cujo licenciamento está bastante atrasado, justamente em virtude de pendências de outras obras muito próximas: a de Davinópolis (107 MW), na bacia do Paranaíba, divisa Goiás-Minas Gerais, e a de São Roque (214 MW), na bacia do rio Uruguai em Santa Catarina, cuja licença por parte da agência ambiental 
catarinense parece depender do equacionamento dos problemas já ocorridos rio abaixo com o projeto Garibaldi. ${ }^{7}$

Contrariamente ao que tem sido propagandeado pelas empresas interessadas e também por várias entidades ambientalistas, as usinas apresentadas como pequenas centrais hidrelétricas ( $\mathrm{PCHs}$ ) não estão isentas de causar problemas sociais e ambientais na sua implantação. De certa forma, podem ser ainda piores do que as usinas convencionais de médio e grande portes, já que sua implantação não depende de licitações, e sim de meras autorizações da Aneel, ou seja, dependem da obtenção de informações privilegiadas em Brasília. Além de receberem muitas facilidades de financiamento, de aquisição da eletricidade futura pela Eletrobras e uma verdadeira dispensa de formalidades de licenciamento, já que não precisam elaborar estudo de impacto ambiental, nem se submeter aos rituais de audiência pública. Por tudo isso, tornaram-se, para os empresários, uma verdadeira 'mina de ouro', e, para as populações de muitas regiões brasileiras, uma verdadeira 'praga'.

As chamadas PCHs, ao serem implantadas, desencadearam problemas em vários locais. Entre os mais conhecidos, citam-se o rio Tijuco, no Triângulo Mineiro, perto de Ituiutaba; o rio Aiuruoca, logo acima da cidade de Aiuruoca (MG); e o entorno do Parque Estadual da Serra do Papagaio, no rio Mucuri, perto da cidade de Carlos Chagas (MG) e da divisa com o Espírito Santo. Algumas tiveram a intenção explícita de fustigar os povos indígenas, pois foram projetadas em cima ou muito próximo de suas terras ancestrais, abrindo o caminho para novos conflitos com vários deles. No caso de Mato Grosso, são vários os exemplos presentes no Mapa de Conflitos: os Xavante, com a usina Paranatinga no rio Culuene, formador do Xingu; os Enawene Nawe no alto rio Juruena, perto de Sapezal, com vários projetos de interesse direto da família Maggi, do ex-governador do estado; os Pareci, na localidade de Ponte de Pedra, entre outros.

As PCHs, além de não serem necessariamente pequenas, podem causar grandes alterações no rio e nas terras marginais. Bons exemplos de danos causados por esse tipo de empresa são as usinas de Cachoeira Paulista e Queluz (SP), ao lado da via Dutra, prontas depois de intensas e rápidas obras. Essas usinas foram construídas no rio Paraíba do Sul pelas multinacionais Alusa e Alstom, com grande intervenção nos morros da margem direita do

\footnotetext{
${ }^{7}$ Mais detalhes desses conflitos podem ser obtidos no site do Mapa de Conflitos e na matéria"Treze usinas voando" da revista Brasil Energia (Treze usinas, 2011).
} 
rio para ser suspenso por alguns metros um trecho de vários quilômetros de ferrovia da antiga Central do Brasil, agora operada pela MRS Logística, controlada por empresas mineradoras e siderúrgicas como a Vale e a CSN.

Para os arautos da ideologia dominante, à direita e à esquerda, o dogma do barramento de todos os rios, com o aproveitamento total do que eles chamam de 'potencial hidrelétrico', prevê implementação cotidiana, sem descanso, uma persistência até a 'vitória'. Basta lembrar o caso do projeto Belo Monte, que foi duas vezes derrotado, em 1989 politicamente pela repercussão negativa do Encontro dos Povos Indígenas do Xingu realizado em Altamira, e pela retirada do financiamento multilateral; e, em 2001, juridicamente pelas denúncias de vício e irregularidade do processo de licenciamento ambiental.

As forças políticas de esquerda, que apoiavam Luiz Inácio Lula da Silva e que ajudavam o movimento contrário ao projeto no Pará, mudaram de lado ostensivamente com a campanha presidencial de 2002. Dez anos depois, elas se juntam a vozes conservadoras, como a do ex-ministro Delfim Netto, para, mesmo depois de realizarem o leilão de eletricidade e de obterem as licenças ambientais, manterem uma campanha sistemática de demonização dos grupos contrários e insatisfeitos com o projeto. Simplesmente atribuem tudo ora à enfraquecida oposição partidária ao lulismo, ora aos indígenas que teriam 'muita terra para pouca gente', às organizações ambientalistas estrangeiras que defendem interesses em não permitir 'que o país se desenvolva', e a outros maniqueísmos similares.

Um aspecto pouco lembrado, mas que, em parte, explica a afoiteza, a pressa em implantar algumas hidrelétricas em rios da Amazônia, é a possibilidade de, durante as obras, serem mineradas as terras e rochas do fundo dos rios e das barrancas em locais sabidamente auríferos. É o caso das duas usinas no rio Madeira, feitas exatamente em trechos dos mais garimpados nas últimas décadas; é também o caso do Projeto na Volta Grande do Rio Xingu (Belo Monte). Mas, principalmente, seria o caso das várias obras previstas no rio Tapajós acima da cidade de Itaituba (São Luís da Cachoeira) e no seu afluente Jamanxim. Provavelmente foi a existência de ouro nos locais projetados que motivou a ideia recentemente anunciada de se fazer as usinas no interior da selva como se fossem as plataformas petrolíferas no meio do mar: transformar os canteiros de obras em verdadeiras ilhas cercadas, sem alojamentos definitivos para muita gente, levando e trazendo trabalhadores de helicóptero e avião para impedir as populações de chegarem próximo e criarem vilarejos e bairros, e para manter todos à distância, antes, durante e depois das obras. 


\section{Os Investimentos e a Política Global: militarização e retrocesso}

A vida política, em sua forma mais visível, parece ser explicada pelo jogo dos partidos, cargos públicos e eleições, mas certamente ela é conduzida por algumas outras instâncias bem específicas - militares, diplomáticas e estratégicas - que se articulam com as empresariais, cujo campo de ação é necessariamente internacional e nunca tornado público em todos os detalhes. Por isso, a política cotidiana é também intermediada por desenvolvimentistas locais, parceiros empresariais e dinastias fundiárias, em um país que começou com capitanias hereditárias e com terras 'dos outros' cedidas pelo Estado na forma de sesmarias. Além disso, a política de todo dia é também praticada sem recato pelos grupos religiosos, maçônicos e pelas variadas associações profissionais de trabalhadores, de autônomos, patronais, e pelas organizações não governamentais, filantrópicas, assistenciais e outras - muitas das quais se tornam 'acessórias' ou chegam mesmo a ser 'lobistas' dos grupos econômicos e políticos mais poderosos.

A disputa crucial pela informação e a presença megaempresarial em campo - municiada de máquinas possantes, explosivos, combustíveis, emprego de olheiros, informantes, pesquisadores sociais, mobilização de grandes contingentes de trabalhadores - podem ser fatores relevantes para se colocar em xeque o sentido público da ação do Estado e da República Federativa.

Os enredos antes mencionados, localizados e datados - nomeados seus agentes e forças -, ainda que de maneira parcial ou com vieses, confirmam o poderio antiecológico de investidores e seus prepostos locais e comprovam sua disposição antidemocrática. Caso se acompanhassem tais casos mais de perto e por períodos mais longos, anos e décadas, ficaria demonstrada a tendência ao 'bombardeio' de versões e de argumentos - expressão usada pelo sociólogo Bourdieu - necessário para se ocultar tudo o que for possível (Álvarez Benavides, 2005). E também se pode identificar uma verdadeira operação massiva de criação de mentalidades conformadas à ideologia dominante, uma industrialização das mentes, como formulado com brilhantismo há quase meio século pelo ensaísta alemão Hans Magnus Enzensberger (1974).

É obrigatório considerar também, em primeiro plano, além do contexto empresarial e político do Estado, o 'enredo' da região que se modificou radicalmente: o marco de desequilíbrio, de ruptura, ou pelo menos de uma alteração notável foi justamente a chegada da megaobra, mina, usina ou indústria naquele meio de mundo, chocando as comunidades locais. 
Desde então, a história se escreveu por meio dos confrontos e das alianças que resultam da coexistência, no mesmo território, dos projetos de quem já estava e dos projetos dos que vieram depois. Isso pode ser chamado de conflito ambiental, ou de conflito socioambiental, ou de injustiça ambiental. Vários desses casos foram relatados na coletânea organizada por Andréa Zhouri e Klemens Laschefski (2010).

Porém, preferimos caracterizar tais conflitos como uma expressão atualizada da velha luta de classes. Afinal, são antagonismos entre projetos de diferentes grupos de pessoas, com distintos interesses. Trata-se de um embate muito desigual, principalmente, por causa da disposição dos capitalistas em realizar seu próprio projeto, em detrimento de qualquer outro interesse transformar aquele território em um território do capital. Quanto às pessoas, serão expulsas para alhures ou se tornarão vinculadas, assalariadas ou exército de reserva do sistema capitalista que chegou para comandar.

Estaríamos diante de um retrocesso civilizatório? O que de fato significaria essa militarização dos territórios do capital? Tal retrocesso não é raro que ocorra, seja para intervir nos conflitos de classe, seja para tentar assegurar a continuidade da construção e da operação empresarial em plena área conflagrada ou próxima dela. Eis aí outra questão delicada inerente aos grandes projetos aparentemente civis.

Entre os municípios brasileiros decretados pela ditadura militar como de 'segurança nacional', sem poder eleger prefeitos até 1985, estavam aqueles em que funcionavam refinarias de petróleo e usinas hidrelétricas de grande porte. Apesar disso, colonos enganados e prejudicados pela usina de Itaipu, entre Paraná e Paraguai, em construção naquela época, acamparam na avenida de acesso à empresa. Depois de 1985, houve vários outros casos em que os atingidos bloquearam acessos e ocuparam canteiros de obras para exigir e forçar negociações ou para fazer cumprir acordos anteriores. Em Itaparica, nos estados da Bahia e Pernambuco; Manso (MT); Canabrava (GO); Tucuruí (PA); Itá, no Rio Grande do Sul e Santa Catarina; Campos Novos (SC); e ainda na obra do Estreito, divisa Maranhão-Tocantins. Em 2008, discutiu-se no parlamento brasileiro a possibilidade de se transformar tais ações em delinquência, sublevação, ou seja, algo que atentaria contra a segurança nacional: um preâmbulo para se tratar atingidos e ameaçados por barragens, siderúrgicas, mineradoras e outros investimentos de grande porte como 'terroristas'.

As investidas mais recentes vão reduzindo e até anulando conquistas sociais dos grupos étnicos e comunidades tradicionais, tais como: terras 
homologadas de indígenas, comunidades de remanescentes de quilombos, reservas extrativistas de seringueiros, castanheiros, marisqueiros, pescadores. Muitos desses territórios foram previamente transformados em 'blocos' de terrenos a serem leiloados e concedidos pelo Estado a grandes grupos empresariais, em geral estrangeiros, independentemente de consulta prévia aos moradores. A selva amazônica foi 'quadriculada' à revelia pelas agências reguladoras dos negócios petrolíferos no Equador, no Peru e no Brasil (Sevá Filho, 2008b).

Tais investidas caracterizam um verdadeiro impulso combinado de expropriação para a ampliação da infraestrutura e da indústria, e de 'contrarreforma' agrária. A empresa capitalista moderna se confunde com a metrópole colonial, é soberana, como demonstra João Bernardo (2004) em seus estudos sobre o colonialismo português e inglês. $\mathrm{Ou}$, como prognosticou, na sua última obra, o mestre Milton Santos:

O território como um todo é objeto da ação de várias empresas, cada qual preocupada com suas próprias metas, e arrastando, a partir destas metas, o comportamento das demais empresas e instituições. Que resta então da nação, diante dessa nova realidade? Como a nação se exerce diante da verdadeira fragmentação do território, função das formas contemporâneas de ação das empresas hegemônicas? (...) Os fragmentos resultantes desse processo articulamse externamente segundo lógicas duplamente estranhas: por sua sede distante, longínqua quanto ao espaço da ação, e pela sua inconformidade com o sentido preexistente da vida na área em que se instala. Desse modo, produz-se uma verdadeira alienação territorial à qual correspondem outras formas de alienação. (Santos, 2000: 86-87)

Quanto mais crua a dominação política empresarial, mais elaborada a retórica pró-capitalista, na medida em que o crescimento do poderio do grande capital é antidemocrático, mas não pode, em geral, reconhecer isso, e precisa, portanto, que se confundam democracia com capitalismo, liberdade política com liberdade para explorar e para investir. Para a minha geração, que hoje tem 60 anos ou mais e viveu um longo combate à ditadura capitalista sob tutela militar, a fase atual é uma espécie de aprofundamento lógico da mesma luta, pois o poderio político das empresas atualmente é bem maior. A única maneira de não se entregar é pressionar diretamente as empresas, fustigar o capital, mais especificamente, o financeiro. Tornar claro como, quando e quem é diretamente prejudicado, vítima de injustiça, de injúria, de opressão e de violência. E explicar tudo isso, a cada vez, a quantos for possível, enquanto for possível. 


\section{Referências}

ÁLVAREZ BENAVIDES, A. N. La globalización según Bourdieu. Cuadernos de Trabajo Social, 18: 121-135, 2005.

BERNARDO, J. Democracia Totalitária: teoria e prática da empresa soberana. São Paulo: Cortes, 2004.

CONFALONIERI, U. et al. Novas perspectivas para a saúde ambiental: a importância dos ecossistemas naturais. In: SEMINÁRIO NACIONAL DE SAÚDE E AMBIENTE, II, Rio de Janeiro. Anais... Rio de Janeiro: Fundação Oswaldo Cruz, 2002. (Série Eventos Científicos, 4)

DE ANGELIS, M. Marx and primitive accumulation: the continuous character of capitals enclosures. The Commoner, 2: 1-22, 2001. Disponível em: <www.thecommoner.org>. Acesso em: 20 set. 2011.

ENZENSBERGER, H. M. The industrialization of the mind. In: ENZENSBERGER, H. M. \& ROLOFF, M. (Eds.). The Consciousness Industry on Literature, Politics and the Media. New York: The Seabury Press, 1974.

FREITAS, C. M.; PORTO, M. F. S. \& MACHADO, J. M. H. Acidentes Industriais Ampliados: desafios e perspectivas para o controle e prevenção. Rio de Janeiro: Editora Fiocruz, 2000.

HARVEY, D. O Novo Imperialismo. São Paulo: Edições Loyola, 2005.

LEROY, J.P. \& MALERBA, J. IRRSA, Energia e Mineração: ameaças e conflitos para as terras da Amazônia brasileira. Rio de Janeiro: Fase, 2004.

McCULLY, P. Rios Silenciados: ecología y política de las grandes represas. Santa Fé: Proteger Ediciones, 2004.

ROTHMAN, F. (Ed.). Vidas Alagadas: conflitos socioambientais, licenciamento e barragens. Viçosa: Editora UFV, 2008.

SANTOS, M. Por uma Outra Globalização: do pensamento único à consciência universal. Rio de Janeiro: Record, 2000.

SEVÁ FILHO, A. O. Num paraíso da água e da mata, o inferno da pedra fóssil (Piemonte da Serra Geral do sul catarinense), out. 2001. Relatório da $5^{\underline{a}}$ estadia profissional. Disponível em: $<$ www.fem.unicamp.seva/ br>. Acesso em: 21 set. 2011.

SEVÁ FILHO, A. O. (Org.). Tenotã Mõ: alertas sobre as consequências dos projetos de hidrelétricas no rio Xingu. São Paulo: International Rivers Network (IRN), 2005. Disponível em: <www.fem.unicamp.br/ seva>. Acesso em: 21 set. 2001.

SEVÁ FILHO, A. O. Conceitos-chave e precauções no estudo das fontes, dos usos e dos conversores de energia. Campinas: Curso de Engenharia Mecânica/Unicamp, 2006. Disponível em: <www.fem.unicamp.br/ seva>. Acesso em: 20 set. 2011.

SEVÁ FILHO, A. O. Estranhas catedrais: notas sobre o capital hidrelétrico, a natureza e a sociedade. Ciência \& Cultura, 60: 44-50, 2008a. Disponível em: <www.fem.unicamp.br/ seva>. Acesso em: 21 set. 2011.

SEVÁ FILHO, A. O. Selva quadriculada à revelia: povos e poderes em conflito nas Amazônias equatoriana, peruana e brasileira sob o avanço da indústria petrolífera. In: ENCONTRO ANUAL DA ANPOCS (ASSOCIAÇÃO NACIONAL DE PÓS-GRADUAÇÃO E PESQUISA EM CIÊNCIAS SOCIAIS), 32, 2008b, Caxambu. Anais... Caxambu, 2008b. Disponível em: <www. fem.unicamp.br/ seva>. Acesso em: 23 set. 2011.

SEVÁ FILHO, A. O. O cercamento do litoral pelo capital petrolífero: sinais das derrotas dos pescadores e marisqueiros. In: CONGRESO LATINOAMERICANO DE SOCIOLOGIA RURAL, VIII, 2010, Porto de Galinhas. Anais... Porto de Galinhas, 2010. 
SEVÁ FILHO, A. Grandes e polêmicas obras serão chamadas, no Brasil, a 'salvar' o capitalismo global. Entrevista. Correio da Cidadania (edição 769), São Paulo, 11 ago. 2011. Disponível em: $<$ www.correiocidadania.com.br/index.php?option=com_content\&task=view\&id=6161\&Itemi $\mathrm{d}=79>$. Acesso em: 28 set. 2011.

SEVÁ FILHO, O. \& IGLESIAS, M. P. O petróleo e o gás debaixo da terra Pan-Amazônica I, II, III, 2007. (Coluna Papo de Índio). Disponível em: <www.fem.unicamp.br/ seva>. Acesso em: 3 set. 2011.

SEVÁ FILHO, A. O. et al. Renovação e sustentação da produção energética. In: CAVALCANTI, C. (Org.). Desenvolvimento e Natureza: estudos para uma sociedade sustentável. Recife, São Paulo: Fundação Joaquim Nabuco, Cortez, 1995.

SILVA, N. S. Atingidos pela UHE estreito, Estado e corporações transnacionais: etnografia de uma reunião de negociação. In: ENCONTRO BRASILEIRO CIÊNCIAS SOCIAIS E BARRAGENS, III, Belém, 2010. Anais... Belém, 2010.

SÓCIOS DA NATUREZA. Breve histórico da ONGs até 2010. Aranguá, 2011. Disponível em: <www.sociosdanatureza.blogspot.com.br/2011_02_01_archive.html>. Acesso em: 7 abr. 2011.

TREZE USINAS voando. Brasil Energia, Rio de Janeiro, 2011.

TRONCONI, P. A. et al. Pianeta in Prestito: energia, entropia, economia. Preggio: Macroedizione, 1991. Disponível em: <www.fem.unicamp.br/ seva>. Acesso em: 29 set. 2011.

ZHOURI, A. \& LASCHEFSKI, K. (Orgs.). Desenvolvimento e Conflitos Ambientais. Belo Horizonte: Editora UFMG, 2010.

ZHOURI, A.; LASCHEFSKI, K. \& PEREIRA, D. (Orgs.). A Insustentável Leveza da Política Ambiental: desenvolvimento e conflitos socioambientais. Belo Horizonte: Autêntica, 2005. 


\title{
7
}

\section{O Mapa como Espaço de Cidadania: reflexões e continuidades}

\author{
Cristiane Faustino \\ Tania Pacheco \\ Marcelo Firpo Porto \\ Julianna Malerba
}

Tornar o movimento visível quebra o silêncio sobre ele, desafia noções prevalecentes e abre novas possibilidades para todos.

Joan W. Scott

Visibilidade dos Conflitos Ambientais no Mapa: um convite à cidadania transformadora

m entrevista em fevereiro de 2011, uma repórter perguntou à coor-1 denação do Mapa de Conflitos Envolvendo Injustiça Ambiental e Saúde no Brasil (ou Mapa de Conflitos) ${ }^{1}$ quando, afinal, o trabalho terminaria, já que em janeiro completara seu primeiro ano. A resposta foi dupla: "Em termos de utopia, no amanhã; em termos de realidade, quando a concepção de mundo que rege as políticas públicas tiver sido revolucionada. Porque sabemos que, enquanto isso não acontecer, para cada conflito resolvido, dezenas de outros surgirão".

Essa dupla resposta sobre o término ou continuidade do mapa expressa seu significado ético-político de transformação social, que se entende como necessidade estruturante para o enfrentamento efetivo dos conflitos ambientais e das injustiças sociais. Implícita, a premissa se evidencia e

\footnotetext{
${ }^{1}$ Disponível em: <www.conflitoambiental.icict.fiocruz.br>.
} 
se enlaça com a utopia, pois sem a transformação social não é possível revolucionar as concepções das políticas públicas; na verdade, sequer é possível perceber tais concepções ou mesmo a própria política como forma de mediação das relações entre os indivíduos e grupos.

Do ponto de vista metodológico, não só para o mapa, mas também para outras propostas de intervenção que visem a colaborar na revolução das políticas públicas e da política, a vivência e a experiência das lutas contra as injustiças ambientais são fundamentais e precisam ser situadas no debate público/político como problema de toda a sociedade. A persistência dessas injustiças fragiliza as conquistas democráticas e, considerando-se a gravidade dos problemas ambientais e suas relações com as injustiças sociais, põe em xeque os valores éticos e a própria existência material da sociedade, ainda que obrigatoriamente se considerem as diferenças e as desigualdades dos impactos dessa degradação sobre os diferentes grupos sociais.

Porém, como situar com justeza o debate público, quando vivemos tempos de "pós-democracia consensual" (Rancière, 1996) ou, digamos, forjadamente consensual: de apagamento do agir democrático; de privatização dos Estados, submissos ao mercado e à economia internacionalizada; de sujeição dos princípios e práticas democráticas que viabilizam a própria política; de dominação midiática; de supressão dos litígios, judicializados e transformados em meros 'problemas' causados por 'atores arcaicos'?

Sob a 'égide do consenso', não há lugar para os conflitos. Nesse caso, precisa-se camuflá-los, transmutá-los. É necessário revelar apenas os fatos que possam criar situações favoráveis aos setores política, econômica e culturalmente dominantes. Porque aceitar a sua existência significa obrigatoriamente aceitar também a existência do outro, ou melhor, dos 'outros', com suas concepções e propostas de mundo, igualmente portadores dos direitos de cidadania. Também não há lugar para esses direitos - exceto aqueles negociados com os dominadores. E 'direitos negociados' nada mais são do que uma espécie de barganha em torno do mínimo aceitável, fragmentada, à qual os dominados são submetidos para sobreviver, diante dos privilégios de quem os domina.

Contudo, Jacques Rancière (1996: 116) afirma que "aos que deploram a perda da cidadania republicana, a lógica pós-democrática responde com a proclamação da cidadania generalizada". Nessa 'nova cidadania', que pressupõe a exclusão inerente ao modelo de desenvolvimento e o consenso que falsamente tudo resolve, as "empresas-cidadãs" exibem sua energia "produtora e apropriadora", tomando das comunidades seus territórios e 
sua própria razão de ser. Os integrantes de tais comunidades, apresentados como indivíduos considerados incapazes de ser criativos e contratantes, passam a ser representados como sujeitos políticos múltiplos: os 'incontados', como os proletarii romanos, "aquém da democracia, aquém da política" (Rancière, 1996: 122).

A generalização funciona como a perversão da democracia e da política, subjugadas pelo pensamento único e uniforme dos que dominam, assim como pela pretensão destes em portar os valores absolutos, aos quais todos devem se enquadrar. Os que não o fizerem serão as 'minorias', cuja diversidade lhes confere status de menor e de menos importante, diante da grandeza do projeto hegemônico.

Em oposição, o nome do projeto que levou à criação do mapa, tema deste livro, é Mapa dos Conflitos Envolvendo Injustiça Ambiental e Saúde no Brasil, indicando, desde já, a substância estratégica do projeto e da pesquisa: conflitos e não consensos. Conflitos que envolvem litígios pela saúde, pelo direito ao trabalho digno, pelo espaço para produzir, criar e viver, e que a generalização excludente da democracia dos consensos forjados tende a ocultar.

Deles tratam os capítulos deste livro, localizando-os nas suas diferentes origens, responsabilidades, consequências e, acima de tudo, por intermédio da fala dos 'outros': populações atingidas, organizações, movimentos sociais e outros sujeitos que se envolvem em tais conflitos de forma crítica. Por esse ângulo, o mapa convoca a sociedade a tomar ciência e reavaliar sua visão sobre conflitos socioambientais e sobre as lutas sociais e seus sujeitos mobilizadores nele refletidos, que não só reivindicam o direito à existência 'inteira' e 'particular', mas também trazem consigo diferentes formas de entender a realidade e de nela intervir.

Não é por acaso que a palavra 'visibilidade' percorre tanto este livro. A democratização do debate só se faz possível se a visibilidade dessas lutas se constitui mediante o reconhecimento de sua legitimidade política, o respeito aos sujeitos e atores sociais que delas participam, o reconhecimento das causas que os mobilizam e das pautas e direitos que reivindicam. No caso das injustiças e dos conflitos ambientais, essa justa visibilidade é fundamental para se transformar o debate público em processo democrático republicano. Não se constrói processo democrático sem, antes ou junto com ele, democratizarmos a própria cidadania na sua potência criativa e de transformação das injustiças e desigualdades que permeiam o atual estado de organização da vida social. E isso implica poder de decisão sobre a res publica, a 'coisa pública'. 
A cidadania deve extrapolar o exercício de direitos negociados e o acesso a benefícios básicos e se instituir também, ou principalmente, como processo de incidência nas definições de direitos e de cidadania. Daí a sua importância estratégica para a radicalização da democracia. Como afirma Elizabeth Jelin (1994: 119), "o conceito de cidadania refere-se a uma prática conflitiva vinculada ao poder que reflete as lutas em torno de quem poderá dizer o que no processo de definir quais são os problemas comuns e de que forma serão abordados" (grifos do original).

No tocante às injustiças e ao racismo ambiental e a seus impactos sobre a saúde e a vida das comunidades e da sociedade como um todo, o exercício soberano da cidadania se reflete na capacidade e na construção de possibilidades para interferir de diferentes modos no debate público e nas práticas relacionadas ao modelo de desenvolvimento dominante. Mais que isso, tal exercício se reflete na possibilidade de se posicionar diante de tal modelo e de propor outras formas de se pensar e viver em sociedade, abrindo, como diz Joan Scott (1998), "novas possibilidades para todos", até mesmo para aqueles que obrigatoriamente precisam compartilhar/perder poder, sob pena de continuarem comprometendo a democracia e subjugando a cidadania.

No Mapa de Conflitos, a importância do exercício da cidadania se explicita desde sua concepção política e metodológica. Parte de um pressuposto ético de que, no enfrentamento dos conflitos ambientais e de sua incidência sobre a saúde da população, não existem 'incontáveis', como não existe possibilidade da aceitação da 'democracia do consenso'. Diferentes vozes precisam ser ouvidas, ecoadas e processadas nos rumos da política, da participação cidadã e da garantia dos direitos.

Para isso, o mapa apresenta diversas interações possíveis (sujeitos e processos), ainda que se considerem as limitações da vida real: conhecimentos acumulados, habilidades técnicas, capacidade de gerar informações e construir argumentos; organização das populações atingidas; instituições públicas; sociedade civil organizada; militantes políticos; e até mesmo indivíduos não organizados, como veremos adiante.

Ao colaborar com a quebra do silêncio, 'visibilizando' o movimento e considerando diferentes vozes, o mapa apresenta, ora explícitos, ora implícitos, também diferentes reflexos do enfrentamento das injustiças e conflitos ambientais. 


\section{O Mapa e a Democratização do Debate sobre Desenvolvimento a partir dos Conflitos Ambientais}

Analisar a importância do mapa e de sua continuidade à luz do que explicitamos sobre cidadania nos remete à crítica dos processos que limitam o seu exercício. Para isso, tomamos como pressuposto o fato de que as injustiças e os conflitos ambientais são resultados da forma predominante de se pensar e se realizar o desenvolvimento econômico globalizado, que nega, deturpa ou limita a cidadania e os direitos.

Nesse contexto, a importância da continuidade do mapa não se deve somente à atuação cidadã das populações atingidas, dos pesquisadores, militantes sociais, organizações e demais sujeitos políticos envolvidos na sua construção. Mas, sobretudo, à persistência de ideias e práticas de desenvolvimento econômico que, com caráter 'moderno conservador', orientam a iniciativa privada nacional e internacional. Na relação histórica com o Estado, a iniciativa privada se situa em lugares de privilégios, na medida em que tem maior acesso às instituições públicas e é a seu favor que se destina a maior parte dos esforços institucionais. Além disso, também na relação com a sociedade civil, a iniciativa privada goza de maior e mais imediata incidência política, econômica e cultural, tanto sobre as instituições como sobre o cotidiano.

A modernidade conservadora desse modelo de desenvolvimento, que extrapola os limites da economia e 'invade' praticamente toda a vida social, baseia-se no 'aperfeiçoamento' ideológico das tecnologias de produção; na privatização da ciência e do conhecimento; na dinamização, complexificação e intersecção de amplas cadeias produtivas dos mais variados mercados; na diversificação das possibilidades de exploração da natureza e das relações sociais; na privatização e 'detonação' dos bens comuns; na privatização das instituições e da vida pública; e na 'sacralização' da produção, acumulação e concentração de mercadorias como única forma viável de mediação para a existência social na terra.

Ideológica e simbolicamente, tal modelo também se apresenta e se justifica no pensamento, no discurso e na vida real como fatalidade. O progresso, nesse caso, passa a ser a uniformização da vida e do cotidiano, com base nas premissas e estéticas do capitalismo contemporâneo, na sua pretensa inevitabilidade e incontestável capacidade de se reproduzir, mesmo nos diferentes e mais longínquos territórios, se assim lhe for conveniente.

Para os que representam e/ou defendem esse modelo, o território onde está ausente sua força motora é sinônimo de atraso e mediocridade das 
populações e modos de vida locais. Essa é uma prova inelutável do poder arrogante e narcisista que marca a expansão das atividades produtivas de escala e de grandes impactos sociais e ambientais. E, se é assim que os conflitos ambientais são gerados pela iniciativa privada e seus projetos, é também nos termos dessa lógica - defendida amplamente pelos meios de comunicação que eles são deslegitimados ou ocultados.

Ademais, se de alguma forma os conflitos conseguem se tornar visíveis e 'judicializáveis', isso se dará também de forma desigual, pois será por influência desses lugares de privilégio dos setores dominantes, protegidos sob a 'égide do consenso' e da 'cidadania generalizada' excludente, que eles são analisados, julgados e decididos. Suas propostas de soluções estarão marcadas, a priori, pelo desfavorecimento dos grupos atingidos ou dos questionadores da lógica predominante nos projetos e políticas de desenvolvimento.

Se esse contexto não torna impossível (dada a força das lutas sociais), dificulta gravemente a efetivação da cidadania, uma vez que, de um lado, esse modelo estabelece correlações de forças desiguais e desfavoráveis para as vozes que ponderam, questionam, não concordam com as premissas desses projetos e políticas e/ou são duramente atingidas por elas em sua vida cotidiana; de outro, opera com o próprio boicote à cidadania, e é, portanto, marcado pelo autoritarismo. Pior do que isso, camufla o fato de que tais políticas e projetos não poderiam sequer existir, a menos que tivessem como uma de suas partes constituintes as injustiças e a submissão dos direitos à sua lógica totalitária.

Contudo, os conflitos ambientais se instalam também porque esse modo de se pensar e se fazer o desenvolvimento, embora predominante, não é o único e, a despeito de seus discursos autoelogiosos, não se mostra razoável para o bem comum. Isso explica por que tantos e diferentes grupos sociais resistem e fazem contrapontos Brasil afora e, com base em premissas cidadãs, desafiam 'noções prevalecentes' de diferentes formas: anunciando a si mesmos; explicitando as injustiças e desigualdades; denunciando as diferentes violações de que são vítimas e/ou testemunham; reivindicando direitos; valorizando, criando e recriando contrapropostas; construindo diferentes mecanismos de visibilidade pública e debate com a sociedade.

É nesse movimento que se tornam possíveis e/ou se apresentam as conquistas, ainda que em grande parte localizadas e frágeis diante da força operacional e política do sistema capitalista e das inconsistências de tais conquistas na vida cotidiana. Inconsistências que se devem às fragilidades 
dos órgãos públicos que deveriam garanti-las, que são resultantes do elitismo, conservadorismo e autoritarismo da cultura política e do poder econômico dominante.

Sob esses aspectos e no diálogo com a diversidade, o mapa se revela como um espaço de cidadania para a construção da justiça ambiental e o combate ao racismo ambiental. Inicialmente, porque colabora para a visibilização de diferentes sujeitos, concepções, realidades e situações que emergem a partir dos conflitos ambientais, ao mesmo tempo operantes e resultantes do modelo dominante. Ao fazê-lo, 'desoculta' e redireciona o olhar sobre esses grupos sociais, ao contrário do que normalmente se observa nos grandes meios de comunicação.

Na perspectiva dessa dominação midiática, a diversidade é um entrave, e seus representantes são apelativamente desqualificados em sua condição de sujeitos, tratados como 'falsos índios'; 'falsos quilombolas; 'comunidades folclóricas', 'rudimentares' e 'insalubres'; falsos 'sem-terra' da pujança e da contravenção; ou 'militantes desocupados'. Essa dominação midiática é hoje, inegavelmente, uma das maiores desvirtuadoras da noção de direitos. Os direitos e a cidadania são reconhecidos em uma concepção individualista e consumista, que aparta o indivíduo dos seus sentidos/tempos e contextos coletivos e qualifica os cidadãos como transeuntes alucinados de um enorme shopping center, onde tudo se vende e tudo se compra, do pão ao afeto e à felicidade.

O mapa organiza e reinventa a democratização das informações, colocando em cena pública as contradições e a realidade vivida e pensada ao considerar a ótica de outros sujeitos e as outras formas de conceber e analisar a realidade, diferente daquelas que estão mais costumeiramente acessíveis à sociedade. Isso é importante porque a dominação midiática não acontece por acaso. O conteúdo dos meios de informação convencionais é marcado pela predominância do poder político, econômico e cultural da iniciativa privada, lugar no qual se originam os agentes que investem nos territórios e provocam os danos e os conflitos ambientais - mapeados ou não.

Tal predominância gera uma situação de injustiças no acesso às instituições e aos processos decisórios, desfavorecendo e, muitas vezes, criminalizando as populações e grupos historicamente excluídos. Outras vezes, cria situações em que representantes dos interesses privados 'protagonizam' os espaços de julgamento, decisão ou mediação dos conflitos ambientais em detrimento dos atingidos - aqueles que devem sair do 'meio do caminho', adequar-se, submeter-se ou desaparecer. 
O mapa explicita e problematiza, em espaço público e de forma relativamente acessível, o caráter agressivo e as violações provocadas pelos projetos econômicos de grandes impactos sociais sobre populações e territórios, bem como evidencia os responsáveis pelos danos. E, ao fazê-lo, traz à tona os sujeitos que as acobertam ou não as impedem. Esse impedimento, na maioria dos casos, poderia ser feito com o cumprimento das leis e poderia e deveria ser entendido como monitoramento e cobrança legítimos do Estado, dos governos e da justiça, como um exercício de cidadania.

Constituído com base na realidade vivida e nas experiências de sujeitos e atores sociais invisibilizados ou negados, subjugados pela operacionalização do modelo dominante, o mapa também colabora para a conjugação de informações e construção de sinergias. Subsidia a elaboração democrática de conhecimentos sobre a realidade do desenvolvimento brasileiro, incluindo e problematizando informações importantes, porém ocultadas na narrativa autopromocional e acrítica do 'progresso' e do desenvolvimento.

Além disso, o mapa faz uma justa mediação entre os grupos impactados pelos projetos político-econômicos e a sociedade, ao lhes garantir, com apoio de profissionais e militantes, o usufruto efetivo dos recursos da tecnologia da informação, como a Internet e o uso de GPS, por exemplo. Assim, colabora também para experiências recentes de construções coletivas de politização e democratização de espaços midiáticos de interação social consolidados na atualidade.

Finalmente, o mapa fornece ainda dados importantes sobre as conquistas democráticas e seus processos técnicos, jurídicos e políticos, além de servir de 'convite' a articulações entre grupos envolvidos em conflitos semelhantes, seja no campo ou nas cidades.

\section{Exercitando a Cidadania na Construção do Mapa: um breve histórico}

Para que a luta política e a construção da democracia e da cidadania aconteçam não basta se construir, com base na utopia, mais um instrumento a seu serviço. É fundamental que aos objetivos, às metas e às esperanças correspondam respostas reais em termos de ação, apropriação, 'tomada de posse'. Trataremos nesta seção da necessária tomada de posse do que o Mapa de Conflitos oferece, em termos reais e potenciais, tanto por parte das pessoas envolvidas nos conflitos como pelas que têm sido suas parceiras nas lutas.

No tocante às comunidades atingidas e à sociedade civil, a participação se iniciou paralelamente ao trabalho dos pesquisadores e antes mesmo da 
definição dos casos que seriam priorizados nos diferentes estados. Esse pequeno histórico merece ser socializado, até mesmo pela informação que nos dá sobre a vontade e a disponibilidade das pessoas para atuar politicamente, além dos partidos e, em grande parte dos casos, além das próprias organizações da sociedade civil.

\section{As primeiras denúncias e o Fale Conosco}

Em outubro de 2008, foi criado o FormSUS (Anexo), um formulário semelhante ao que seria usado pelos pesquisadores, mas ao qual qualquer pessoa poderia ter acesso para fazer suas denúncias. O FormSUS é um programa do Datasus desenvolvido para a coleta de dados especificamente ligados à área da saúde. É possível adaptá-lo de acordo com as necessidades da pesquisa a ser feita, após um rápido curso, feito nas próprias dependências do setor do Ministério da Saúde que o desenvolve e mantém, com a devida autorização do ministério. $\mathrm{O}$ uso desse recurso está mais detalhadamente explicado no capítulo 1, que trata da parte metodológica do mapa.

O nome do formulário era exatamente "Denúncias envolvendo injustiça ambiental e saúde" e foi divulgado em uma pequena nota, enviada às listas de endereços eletrônicos da Rede Brasileira de Justiça Ambiental (RBJA) e dos Grupos de Trabalho (GTs) a ela ligados e a outras listas parceiras, anunciando a novidade e pedindo colaborações, quer em denúncias, quer em divulgação da possibilidade de fazê-las. Além disso, algumas pessoas ligadas ao projeto - ou que o apoiavam como militantes - passaram a incluir ao final dos e-mails enviados a seguinte pergunta: "Denúncias sobre injustiça ambiental e saúde no Brasil?". E, para complementá-la, na linha a seguir constava o endereço eletrônico para o qual as respostas poderiam ser encaminhadas.

Utilizando-se essa estratégia e o FormSUS, até o final de 2009 foram recebidos 133 formulários, com as mais diversas denúncias. O Gráfico 1 apresenta a quantidade de casos por estado.

De todos os estados veio alguma contribuição, mesmo que, de sete deles, tenha vindo apenas uma denúncia. A presença expressiva de outros, por sua vez (Rio de Janeiro, com 49; São Paulo, com 23; e Minas Gerais, com 13), pode ser entendida menos como resultante de um maior 'interesse' e mais como uma maior capacidade de atingi-los e mobilizá-los, uma vez que, como já foi dito, a divulgação estava focada nos integrantes das listas que recebiam a informação e o convite para participação ativa.

Dessas 133 denúncias, apenas 34 foram encaminhadas por integrantes da RBJA e do GT Combate ao Racismo Ambiental, do GT Químicos, e, mais 
tarde, também do recém-instituído GT Articulação Mineração e Siderurgia. Esse fato é facilmente explicável: a RBJA já era parceira 'nata' na implementação do projeto, uma vez que as listas de seus GTs e a dela própria seriam a base de informações. E continuariam a sê-lo durante todo o projeto, o que era de conhecimento de seus integrantes. Importa, pois, destacar, nessa contagem, o exercício de cidadania feito por pessoas e entidades que não tinham qualquer relação com a rede; pessoas que registraram as informações constantes em 99 formulários com base em vivências diferenciadas, mas levadas por suas indignações, coletivas ou individuais. Em muitos casos, tratava-se de denúncias provenientes de pessoas físicas; em outros, das mais diversas organizações, de associações de moradores à maçonaria.

Gráfico 1 - Número de conflitos por estado

\begin{tabular}{|r|r|r|r|}
\hline & & Qdd & Qtd. $\%$ \\
\hline Estado & 1 & $0,75 \%$ \\
\hline Alagoas & 1 & $0,75 \%$ \\
\hline Bmazonas & 8 & $6,02 \%$ \\
\hline Ceará & 1 & $0,75 \%$ \\
\hline Distrito Federal & 1 & $0,75 \%$ \\
\hline Espírito Santo & 3 & $2,26 \%$ \\
\hline Goiás & 2 & $1,50 \%$ \\
\hline Maranhão & 6 & $4,51 \%$ \\
\hline Mato Grosso & 6 & $4,51 \%$ \\
\hline MatoGrossodoSul & & 2 & $1,50 \%$ \\
\hline Minas Gerais & & 13 & $9,77 \%$ \\
\hline Pará & 3 & $2,26 \%$ \\
\hline Paraná & & 4 & $3,01 \%$ \\
\hline Pernambuco & 1 & $0,75 \%$ \\
\hline Rio de Janeiro & 49 & $36,84 \%$ \\
\hline Rio Grande do Sul & Fichas preenchidas & 133 & $100,0 \%$ \\
\hline Roraima & Não responderam & 0 & $0,00 \%$ \\
\hline Santa Catarina & & 2 & $1,50 \%$ \\
\hline São Paulo & & 5 & $3,76 \%$ \\
\hline Tocantins & & 23 & $17,29 \%$ \\
\hline & & 1 & $0,75 \%$ \\
\hline & & & 1 \\
\hline
\end{tabular}

Fonte: Elaborado pelos autores com base nos dados do Mapa de Conflitos Envolvendo Injustiça Ambiental e Saúde no Brasil.

À época, a única denúncia sobre o Amazonas, relativa às dificuldades enfrentadas pelo povo indígena Mura em Autazes, veio de uma pesquisadora da Universidade de Santa Catarina. Outra, sobre os problemas enfrentados por pescadores e marisqueiras em Maragogipe (BA), partiu de uma brasileira 
da Universidade de Plymouth, Inglaterra. Esses dois exemplos nos levam a pensar que, se o uso da Internet e o acesso às informações dela advindas são ainda muito difíceis para as comunidades locais, nada impede que outros, que gozam de situações mais privilegiadas, possam e devam utilizar esse mecanismo, e, em um comprometimento ético, denunciar injustiças das quais têm conhecimento. Isso, porém, não diminui a importância da participação direta das populações atingidas na elaboração e usufruto de tecnologias e mecanismos de comunicação virtual. Tal usufruto deve ser tratado também como fator a ser democratizado e é, pois, um desafio a ser enfrentado permanentemente.

Funcionários de órgãos públicos também estão presentes na listagem, assim como empregados das próprias empresas causadoras dos conflitos. Em alguns desses casos, os itens que solicitavam preenchimento de nome, e-mail, telefone e instituição, apresentaram respostas como "não posso dizer" ou "não quero me identificar", por exemplo. Mas a leitura dos formulários deixa clara a importância da contribuição e o motivo do anonimato.

Para demonstrarmos a seriedade com que essas denúncias foram feitas, o cuidado com que as informações foram repassadas e a amplitude das populações atingidas, vale examinar alguns gráficos sobre o preenchimento dessas 133 fichas. O Gráfico 2 trata das populações e grupos atingidos, e as respostas não estão limitadas ao urbano, revelando casos bastante diferenciados e, em grande parte, rurais.

Os impactos e riscos ambientais apresentados mostram a preocupação dos denunciantes com os danos à saúde que são gerados nesses conflitos e a sua capacidade de reconhecê-los, como evidenciam os Gráficos 3 e 4.

O Gráfico 5, o último (mas muitos outros poderiam ser aqui apresentados), evidencia a identificação, por parte dos participantes, dos responsáveis atividades ou instituições - pelos conflitos. Os dados corroboram totalmente a síntese do mapa apresentada no capítulo 1: o papel do Estado e o não cumprimento das leis, principais causadores dos conflitos.

O esforço em se precisar os dados deixa explícita a importância atribuída às denúncias por parte das pessoas que, na condição de cidadãs, as fizeram. $\mathrm{Na}$ época, elas tinham apenas o convite para preencher o formulário. Em alguns casos, sequer sabiam que o mapa estava sendo construído. E, mesmo que o soubessem, nada comprovava que, de fato, seria concretizado e disponibilizado na Internet. Mesmo assim, consideraram válido divulgar os problemas que marcavam os conflitos socioambientais dos quais tinham conhecimento, assim como os grupos que eram por eles atingidos. 
Gráfico 2 - Populações envolvidas nos conflitos

\begin{tabular}{|c|c|c|c|}
\hline $\begin{array}{l}\text { Qualotipodepopulação } \\
\text { atingida? }\end{array}$ & & Qtd & Qtd. \% \\
\hline Agricultoresfamiliares & 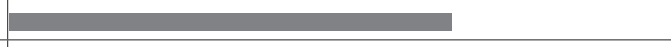 & 54 & $40,60 \%$ \\
\hline Caiçaras & +2 & 24 & $18,05 \%$ \\
\hline Marisqueiras & +2 & 14 & $10,53 \%$ \\
\hline $\begin{array}{l}\text { Moradoresdeaterrose/ou } \\
\text { terrenoscontaminados }\end{array}$ & \begin{tabular}{|c|c|} 
\\
\end{tabular} & 22 & $16,54 \%$ \\
\hline $\begin{array}{r}\text { Moradoresdoentorno } \\
\text { de lixões }\end{array}$ & & 22 & $16,54 \%$ \\
\hline $\begin{array}{r}\text { Moradoresemencostas } \\
\text { e favelas }\end{array}$ & & 27 & $20,30 \%$ \\
\hline Operários & 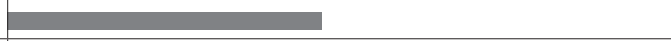 & 38 & $28,57 \%$ \\
\hline Pescadoresartesanais & 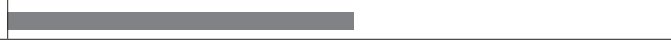 & 42 & $31,58 \%$ \\
\hline Povos indígenas & 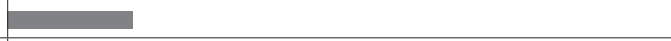 & 15 & $11,28 \%$ \\
\hline Quebradeirasdecoco & 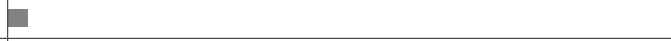 & 2 & $1,50 \%$ \\
\hline Quilombolas & 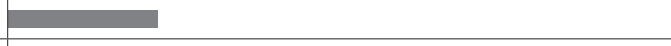 & 18 & $13,58 \%$ \\
\hline Ribeirinhos & 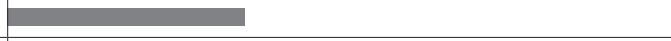 & 29 & $21,80 \%$ \\
\hline Seringueiros & 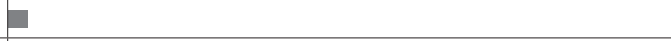 & 2 & $1,50 \%$ \\
\hline \multirow[t]{3}{*}{ Outros } & 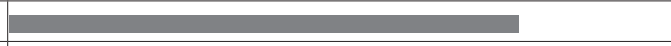 & 62 & $46,62 \%$ \\
\hline & Fichas preenchidas & 133 & $100,00 \%$ \\
\hline & Não responderam & 0 & $0,00 \%$ \\
\hline
\end{tabular}

Obs.: Há muitas comunidades que se autoidentificam como pertencentes a mais de um grupo, como, por exemplo, quilombolas que atuam como vazanteiros; agricultores familiares sem-terra; ribeirinhos que sobrevivem também como pescadores artesanais e extrativistas. Da mesma forma, muitas vezes há mais de um dano ambiental, mais de um agravo à saúde e mais de um responsável pelo conflito. Essa sobreposição faz com que os percentuais, se somados, cheguem a mais de $100 \%$.

Fonte: Elaborado pelos autores com base nos dados do Mapa de Conflitos Envolvendo Injustiça Ambiental e Saúde no Brasil.

Todas as informações advindas dessa primeira fase de coleta foram retrabalhadas pelos pesquisadores. Algumas eram imediatamente incluídas por se tratarem de conflitos já identificados como prioritários para a versão inicial do mapa, outras foram separadas para a segunda fase, a ser iniciada logo após seu lançamento na Internet. A 'estreia' do Mapa de Conflitos na Internet, em março de 2010, marcou um novo momento e determinou novas formas de participação, mediante denúncias e manifestações públicas: as reclamações indignadas e o uso do Fale Conosco.

Embora houvesse a preocupação de se explicar de variadas formas (notícias sobre o lançamento, entrevistas, e no próprio mapa, na seção "Metodologia") os motivos que determinaram a escolha daqueles 297 casos iniciais, chegaram reclamações indignadas de organizações e pessoas dos mais diversos estados. Em todas, queixavam-se da ausência de conflitos que consideravam necessário estarem explicitados já nessa primeira versão. 
Gráfico 3 - Principais impactos e riscos ambientais

\begin{tabular}{|c|c|c|c|}
\hline $\begin{array}{l}\text { Quaisosimpactoserisco } \\
\text { ambientais? }\end{array}$ & & Qdd & Qtd. \% \\
\hline $\begin{array}{l}\text { Alteração no ciclo } \\
\text { reprodutivo da fauna }\end{array}$ & & 59 & $44,36 \%$ \\
\hline $\begin{array}{l}\text { Alteração no regime } \\
\text { tradicional de uso e } \\
\text { ocupação do território }\end{array}$ & & 57 & $42,86 \%$ \\
\hline $\begin{array}{l}\text { Assoreamento de } \\
\text { recurso hídrico }\end{array}$ & & 57 & $42,86 \%$ \\
\hline $\begin{array}{l}\text { Desmatamento } \\
\text { e/ou queimada }\end{array}$ & & 50 & $37,59 \%$ \\
\hline Erosão do solo & 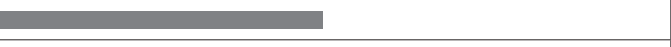 & 50 & $37,59 \%$ \\
\hline $\begin{array}{r}\text { Falta/irregularidadena } \\
\text { autorização ou } \\
\text { licenciamentoambiental }\end{array}$ & & 66 & $49,62 \%$ \\
\hline $\begin{array}{r}\text { Falta/irregularidadena } \\
\text { demarcação de } \\
\text { território tradicional }\end{array}$ & & 29 & $21,80 \%$ \\
\hline $\begin{array}{r}\text { Invasão/dano a área } \\
\text { protegida ou unidade } \\
\text { de conservação }\end{array}$ & & 50 & $37,59 \%$ \\
\hline Mudanças climáticas & 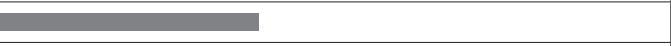 & 40 & $30,08 \%$ \\
\hline Pescaoucaçapredatória & 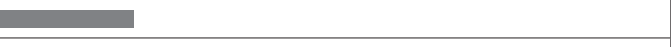 & 21 & $15,79 \%$ \\
\hline Poluição atmosférica & 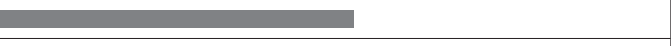 & 55 & $41,35 \%$ \\
\hline Poluiçãoderecursohídrico & & 91 & $68,42 \%$ \\
\hline Poluição do solo & 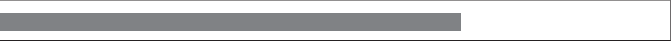 & 71 & $53,38 \%$ \\
\hline Poluição sonora & 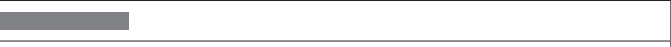 & 20 & $15,04 \%$ \\
\hline \multirow[t]{3}{*}{ Outros } & 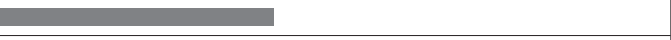 & 42 & $31,58 \%$ \\
\hline & Fichas preenchidas & 133 & $100,00 \%$ \\
\hline & Não responderam & 0 & $0,00 \%$ \\
\hline
\end{tabular}

Obs.: Há muitas comunidades que se autoidentificam como pertencentes a mais de um grupo, como, por exemplo, quilombolas que atuam como vazanteiros; agricultores familiares sem-terra; ribeirinhos que sobrevivem também como pescadores artesanais e extrativistas. Da mesma forma, muitas vezes há mais de um dano ambiental, mais de um agravo à saúde e mais de um responsável pelo conflito. Essa sobreposição faz com que os percentuais, se somados, cheguem a mais de $100 \%$.

Fonte: Elaborado pelos autores com base nos dados do Mapa de Conflitos Envolvendo Injustiça Ambiental e Saúde no Brasil.

O mais importante instrumento de participação, na segunda fase, foi (e continua a ser) o espaço Fale Conosco, inserido como uma página especial no site do mapa. Seu início foi pouco expressivo, mas uma entrevista concedida por Marcelo Firpo Porto ao programa Jornal Nacional, da Rede Globo de Televisão, mostrou, de um lado, a força desse meio de comunicação; de outro, os prejuízos que uma reportagem editada de forma apressada pode trazer: em menos de 24 horas (e começando com o noticiário ainda no ar), mais de duzentas mensagens foram enviadas por meio do site. 
Gráfico 4 - Principais riscos, agravos e danos à saúde

\begin{tabular}{|r|r|r|r|}
\hline $\begin{array}{r}\text { Quaisosproblemasouriscosà } \\
\text { saúdeenvolvidosnoconflito? }\end{array}$ & Qtd & Qtd. \% \\
\hline Acidentes & Desnutrição & 48 & $36,09 \%$ \\
\hline $\begin{array}{r}\text { Doençasnãotransmissíveis } \\
\text { ou crônicas }\end{array}$ & 33 & $24,81 \%$ \\
\hline Doençastransmissíveis & 70 & $52,63 \%$ \\
\hline Faltadeatendimentomédico & & 44 & $33,08 \%$ \\
\hline Suicídio & & 40 & $30,08 \%$ \\
\hline Pioranaqualidadedevida & & 10 & $7,52 \%$ \\
\hline Violência - ameaça & & 113 & $84,96 \%$ \\
\hline Violência-assassinato & 41 & $30,83 \%$ \\
\hline Violência-coaçãofísica & Fichas preenchidas & 133 & $100,00 \%$ \\
\hline Violência-lesãocorporal & Não responderam & 0 & $0,00 \%$ \\
\hline Outros & & 27 & $20,30 \%$ \\
\hline & & 15 & $11,28 \%$ \\
\hline
\end{tabular}

Obs.: Há muitas comunidades que se autoidentificam como pertencentes a mais de um grupo, como, por exemplo, quilombolas que atuam como vazanteiros; agricultores familiares sem-terra; ribeirinhos que sobrevivem também como pescadores artesanais e extrativistas. Da mesma forma, muitas vezes há mais de um dano ambiental, mais de um agravo à saúde e mais de um responsável pelo conflito. Essa sobreposição faz com que os percentuais, se somados, cheguem a mais de $100 \%$.

Fonte: Elaborado pelos autores com base nos dados do Mapa de Conflitos Envolvendo Injustiça Ambiental e Saúde no Brasil.

A entrevista chamou a atenção de um grande público para o mapa, colaborando para a sua divulgação. Entretanto, a notícia acabou gerando a muitos telespectadores a ideia de que ele era uma espécie de 'balcão de reclamações'. Assim, na maioria dos casos, as denúncias eram pessoais e tinham pouca relação com as definições de conflitos ambientais para fins de montagem do mapa. Referiam-se a vizinhos que jogavam lixo no meio da rua, alagamentos, falta de postos de saúde no bairro e problemas assemelhados. Na verdade, poucas de fato correspondiam aos objetivos do mapeamento.

Porém, no balanço da participação no Fale Conosco até 31 de dezembro de 2010, o número total de denúncias foi bastante significativo. Sem contabilizar comentários elogiosos, indagações sobre formas de colaboração e ofertas de apoios políticos, em 11 meses foram recebidas 231 respostas, entre novas denúncias e complementações de casos já postados. Nas duas situações, essas informações já foram ou têm sido trabalhadas pelos pesquisadores.

Esse é um número bastante expressivo, considerando-se a realidade do país e o fato de que muitas informações provêm de pessoas com pouco domínio da escrita formal. A falta dessa habilidade, que pode ser um entrave, 
aliada à necessidade de se conectar, buscar o endereço e a página específica e, finalmente, preencher os campos para formalizar a denúncia, reflete não só os esforços, mas também as dificuldades de participação que recaem especialmente sobre a maioria das populações atingidas.

Outra forma de participação na construção do mapa tem relação direta com o material já disponibilizado na Internet. E, dessa maneira, entram de forma mais concreta as contribuições de entidades e organizações diversas, inclusive do meio acadêmico, com críticas, complementação e atualização dos conflitos.

Gráfico 5 - Principais responsáveis pelos conflitos

\begin{tabular}{|r|r|r|l|}
\hline $\begin{array}{r}\text { Quais os processos } \\
\text { produtivos? }\end{array}$ & Qtd & Qtd. \% \\
\hline $\begin{array}{r}\text { Atividades pesqueiras } \\
\text { e carcinicultura }\end{array}$ & 30 & $22,56 \%$ \\
\hline Madeireiras & & 6 & $4,51 \%$ \\
\hline $\begin{array}{r}\text { Monocultura } \\
\text { Indústria química e } \\
\text { do petróleo }\end{array}$ & 15 & $11,28 \%$ \\
\hline $\begin{array}{r}\text { Mineração, garimpos } \\
\text { e siderurgia }\end{array}$ & 18 & $13,53 \%$ \\
\hline $\begin{array}{r}\text { Barragensehidrelétricas } \\
\text { Hidroviasrodoviasgasodutos }\end{array}$ & 23 & $17,29 \%$ \\
\hline Energiaeradiaçõesnudleares & & 13 & $9,77 \%$ \\
\hline Termoelétricas & & 10 & $7,52 \%$ \\
\hline $\begin{array}{r}\text { Políticaspúblicaselegislação } \\
\text { ambiental }\end{array}$ & 4 & $3,01 \%$ \\
\hline $\begin{array}{r}\text { Implantação de áreas } \\
\text { protegidas }\end{array}$ & 6 & $4,51 \%$ \\
\hline $\begin{array}{r}\text { Atuação de entidades } \\
\text { governamentais }\end{array}$ & 63 & $47,37 \%$ \\
\hline $\begin{array}{r}\text { AruaçãodoJudiciárioe/ou } \\
\text { do Ministério Público }\end{array}$ & Fichas preenchidas & 133 & $100,00 \%$ \\
\hline Outros & Não responderam & 0 & $0,00 \%$ \\
\hline & 32 & $24,06 \%$ \\
\hline & 58 & $43,61 \%$ \\
\hline
\end{tabular}

Obs.: Há muitas comunidades que se autoidentificam como pertencentes a mais de um grupo, como, por exemplo, quilombolas que atuam como vazanteiros; agricultores familiares sem-terra; ribeirinhos que sobrevivem também como pescadores artesanais e extrativistas. Da mesma forma, muitas vezes há mais de um dano ambiental, mais de um agravo à saúde e mais de um responsável pelo conflito. Essa sobreposição faz com que os percentuais, se somados, cheguem a mais de $100 \%$.

Fonte: Elaborado pelos autores com base nos dados do Mapa de Conflitos Envolvendo Injustiça Ambiental e Saúde no Brasil. 


\section{Os sujeitos e atores e a sua participação}

O histórico da pesquisa de campo para o mapa revela que, mesmo tendo como princípio político e base metodológica a participação direta dos atingidos nos conflitos ambientais, sua construção envolve diferentes sujeitos que fazem lutas sociais e se articulam no enfrentamento desses conflitos: organizações de apoio aos atingidos; movimentos e militantes sociais; pesquisadores e estudiosos. Mas também evidencia a possibilidade de se atrair alguns atores importantes, como trabalhadores vinculados às empresas implicadas nos conflitos e organizações religiosas (como veremos mais adiante).

Isso revela também que o mapa, como instrumento para subsidiar o debate sobre os conflitos ambientais e seus impactos sobre a saúde e as políticas públicas nesses campos, vai ao encontro do exercício preexistente de cidadania nas lutas sociais. E, ainda que não tenha como dar conta de tudo (e não é, nem poderia ser esse seu objetivo), tem potencial para revelar demandas de indivíduos com avidez de participação. $\mathrm{O}$ voluntarismo, mesmo com suas limitações, tem sua importância, pois demonstra que, além dos grupos envolvidos em lutas específicas e dos militantes em geral, pessoas comuns, não organizadas, também pensam e se posicionam diante das injustiças ambientais.

Para se considerar os diferentes sujeitos envolvidos na construção inicial do mapa, é importante situar essas diversas formas de participação direta e difusa na sua elaboração também como encadeamento das escolhas políticas e metodológicas preliminares dos sujeitos que o conceberam. No Brasil, o mapa se insere paralelamente e como instrumento na construção do debate sobre as degradações socioambientais à luz das perspectivas desses sujeitos.

Das articulações com os movimentos sociais dos Estados Unidos, passando pela criação e atuação da própria RBJA, pela construção do Mapa dos Conflitos Ambientais no Rio de Janeiro, pelo Mapa dos Conflitos Causados por Racismo Ambiental no Brasil, surgiram sujeitos de diferentes campos que influenciaram direta ou indiretamente a construção do mapa, especialmente das organizações não governamentais (ONGs) populares democráticas, dos movimentos sociais, das defensorias e dos ministérios públicos, da academia e de instituições de ensino e pesquisa.

Em meio ao encontro de diferentes áreas de intervenção - que também é animador e animado pelo mapa - estimulam-se a articulação e a interconexão de temas, leituras e informações que fortalecem a construção do conceito de justiça ambiental, quer como aporte para a crítica às injustiças e ao racismo ambiental quer para a ação política militante. 
A cidadania exercida para promover esse encontro se desencadeia socializando e reconstruindo o debate, contando de forma intencional com a participação dos que são mais direta e imediatamente atingidos, ainda que isso seja perpassado por diferentes desafios de ordem estruturante.

Estão presentes também o Estado e a academia, instâncias que cumprem papel central nas responsabilidades e exercícios de autoridades públicas, pois gozam de poderes e formalidades institucionais legitimadas. E, no caso específico da academia, desfruta de seu reconhecimento 'de direito' - embora nem sempre 'de fato' - como lócus do conhecimento.

\section{O papel, a importância e os desafios da presença do Estado na construção do mapa}

A iniciativa de se discutir de forma articulada dois temas de alta relevânciaconflitos ambientais e saúde - como questões de ordem pública e se destinar esforços institucionais para isso representa um importante avanço no debate. Mais que isso, explicita um campo de possibilidades, ainda que localizadas e com pouca envergadura institucional, para a intervenção política no Estado e no governo que, por sua vez, precisam urgentemente ser reestabelecidos em suas funções no que se refere à promoção dos direitos e da cidadania.

As potencialidades e limites do papel do Estado diante dos conflitos ambientais registrados no mapa começaram a ser observados (e merecem ser aqui considerados) já pelas reações que se seguiram ao seu lançamento. Como era de se esperar - expressando a natureza dialética no processo de visibilização pública e a busca por hegemonias frente aos conflitos-, além dos elogios, vários protestos foram levados diretamente à direção da Fundação Oswaldo Cruz (Fiocruz) por parte de empresas e setores econômicos citados, principalmente envolvendo o agronegócio e indústrias ligadas aos setores nuclear e petrolífero, inclusive empresas estatais. Os protestos chegavam a solicitar a retirada ou a mudança de informações do mapa que "não representariam posições científicas robustas" ou estariam "em contradição com posições de grupos técnico-científicos" (em pelo menos um caso, um grupo da própria Fiocruz) que sustentavam a inexistência de problemas socioambientais e de saúde decorrentes do empreendimento em questão.

As argumentações da coordenação do mapa para manter o conteúdo original das informações se basearam na própria concepção e na metodologia do projeto: o objetivo sempre foi apresentar os conflitos com ênfase nas demandas e experiências das populações atingidas, e não em uma visão e em uma prática científica supostamente neutras e desprovidas de valor. 
Contudo, durante a construção do mapa, não deixamos de avaliar com rigor a consistência das denúncias e demandas. Foi constatada em cada caso, principalmente nos mais polêmicos, a robustez dos argumentos levantados pelos pesquisadores do projeto na análise dos relatórios e documentos produzidos por instituições parceiras ou na análise das ações de ministérios públicos, assim como dos 'pareceres' dos validadores (termo explicado no capítulo 1) de cada estado.

Outra consideração importante diz respeito à dimensão política das informações e incertezas em jogo: muitos casos evidenciam a falta de informações e estudos que investigassem mais precisamente os possíveis problemas socioambientais e de saúde que preocupam as populações nos territórios. Ainda no âmbito político, evidencia-se também o posicionamento de instituições e grupos de especialistas que negligenciam a complexidade do problema e a necessidade de uma abordagem precaucionária diante das incertezas em jogo. Ou seja, muitas vezes a falta de evidências robustas que associassem, por exemplo, problemas de saúde aos empreendimentos denunciados tinha por consequência uma paralisia institucional, principalmente quando estavam envolvidos fortes interesses econômicos.

Na prática, de acordo com o relatório da Organização das Nações Unidas para a Educação, a Ciência e a Cultura sobre o tema (Unesco, 2005), tal paralisia evidencia a recusa de se pôr em prática o princípio da precaução, que impõe a primazia da proteção da vida sobre atividades humanas que possam ocasionar perigos moralmente inaceitáveis, os quais são cientificamente plausíveis, mas apresentam elevadas incertezas socioambientais.

Essa concepção precaucionária e da primazia da vida está diretamente relacionada à concepção ampliada de saúde que defendemos em nosso projeto, a qual reflete não só a dimensão biomédica dos impactos ambientais, mas questões relacionadas à qualidade de vida, à cultura e tradições, aos direitos humanos e à capacidade de organização e mobilização coletivas. Ou seja, além das doenças diagnosticadas, a saúde está ligada à qualidade de vida, ao direito à participação, à democracia, à cultura e à defesa da natureza e da qualidade ambiental.

Ao observarmos os desafios da participação do Estado, podem-se identificar alguns pontos de tensão. Um deles se refere às concepções encontradas no mapa sobre o papel do Estado e sobre a maneira como o conceito de saúde deve ser interpretado e incorporado no âmbito das políticas públicas, de forma a propor uma ação integrada e democratizante. Também constituem ponto de tensão as dificuldades em se incorporar os referenciais teóricopolítico e metodológicos necessários à leitura e explicitação de conflito e de 
racismo ambientais que evidenciam as injustiças e a urgente necessidade de se promover a justiça ambiental como questão determinante para se garantir saúde pública.

O terceiro ponto se refere às pressões reais de grupos econômicos, por dentro e por fora do Estado, a despeito da legitimidade da iniciativa de construção do mapa como esforço coletivo de democratização das políticas. Tais pressões exigem uma atenção redobrada por parte dos órgãos e gestores públicos em seus papéis de fiscalização, mediação e negociação, já que, em situações de injustiça, a atuação ocorre em contextos contraditórios e assimétricos que podem comprometer a defesa do bem público, da saúde e do conjunto dos direitos humanos fundamentais. Reforça-se, assim, o papel dos pesquisadores e demais sujeitos envolvidos na construção e nos propósitos do mapa para atuarem na defesa solidária das populações atingidas.

\section{Desdobramentos, Continuidade e Perspectivas para o Mapa}

Uma vez lançado na Internet, já se previa para o mapa uma continuidade óbvia: a atualização dos 297 conflitos, à que se somaria o trabalho com as novas denúncias recebidas, e consideradas válidas, de acordo com os objetivos anunciados.

Também estava já previsto no projeto que alguns conflitos, pelas suas especificidades e abrangências, receberiam um tratamento especial. Seriam produzidos mapas temáticos para casos que envolvessem mais de um estado com uma mesma problemática. Dois deles eram candidatos certos a esse tratamento: a transposição do rio São Francisco e a ação da companhia Vale (do Rio Doce), a começar pela região de Carajás.

Essa segunda questão começou a ser discutida na lista do GT Articulação Mineração e Siderurgia, com as entidades ligadas à Campanha Justiça nos Trilhos (www.justicanostrilhos.org). Ao mesmo tempo, foi iniciada uma troca de informações com entidades parceiras da Bahia, trabalhando com a hipótese de começar a organização dos dados sobre os conflitos ambientais em torno da transposição do São Francisco ainda no primeiro semestre de 2010. Dificuldades para obter recursos, entretanto, levaram ao adiamento do projeto. Mas essa é uma das mais importantes perspectivas de continuidade do mapa e, como tal, deve ser viabilizada e levada a cabo. De qualquer forma, o mapa permite que quaisquer pessoas ou entidades interessadas em temáticas específicas possam levantar todos os conflitos que tenham a palavra-chave pesquisada em seu conteúdo, como, por exemplo, 'quilombolas', 'mineração', 'transposição', 'povos indígenas' etc. 
As respostas ao mapa na Internet e a projeção que ele foi ganhando se desdobraram em importantes articulações e diálogos estratégicos entre os diferentes sujeitos de lutas contra as injustiças e o racismo ambiental. Depois do primeiro lançamento, organizado pelo GT Combate ao Racismo Ambiental em março de 2010, na Universidade Federal do Ceará, em Fortaleza, seguiram-se diversos outros, entre os quais: em abril, na Assembleia Legislativa de São Paulo, organizado pela Associação Brasileira de Expostos ao Amianto - Abrea, ${ }^{2}$ e em Salvador, organizado pelo Instituto de Gestão das Águas e Climas (Ingá); ${ }^{3}$ em maio, no Rio de Janeiro, na sede da Fiocruz, em Manguinhos; em junho, na Universidade Federal Rural do Rio de Janeiro; em julho, em Mauá, São Paulo, organizado pela Secretaria de Meio Ambiente e pela prefeitura local; em setembro, no Congresso Agrotóxicos, Saúde e Meio Ambiente: o direito à informação, em Várzea Grande, Mato Grosso; em outubro, no Seminário Efetividade de Estratégias de Desenvolvimento Sustentável e Promoção da Saúde, em Parati, Rio de Janeiro; e em dezembro, no I Simpósio Brasileiro de Saúde Ambiental da Associação Brasileira de Saúde Coletiva (Abrasco), em Belém do Pará.

Um trabalho especial, inicialmente voltado para o campesinato e para os agricultores familiares ligados à agroecologia, também começou a ser desenvolvido em etapas, a partir de setembro de 2010, sob a organização da Articulação Nacional de Agroecologia (ANA). Por meio desse trabalho, o debate sobre o mapa esteve inserido em três oficinas territoriais realizadas no Agreste da Paraíba, no Planalto Serrano de Santa Catarina e no norte de Minas Gerais, todas preparatórias para o Encontro Nacional Diálogos e Convergências entre Movimentos e Redes Sociais, realizado em setembro de 2011, na Bahia. O evento foi uma realização conjunta, estimulada pela ANA, do qual participaram inúmeros movimentos e redes sociais, como a RBJA, o Fórum Brasileiro de Economia Solidária, o Fórum de Segurança e Soberania Alimentar, a Rede Alerta Contra o Deserto Verde, a Associação Brasileira de Agroecologia, o Movimento de Mulheres Camponesas, a Abrasco, entre outros.

Em todas as oficinas territoriais preparatórias, a avaliação final envolveu dois dados relevantes: para os participantes, a questão do território, antes encarada como mero cenário de suas lutas, adquiriu uma nova importância e, no dizer de alguns, um caráter de centralidade. Mais que isso, entretanto,

\footnotetext{
${ }^{2}$ Ver em: <www.abrea.com.br>.

${ }^{3}$ Órgão estadual vinculado ao governo da Bahia, pouco depois extinto, que, na época, cuidava das questões referentes a recursos hídricos.
} 
todos acentuaram o fato de que deveriam, a partir daquele momento, incluir, nas suas análises e estratégias, o reconhecimento de outros atores - povos indígenas, quilombolas e comunidades tradicionais - como aliados e parceiros no embate pela democratização do território e pela cidadania. Essa iniciativa estende o alcance do mapa, pois o insere em uma proposta ampla de se pensar os territórios levando em conta os interesses dos movimentos sociais dentro do que tem sido chamado de 'intermapas dos movimentos sociais'.

A proposta é integrar, em um mapa virtual (o Intermapas), os diferentes mapeamentos produzidos em articulação com movimentos sociais, e os dados georreferenciados usando a plataforma do Google Maps. A proposta inicial do Intermapas foi articular os dados de quatro mapas: o de Injustiça Ambiental e Saúde (que apresenta a dimensão dos conflitos e o lado crítico do desenvolvimento nos territórios); a chamada Plataforma BNDES (coordenada pelo Instituto Brasileiro de Análises Sociais e Econômicas, o Ibase, faz um levantamento crítico de informações sobre projetos de desenvolvimento apoiados pelo banco); o Farejador da Economia Solidária do Fórum Brasileiro de Economia Solidária (FBES) e o Agroecologia em Rede (que apresentam alternativas de desenvolvimento ligadas à economia solidária e à agroecologia). Esses mapas têm características bem distintas: atualmente o Mapa de Conflitos está sendo atualizado e ampliado, e os da Economia Solidária e do Banco Nacional de Desenvolvimento Econômico e Social (BNDES) têm maior dificuldade para atualização e/ou continuidade. Todos esses projetos estão disponíveis na Internet (www.plataformabndes.org.br; www.fbes.org.br; e www.agroecologiaemrede.org.br), e sua continuidade foi discutida no Encontro Diálogos e Convergências entre Movimentos e Redes Sociais, já mencionado. Uma primeira versão do Intermapas foi desenvolvida para o encontro, e pode ser acessada na Internet (www.fbes. org.br/intermapas). ${ }^{4}$

Ao ampliar o universo pesquisado, agregando a ele informações provenientes de outros instrumentos, ainda que criados com base em diferentes visões, o Intermapas revela um quadro amplo do território investigado do ponto de vista dos conflitos, ou seja, das disputas por recursos e modelos de desenvolvimento travadas nos territórios. Isso inclui as resistências, mobilizações e alternativas na construção de outras economias e modelos de sociedade diante dos impactos gerados por empreendimentos econômicos e políticas que os apoiam. No Intermapas, é possível reunir, além da informação

${ }^{4}$ O Intermapas não seria sequer visto como uma possibilidade sem a capacidade de sonhar, de assumir desafios, de Daniel Tygel, do FBES, seu principal mentor e operacionalizador. 
buscada, a possibilidade de acesso a diversas outras complementares. Um exemplo: ao se digitar no mapa as palavras 'UHE Belo Monte', pode-se não só ter acesso aos conflitos que envolvem injustiça ambiental e saúde como também saber se há centros de agroecologia que serão afetados por ela, ou como e com quanto o BNDES está colaborando para o financiamento da sua construção.

OMapa de Conflitos Envolvendo Injustiça AmbientaleSaúdeno Brasil especificamente, ainda em novembro de 2010, foi tema de abertura da IV Jornada Ecumênica, que reuniu cerca de quatrocentas pessoas principalmente da América Latina (havia também participantes da Europa), em Itaici, São Paulo. Isso ensejou um novo caminho: o convite para que sua apresentação também abrisse o Encontro Nacional do Conselho Interamericano de Igrejas (Clai-Brasil), no final de maio de 2011, também em São Paulo. Conquistar a indignação e a mobilização das diferentes igrejas, assim como de integrantes de outras religiões, como as de matriz africana (também presentes em Itaici) pode ser entendido sem dúvida como importante conquista.

Outro campo de ação efetiva se abriria ao longo desses meses. Em abril de 2010, durante a realização do Encontro com @s Advogad@s Populares, organizado pelo GT Combate ao Racismo Ambiental em Salvador, a apresentação do mapa levou as diversas entidades presentes (Associação de Advogadas e Advogados de Trabalhadores Rurais - AATR -, Rede Nacional de Advogadas e Advogados Populares - Renap -, Dignitatis Assessoria Técnica Popular, Justiça Global e Terra de Direitos) a verem de forma especial sua importância. Revelava-se, para eles, uma nova forma de encarar não só as lutas que povos indígenas, quilombolas e comunidades tradicionais, principalmente, enfrentam, em boa parte tendo-os como parceiros e aliados, como tantos outros conflitos dos quais em muitos casos não tinham conhecimento. E, ainda, a realidade de estados onde a ação da própria Renap - a de maior abrangência entre as cinco organizações - é apenas pontual.

Como resultado, apresentações do mapa passaram a ser marcadas em diferentes regiões, começando por uma breve amostra não agendada no próprio seminário da AATR, que aconteceu no dia seguinte ao término do Encontro com @s Advogad@s Populares. Daí viria a abertura de um espaço especial para sua apresentação no Encontro Nacional da Renap, em Luziânia, Goiás, em julho de 2010, seguida de outra no Seminário Terra e Território, organizado pela Dignitatis Assessoria Técnica Popular e pelo Instituto Nacional de Colonização e Reforma Agrária (Incra), em João Pessoa, na Paraíba, em agosto. 
Esses espaços de reflexão representaram um grande passo político, fortalecendo e/ou conquistando os advogados populares na defesa das comunidades. Numa dessas apresentações mostrou-se que, nos estudos sobre os conflitos, os ministérios públicos federais e estaduais eram os grandes defensores dos atingidos (179 dos 297 casos), ${ }^{5}$ ao passo que as defensorias públicas estavam presentes em apenas nove conflitos, e, em um deles, apoiava os fazendeiros e ia contra o povo indígena e o próprio Ministério Público. A repercussão dessa informação transformou o mapa em um dos principais 'atores' do I Encontro Nacional de Defensores Públicos em Direitos Humanos e Tutela Coletiva, realizado em setembro de 2010, em Fortaleza.

Mas não foram somente advogados populares e defensores públicos que se interessaram pelas análises dos dados contidos no mapa e pelas reflexões a que ele levava. Em diversos eventos promovidos em universidades e centros de estudos, entre outros locais - começando pelas oficinas sobre racismo ambiental e se desdobrando em encontros e seminários sobre a questão urbana, a agricultura familiar, os agrotóxicos - o mapa continuava cumprindo seu papel de denúncia e de mobilização. Ao mesmo tempo que, para muitos, desvelava outro retrato do Brasil e dos embates existentes em seus territórios, deixava clara também sua faceta de instrumento de luta, como sempre fora pensado, de modo que algumas entidades começaram a buscar nele a inspiração e a metodologia para a construção de mapas estaduais.

Essa hipótese veio ao encontro de uma proposta já pensada e que, além de possibilitar que se abrisse mão do validador permitiria principalmente que o papel a ser desempenhado pelo mapa fosse potencializado em sua articulação com as entidades que atuam nos movimentos contra a injustiça e o racismo ambiental no Brasil. Essa perspectiva esteve presente desde o início de sua concepção, com a Fase e a secretaria executiva da RBJA presentes na idealização e desdobramentos do projeto. Isso significava, além de ampliar as denúncias do mapa, manter atualizados os conflitos já divulgados e, acima de tudo, democratizar seu potencial e socializá-lo com um leque cada vez maior de parceiros e comunidades, integrando-os nos movimentos contra a injustiça, o racismo e pela justiça ambiental.

É importante considerar que, muitas vezes, as origens e as responsabilidades pelos conflitos se repetem em diferentes locais, porém, as lutas ainda se

\footnotetext{
${ }^{5}$ Os ministérios públicos estadual e federal estão de alguma forma presentes em 210 conflitos. Em 31 deles, entretanto, assumiram posições que levaram as comunidades envolvidas a considerá-los corresponsáveis pelos danos causados a elas.
} 
dão de forma atomizada, na medida em que as comunidades sequer têm conhecimento desses pontos em comum. Socializar a informação, nesses casos, permite não só analisar de forma correta a teia que o capitalismo tece no território, rural e urbano, mas também vislumbrar alternativas e estratégias bem-sucedidas em alguns locais, derrotadas em outros -, e aprender com elas.

Quanto ao Mapa de Conflitos, nova fase de diálogos e de trabalho político tem se aberto. Embora partilhar experiências e metodologias seja uma das tarefas a que o mapa se propõe (e o caráter, muitas vezes, quase didático deste livro é prova disso), do ponto de vista estratégico é interessante considerar que, talvez, a melhor tática não seja uma coleção de mapas estaduais dissociados, muitas vezes retratando conflitos que extrapolam seus limites geográficos. Isso pode até mesmo reproduzir o fracionamento da capacidade de reflexão e de luta, já que muitos conflitos envolvem lógicas e poderes extraterritoriais, além de uma multiplicação desnecessária de gastos. Com isso, não estamos de forma alguma negando a importância das iniciativas locais de mapeamento e organização dos conflitos ambientais e das violações que a eles são inerentes; mas há algumas ponderações a serem feitas a esse respeito.

Mapas regionais e estaduais, como o Mapa dos Conflitos Ambientais do Estado de Minas Gerais, ${ }^{6}$ lançado em junho de 2011, representam a possibilidade de levantar um maior número de conflitos e casos de injustiça ambiental, de forma a captar várias dinâmicas e detalhes em nível mais local. Seguindo o exemplo do Mapa dos Conflitos do Rio de Janeiro, já mencionado, para o mapa de Minas foram selecionados pelos pesquisadores 541 casos, ocorridos entre 2000 e 2010.

Na versão inicial do Mapa de Conflitos, o estado de Minas estava presente com apenas 23 conflitos. Entretanto, muitos desses 23 incluem simultaneamente inúmeros casos do mapa mineiro, pois agregam, em único conflito, vários territórios e populações atingidas por um grande impacto ou empreendimento. E isso quando não se espraiam por outro estado, como é o caso do porto do Açu, que abrange, em um só conflito, um total de 32 municípios, mineiros e fluminenses.

Dessa forma, os mapas se complementariam: os nacionais dariam maior destaque a casos paradigmáticos ou simbólicos e poderiam agregar informações por grandes conflitos que envolvem simultaneamente vários

\footnotetext{
${ }^{6}$ Ver em: <www.conflitosambientaismg.lcc.ufmg.br>. O Mapa dos Conflitos Ambientais do Estado de Minas Gerais foi elaborado pelo Grupo de Estudos em Temáticas Ambientais (Gesta/UFMG), em parceria com o Núcleo de Investigações em Justiça Ambiental da Universidade Federal de São João del-Rei (Ninja/UFSJ) e a Universidade Estadual de Montes Claros, entre 2007 e 2010.
} 
atores, municípios ou estados, ao passo que os estaduais ou regionais lançariam uma 'lente de aumento' no território, com maior detalhamento de informações de nível mais local, ao mesmo tempo que permitiriam maior interação com os sujeitos locais.

Porém, devemos pensar isso de forma estratégica para não corrermos os riscos de reproduzir o fracionamento da capacidade de reflexão e de luta e multiplicarmos desnecessariamente os gastos com iniciativas que poderiam acontecer de forma articulada. Devemos levar em conta ainda uma questão prática: o Mapa de Conflitos é um instrumento público. Então, por que não utilizá-lo, aprofundando institucionalmente parcerias estaduais e compartilhando com elas a responsabilidade de introduzir novos casos e de atualizar os já registrados no mapa nacional?

Foi nesse esforço de se construir estratégias articuladas de luta que se promoveram os diálogos com entidades de alguns estados, fazendo surgir, no início de 2011, a primeira proposta concreta de capilarizar o mapa. Ao final de uma oficina realizada no dia 18 de janeiro, na Universidade Federal do Maranhão (UFMA), as diversas organizações locais presentes decidiriam criar o Núcleo Maranhense do Mapa de Conflitos, integrado inicialmente pelas seguintes entidades (a maioria atuante no âmbito da RBJA): Movimento Popular de Saúde (Mops); Fórum Carajás; Campanha Justiça nos Trilhos; Grupo de Estudos Desenvolvimento, Modernidade e Meio Ambiente (GEDMMA), da UFMA; e o Movimento dos Trabalhadores Sem Terra (MST). Outras entidades presentes na ocasião decidiram participar como colaboradoras, ao mesmo tempo que se aprovava o núcleo como um parceiro efetivo, responsabilizando-o pelo acompanhamento e atualização dos conflitos já registrados no estado, pela definição de novos casos a serem priorizados e pelo levantamento dos dados referentes a eles, para que fossem inseridos no mapa.

Ainda em 2011, o embrião de um novo núcleo seria criado no Departamento de Saúde Coletiva da Faculdade de Ciências da Saúde da Universidade de Brasília. Espontaneamente, o departamento se reuniu e iniciou uma pesquisa sobre o caso da Cidade Estrutural, envolvendo catadores de materiais recicláveis e a poluição provocada por um depósito de lixo. Elaborado de acordo com a metodologia e os critérios utilizados para a pesquisa e o 'fichamento' dos conflitos, o caso da Estrutural inaugurou, além do sucesso da parceria, a presença do Distrito Federal no mapa. O diálogo continua com outros estados, na expectativa de que a organização de núcleos estaduais seja um caminho para uma nova série de articulações, parcerias e vitórias. 
A participação da equipe do mapa em oficinas, seminários e encontros com os movimentos por justiça ambiental - e com a RBJA, especificamente-, ao mesmo tempo dá continuidade e amplia um processo organicamente construído desde a sua origem. Nesse sentido, consideramos a relação sinérgica entre o Mapa de Conflitos e a Relatoria de Direitos Humanos ao Meio Ambiente um exemplo emblemático da capacidade de o mapa fomentar novos processos. Desde o início do projeto Plataforma Brasileira de Direitos Humanos Econômicos, Sociais, Culturais e Ambientais (Dhesca Brasil), ${ }^{7}$ a RBJA tem cumprido papel de referência para a Relatoria de Direito Humano ao Meio Ambiente, pautando tematicamente suas missões e participando ativamente da construção delas.

Se os primeiros relatórios foram usados como fontes de informação para o mapa, ultimamente a relação se inverteu. Ações relacionadas ao monitoramento de atividades do ciclo de produção nuclear, por exemplo, estiveram articuladas ao processo de produção de informações sobre os conflitos a serem divulgados nele. Ao identificar atores e oferecer subsídios à relatoria, o mapa contribuiu para ampliar a visibilidade das violações de direitos relacionadas a essas atividades, articular saberes e experiências de resistência, mostrar propostas formuladas por atores políticos que vivenciam conflitos e violações similares, e fortalecer, assim, as lutas travadas localmente.

Em uma perspectiva de continuidade, o mapa tenderá cada vez mais a, ao mesmo tempo, pautar e ser pautado, propondo temas ainda não tão presentes na agenda da rede, mas diretamente relacionados à discussão sobre saúde ambiental, tais como: o enfrentamento das injustiças climáticas; o caráter excludente e discriminatório das novas tecnologias; e a compreensão das desigualdades de gênero e da divisão sexual do trabalho como elementos estruturantes das injustiças ambientais.

Em termos institucionais, um novo desafio será proposto a partir de 2013. Sempre intermediado pela presidência da Fiocruz, desde o início de sua construção até meados de 2012, o Mapa de Conflitos teve o apoio do Departamento de Vigilância em Saúde Ambiental e Saúde do Trabalhador do Ministério da Saúde. Nos próximos anos, entretanto, o apoio será da Secretaria de Gestão Estratégica e Participativa (SGEP), cuja missão está voltada para a participação popular, o controle social e a resposta às demandas dos usuários do Sistema Único de Saúde (SUS). Esperamos que,

\footnotetext{
${ }^{7}$ Ver em: <www.dhescbrasil.org.br $>$.
} 
com essa articulação, o mapa possa ser uma valiosa fonte de informações para o Ministério da Saúde e o SUS, que poderão incorporar na construção de políticas de saúde, de forma integrada, questões como a dimensão territorial, e a luta contra a injustiça e o racismo ambiental.

Afora o alcance nacional, o mapa também tem demonstrado ser de grande valia para centros e entidades internacionais interessados nos conflitos e injustiças ambientais. Além de ter sido apresentado no Centro de Estudos Sociais da Universidade de Coimbra, criado pelo sociólogo português Boaventura de Souza Santos, o Mapa de Conflitos vem contribuindo para o desenvolvimento do projeto intitulado Environmental Justice Organizations, Liabilities and Trade (EJOLT), ${ }^{8}$ coordenado na Universidade de Barcelona por Joan Martinez-Alier. O projeto reúne um consórcio internacional de atores (cientistas, organizações ativistas, grupos de reflexão, dentre outros) em uma série de áreas de conhecimento (direito ambiental, saúde ambiental, ecologia política e economia ecológica). A ideia é compartilhar conhecimentos e experiências integrando ciência e ativismo em torno dos conflitos ambientais e de ações por justiça ambiental, bases para o desenvolvimento das ciências da sustentabilidade. Entre os temas privilegiados encontramse os conflitos de distribuição ecológica, as dívidas ecológicas e o comércio ecologicamente desigual e injusto.

Está previsto o lançamento ainda em 2013 de um Mapa de Injustiça Ambiental que permitirá, em virtude de seu alcance mundial e da inclusão de fundamentos da ecologia política, como o metabolismo social, compreender os conflitos ambientais considerando as características do comércio internacional. Muitos conflitos decorrem da exploração de recursos naturais em países da América Latina, África e Ásia, que acabam exportando commodities agrícolas e metálicas com um lastro de destruição ambiental e desrespeito aos direitos das populações locais. Além de informações do Mapa de Conflitos brasileiro, o EJOLT também conta com contribuições de mapas produzidos por organizações como o Observatorio de Conflictos Mineros de América Latina (OCMAL), sediado na Acción Ecológica, importante organização equatoriana de justiça ambiental; ${ }^{9}$ e o italiano Centro de Documentação de Conflitos Ambientais (CDCA), cujo mapa se concentra em conflitos com a participação de empresas multinacionais que exploram recursos naturais nos países do 'sul global'. ${ }^{10}$

\footnotetext{
${ }^{8}$ Ver em: $<w w w . e j o l t . o r g>$.

${ }^{9}$ Ver em: $<w w w . c o n f l i c t o s m i n e r o s . n e t>$.

${ }^{10}$ Ver em: <www.cdca.it/spip.php?rubrique111\&lang=en $>$.
} 


\section{Observações Finais}

Neste capítulo, discutimos a relevância da iniciativa do Mapa de Conflitos para a movimentação social e para as políticas públicas à luz da cidadania que defendemos em sua efetividade democrática. Obviamente, estamos cientes de suas limitações e temos a clareza de que não se trata do instrumento máximo, mas de uma iniciativa que se soma a muitas outras, levadas a cabo por cidadãos organizados que buscam recolocar em cena pública problemas comuns e diferentes formas de abordá-los.

É obvio também que o aprimoramento de uma iniciativa como a do mapa depende de uma série de fatores, tais como: os desafios postos para a participação dos atingidos, não só oferecendo informações, mas incidindo nos seus rumos políticos e metodológicos; a garantia de que a sociedade efetivamente dele tome posse, das mais variadas formas; de que o Estado mantenha seu apoio e de que outros sejam incorporados.

Contudo, no contexto das degradações sociais e ambientais e dos mecanismos que lhes dão origem, fazem-se obrigatórias a reflexão sobre o modelo de sociedade que predomina em nossos tempos e a ação crítica contra ele. Questionar esse modelo e revelar suas faces perversas é, a nosso ver, a diretriz ética pela qual realmente se pode chegar à reconstrução dos caminhos da cidadania e da democracia. E o primeiro passo para isso é combater as injustiças, inaceitáveis para nossa condição humana e necessidade de bem viver, ambas ameaçadas pela cultura mercadológica e pela banalização das violências e perdas, que atingem os desfavorecidos nos embates políticos, sociais e econômicos.

O mais importante neste debate, do qual o Mapa de Conflitos é partícipe, é saber que a força de intervenção na realidade está fortemente vinculada à capacidade dos sujeitos políticos das lutas sociais, das instituições e dos profissionais engajados de se 'encontrarem' mesmo diante de tantas desigualdades. E esse encontro requer muito mais que apenas estar face a face. É necessário que se façam ouvir, que se demarquem pautas comuns, que se afine o discurso ético-político da transformação social e, finalmente, que se realizem, ainda que geograficamente distantes, ações coletivas orquestradas contra as injustiças. Desse ponto de vista, todas as iniciativas para fortalecer esse processo político, cidadão e democrático são mais do que bem-vindas, são absolutamente necessárias, para não dizer imperiosas. 


\section{Referências}

JELIN, E. Mulheres e direitos humanos. Revista Estudos Feministas, 2(3): 117-149, 1994.

RANCIÈRE, J. Democracia ou consenso. In: RANCIÈRE, J. O Desentendimento. São Paulo: Editora 34, 1996.

SCOTT, J. W. A invisibilidade da experiência. Projeto História, 16: 297-325, 1998.

UNESCO (ORGANIZAÇÃO DAS NAÇÕES UNIDAS PARA A EDUCAÇÃO, A CIÊNCIA E A CULTURA). The Precautionary Principle. Paris: Unesco, 2005. 


\title{
8
}

\section{Mapeando Alternativas para o Futuro}

\author{
Jean Pierre Leroy \\ Tania Pacheco \\ Marcelo Firpo Porto \\ Diogo Rocha
}

$\mathrm{O}$

Mapa de Conflitos Envolvendo Injustiça Ambiental e Saúde no Brasil (ou Mapa de Conflitos) ${ }^{1}$ apresenta um preocupante quadro das agressões causadas pelos diferentes projetos e empreendimentos que caracterizam o atual modelo de desenvolvimento. Ao mesmo tempo, porém, revela exemplos admiráveis de enfrentamento por parte das populações e comunidades, tanto do campo como das cidades. As conjunturas nacional e internacional, assim como as perspectivas que as diversas crises (da estrutural à climática) indicam, permitem vislumbrar uma melhoria da situação atual ou prever a continuidade ou mesmo o agravamento das atuais injustiças?

Lamentavelmente, prevê-se longa vida para o mapa. Segundo seus coordenadores, ele só perderá sua razão de ser quando a nossa concepção de mundo tiver sido revolucionada, levando a uma alteração radical nas políticas públicas. Enquanto isso não acontecer, as causas se reproduzirão e se multiplicarão os conflitos. E, na verdade, somam-se ao quadro econômico dimensões políticas, culturais e éticas que nos levam a afirmar que ainda estamos dando os primeiros passos em direção a essa 'revolução'.

Na formação do capitalismo industrial e no seu desenvolvimento se viu adquirir vigor o sindicalismo que forçou o reconhecimento de amplos direitos humanos, em particular na área do trabalho. Hoje, o mundo

\footnotetext{
${ }^{1}$ Disponível em: <www.conflitoambiental.icict.fiocruz.br>.
} 
conhece uma regressão sem precedentes desses direitos, ao mesmo tempo que os explorados, os invisíveis, os 'atrasados' - povos indígenas, quilombolas, comunidades tradicionais, populações das periferias urbanas -, assim como mulheres e jovens reivindicam com novo fôlego seus novos/ antigos direitos.

O reconhecimento da crise ambiental e os avanços prometidos após os vários marcos das últimas décadas - como as publicações Primavera Silenciosa (Carson, 2010) e Nosso Futuro Comum (Comissão Mundial sobre Meio Ambiente e Desenvolvimento, 1991) ou, ainda, a Conferência das Nações Unidas sobre o Meio Ambiente e o Desenvolvimento, conhecida também como ECO-92, Rio-92, - têm sido refreados por um ambientalismo de mercado que centra suas grandes soluções numa economia 'verde' e 'sem carbono', que desconsidera ou oculta os conflitos, as injustiças e as necessidades da vida em suas múltiplas dimensões.

Apesar dos retrocessos, há que se admitir que muitas das agendas atualmente colocadas por movimentos sociais e ambientais avançaram em sua capacidade de reconhecer e dialogar com questões fundamentais, antes desprezadas ou omitidas - como os direitos das comunidades tradicionais (incluindo as camponesas), indígenas e quilombolas-, que contribuem de forma central para o questionamento do modelo de desenvolvimento, baseado na busca obsessiva pelo crescimento econômico e na perda de valores sociais e interpessoais pautados na solidariedade e no respeito pela natureza.

Em contrapartida, tais avanços têm sido alvo de grupos econômicos e políticos conservadores que atuam até mesmo para promover recuos na legislação, tal como fizeram recentemente com o Código Florestal e continuam a fazer, de forma crescente, em relação à demarcação de terras indígenas e quilombolas, ao Código de Mineração e à própria legislação ambiental no âmbito federal e estadual. Assim, será necessária toda a atenção para que maiores retrocessos não ocorram nos próximos anos.

Não há linearidade na evolução histórica da humanidade e, portanto, o pior nem sempre se realiza, mas, sem dúvida, o cenário político e econômico não é muito propício para que se possa pensar numa drástica redução dos casos de injustiça ambiental e na melhoria da saúde individual e coletiva, que sempre se interconectam. Porém, a dialética das crises e as alternativas construídas no cotidiano das resistências poderão apontar luzes de um túnel cujo fim não nos aparece com clareza, até mesmo porque as crises são amplas e refletem uma crise civilizatória maior. 
Alguns avanços recentes, como a manutenção e mesmo o reforço das políticas sociais compensatórias dos últimos governos, a retomada do emprego, pequenos progressos na política habitacional, a atenção dada à agricultura familiar/camponesa, poderiam nos levar a uma visão otimista se não fossem decorrentes do tipo de crescimento experimentado pelo Brasil. Isso também pode ser dito em relação ao reconhecimento dos direitos dos povos indígenas, quilombolas, das comunidades tradicionais e camponesas: o modelo de desenvolvimento utilizado para esse 'crescimento' é precisamente a causa principal das injustiças elencadas no Mapa de Conflitos, das quais eles são as vítimas majoritárias, além dos moradores e trabalhadores das periferias onde se encontram as 'zonas de sacrifício'. Portanto, a busca obsessiva pelo crescimento, realizada mediante o ocultamento ou desprezo dos impactos e dos sacrificados, é uma marca inevitável para o 'sucesso' desse modelo insustentável e iníquo.

A atuação crescente do Ministério Público, federal e estadual, assim como a regulamentação das defensorias públicas e de suas ouvidorias externas, legalmente responsáveis pelos direitos e tutelas coletivos, seriam alentadoras se, de fato, fossem totalmente respeitadas. No entanto, o que vemos, na luta pelo território que cada vez mais caracteriza o nosso cenário, é uma violência brutal que não dá sinal de arrefecimento e na qual a impunidade continua a prevalecer na maioria dos casos.

A crescente tomada de consciência sobre a importância do meio ambiente e sobre os impactos negativos na saúde produzidos pelo modelo de produção dominante seria promissora se não fosse subsumida pela crise permanente da saúde curativa e pela forma permissiva como os licenciamentos ambientais são concedidos. Com base nos casos registrados no mapa, podem-se identificar pelo menos três campos de análise que suscitam a nossa inquietação quanto ao futuro: o econômico, o político e o ético-filosófico.

\section{As Ameaças do Crescimento}

Em 2007, veio à tona a bolha imobiliária nos Estados Unidos, que escancarou a 'orgia' do sistema bancário internacional e a incapacidade dos governos de responder de forma republicana a uma crise muito mais profunda. As economias estadunidense e europeia estiveram próximas do colapso ou, pelo menos, degradaram consideravelmente as condições de vida da maioria dos seus cidadãos. Se os Estados Unidos retomam, mesmo que muito lentamente e de maneira desigual, seu crescimento, a Europa continua sem perspectivas, com alto índice de desemprego, em particular nos países 
do sul da União Europeia. Movimentos sociais explodiram e continuam a pontuar a crise, desde o chamado 'coração do capitalismo', os Estados Unidos da Wall Street e do movimento Occupy.

A crise desencadeou consequências severas também em outros países. A China, em particular, está sendo obrigada a reduzir a velocidade de crescimento. O Brasil, que tem a China como um grande consumidor das suas commodities, vê-se obrigado a rever suas projeções. Em uma análise superficial, isso pode não ser considerado um problema tão sério, uma vez que boa parte da nossa economia é sustentada pela exportação de commodities agrícolas, e a humanidade, de qualquer modo, precisa se alimentar. Contudo, como o Mapa de Conflitos também nos mostra, o atual modelo de produção e consumo de alimentos está bem longe de ser justo e sustentável.

Essa conjuntura reforçou a política governamental de, além de socializar os prejuízos do setor financeiro, incentivar o consumo - numa solução já posta em prática no momento da crise norte-americana de 2007/2008 - e acentuar a industrialização voltada para o mercado interno. Mas o que chama a atenção é que, no Brasil e no mundo todo, aspira-se a retomar ou acelerar o crescimento, a única via entendida como solução. Mas, afinal de contas, crescimento como, para que e para quem? O que ele nos anuncia? Essas são questões centrais para compreendermos os conflitos e as injustiças ambientais no contexto brasileiro.

A produção de energia é causa importante de injustiça ambiental, como podemos ver no mapa. As projeções do Plano Decenal de Energia para o período 2010-2019 indicam que a tendência é de recrudescimento de conflitos, ainda mais em um contexto de desregulação ambiental, de que trataremos a seguir.

O Plano Decenal prevê que o incremento anual médio do Produto Interno Bruto (PIB) brasileiro no decênio 2010-2019 seja de 5,1\% (Brasil, 2010). Para a eletricidade, no mesmo período, a taxa média de crescimento do consumo estimada é de 5,0\% ao ano. A hidroeletricidade contribuiria para satisfazer essa demanda com 61 projetos hidroelétricos, estejam eles em construção, concedidos ou planejados (Brasil, 2010), sem mencionar dezenas de pequenas centrais hidroelétricas (PCHs) já construídas ou previstas.

O Plano Decenal prevê ainda que exatos 108.991 habitantes serão afetados pela geração elétrica. No entanto, sabemos o quanto as estimativas oficiais são subestimadas para que o ônus socioambiental dos empreendimentos pese o menos possível sobre os custos. Às diferentes populações atingidas pelas barragens, teremos que acrescentar as pessoas e comunidades, na maioria 
de baixa renda, impactadas pelos desmatamentos, pela extração de carvão e pela poluição causada no entorno das termelétricas. Ao mesmo tempo, o Plano Decenal assume uma lógica linear entre projeção de crescimento econômico e aumento da produção de energia, seja ela de onde for, até mesmo por via da expansão de usinas nucleares no país, num momento em que o mundo pós-catástrofe de Fukushima questiona a continuidade de uso dessa energia, que vinha sendo 'vendida' por sua indústria como uma das alternativas mais 'sustentáveis'.

Além disso, não se discutem no Plano Decenal o sentido e os patamares para uma produção de energia sustentável que garanta qualidade de vida ao conjunto da população e não gere injustiças ambientais. Em 2010, o Brasil alcançou a maior produção per capita de energia em sua história - 52,9 gigajoules por habitante-, um número ainda bem inferior ao dos países mais industrializados da América do Norte e da Europa (IBGE, 2012). Portanto, seguindo o padrão econômico desses países, baseado no crescimento do consumo e dos lucros, os conflitos e a insustentabilidade só aumentarão. Isso demonstra a dimensão civilizatória da crise socioambiental: em vez de discutir e incentivar o crescimento econômico e a exploração de petróleo caso do pré-sal-, o que deveríamos fazer é construir os alicerces de uma nova economia mais solidária e sustentável. Na atual corrente, ainda que mais investimentos em educação ocorram, os futuros 'beneficiados' deverão lidar com as tragédias decorrentes desse modelo energético industrial.

No campo da agricultura, o presidente para a América Latina da multinacional Nufarm Indústria Química, Valdemar Fischer, estimava em 2010 que a indústria de defensivos no Brasil poderia expandir-se de 4 a $5 \%$ sobre o faturamento de US \$ 6,6 bilhões registrados em 2009 (Agência Estado, 2010). De fato, segundo dados levantados pela Associação Brasileira de Saúde Coletiva (Abrasco), "em 2010, o mercado nacional movimentou cerca de US\$7,3 bilhões" (Vitali et al., 2012), e chegou a mais de US\$ 8 bilhões em 2011.

Contrariando o otimismo das multinacionais do setor quanto ao futuro, pode-se prever o aumento de gravíssimos problemas de saúde pública já em curso, em parte registrados no mapa. Os impactos desses problemas e as alternativas para eles têm sido amplamente discutidos na sociedade pela Campanha Permanente Contra o Uso de Agrotóxicos no Brasil. ${ }^{2} \mathrm{Na}$ fronteira do agronegócio, o Fórum Direitos Humanos e da Terra de Mato Grosso (2011) denuncia que no estado "são aplicados anualmente 46,2 quilos de agrotóxicos

\footnotetext{
${ }^{2}$ Ver em: <www.mst.org.br/Campanha-contra-o-uso-de-agrotoxicos>.
} 
por habitante. O cálculo per capita, feito a partir do total de produtos defensivos comprados por proprietários de terras do estado, é o maior do país e supera em mais de $1.000 \%$ o índice nacional, que é de 3,9 quilos por brasileiro. O ano de referência para os dados citados é 2009". Catástrofes como a que atingiu Lucas do Rio Verde (MT), onde a pulverização aérea de pesticidas afetou gravemente a cidade em 2006, poderão se reproduzir com maior frequência caso esse método não seja proibido no Brasil, tal qual ocorreu em vários outros países.

Segundo o Instituto Brasileiro de Geografia e Estatística (IBGE), o uso de agrotóxicos e fertilizantes já é a segunda causa de contaminação da água no país (Werneck, 2005). Puxados pela expansão das monoculturas de grãos e da cana-de-açúcar, acelerada pelo consumo de etanol como agrocombustível, pelos desertos verdes dos eucaliptos para celulose ou carvão vegetal, ou, ainda, pela fruticultura, os agrotóxicos fazem parte do modelo de agricultura hegemônica no Brasil, que degrada o solo, é químico-dependente e explora e expulsa trabalhadores do campo.

Apesar da crise mundial, há grande expectativa de crescimento do setor da mineração. Segundo $O$ Estado de S. Paulo, o minério de ferro tem sido a grande estrela, mas são previstos investimentos também vultosos em níquel (US\$ 6,718 bilhões), alumina (US\$ 1 bilhão), bauxita (US\$ 987 milhões) e, em menor grau, fosfato, cobre e ouro em áreas já pesquisadas (A expansão, 2010).

Não pode ser esquecida a exploração do amianto, cuja promessa de banimento feita pelo Partido dos Trabalhadores (PT) antes de chegar ao governo não se concretizou. Há ainda a mineração do urânio, em Caetité, Bahia, e em Santa Quitéria, Ceará, ambas denunciadas pela Relatoria em Direito Humano ao Meio Ambiente da Plataforma Dhesca Brasil. Às populações do Pará, Maranhão e Minas Gerais, principais atingidas pelos empreendimentos de mineração, acrescentam-se outras, de outros estados, sobretudo se articularmos com a mineração o conjunto da cadeia produtiva das commodities metálicas, como o ferro-aço ou a bauxita-alumínio.

Se a luta mundial contra o amianto faz vislumbrar o fim da exploração da mineração, a do urânio pode se perpetuar. Os graves problemas e os conflitos causados pela exploração do petróleo e seu beneficiamento vão sem dúvida se multiplicar com o pré-sal e as novas áreas pesquisadas, projetando um cenário em que inúmeros riscos se agravarão, como os desastres ambientais em mar ou terra, a poluição atmosférica produzida por fábrica e veículos, ou mesmo a dificuldade do Brasil em contribuir para a redução dos gases de efeito estufa. 
Embora o Programa de Aceleração do Crescimento (PAC) sofra atrasos, ele continua, em sintonia com a Iniciativa de Integração da Infraestrutura Regional Sul-Americana (IIRSA), um grande vetor de destruição ambiental e de pressão sobre as populações que encontra no seu caminho e que, no caso da IIRSA, atinge também países vizinhos. Segundo Elder Andrade de Paula (2011), professor da Universidade Federal do Acre,

O que estamos vendo [na Amazônia] é uma aceleração monumental da insustentabilidade. Está acontecendo (...) um processo avassalador de destruição que pode ser comparado ao período da ditadura militar da década de 1970. Todos os esforços realizados pelo governo em nível federal ou estadual são para transformar a Amazônia em uma base de expansão desse modelo primário exportador. As repercussões para as populações que vivem em tais territórios são enormes, uma vez que eles estão sendo avassalados de formas diversas por empresas madeireiras e mineradoras. As populações camponesas, os seringueiros, os ribeirinhos, todos os assentados, todos os que vivem da terra e na terra estão sendo afetados por essas grandes obras.

A pujança da agroexportação e a força política dos setores sociais que a encabeçam fazem antever tempos difíceis para quilombolas, comunidades tradicionais e, em particular, para os povos indígenas.

\section{A Conjuntura Política}

Em audiência, concedida a dom Erwin Klautner, bispo de Altamira, em julho de 2009, pelo então presidente Luiz Inácio Lula da Silva, sobre o projeto da usina hidroelétrica de Belo Monte, um alto funcionário da área de energia comentou que alguns milhares de pessoas não podiam se sobrepor aos imperativos do desenvolvimento. ${ }^{3}$ Ele expressava em voz alta o que os adeptos do 'crescimento a qualquer preço' não teriam coragem de confessar. Por interesse, cinismo, convicção ou tudo junto, muitos empresários, políticos, autoridades do Poder Executivo ou mesmo técnicos e cientistas pouco críticos em relação ao establishment acreditam (ou dizem acreditar) que o sacrifício dessa minoria realmente significa vida melhor para a maioria. Mas qual maioria? E como estabelecer os critérios dessa equação, que compara benefícios a vidas, culturas e ecossistemas destruídos, além de se esquecer de nela contabilizar os trágicos cenários futuros?

Não há por que duvidar da sinceridade da presidente Dilma Rousseff quando declara que sua prioridade é a erradicação da pobreza, até porque

\footnotetext{
${ }^{3}$ Relato pessoal a um dos autores durante o Encontro da Associação Nacional de Pós-Graduação e Pesquisa em Ciências Sociais (Anpocs) em Caxambu, em outubro 2011.
} 
os indicadores sociais efetivamente mostram melhoria nesse setor. Segundo Maria Luiza Rolim (2011),

De 2002 a 2011, pelo menos 4,2 milhões de pessoas saíram da situação de baixa renda (até meio salário mínimo mensal per capita), o que equivale a $24,8 \%$ de queda nesse segmento: de 17 milhões de pessoas em 2002 para 12,8 milhões em julho de 2011. A diminuição, contudo, ocorreu de forma distinta nas seis regiões metropolitanas do país e foi impactada pela desaceleração econômica de 2011.

Se raciocinarmos de forma meramente estatística, a expulsão de algumas dezenas de milhares de pessoas das suas terras e a saúde destruída de outras tantas não deveriam pesar. Entretanto, o acúmulo das injustiças cometidas em nome do 'crescimentismo' sinaliza um sério enfraquecimento da democracia, quando importantes minorias se veem excluídas da cidadania, das quais a maior parte, além de tudo, é marcada pelo estigma do racismo.

Algumas características atuais da ação pública, tanto dos Executivos quanto dos Legislativos e do Judiciário, preocupam. Na maioria dos casos, as prioridades parecem ser as mesmas: crescimento antes de tudo. Isso com muita frequência leva os agentes públicos a terem comportamentos discriminatórios e arrogantes diante das populações, principalmente nos casos dos empreendimentos nos quais alguma instância de governo é mandante e/ou executora. A pouca atenção dada por parte do Estudo de Impacto Ambiental/Relatório de Impacto Ambiental (EIA/Rima) aos atingidos por empreendimentos, projetos e obras já era objeto de questionamento e mesmo de propostas alternativas, como a Avaliação de Equidade Ambiental (Fase \& Ettern/Ippur/UFRJ, 2011), tanto da parte das comunidades, como das organizações que as apoiam. No caso específico dos povos indígenas e das comunidades tradicionais, o direito à consulta prévia e informada, teoricamente garantido por meio da assinatura do Brasil na Convenção 169 da Organização Internacional do Trabalho, continua sendo desrespeitado.

A fragilização da legislação e das normas socioambientais e de saúde, assim como a criação de regras que parecem diretamente inspiradas por interesses privados, seja na área dos transgênicos, do uso de agrotóxicos, do licenciamento ambiental ou, agora, do Código de Mineração, preocupam sobremaneira os que buscam um futuro sustentável e justo. O poder que essas forças - em particular o agronegócio, por meio da bancada ruralista - detêm no Congresso não permite vislumbrar qualquer mudança substancial dessas tendências no que se refere aos direitos humanos. Ao contrário, o que se vê é um número cada vez maior de propostas de emendas constitucionais (PECs) e projetos de lei (PLPs) voltados exatamente para retirar da Constituição de 1988 os direitos conquistados por povos indígenas e quilombolas. 
O governo federal vive uma dupla contradição, entre um setor político historicamente comprometido com mudanças sociais e outros historicamente fisiológicos; entre a sua vontade de eliminar a pobreza, de garantir a voz da sociedade civil e de reforçar as solidariedades Sul-Sul, de um lado, e, do outro, a profunda vontade de inserir o país na economia mundial globalizada em sintonia com a sua visão desenvolvimentista. Tal visão se alinha com poderosos setores econômicos responsáveis pela exportação de commodities rurais (agronegócio) e metálicas (como as mineradoras e siderúrgicas), consideradas estratégicas para o equilíbrio fiscal dentro de uma visão macroeconômica que desconsidera as inúmeras externalidades negativas e injustiças produzidas por tais setores. Nesse sentido, a democracia está sendo fragilizada e mesmo colocada em perigo pela subordinação dos Estados ao mercado mundial.

Três pesquisadores da área de sistemas complexos do Instituto Federal de Tecnologia de Lausanne, na Suíça, mostraram as interconexões entre 1.318 empresas transnacionais que formam o núcleo da economia mundial. Refinando sua pesquisa, identificaram 147 empresas intimamente interrelacionadas que controlam $40 \%$ da riqueza total daquele primeiro núcleo central de empresas (Vitali, Glattfelder \& Battiston, 2011). Coincidentemente, na revista Época, o professor de Direito Constitucional na Universidade do Texas, Philip Bobbitt (2011), apresentado como "consultor de quase todos os presidentes dos Estados Unidos desde 1970" e defensor da tese de que o Estado-nação será substituído pelo Estado-mercado, informa que "a mudança que ocorre de Estados-nação para Estados-mercado não é uma questão de vontade: é inevitável".

Não se pode esquecer de que o Estado-nação foi o instrumento que facilitou o surgimento do capitalismo industrial, mas foi nele que o movimento operário obteve conquistas sociais importantes, que permitiram, no mundo ocidental, o estabelecimento de Estados de Bem-Estar Social e o reconhecimento quase universal dos direitos humanos. Portanto, nenhum governo ou partido pode se esconder atrás de um suposto determinismo histórico. Que interesses e bases éticas tem esse Estado-mercado que tende a se expandir para o conjunto das esferas não só de produção econômica, mas de atividades classicamente assumidas pelo Estado-nação, como a seguridade social, a defesa da saúde e do meio ambiente, a proteção social, a educação, a cultura e a produção científica? 


\section{Dilema Ético-Filosófico}

O Estado republicano e democrático não é mero espelho da sociedade; na verdade ele reflete as próprias assimetrias e relações de poder existentes. Sofre, portanto, influências por parte dos grupos sociais que detêm o poder econômico e político e dominam os meios de comunicação de massa. A chamada 'opinião pública', que sistematicamente repercute, amplifica e legitima a voz desses grupos dominantes, é entendida, sem maior questionamento, como a expressão da sociedade em geral. Um Estado de Direito deve assegurar que os interesses diferentes e até contraditórios das classes e dos grupos e setores sociais possam coexistir e, ainda, deve garantir a cidadania dos setores marginalizados e fragilizados. Diante de uma economia capitalista que não coloca outra alternativa ao desenvolvimento senão ela própria e que conduz os Estados a um inevitável enredamento, de bom ou mau grado, nas teias do mercado global, qual espaço de questionamento sobra à sociedade? E de que sociedade se está falando? Que vozes e interesses estão presentes nesse debate? Que futuro se está construindo?

As principais empresas brasileiras e multinacionais atuantes no país se apresentam como atores sociais. Um levantamento na web mostra que quase todas desenvolvem - diretamente ou em organizações não governamentais (ONGs) ou fundações que elas comandam - programas sociais e/ou ambientais, frequentemente em nome de uma 'responsabilidade corporativa social e ambiental' que representa importante estratégia de marketing na atualidade. Mais amplamente, o setor empresarial, ao afirmar que a solução da crise climática passa pelo maior desenvolvimento da economia, adjetivada de 'verde', apresenta-se como ator central no debate do futuro. $\mathrm{O}$ fracasso total das políticas de redução das emissões de gases de efeito-estufa é unilateralmente debitado na conta dos governos ou do comportamento ainda 'inconsciente' de consumidores, esquecendo-se comodamente de que são as grandes corporações financeiras e produtivas as responsáveis pela continuação do modelo de produção e de consumo. Aqui está uma elite que, direta ou indiretamente, com seu poder econômico, exerce a hegemonia intelectual sobre grande parte das sociedades humanas e instituições na atualidade.

Em diferentes frentes de pesquisa e/ou de assessoria a grupos de atingidos, o que se observa é a pouca atenção, a incompreensão e mesmo a condenação que tais grupos recebem do seu entorno por parte de setores que acreditam se beneficiar dos empreendimentos que geram as injustiças. É como se o crescimento, que representa a possibilidade de se ter acesso a um consumo 
sempre maior, fosse a única perspectiva de futuro coletivo e individual que se apresenta à sociedade. Para muitos defensores desse modelo, seu sucesso é indicado pela ascensão de novos setores da classe média, aos quais Jessé Souza (2010a) chama de 'batalhadores'. Comenta o professor em entrevista:

Sem a socialização anterior de lutas operárias organizadas, disponíveis para aprender trabalhos de qualquer natureza e dispostas a se submeter a praticamente todo tipo de superexploração da mão de obra, essa nova classe social logrou ascender a novos patamares de consumo às custas de extraordinário esforço e sacrifício pessoal. Essa parece ser a 'vantagem comparativa' real dos países emergentes. (Souza, 2010b)

Nas grandes cidades, à diferença do proletário que logrou minorar a superexploração em decorrência da solidariedade expressa por quase dois séculos de lutas sociais, o batalhador de hoje é um individuo só, competindo na vida real como se participasse de um reality show, em busca do sucesso representado pela entrada no mercado do consumo. Cada um por si. E o 'cada um por si' retroalimenta o mercado, como se dissesse que está no bom caminho e que pode acelerar sem se preocupar demais com os direitos e o meio ambiente, ao mesmo tempo que conforta o poder público na sua boa consciência, como se dissesse que o povo o acompanha. Portanto, o 'sucesso' representado por uma classe em ascensão, sem capacidade crítica para compreender a realidade ou construir alternativas políticas em um mundo crescentemente em crise, precisa de outros ingredientes para transformar a sociedade em direção a outros futuros possíveis, mais sustentáveis, justos e solidários.

Zygmunt Bauman (2011: 195) comenta que "o consumidor é um inimigo do cidadão. Por toda a parte 'desenvolvida' e rica do planeta, abundam sinais (...) de que as pessoas viram as costas para a política". Seriam tempos sombrios que se anunciariam, se a história, os movimentos do Oriente Médio, os indignados da Europa e dos Estados Unidos e outros exemplos bem mais próximos não nos ensinassem que a humanidade ainda está construindo o seu futuro, e este parece longe de seu fim.

\section{Conclusão}

Confrontados por um poder econômico esmagador, pelas contradições do Estado e por representantes dos Legislativos, dos Executivos e dos Judiciários, muitos dos quais mais parecem verdugos que defensores dos seus direitos, os atingidos nos conflitos não são, entretanto, vítimas que se deixam conduzir ao sacrifício sem protestar ou construir alternativas. Na verdade, vêm colocando 
em suas práticas cotidianas as sementes de uma sociedade bem diferente daquela que o mercado, muitos políticos, burocratas, operadores do Direito e mesmo cientistas insistem em defender como a única possível.

Ao poder econômico, respondem que também produzem, com uma outra economia, solidária, que respeita as pessoas, a vida e a natureza; ao poder público, demonstram que seu clamor é um magnífico reconhecimento da importância do Estado de Direito; aos indiferentes fechados no seu egoísmo, lembram que nenhuma sociedade se sustenta e se mantém humana sem se basear na solidariedade, na responsável busca de liberdade e felicidade, mas também no respeito às diferenças, à diversidade e à natureza, celebrada na nova constituição de nosso vizinho Equador em seu preâmbulo: "la Pacha Mama, de la que somos parte y que es vital para nuestra existencia".

Como sugere Boaventura de Souza Santos (2006), em seu livro A Gramática do Tempo: para uma nova cultura política, tal reconhecimento pressupõe novas formas de se produzir conhecimentos, presentes na ideia de uma ecologia dos saberes e de uma nova sociologia da emergência, as quais têm como desafio central traduzir as novas condições de pluralidades políticas e epistemológicas na reinvenção solidária de um mundo em transformação.

Felizmente, os atingidos não estão sozinhos. Aliás, nenhum dos que lutam por sociedades justas, democráticas e sustentáveis está sozinho. Às milhares de famílias envolvidas nos conflitos (às quais poderíamos acrescentar milhões de outras em inúmeros conflitos que não estão ainda presentes em nosso mapa e análises), soma-se um número incalculável de pessoas e entidades que se solidarizam com elas de muitas maneiras. E esses números crescem à medida que as redes de solidariedade articulam os vários lugares e pessoas, o local ao global e vice-versa, conformando outras possibilidades contra-hegemônicas de globalização.

Apesar de serem os mais atingidos no mapa, os povos indígenas são um magnífico exemplo do que estamos falando. Quase inteiramente dizimados por ocasião da abertura da BR-174 (Manaus-Boa Vista), obra realizada na época da ditadura militar, em 2003 os Waimiri Atroari comemoraram o nascimento de Iawyraky, o milésimo indivíduo de uma etnia que já havia sido centenas de milhares de vezes maior. No dia 4 de novembro de 2011, apenas oito anos depois, eles festejaram o nascimento do $1.500^{\circ}$ : haviam recuperado $50 \%$ de sua gente, e agora davam as boas-vindas a uma menina, Ketamyna (Dantas, 2011). Se no Mato Grosso do Sul, como vimos, os povos indígenas parecem ser usados ano após ano para garantir ao estado a liderança nas estatísticas dos suicídios e assassinatos, em outros estados eles recuperam, junto com sua cultura, suas tradições e seu amor à natureza e à vida. 
Talvez mais importante ainda, entretanto, seja um fato que vem se repetindo Brasil afora e que só pode ser motivo de esperança, além de uma lição para todos nós: as alianças que se formam, principalmente no campo, e que por vezes se alastram pelas cidades, por meio da solidariedade aos movimentos sociais e entidades tipicamente urbanos. Se tomarmos apenas os últimos meses de 2011, o que vemos são exemplos de ajuda e de cooperação na luta que só podem ser classificados de comoventes.

No norte de Minas, vazanteiros e quilombolas se uniram, nos últimos dias de julho, e, caminhando madrugada adentro, fizeram a 'retomada' do que era seu de direito, demarcando eles próprios a Reserva de Desenvolvimento Sustentável de Pau Preto, cujo nome seria, semanas mais tarde, mudado para Arraial do Meio. O território que ocuparam havia sido em parte invadido por grileiros e fazendeiros. E o próprio Estado se incumbira de tomar o restante, principalmente a parte pertencente ao Quilombo da Lapinha, transformando-o numa área de proteção permanente. Na reunião em que a comunidade recebeu a defensora pública da área do São Francisco e o coordenador do Instituto Estadual de Florestas, já no final de 2011, foi o próprio coordenador quem reconheceu a arbitrariedade, como pode ser conferido em vídeo disponível na Internet: "Nós somos invasores de uma terra que pertence à comunidade, eu me envergonho de dizer" (Combate Racismo Ambiental, 2011).

Na gravação, antes da chegada de ambos, vazanteiros e quilombolas contaram suas histórias sobre a retomada. Mas encerraram sua manifestação num brado coletivo a algo que, numa visão individualista, não lhes dizia respeito: “Nossa homenagem a Brejo dos Crioulos!". Era a forma de mostrar que estavam juntos com outra comunidade quilombola de Minas sob ameaças de violência.

O exemplo de solidariedade não termina aí. O vídeo que documenta esse encontro com as autoridades, assim como outros, mostrando desde a noite anterior até a saída para a retomada, estão disponíveis em um $b \log 4$ organizado com a ajuda de uma ONG ligada à agricultura familiar: o Centro de Agricultura Alternativa (CAA) do norte de Minas. Esse centro igualmente é parceiro dos geraizeiros - com os quais estava, na mesma época, organizando duas audiências públicas, realizadas na última semana de novembro de 2011, para a conquista de uma reserva extrativista dos camponeses tradicionais e do povo indígena Xakriabá, em luta pelo fim da demarcação de suas terras.

\footnotetext{
${ }^{4}$ Vazanteiros em Movimento, disponível em: <www.vazanteirosemmovimento.wordpress.com>.
} 
Outro belo exemplo que merece ser citado, também em novembro de 2011, aconteceu na Paraíba. Cerca de 150 índios da etnia Tabajara realizaram uma ação de retomada de suas terras na região do litoral sul do estado. Reivindicaram a demarcação de aproximadamente 10 mil hectares entre os municípios de Conde, Alhandra e Pitimbu, ocupados por um grupo empresarial para o monocultivo de cana-de-açúcar e assentamentos. E o importante é justamente que os trabalhadores rurais do assentamento Mucatu estiveram presentes na ação, prestando apoio e solidariedade à causa indígena, embora o Mucatu esteja localizado em área que também é reivindicada como território Tabajara.

Presente durante a retomada, Tania Souza, da coordenação regional da Comissão Pastoral da Terra de Pernambuco (CPT/PE), emocionou-se duplamente: "este é um marco para a luta pela terra e território na Paraíba. Um momento novo em que os verdadeiros donos da terra, o povo indígena, fazem retomada de sua terra, seu território, para ter vida digna no campo". E foi além, sensível exatamente ao que queremos aqui destacar: "é muito significativa a aliança entre os povos camponeses, indígenas, quilombolas, assentados e sem-terra para a luta pela terra e em defesa dos territórios destes povos" (CPT/PE, 2012).

Outro fato marcaria o episódio: o cacique Tabajara Edinaldo, na ocasião, pronunciou uma frase que desde então passou a ser repetida, pela sua força, embora raramente seja atribuída a ele: "Arrancaram nossas folhas, quebraram nossos galhos, cortaram nosso tronco, mas esqueceram nossas raízes" (CPT/PE, 2012).

Para nós, das cidades, das entidades e academias, talvez seja preciso cada vez mais aprender a ouvir e a ouvir aprendendo com aqueles que, para muitos, não passam de ignorantes ou de 'entraves ao desenvolvimento'. É necessário, igualmente, ajudar a visibilizá-los e, se necessário, facilitar as suas articulações, partindo de uma perspectiva de construção de diálogos e de estratégias que explicitem também a relação capital/racismo na reprodução das injustiças ambientais.

Com o projeto do Mapa de Conflitos, buscamos realizar o que se propôs no Encontro Nacional de Diálogos e Convergências: agroecologia, saúde e justiça ambiental, soberania alimentar, economia solidária e feminismo, realizado em outubro de 2011, em Salvador, na parte final de sua carta política:

Uma das linhas estratégicas para a promoção dos diálogos e convergências é a produção e disseminação de conhecimento sobre as trajetórias históricas de disputas territoriais e suas atuais manifestações. Nesse sentido, as alianças com o 
mundo acadêmico devem ser reforçadas também como parte de uma estratégia de reorientação das instituições do Estado, no sentido destas reforçarem as lutas pela justiça social e ambiental. Estimulamos a elaboração e uso de mapas que expressem as diferentes dimensões das lutas territoriais pelos seus protagonistas como uma estratégia de visibilização e articulação entre nossas redes e movimentos. (Encontro Nacional de Diálogos e Convergências, 2011)

Referindo-se à necessidade de visibilizar nos movimentos feministas a presença das mulheres negras, Sueli Carneiro (2003) afirmou que era importante "enegrecer o feminismo". Encerramos este capítulo adaptando suas palavras: a luta por justiça ambiental no Brasil só tem a ganhar e a avançar, em força e em coerência, à medida que todos aceitarmos a importância de "enegrecer e indianizar o ambientalismo", potencializando processos transculturais e políticas para a transformação. A luta de resistência de uma minoria e a persistência (ainda que contra-hegemônica e invisível) da cotidiana reivenção de alternativas, em diferentes espaços, podem ser o anúncio de uma sociedade à busca de reconstrução dos ideais perdidos. 


\section{Referências}

A EXPANSÃO da mineração. Estadão. São Paulo, 7 maio 2010. Disponível em: <www.estadao. com.br/noticias/impresso,a-expansao-da-mineracao,548202,0.htm>. Acesso em: 22 jul. 2013.

AGÊNCIA ESTADO. Agroquímicos: Brasil deve se tornar principal mercado em dois anos. Rio de Janeiro, 2010. Disponível em: <www.economia.ig.com.br/empresas/agronegocio/ agroquimicos-brasil-deve-se-tornar-principal-mercado-em-dois-anos/n1237757626020.html>. Acesso em: 22 jul. 2013.

ANDRADE DE PAULA, E. Amazônia: desenvolvimento insustentável e a busca do outro modelo. São Leopoldo, 2011. Entrevista. Disponível em: <www.ihu.unisinos.br/entrevistas/500493amazonia-desenvolvimento-insustentavel-e-a-busca-de-outro-modelo-entrevista-especial-comelder-andrade-de-paula>. Acesso em: 22 jul. 2013.

BAUMAN, Z. A Ética é Possível num Mundo de Consumidores? Rio de Janeiro: Zahar, 2011.

BOBBITT, P. O estado nacional não atende a sociedade. Entrevista. Época. São Paulo, 10 out. 2011. Disponível em: <www.revistaepoca.globo.com/ideias/noticia/2011/10/philip-bobbitt-oestado-nacional-nao-atende-sociedade.html>. Acesso em: 22 jul. 2013.

BRASIL. Ministério de Minas e Energia. Empresa de Pesquisa Energética. Plano Decenal de Expansão de Energia 2019. Brasília: Ministério de Minas e Energia, Empresa de Pesquisa Energética, 2010. Disponível em: <www.mme.gov.br/mme/galerias/arquivos/noticias/2010/ PDE2019_03Maio2010.pdf >. Acesso em: 14 nov. 2011.

CARNEIRO, S. Enegrecer o feminismo: a situação da mulher negra na América Latina a partir de uma perspectiva de gênero. In: ASHOKA EMPREENDIMENTOS SOCIAIS \& TAKANO CIDADANIA (Orgs.). Racismos Contemporâneos. Rio de Janeiro: Takano, 2003.

CARSON, R. Primavera Silenciosa. São Paulo: Gaia, 2010.

COMBATE RACISMO AMBIENTAL. Vazanteiros em movimento: reunião com MP e o IEF é uma bela aula de como deveriam ser as relações com as comunidades. Rio de Janeiro, 2011. Disponível em:<www.racismoambiental.net.br/2011/11/vazanteiros-em-movimento-avaliacaoe-encontro-com-a-promotoria-publica-e-o-ief>. Acesso em: 15 dez. 2012.

COMISSÃO MUNDIAL SOBRE MEIO AMBIENTE E DESENVOLVIMENTO. Nosso Futuro Comum. Rio de Janeiro: Editora FGV, 1991.

COMISSÃO PASTORAL DA TERRA DE PERNAMBUCO (CPT/PE). Comissão Nacional de Combate à Violência no Campo visita conflito agrário na Paraíba. Disponível em: <www. racismoambiental.net.br/2012/02/comissao-nacional-de-combate-a-violencia-no-campo-visitaconflito-agrario-na-paraiba-15-02-2012>. Acesso em: 15 dez. 2012.

DANTAS, G. S. Nasce índio de número 1.500 da etnia waimiri-atroari. A Crítica. Manaus, 14 nov. 2011. Disponível em: <http://acritica.uol.com.br/amazonia/Nasce-indio-etnia-WaimiriAtroari_0_590940948.html>. Acesso em: 15 dez. 2012.

ENCONTRO NACIONAL DE DIÁlogOS E CONVERGÊNCIAS. Carta Política do Encontro Nacional de Diálogos e Convergências. Salvador, 2011. Disponível em: <www. dialogoseconvergencias.org/noticias/carta-politica-do-encontro-nacional-de-dialogos-econvergencias>. Acesso em: 20 mar. 2012.

FEDERAÇÃO DE ÓRGÃOS PARA A ASSISTÊNCIA SOCIAL E EDUCACIONAL \& LABORATÓRIO ESTADO, TRABALHO TERRITÓRIO E NATUREZA DO INSTITUTO DE PESQUISA E PLANEJAMENTO URBANO E REGIONAL DA UNIVERSIDADE FEDERAL DO RIO DE JANEIRO (FASE \& ETTERN/IPPUR/UFRJ). Relatório-síntese: projeto avaliação de equidade ambiental como instrumento de democratização dos procedimentos de avaliação de impacto de projetos de desenvolvimento. Rio de Janeiro: Fase, Ettern/Ippur, 2011. 
FÓRUM DIREITOS HUMANOS E DA TERRA MATO GROSSO. Carta por um Mato Grosso

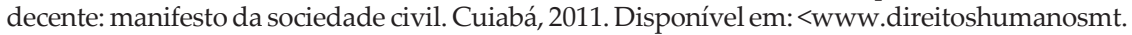
blogspot.com>. Acesso em: 22 jul. 2013.

INSTITUTO BRASILEIRO DE GEOGRAFIA E ESTATÍSTICA (IBGE). Indicadores de Desenvolvimento Sustentável do Instituto Brasileiro de Geografia e Estatística: IDS 2012. Rio de Janeiro: IBGE, 2012. Disponível em: <www.ibge.gov.br/home/geociencias/ recursosnaturais/ids/default_2012.shtm>. Acesso em: 26 jul. 2013.

ROLIM, M. L. Brasil já só tem $28 \%$ de pobres. Expresso. 5 out. 2011. Disponível em: <www. aeiou.expresso.pt/brasil-ja-so-tem-28-de-pobres=f678118>. Acesso em: 22 jul. 2013.

SANTOS, B. S. A Gramática do Tempo: para uma nova cultura política. São Paulo: Cortez, 2006.

SOUZA, J. Os Batalhadores Brasileiros: nova classe média ou nova classe trabalhadora? Belo Horizonte: Editora UFMG, 2010a.

SOUZA, J. Jessé Souza traça perfil da nova classe trabalhadora brasileira. Entrevista. Boletim UFMG. Belo Horizonte, 17 dez. 2010b. Disponível em:<www.ufmg.br/online/arquivos/017683. shtml>. Acesso em: 22 jul. 2013.

VITALI, S., GLATTFELDER, J. B. \& BATTISTON, S. The network of global corporate control. Zurich, 2011. Disponível em: <www.arxiv.org/pdf/1107.5728v2.pdf>. Acesso em: 22 jul. 2013.

VITALI, F. et al. Dossiê Abrasco: um alerta sobre os impactos dos agrotóxicos na saúde. Rio de Janeiro: Abrasco, 2012. Disponível em: <www.abrasco.org.br/UserFiles/File/ ABRASCODIVULGA/2012/DossieAGT.pdf>. Acesso em: 22 jul. 2013.

WERNECK, F. Agrotóxico é $2^{\underline{a}}$ causa de contaminação da água no país. O Estadão On-Line. São Paulo, 13 maio 2005. Disponível em: <www.estadao.com.br/arquivo/vidae/2005/ not20050513p473.htm>. Acesso em: 20 maio 2011. 


\section{Anexo}

\section{Formulário FormSUS}

Formulário | Resultado | Busca Ficha | Aftera Ficha | Imprimir Formulário Levantamento de dados para o Mapa de confilitos envolvendo injustiça ambiental e saúde no Brasil Este é um formulário fechado, restrito aos pesquisadores do projeto "Mapa de conflitos envolvendo injustiça ambiental e saúde no Brasil".

Só podem ter acesso a ele usuários e gestores ligados diretamente ao projeto.

As decisões quanto à abertura das fichas e a oestão, em si, do formulário e de seus campos, assim como dos acessos a eles, cabe exdusivamente a Tania Pacheco, coordenadora-executiva do projeto.

* Preenchimento Obrigatório

Clique aqui em caso de dúvidas relativas a este formulário.

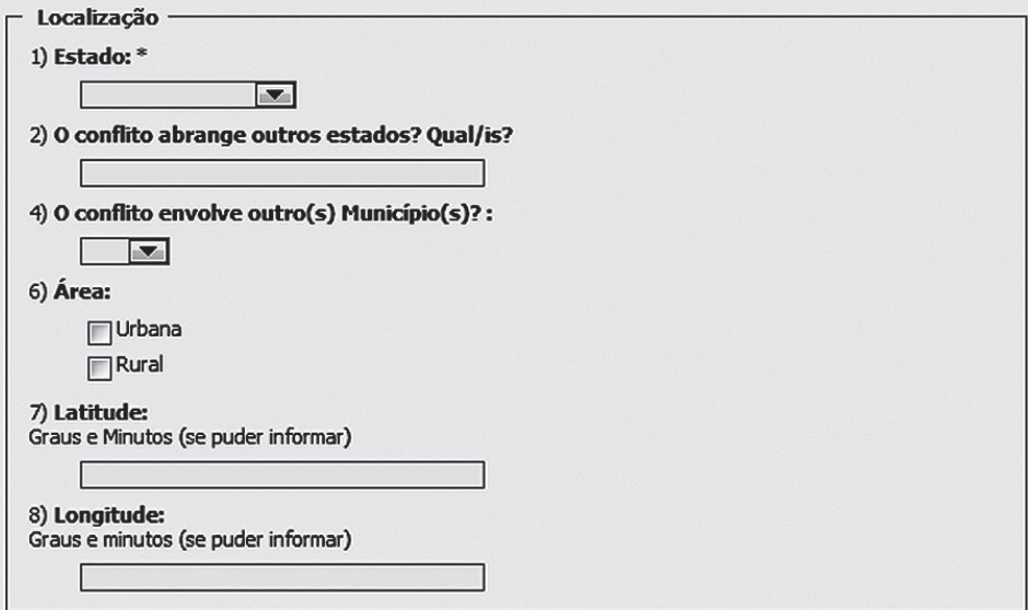

\section{- População Atingida}

9) Qual o tipo de população atingida? *

(mais de uma opção pode ser escolhida)

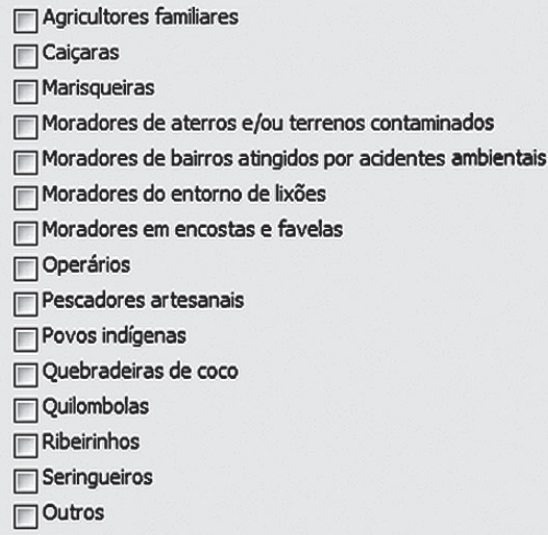

${ }^{1}$ Disponível em: $<$ http://formsus.datasus.gov.br/site/formulario.php?id_aplicacao=2220 $>$. Acesso em: 2 maio 2013. 
11) Aproximadamente, quantas pessoas foram ou estão sendo atingidas?

12) Majoritariamente, as pessoas são:

$\nabla$

Tipologia do conflito

13) Quais os impactos e riscos ambientais? *

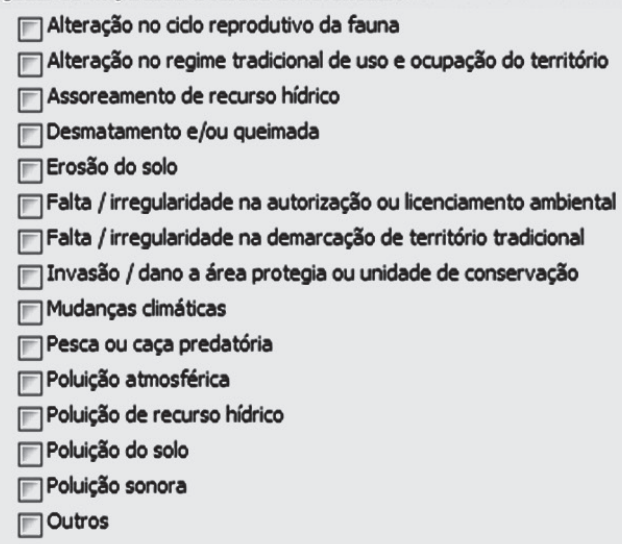

15) Quais os problemas ou riscos à saúde envolvidos no conflito? *

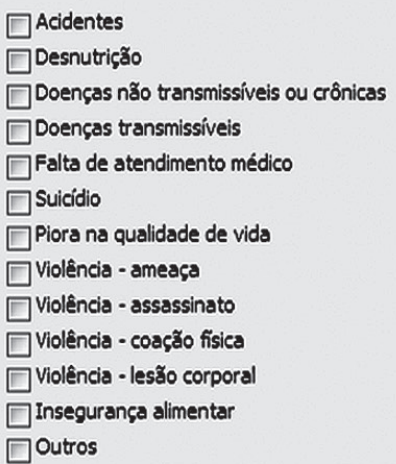

16) Especifique $0 / s$ risco/s ou dano/s à saúde:

17) Quais os processos produtivos? : *

(mais de uma opşão pode ser escolhida)

$\square$ Atividades pesqueiras e carcinicultura
$\square$ Madeireiras
$\square$ Monocultura
$\square$ Indústria química e do petróleo
$\square$ Mineração, garimpos e siderurgia
$\square$ Barragens e hidrelétricas
$\square$ Hidrovias, rodovias, gasodutos
$\square$ Energia e radiaçōes nucleares




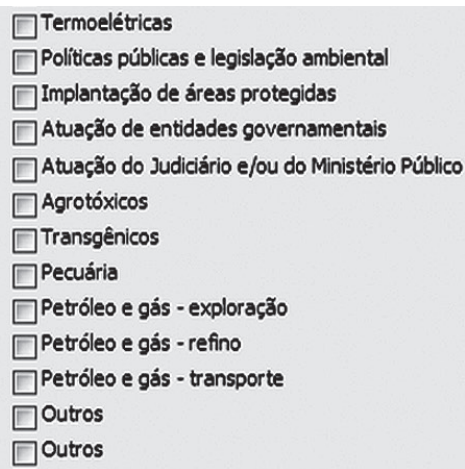

19) Quais os responsáveis pelo conflito? *

20) Quais os parceiros e apoiadores dos atingidos? (mais de uma opção pode ser escolhida)

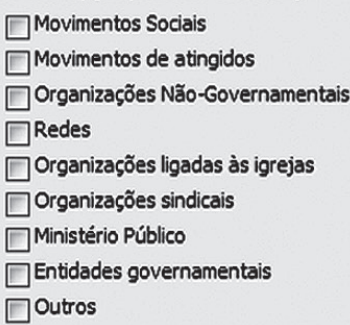

\section{- Descrição do conflito}

22) Sintese do conflito: *

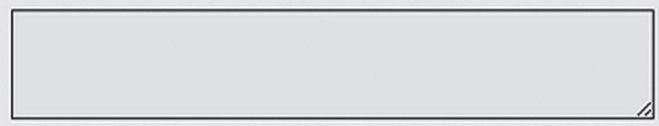

23) Contexto ampliado: *

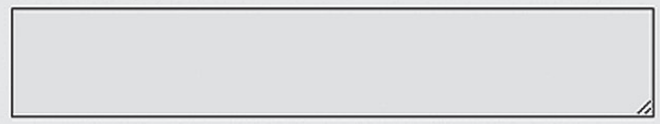

24) Cronologia: *

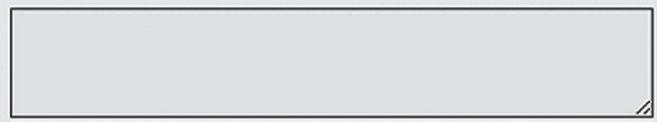

25) Perspectivas e vulnerabilidades:

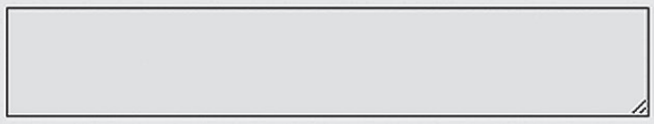


26) Fontes sobre 0 assunto: *

(depoimentos, artigos, jornais, teses, livros etc)

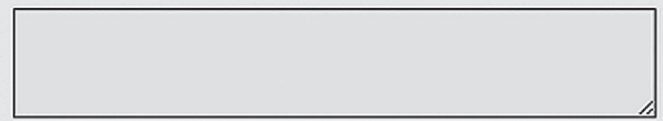

- Responsável pela informação

27) Nome: *

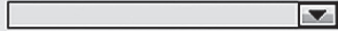

28) E-mail:

29) Telefone:

30) Instituição:

\section{Gravar}

Atenção: Ao gravar aguarde a tela de confirmação. Somente se aparecer a mensagem de confirmação seus dados terão sido gravados.

Clique aqui em caso de dúvidas relativas a este formulário.

Página 1 de 1

Nota: A numeração do formulário aqui apresentada não aparece sequencialmente porque algumas perguntas são opcionais e dependem da seleção de determinados campos durante o preenchimento. 
Formato: $16 \times 23 \mathrm{~cm}$

Tipologia: Palatino Linotype, Myriad e American Typewriter (miolo/capa)

Papel: Polén Bold 70g/m2 (miolo)

Cartão Supremo $250 \mathrm{~g} / \mathrm{m} 2$ (capa)

CTP, Impressão e acabamento: Imos Gráfica e Editora Ltda.

Rio de Janeiro, novembro de 2013.

Não encontrando nossos títulos em livrarias,

contactar a Editora Fiocruz:

Av. Brasil, 4036 - térreo - Manguinhos

21040-361 - Rio de Janeiro - RJ

Telefones: (21) 3882-9039 e 3882-9041

Telefax: (21) 3882-9006

editora@fiocruz.br

www.fiocruz.br/editora 